ESCOLA POLITÉCNICA DA UNIVERSIDADE DE SÃO PAULO

MARILENA MARTINS PAMBOUKIAN

ESTUDO DA ATIVIDADE RESPIRATÓRIA DE LINHAGENS

SELVAGENS E TRANSFECTADAS DE CÉLULAS DE INSETOS ATRAVÉS DE CULTIVOS EM BIORREATORES 
ESCOLA POLITÉCNICA DA UNIVERSIDADE DE SÃO PAULO

MARILENA MARTINS PAMBOUKIAN

\section{ESTUDO DA ATIVIDADE RESPIRATÓRIA DE LINHAGENS SELVAGENS E TRANSFECTADAS DE CÉLULAS DE INSETOS ATRAVÉS DE CULTIVOS EM BIORREATORES}

\footnotetext{
Dissertação apresentada à Escola Politécnica da Universidade São Paulo para obtenção do Título de Mestre em Engenharia.
} 
ESCOLA POLITÉCNICA DA UNIVERSIDADE DE SÃO PAULO

MARILENA MARTINS PAMBOUKIAN

\title{
ESTUDO DA ATIVIDADE RESPIRATÓRIA DE LINHAGENS SELVAGENS E TRANSFECTADAS DE CÉLULAS DE INSETOS ATRAVÉS DE CULTIVOS EM BIORREATORES
}

\author{
Dissertação apresentada à Escola \\ Politécnica da Universidade São Paulo \\ para obtenção do Título de Mestre em \\ Engenharia. \\ Área de Concentração: \\ Engenharia Química \\ Orientador: \\ Prof. Dr. Aldo Tonso
}


PAMBOUKIAN, Marilena Martins. Estudo da atividade respiratória de linhagens selvagens e transfectadas de células de insetos através de cultivos em biorreatores. São Paulo. 2007. (Mestrado) Escola Politécnica. Universidade de São Paulo, São Paulo, 2007.

\section{ERRATA}

\begin{tabular}{|c|c|c|c|}
\hline PÁGINA & LINHA & ONDE SE LÊ & LEIA-SE \\
\hline 8 & $1^{a}$ & um parâmetro & uma variável \\
\hline 9 & $1^{a}$ & parameter & variable \\
\hline 25 & $13^{a}$ & insetos. & $\begin{array}{l}\text { insetos. Além disso, a respiração } \\
\text { é uma boa ferramenta para } \\
\text { monitoramento e controle de } \\
\text { processos, por bem representar o } \\
\text { estado fisiológico das células. }\end{array}$ \\
\hline 25 & $23^{a}$ & temático & $\begin{array}{l}\text { temático da FAPESP intitulado } \\
\text { Expressão de genes heterólogos } \\
\text { em células de dípteros: Biologia } \\
\text { Molecular e Engenharia de } \\
\text { Processos, }\end{array}$ \\
\hline 30 & $9^{a}$ & um dos parâmetros & uma das variáveis \\
\hline 30 & $10^{a}$ & Este parâmetro & Esta variável \\
\hline 31 & $13^{a}$ & taxa & velocidade \\
\hline 51 & $2^{a}$ & parâmetros & variáveis \\
\hline 66 & $19^{a}$ & o k $\mathrm{L}_{\mathrm{a}}$ é fixo & $\begin{array}{l}\text { como se utilizou transferência por } \\
\text { tubulação de silicone, tem-se que } \\
\text { a área de interface com o meio } \\
\text { líquido é constante e também a } \\
\text { freqüência de agitação foi } \\
\text { mantida constante tendo-se } \\
\text { assim um kLa fixo }\end{array}$ \\
\hline
\end{tabular}


Aos meus pais por toda a educação, orientação e amor durante toda a vida.

Ao Sergio por todo amor, incentivo e companheirismo.

Ao Rubens, Sueli, Rodrigo e Alexandre por toda a força, carinho e compreensão. 


\section{AGRADECIMENTOS}

Ao Prof. Dr. Aldo Tonso, meu orientador e amigo, que me recebeu tão bem e me ensinou a pensar como uma pesquisadora, transformando o trabalho em momentos de aprendizagem regados com paciência e dedicação.

Ao Dr. Carlos Augusto Pereira, pela contribuição de infra-estrutura e também pelos momentos de reflexão.

A Profa. Dra. Soraia Attie Calil Jorge por tantos ensinamentos em biologia, passados com muito carinho e amizade.

A Profa. Dra. Maria Cândida R. Facciotti por todos os ensinamentos e atenção a qualquer hora.

A Profa. Dra. Elizabeth Augusto pelos momentos de discussão e troca de idéias que tanto me ensinaram.

Ao Dr. Ronaldo Zucatelli Mendonça pelo apoio e amizade em todos os momentos.

Aos maravilhosos amigos: Isabel, Marcos, Alexandra e Mariza por todos os ensinamentos, apoio e amizade que tornaram o dia-a-dia mais prazeroso.

Aos queridos amigos do LIV: Elaine, Álvaro, Kátia, Rogério, Gregório, Coutinho, Lúcia, Mateus, Adriana Galesi, Fabiana, Adriana Yurie e Renato por todas as discussões, apoio, incentivo e carinho recebido em todos os momentos.

Ao Dr. Celso Ricardo D. Pamboukian, meu cunhado, por todo apoio e orientação no difícil recomeço desta estrada.

Ao grande amigo José Paulo Castillo Lopes da Costa por todo incentivo, apoio, amizade e carinho desde o primeiro dia.

Ao amigo Fabiano Henrique Marques por tudo o que me ensinou e por seu apoio e amizade.

Aos amigos do Bloco 20: Mariana, lara, Roberta, Saul, Marcos e aos professores: Dr. Pedro de Alcântara e Dra. Beatriz Kilikian por todos os bons momentos de convivência. 
Ao Dr. Jorge Mário C. Ferreira Junior por sua prontidão e colaboração nas análises feitas em citometria de fluxo.

Aos funcionários: Maria Abel, Dulcinéia e Francisca (LIV/Butantan); Valter, Orlinda e Andréia (Bloco 20/USP) e Elisete, Alexandre e Graça (Bloco 19/USP) que sempre estiveram prontos a colaborar no que fosse necessário.

Aos colegas do Projeto Temático, por todas as discussões e momentos de lazer e alegria.

A minha amiga Mônica, que mesmo a distância, sempre está presente em minha vida.

Aos meus pais que me educaram com amor para sempre respeitar a vida e ao próximo.

Ao meu irmão Rubens, pelo amor incondicional e por me ensinar a ser profissional, minha cunhada Sueli e meus sobrinhos Rodrigo e Alexandre que sempre estão presentes em minha vida tornando-a repleta de amor, amizade e felicidade.

Ao meu marido Sergio que é tudo o que alguém pode sonhar.

A minha tia Maria por todo amor e carinho que sempre nos deu.

Aos meus sogros, Vicente e Íris, que são parte de minha vida, cobrindo-a com muito amor e companheirismo.

Gostaria, também, de agradecer o privilégio e a honra de ter trabalhado com um grupo tão seleto e interdisciplinar quanto deste temático. $\mathrm{E}$ ainda, de ter tido a oportunidade de trabalhar com uma gama tão variada de linhagens celulares.

A toda a minha família por todo amor, incentivo e carinho, sem a qual eu nada seria.

A todos que direta ou indiretamente colaboraram com a realização deste trabalho. Ao CNPq e Fapesp pelo suporte financeiro. 
A procura da verdade é difícil e é fácil, já que ninguém poderá desvendá-la por completo ou ignorá-la inteiramente. Contudo, cada um de nós poderá acrescentar um pouco do nosso conhecimento sobre a natureza e, disto, uma certa grandeza emergirá.

(Aristóteles, 350 a.C.) 


\section{RESUMO}

A velocidade específica de respiração $\left(Q_{\mathrm{O}_{2}}\right)$ é um parâmetro fundamental para entender-se o metabolismo e o estado fisiológico celular, fornecendo informações úteis para o processo e controle em biorreatores. Neste trabalho, cultivou-se diferentes células de insetos em ambiente controlado medindo-se $\circ \mathrm{Q}_{\mathrm{O} 2} \mathrm{e}$ concentração crítica de oxigênio $\left(\mathrm{C}_{\text {crit }}\right)$. Foram utilizadas nos ensaios células de insetos Spodoptera frugiperda (Sf9) não infectadas e células de Drosophila melanogaster (S2) selvagem e recombinantes, utilizadas na expressão de diferentes proteínas. Todas as experiências foram realizadas em biorreator Inceltech com volume de trabalho de $1 \mathrm{~L}$, mantido a temperatura de $28^{\circ} \mathrm{C}$, agitação de $100 \mathrm{rpm}$ e oxigênio dissolvido (OD) a $40 \%$ da saturação de ar, com difusão por membrana de silicone com mistura gasosa $\left(\mathrm{O}_{2}\right.$ e $\left.\mathrm{N}_{2}\right)$ e vazão gasosa constante. Foi utilizado meio de cultura Sf900Il sem soro fetal bovino. $O Q_{02}$ foi medido pelo método dinâmico e pelo balanço de oxigênio na fase líquida. Neste trabalho foi implementado um novo processo durante o método dinâmico para interromper completamente a transferência gasosa durante a execução deste método. Implementou-se também uma metodologia para medição de $\mathrm{C}_{\text {crit. }}$ Chegou-se a concentrações máximas celulares $\left(X_{m}\right)$, velocidades máximas específicas de respiração $\left(Q_{02}\right)$ na fase exponencial e $C_{\text {crit }}$, conforme segue: 1) Sf9 (ATCC 1711): $X_{m}-10,7.10^{6} \mathrm{cel} / \mathrm{mL} ; Q_{02}$ - 74,7.10-18 $\mathrm{molO}_{2} /\left(\right.$ cel.s); 2) S2 (Invitrogen): $X_{m}-51,2.10^{6} \mathrm{cel} / \mathrm{mL} ; Q_{02}-3,4.10^{-18}$ $\mathrm{molO}_{2} /\left(\right.$ cel.s); $\mathrm{C}_{\text {crit }}-10 \%$; 3) S2AcGPV2 (transfectadas para expressão de GPV): $\mathrm{X}_{\mathrm{m}}$ - 26,6.10 $\mathrm{cel} / \mathrm{mL} ; Q_{02}-16,0.10^{-18} \mathrm{molO}_{2} /(\mathrm{cel} . \mathrm{s}) ; C_{\text {crit }}$ - 10\%; 4) S2MtEGFP (transfectadas para expressão de EGFP): $X_{m}-17,8.10^{6} \mathrm{cel} / \mathrm{mL}$; Q $Q_{2}-25,8.10^{-18}$ $\mathrm{molO}_{2} /\left(\right.$ cel.s); $\mathrm{C}_{\text {crit }}-5 \%$; 5) S2AcHBsAgHy (transfectadas para expressão de HBsAg): $X_{m}-16,6.10^{6} \mathrm{cel} / \mathrm{mL}$; $Q_{02}-33,6.10^{-18} \mathrm{molO}_{2} /\left(\right.$ cel.s); $C_{\text {crit }}-12 \%$. Conclui-se que as linhagens selvagens e transfectadas de $\mathrm{S} 2$ possuem entre si uma atividade respiratória diferente e também que as novas metodologias implantadas verificaram-se satisfatoriamente.

Palavras-chave: respiração celular, biorreatores, células de insetos, Drosophila melanogaster, Spodoptera frugiperda. 


\begin{abstract}
Specific respiration rate $\left(\mathrm{Q}_{\mathrm{O} 2}\right)$ is a key parameter to understand cell metabolism and physiological state, providing useful information for process supervision and control. In this work, we cultivated different insect cells in a very controlled environment, being able to measure $\mathrm{Q}_{\mathrm{O} 2}$ and critical oxygen concentration $\left(\mathrm{C}_{\text {crit }}\right)$. Wild Spodoptera frugiperda (Sf9) and wild and transfected Drosophila melanogaster S2 cells (able to produce different proteins) were used. All experiments were performed in 1-liter working volume Inceltech bioreactor, maintaining temperature controlled at $28^{\circ} \mathrm{C}$, agitation rate at $100 \mathrm{rpm}$, and dissolved oxygen (DO) at $40 \%$ of air saturation, through membrane diffusion of mixed gases $\left(\mathrm{O}_{2}\right.$ and $\left.\mathrm{N}_{2}\right)$ at constant total flow rate. SF900II serum free medium was used. Q02 was measured through dynamic method and oxygen mass balance in the liquid phase. In this work a new process was implemented during the dynamic method to interrupt completely the oxygen transfer during the execution of this method. It was also implemented a methodology for measurement of $\mathrm{C}_{\text {crit }}$ (determined when DO reduces its decay rate, without oxygen transfer). Maximum cell concentration $\left(\mathrm{X}_{\mathrm{m}}\right)$, maximum specific respiration rate $\left(\mathrm{Q}_{\mathrm{O} 2}\right)$ in the exponential phase and $C_{\text {crit }}$ were reached, as follows: 1) Sf9 (ATCC 1711): $X_{m}-10,7.10^{6} \mathrm{cel} / \mathrm{mL} ; Q_{O 2}-74,7.10^{-18} \mathrm{molO}_{2} /\left(\right.$ cel.s); 2) S2 (Invitrogen): $X_{m}-51,2.10^{6}$ $\mathrm{cel} / \mathrm{mL} ; \mathrm{Q}_{\mathrm{O} 2}-3,4.10^{-18} \mathrm{molO}_{2} /\left(\right.$ cel.s); $\mathrm{C}_{\text {crit }}-10 \%$; 3) S2AcGPV2 (transfected for GPV expression): $X_{m}-26,6.10^{6} \mathrm{cel} / \mathrm{mL} ; Q_{02}-16,0.10^{-18} \mathrm{molO}_{2} /($ cel.s $\left.) ; C_{c r i t}-10 \% ; 4\right)$ S2MtEGFP (transfected for EGFP expression): $X_{m}-17,8.10^{6} \mathrm{cel} / \mathrm{mL} ; Q_{02}$ $25,8.10^{-18} \mathrm{molO}_{2} /\left(\right.$ cel.s); $\mathrm{C}_{\text {crit }}-5 \%$; 5) S2AcHBsAgHy (transfected for HBsAg expression): $X_{m}-16,6.10^{6} \mathrm{cel} / \mathrm{mL} ; Q_{02}-33,6.10^{-18} \mathrm{molO}_{2} /\left(\right.$ cel.s); $C_{\text {crit }}-12 \%$. From these results, it can be concluded that the studied cell lines have different respiration activity and the new developed methodologies behave satisfactorily.
\end{abstract}

Key-word: cell respiration, bioreactors, insect cells, Drosophila melanogaster, Spodoptera frugiperda. 


\section{LISTA DE ILUSTRAÇÕES}

Figura 1 - Esquema das principais vias metabólicas para a Sf9 31

Figura 2 - Lagarta Spodoptera frugiperda 32

Figura 3 - Drosophila melanogaster 34

Figura 4 - Esquema do vírus da raiva. 36

Figura 5 - Esquema do vírus da Hepatite B......

Figura 6 - Resistência associadas ao transporte de oxigênio 45

Figura 7 - Representação esquemática da variação de $Q_{02}$ com C

Figura 8 - Perfil de oxigênio dissolvido durante o método dinâmico. 49

Figura 9 - Exemplo de impelidores: pás planas e hélice marinha. 52

Figura 10 - Exemplo de biorreator de tanque agitado com os impelidores. 52

Figura 11 - Exemplo de biorreatores: coluna de bolhas e airlift. 53

Figura 12 - Exemplo de biorreator de ondas 53

Figura 13 - Mapa do vetor pAcGPV. 55

Figura 14 - Mapa do vetor pMtEGFP. 55

Figura 15 - Mapa do vetor pAcHBsAgHy. 56

Figura 16 - Foto do biorreator e seus equipamentos 57

Figura 17 - Esquema da configuração do sistema de transferência de oxigênio .....59

Figura 18 - Foto da membrana de silicone no reator 59

Figura 19 - Esquema de uma câmara de Neubauer com os campos para contagem da concentração celular . 63

Figura 20 - Esquema de funcionamento de um citômetro de fluxo. 65

Figura 21 - Cálculo do $\mathrm{k}_{\mathrm{L}}$ a em meio aquoso. 67

Figura 22 - Esquema da configuração do sistema para medida da OUR no novo Método Dinâmico proposto 
Figura 23 - Representação esquemática do efeito da diminuição de oxigênio dissolvido na velocidade de respiração 71

Figura 24 - Análise em citômetro de fluxo em seu ponto máximo 109

Figura 25 - Mosaico Fluído sugerido por Singer e Nicholson 124 


\section{LISTA DE GRÁFICOS}

Gráfico 1 - Temperatura, OD, ação do controlador de OD e concentração de células viáveis do Ensaio 1 (Sf9) em função do tempo

Gráfico 2 - Medidas de OUR e QO2 por Método Dinâmico Tradicional e Balanço da Fase Líquida do Ensaio 1 (Sf9) em função do tempo. .74

Gráfico 3 - Viabilidade celular e velocidade específica de crescimento celular do Ensaio 1 (Sf9) em função do tempo .....

Gráfico 4 - Velocidade específica de crescimento celular do Ensaio 1 (Sf9) em função do tempo 75

Gráfico 5 - pH e concentração de glicose, glutamina e lactato do Ensaio 1 (Sf9) em função do tempo 76

Gráfico 6 - Velocidades específicas de consumo de glicose e glutamina e de produção de lactato do Ensaio 1 (Sf9) em função do tempo.

Gráfico 7 - Temperatura, OD, ação do controlador de OD e concentração de células viáveis do Ensaio 2 (S2a) em função do tempo

Gráfico 8 - Medidas de OUR e Q Q2 por Método Dinâmico Tradicional e Balanço da Fase Líquida do Ensaio 2 (S2a) em função do tempo.

Gráfico 9 - Viabilidade celular e velocidade específica de crescimento celular do

Ensaio 2 (S2a) em função do tempo

Gráfico 10 - Velocidade específica de crescimento celular do Ensaio 2 (S2a) em função do tempo

Gráfico 11 - pH e concentração de glicose, glutamina e lactato do Ensaio 2 (S2a) em função do tempo

Gráfico 12 - Velocidades específicas de consumo de glicose e glutamina e de produção de lactato do Ensaio 2 (S2a) em função do tempo

Gráfico 13 - Temperatura, OD, ação do controlador de OD e concentração de células viáveis do Ensaio 3 (S2b) em função do tempo 
Gráfico 14 - Medidas de OUR e QO2 por Método Dinâmico Tradicional e Balanço da Fase Líquida do Ensaio 3 (S2b) em função do tempo.

Gráfico 15 - Viabilidade celular e velocidade específica de crescimento celular do Ensaio 3 (S2b) em função do tempo

Gráfico 16 - Velocidade específica de crescimento celular do Ensaio 3 (S2b) em função do tempo

Gráfico 17 - Concentração de glicose, glutamina e lactato do Ensaio 3 (S2b) em função do tempo 88

Gráfico 18 - Velocidades específicas de consumo de glicose e glutamina e de produção de lactato do Ensaio 3 (S2b) em função do tempo 89

Gráfico 19 - Cálculo do $\mathrm{C}_{\text {crit }}$ em diferentes pontos do cultivo no Ensaio 3 (S2b) ......91

Gráfico 20 - Temperatura, OD, ação do controlador de OD e concentração de células viáveis do Ensaio 4 (GPV) em função do tempo

Gráfico 21 - Medidas de OUR por Método Dinâmico Tradicional e Balanço da Fase Líquida do Ensaio 4 (GPV) em função do tempo.

Gráfico 22 - Medidas de Q Q2 por Método Dinâmico Tradicional e Balanço da Fase Líquida do Ensaio 4 (GPV) em função do tempo. 95

Gráfico 23 - Viabilidade celular e velocidade específica de crescimento celular do Ensaio 4 (GPV) em função do tempo . 96

Gráfico 24 - Velocidade específica de crescimento celular do Ensaio 4 (GPV) em função do tempo 96

Gráfico 25 - pH e concentração de glicose, glutamina e lactato do Ensaio 4 (GPV) em função do tempo

Gráfico 26 - Velocidades específicas de consumo de glicose, glutamina e lactato do Ensaio 4 (GPV) em função do tempo. .98

Gráfico 27 - Cálculo do $\mathrm{C}_{\text {crit }}$ em diferentes pontos o cultivo do Ensaio 4 (GPV). 99

Gráfico 28 - Comparação dos $\mathrm{C}_{\text {crit }}$ encontrados através dos diferentes Métodos Dinâmicos aplicados no cultivo do Ensaio 4 (GPV) 100

Gráfico 29 - Quantidade de GPV expressa durante o Ensaio 4 (GPV) 101 
Gráfico 30 - Temperatura, OD, ação do controlador de OD e concentração de células viáveis do Ensaio 5 (EGFP) em função do tempo 102

Gráfico 31 - Medidas de OUR por Método Dinâmico Tradicional e Balanço da Fase Líquida do Ensaio 5 (EGFP) em função do tempo. 104

Gráfico 32 - Medidas de Qo2 por Método Dinâmico Tradicional e Balanço da Fase Líquida do Ensaio 5 (EGFP) em função do tempo. 104

Gráfico 33 - Viabilidade celular e velocidade específica de crescimento celular do Ensaio 5 (EGFP) em função do tempo 105

Gráfico 34 - Velocidade específica de crescimento celular do Ensaio 5 (EGFP) em função do tempo 105

Gráfico 35 - pH e concentração de glicose, glutamina e lactato do Ensaio 5 (EGFP) em função do tempo 106

Gráfico 36 - Velocidades específicas de consumo de glicose, glutamina e lactato do Ensaio 5 (EGFP) em função do tempo

Gráfico 37 - Cálculo do $\mathrm{C}_{\text {crit }}$ em diferentes pontos do Ensaio 5 (EGFP) 108

Gráfico 38 - Células Viáveis, Intensidade e Porcentagem de células florescentes ao longo do cultivo no Ensaio 5 (EGFP).

Gráfico 39 - Temperatura, OD, ação do controlador de OD e concentração de células viáveis do Ensaio 6 (HBsAg) em função do tempo.

Gráfico 40 - Medidas de OUR por Método Dinâmico Tradicional e Balanço da Fase Líquida do Ensaio 6 (HBsAg) em função do tempo.

Gráfico 41 - Medidas de Qo2 por Método Dinâmico Tradicional e Balanço da Fase Líquida do Ensaio 6 (HBsAg) em função do tempo.

Gráfico 42 - Viabilidade celular e velocidade específica de crescimento celular do Ensaio 6 (HBsAg) em função do tempo.

Gráfico 43 - Velocidade específica de crescimento celular do Ensaio 6 (HBsAg) em função do tempo

Gráfico 44 - pH e concentração de glicose, glutamina e lactato do Ensaio 6 (HBsAg) em função do tempo. 
Gráfico 45 - Velocidades específicas de consumo de glicose, glutamina e lactato do Ensaio 6 (HBsAg) em função do tempo

Gráfico 46 - Cálculo do $\mathrm{C}_{\text {crit }}$ em diferentes pontos do Ensaio 6 (HBsAg)

Gráfico 47 - Quantidade de HBsAg secretada ao longo do cultivo no Ensaio 6 (HBsAg), expressa $\left(\mathrm{ng} / 10^{7} \mathrm{cel}\right)$

Gráfico 48 - Quantidade de HBsAg secretada ao longo do cultivo no Ensaio 6 (HBsAg), expressa $(\mathrm{ng} / \mathrm{mL})$

Gráfico 49 - Comparação entre as OURs medidas pelo Método Dinâmico Proposto e BFL 121

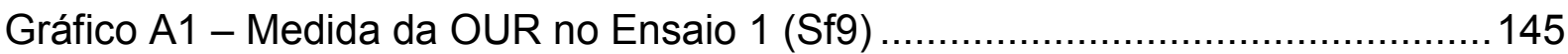

Gráfico A2 - 1ª medida da OUR no Ensaio 2 (S2a) ……................................147

Gráfico A3 - 2a medida da OUR no Ensaio 2 (S2a) ........................................148

Gráfico A4 - 3a medida da OUR no Ensaio 2 (S2a) ……................................149

Gráfico A5 - 1ª medida da OUR no Ensaio 3 (S2b) ......................................150

Gráfico A6 - 2 ${ }^{\mathrm{a}}$ medida da OUR no Ensaio 3 (S2b) ……...............................151

Gráfico A7 - 3 $3^{a}$ medida da OUR no Ensaio 3 (S2b) ........................................152

Gráfico A8 - 1ª medida da OUR no Ensaio 4 (GPV) ........................................153

Gráfico A9 - 2 ${ }^{\mathrm{a}}$ medida da OUR no Ensaio 4 (GPV) .........................................154

Gráfico A10 - 3a medida da OUR no Ensaio 4 (GPV) ......................................155

Gráfico A11 - 4ª medida da OUR no Ensaio 4 (GPV).....................................156

Gráfico A12 - 5a medida da OUR no Ensaio 4 (GPV).....................................157

Gráfico A13 - 6a medida da OUR no Ensaio 4 (GPV) ......................................158

Gráfico A14 - 7 medida da OUR no Ensaio 4 (GPV)......................................159

Gráfico A15 - 8a medida da OUR no Ensaio 4 (GPV) ........................................160

Gráfico A16 - 9a medida da OUR no Ensaio 4 (GPV)........................................161

Gráfico A17 - 10ª medida da OUR no Ensaio 4 (GPV)....................................162

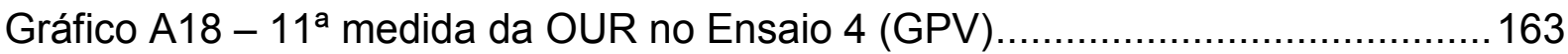


Gráfico A19 - 12 a medida da OUR no Ensaio 4 (GPV).....................................164

Gráfico A20 - 13ª medida da OUR no Ensaio 4 (GPV) .....................................165

Gráfico A21 - 14ª medida da OUR no Ensaio 4 (GPV)....................................166

Gráfico A22 - 1ª medida da OUR no Ensaio 5 (EGFP).........................................167

Gráfico A23 - 2a medida da OUR no Ensaio 5 (EGFP).....................................168

Gráfico A24 - 3a medida da OUR no Ensaio 5 (EGFP)....................................169

Gráfico A25 - 4a medida da OUR no Ensaio 5 (EGFP) ………........................170

Gráfico A26 - 5a medida da OUR no Ensaio 5 (EGFP)...................................171

Gráfico A27 - 6 medida da OUR no Ensaio 5 (EGFP) ....................................172

Gráfico A28 - 7ª medida da OUR no Ensaio 5 (EGFP)...................................173

Gráfico A29 - 8a medida da OUR no Ensaio 5 (EGFP)....................................174

Gráfico A30 - 1ª medida da OUR no Ensaio 6 (HBsAg) ……............................175

Gráfico A31 - 2a medida da OUR no Ensaio 6 (HBsAg) ...................................176

Gráfico A32 - 3a medida da OUR no Ensaio 6 (HBsAg) ….................................177

Gráfico A33 - 4ª medida da OUR no Ensaio 6 (HBsAg) ...................................178

Gráfico A34 - 5a medida da OUR no Ensaio 6 (HBsAg) …...............................179

Gráfico A35 - 6ª medida da OUR no Ensaio 6 (HBsAg) ......................................180

Gráfico A36 - 7ª medida da OUR no Ensaio 6 (HBsAg) ...................................181 


\section{LISTA DE TABELAS}

Tabela 1 - Quadro de Ensaios

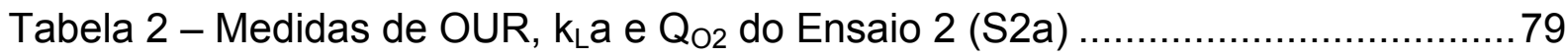

Tabela 3 - Medidas de OUR, kLa e Qo2 do Ensaio 3 (S2b) ................................... 85

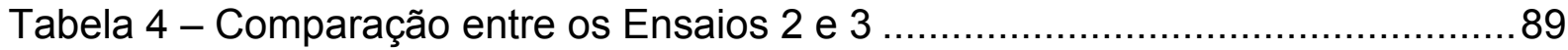

Tabela 5 - Medidas de OUR, $\mathrm{k}_{\mathrm{L}} \mathrm{a}$ e Q Q2 do Ensaio 4 (GPV) ..................................93

Tabela 6 - Medidas de OUR, kLa e Q 02 do Ensaio 5 (EGFP) …….....................103

Tabela 7 - Medidas de OUR, kடa e Qo2 do Ensaio 6 (HBsAg).............................112

Tabela 8 - Quadro comparativo entre ensaios com Sf9 ……..........................120

Tabela 9 - Quadro síntese dos resultados …………..................................129

Tabela 10 - Valores de $C_{\text {crit }}$ obtidos ...............................................................130

Tabela 11 - Coeficientes para cálculo da Constante de Henry …..........................143 


\section{LISTA DE ABREVIATURAS E SIGLAS}

$\begin{array}{ll}\text { act. } & \text { atuação } \\ \text { cel } & \text { células } \\ \mathrm{CO}_{2} & \text { gás carbônico } \\ \text { DMSO } & \text { Dimetilssulfóxido } \\ \text { DNA } & \text { ácido desoxirribonucléico } \\ \text { EGFP } & \text { Enhanced Green Fluorescent Protein } \\ \text { ELISA } & \text { Enzyme Linked Immunosorbent Assay } \\ \text { FACS } & \text { Fluorescence Activated Cell Sorter } \\ \text { GFP } & \text { Green Fluorescent Protein } \\ \text { GPV } & \text { glicoproteína do vírus da raiva } \\ \text { HBcAg } & \text { antígeno "c" do vírus da hepatite B } \\ \text { HBeAg } & \text { antígeno "e" do vírus da hepatite B } \\ \text { HBsAg } & \text { antígeno de superfície do vírus da hepatite B } \\ \text { ICB } & \text { Instituto de Ciências Biológicas } \\ \text { IPT } & \text { Instituto de Pesquisas Tecnológicas } \\ \text { mol } & \text { mol = 6,02.10 } \\ \mathrm{N}_{2} & \text { gás nitrogênio } \\ \mathrm{O}_{2} & \text { gás oxigênio } \\ \text { OD } & \text { oxigênio dissolvido } \\ \text { PDV } & \text { polyhedra-derived virus } \\ \text { S2 } & \text { células de S2 transfectadas com o vetor pMtEGFP } \\ \text { S2AcGPV2 } & \text { células de S2 transfectadas com os vetores pAcGPV e pCoHygro } \\ \text { S2AcHBaAgHy } & \text { células de S2 transfectada com o vetor pAcHBsAgHy } \\ \text { S2MtEGFP } & \end{array}$


Sf21

Sf9

Sf900 II

SFM

UFPE

UFSCar

UNICAMP

USP

UV linhagem de Spodoptera frugiperda

linhagem de Spodoptera frugiperda

meio de cultura da Gibco.

meio isento de soro fetal bovino

Universidade Federal de Pernambuco

Universidade Federal de São Carlos

Universidade Estadual de Campinas

Universidade de São Paulo

ultravioleta 


\section{LISTA DE SÍMBOLOS}

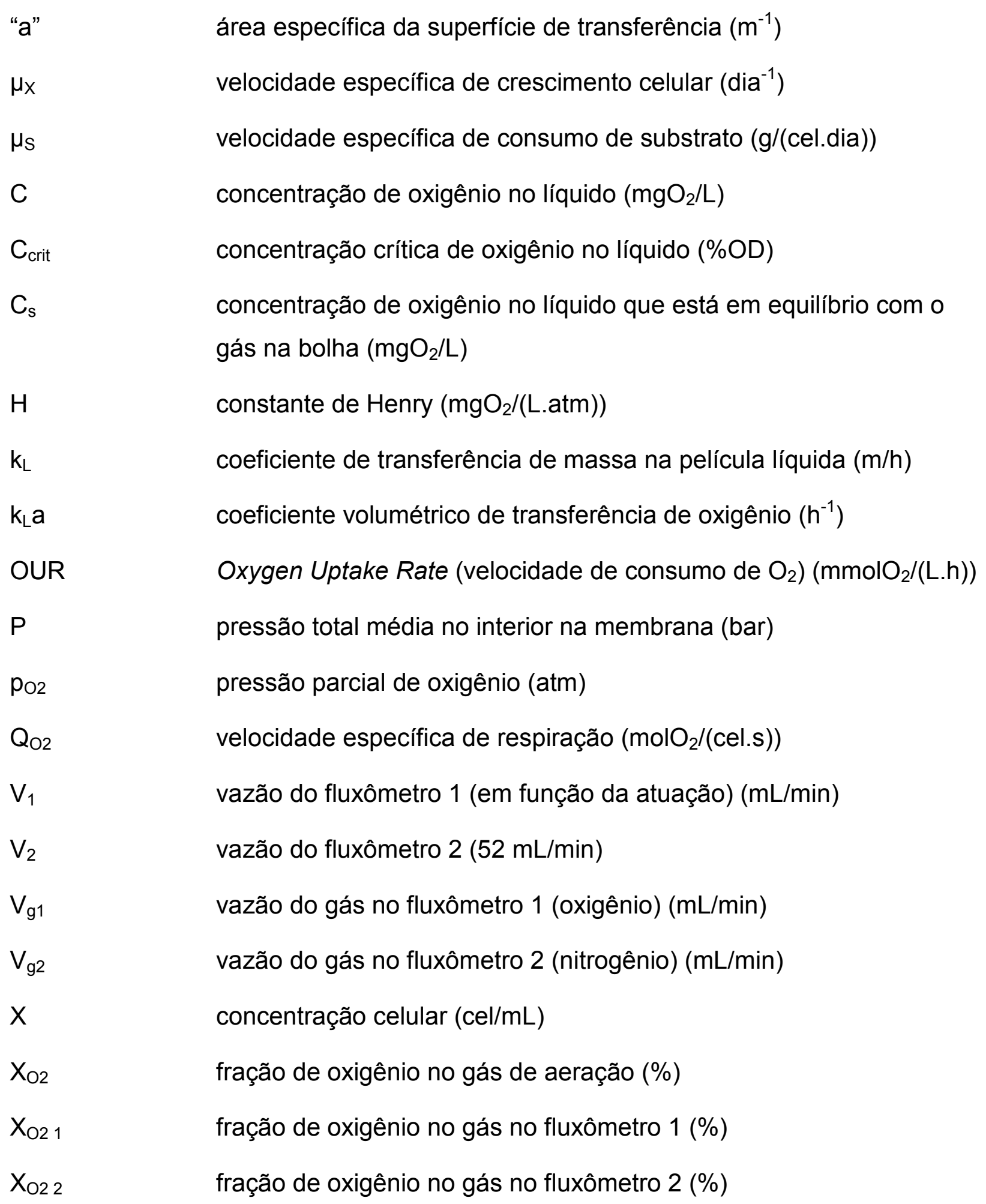

"a"

$\mu \mathrm{x}$

$\mu_{\mathrm{s}}$

C

$\mathrm{C}_{\text {crit }}$

$\mathrm{C}_{\mathrm{s}}$

$\mathrm{H}$

$\mathrm{k}_{\mathrm{L}}$

$\mathrm{k}_{\mathrm{L}} \mathrm{a}$

OUR

$\mathrm{P}$

$\mathrm{p}_{\mathrm{O} 2}$

Q 2

$\mathrm{V}_{1}$

$\mathrm{V}_{2}$

$V_{g 1}$

$\mathrm{V}_{\mathrm{g} 2}$

$\mathrm{X}$

$\mathrm{X}_{\mathrm{O} 2}$

$\mathrm{X}_{\mathrm{O} 21}$

$\mathrm{X}_{\mathrm{O} 22}$

área específica da superfície de transferência $\left(\mathrm{m}^{-1}\right)$

velocidade específica de crescimento celular $\left(\mathrm{dia}^{-1}\right)$

velocidade específica de consumo de substrato (g/(cel.dia))

concentração de oxigênio no líquido $\left(\mathrm{mgO}_{2} / \mathrm{L}\right)$

concentração crítica de oxigênio no líquido (\%OD)

concentração de oxigênio no líquido que está em equilíbrio com o gás na bolha $\left(\mathrm{mgO}_{2} / \mathrm{L}\right)$

constante de Henry $\left(\mathrm{mgO}_{2} /(\mathrm{L} . \mathrm{atm})\right)$

coeficiente de transferência de massa na película líquida $(\mathrm{m} / \mathrm{h})$

coeficiente volumétrico de transferência de oxigênio $\left(\mathrm{h}^{-1}\right)$

Oxygen Uptake Rate (velocidade de consumo de $\left.\mathrm{O}_{2}\right)\left(\mathrm{mmolO}_{2} /(\mathrm{L} . \mathrm{h})\right)$

pressão total média no interior na membrana (bar)

pressão parcial de oxigênio (atm)

velocidade específica de respiração $\left(\mathrm{molO}_{2} /(\right.$ cel.s $\left.)\right)$

vazão do fluxômetro 1 (em função da atuação) $(\mathrm{mL} / \mathrm{min})$

vazão do fluxômetro 2 ( $52 \mathrm{~mL} / \mathrm{min})$

vazão do gás no fluxômetro 1 (oxigênio) (mL/min)

vazão do gás no fluxômetro 2 (nitrogênio) (mL/min)

concentração celular (cel/mL)

fração de oxigênio no gás de aeração (\%)

fração de oxigênio no gás no fluxômetro 1 (\%)

fração de oxigênio no gás no fluxômetro 2 (\%) 


\section{SUMÁRIO}

\section{LISTA DE ILUSTRAÇÕES}

\section{LISTA DE GRÁFICOS}

\section{LISTA DE TABELAS}

\section{LISTA DE ABREVIATURAS E SIGLAS}

\section{LISTA DE SÍMBOLOS}

1 INTRODUÇÃO

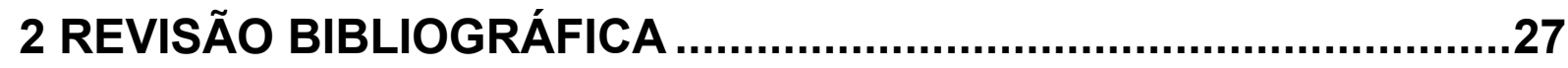

2.1 CULTURA DE CÉLULAS DE INSETOS ……………………..............27

2.2 COMPARAÇÃO ENTRE O CULTIVO DE CÉLULAS DE INSETOS E

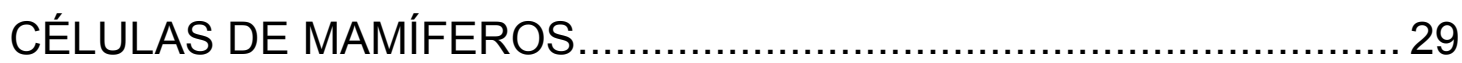

2.3 METABOLISMO DAS CÉLULAS DE INSETO...................................... 30

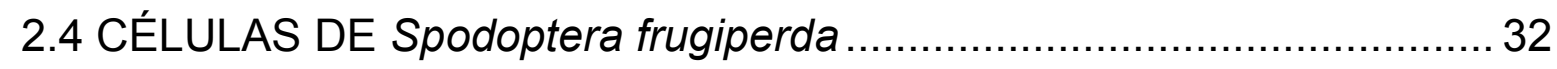

2.5 CÉLULAS DE Drosophila melanogaster............................................... 34

2.6 GLIPROTEÍNA G DO VÍRUS DA RAIVA (GPV) ................................. 35

2.7 ANTÍGENO DE SUPERFÍCIE DO VÍRUS DA HEPATITE B (HBsAg)... 36

2.8 EXPRESSÃO DE GENES HETERÓLOGOS .......................................... 38

2.9 SISTEMA DE TRANSFERÊNCIA DE OXIGÊNIO EM

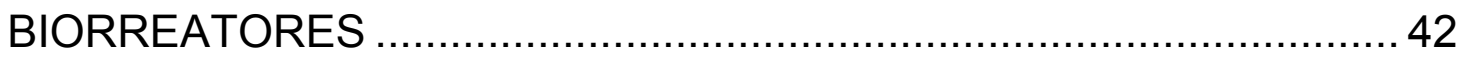

2.10 EQUACIONAMENTO DO SISTEMA DE TRANSFRÊNCIA DE

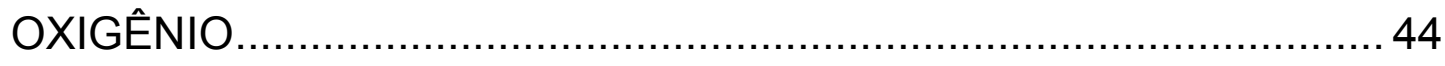

2.11 RESPIRAÇÃO CELULAR ………………………………………..... 46

2.12 MONITORAMENTO E CONTROLE DE CULTURAS EM BIORREATORES 50

2.12.1 Oxigênio dissolvido, $\mathrm{pH}$ e temperatura......................................50

2.12.2 Concentração, viabilidade celular, metabólitos ............................51 
3.1 LINHAGEM DE CÉLULAS E MEIO DE CULTURA ….......................... 54

3.2 BIORREATOR E INSTRUMENTAÇÃO ASSOCIADA .........................56

3.2.1 Sistema de transferência de oxigênio...............................................58

3.3 PROTOCOLO DE INOCULAÇÃO DO BIORREATOR .........................62

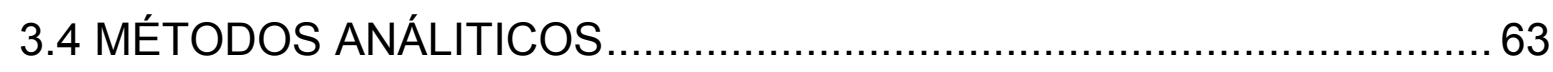

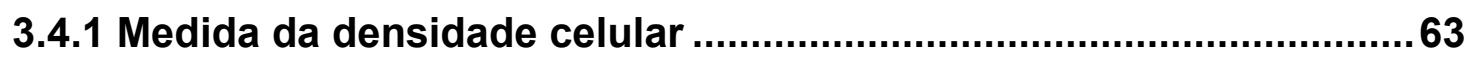

3.4.2 Medida da concentração de glicose, glutamina e lactato .................64

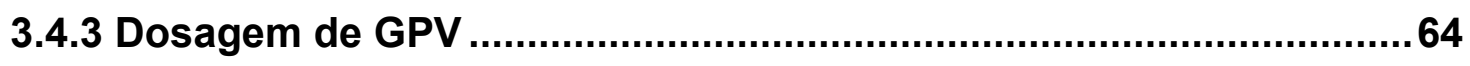

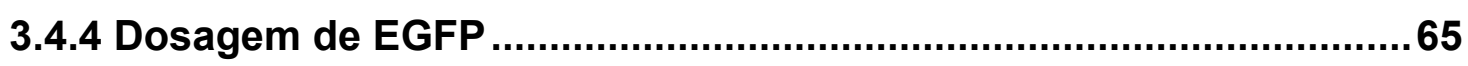

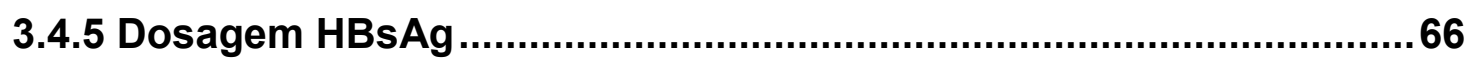

3.5 MEDIDAS DE CONSUMO E TRANSFERÊNCIA DE OXIGÊNIO .........66

3.5.1 Determinação de $k_{\llcorner} a$, OUR e $Q_{O 2}$ pelo Método Dinâmico.................66

3.5.2 Determinação contínua de OUR por Balanço na Fase

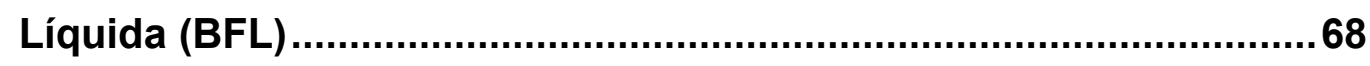

3.5.3 Cálculo da velocidade específica de crescimento............................68

3.5.4 Anulação completa da transferência de oxigênio.............................69

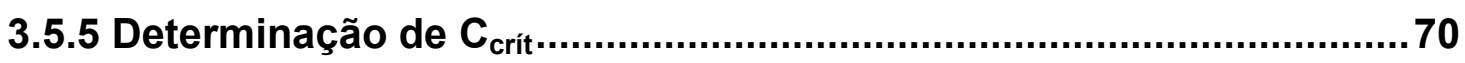

4 RESULTADOS E DISCUSSÃO .................................................72

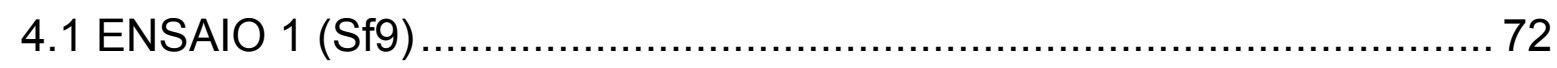

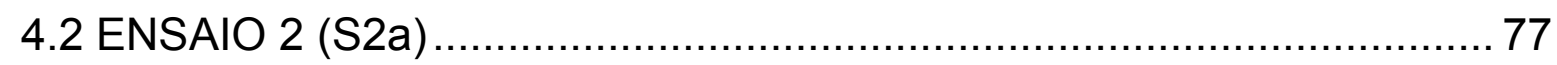

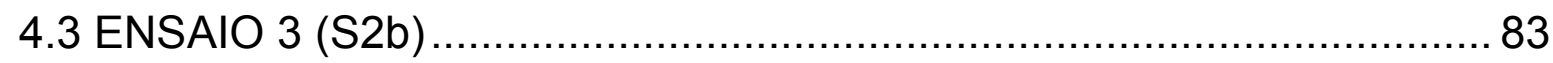

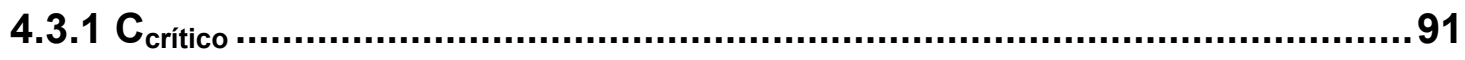

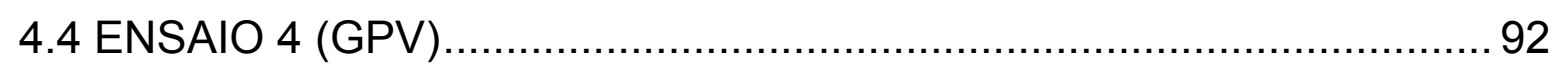

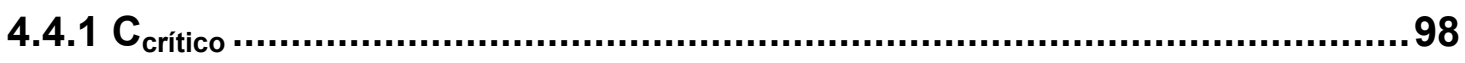

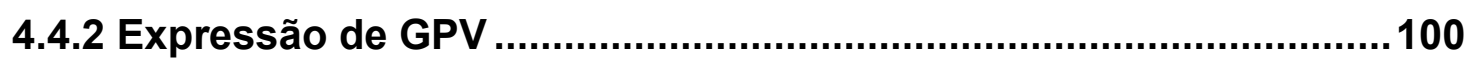

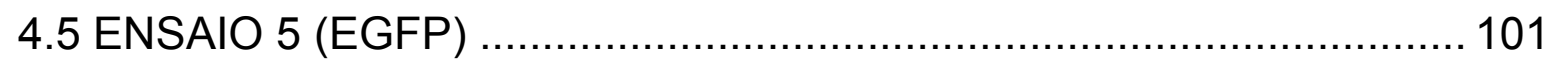

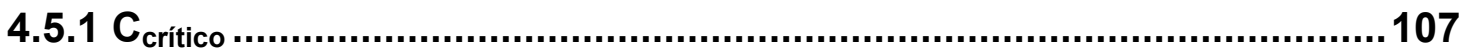




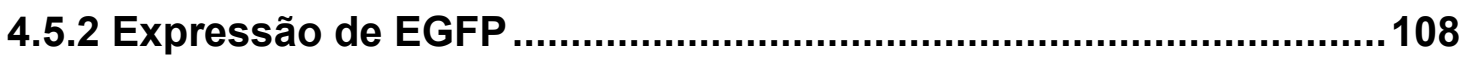

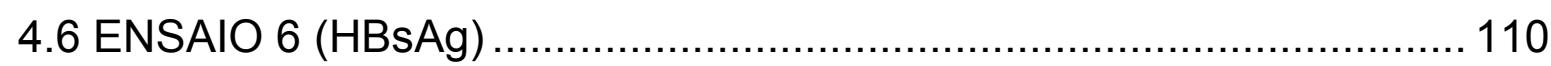

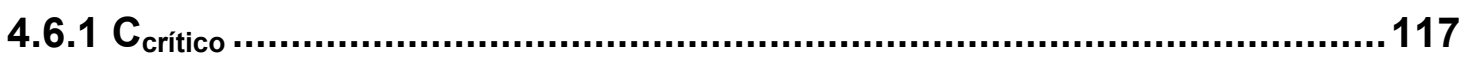

4.6.2 HBsAg secretada ...................................................................118

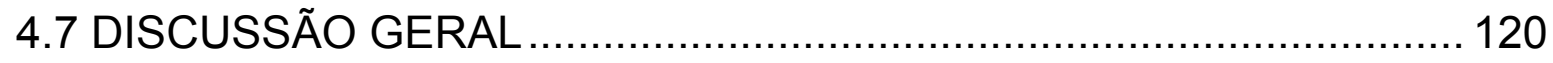

4.8 NOVA PERPECTIVA DE DISCUSSÃO ….......................................... 123

4.9 CONTINUIDADE DE TRABALHO ….............................................. 128

5 CONCLUSÃO …......................................................................129

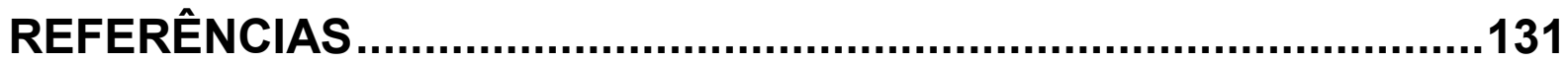

APÊNDICE A - Cálculo da pressão média no interior da membrana de silicone .....................................................................................139

APÊNDICE B - Cálculo da Constante de Henry para meio de cultura SF900 II 141

APÊNDICE C - Cálculo do oxigênio dissolvido em meio de cultura SF900 II..144 APÊNDICE D - Medida de OUR, $k_{\mathrm{L}}$ a e Qo2 do Ensaio 1 (Sf9)..........................145

APÊNDICE E - Medida de OUR, $k_{\mathrm{L}} \mathrm{a}$ e Q Q2 do Ensaio 2 (S2a) ..........................147

APÊNDICE F - Medida de OUR, $k_{L} a$ e Q Q2 do Ensaio 3 (S2b) ..........................150

APÊNDICE G - Medida de OUR, $\mathrm{k}_{\mathrm{L}} \mathrm{a}$ e Q $\mathrm{O2}$ do Ensaio 4 (S2AcGPV2) ...............153

APÊNDICE H - Medida de OUR, $k_{\mathrm{L}} \mathrm{a}$ e $Q_{02}$ do Ensaio 5 (S2MtEGFP) ................169

APÊNDICE I - Medida de OUR, $k_{\llcorner}$a e $Q_{02}$ do Ensaio 6 (S2AcHBsAgHy) ..........175 


\section{INTRODUÇÃO}

Sistemas produtivos para a indústria biotecnológica utilizando células de insetos são reconhecidamente importantes, pois sua utilização destina-se à produção de vacinas, bioinseticidas, enzimas e hormônios entre outras notáveis aplicações.

Em relação às células de mamíferos, as células de insetos possuem a vantagem de serem de fácil cultivo crescendo a temperatura ambiente sem a necessidade de estufa de $\mathrm{CO}_{2}$ e de estabelecerem rapidamente linhagens estáveis que secretam proteína recombinante com altos níveis de expressão.

Culturas de células animais em grande escala têm sido largamente utilizadas pelos laboratórios de investigação básica e indústrias para a obtenção de uma grande variedade de produtos destinados à investigação, diagnósticos, uso terapêutico e também controle biológico na agricultura. Um grande esforço vem sendo despendido para se desenvolver metodologias que possam permitir culturas celulares em alta densidade e que levem à produção de grandes quantidades de um determinado produto. Assim, tecnologias para a preparação de produtos virais, tais como antígenos e vacinas em culturas celulares, bem como proteínas com fins terapêuticos e diagnósticos vêm sendo desenvolvidas, há alguns anos, com bastante sucesso. São tecnologias que permitem uma produção em larga escala, com alto grau de controle e reprodutibilidade (IVEY-HOYLE, 1991), além de permitir a produção de proteínas, com características qualitativas aceitáveis em relação a sua capacidade imunizante e que podem ser utilizadas na preparação de vacinas (GOOSEN, 1993).

Diferentes sistemas de culturas, principalmente em suspensão, têm-se mostrado de grande eficiência para a preparação de produtos biotecnológicos. Os sistemas em suspensão caracterizam-se pelas células crescerem livremente no meio de cultura, sem a necessidade de suporte para o crescimento e mantidas por sistemas adequados de agitação e em ambiente favorável.

As células animais são estritamente aeróbicas necessitando, portanto, de suprimento de oxigênio constantemente. Porém, elas possuem uma grande sensibilidade ao estresse causado pelo sistema de transferência de $\mathrm{O}_{2}$, seja ele decorrente do sistema de agitação mecânica ou do sistema de aeração, o que se 
torna mais crítico nos sistemas com células de insetos, pois estas são ainda mais sensíveis.

Para o cultivo dessas células é fundamental que os sistemas sejam bem dimensionados no que tange a tipo de meio de cultura, temperatura de trabalho e condições de agitação e aeração, pois é necessária uma transferência de oxigênio eficiente e otimizada para que o sistema possa vir a ser utilizado em escala industrial (centenas ou milhares de litros de cultura).

A contínua transferência de oxigênio ao cultivo celular é importante, pois o oxigênio é consumido para a oxidação da glicose, porém sua solubilidade em água é baixa, tornando-se muitas vezes um fator limitante ao aumento de escala. Portanto, o estudo da intensidade de respiração (velocidade específica e consumo total de oxigênio) e da otimização das condições de cultivo em biorreator serve para nortear outros estudos relacionados à utilização de células de insetos.

O objetivo geral deste trabalho é investigar as principais variáveis na respiração e na transferência de oxigênio durante o crescimento de diferentes linhagens de células de insetos como Spodoptera frugiperda (Sf9), Drosophila melanogaster (S2) selvagem e transfectadas para a expressão de GPV, EGFP e HBsAg.

Os objetivos específicos são: a) determinar a velocidade específica de respiração das células; b) determinar a concentração crítica de oxigênio, ou seja, aquele abaixo da qual a célula respira mais lentamente e c) propor um protocolo de trabalho, tanto para o ensaio como para o tratamento de dados, para unificação do estudo dos parâmetros da respiração de uma cultura celular.

Este trabalho é parte integrante de um projeto temático que visa a expressão gênica da glicoproteína $\mathrm{G}$ do vírus da raiva (GPV) e do antígeno de superfície do vírus da hepatite B (HBsAg) em células de Drosophila melanogaster (S2) para a produção de vacinas e kits diagnósticos. Esse projeto envolve o Instituto Butantan, USP, IPT, UNICAMP e UFSCar e foi desenvolvido no Laboratório de Células Animais da Engenharia Química da Escola Politécnica da Universidade de São Paulo e no Laboratório de Imunológica Viral do Instituto Butantan. Os outros grupos estudam os diferentes aspectos do crescimento de linhagens selvagens e transfectadas de Drosophila melanogaster e da produção de proteínas heterólogas. Há estudos de 
biologia molecular, otimização de meios de cultura, otimização de biorreatores e modelagem matemática.

Com relação à atividade respiratória, este trabalho buscar continuar e complementar os trabalhos iniciados Marques (2005), que estudou a influência da concentração de oxigênio dissolvido (OD) no crescimento da linhagem de Spodoptera frugiperda (Sf9) e na produção de poliedros de baculovírus. Estes estudos foram importantes para balizar o controle de oxigênio dissolvido em biorreator e também como estudo prévio da atividade respiratória da Sf9, já que o que existe na literatura sobre a linhagem S2 é muito precário.

Portanto, como no cultivo de células animais, especialmente de inseto, a transferência de oxigênio é um fator importante para o aumento de escala e produtividade, o estudo da atividade respiratória e das diferentes formas de transferência de oxigênio servirá para complementar os resultados que serão obtidos pelos outros grupos desse projeto, assim como indicar condições otimizadas a serem utilizadas. 


\section{REVISÃO BIBLIOGRÁFICA}

\subsection{CULTURA DE CÉLULAS DE INSETOS}

As primeiras tentativas de culturas de células de inseto ocorreram por volta de 1915, sendo que até 1959 ainda não existia uma linhagem de células permanentes, apenas observava-se o crescimento e prolongamento de tecidos (GRACE, 1959). Um meio de cultura adequado à manutenção de célula in vitro era um dos principais problemas. Assim, alguns estudos buscando uma formulação de meio de cultura para células de inseto passaram a ser realizados (VAUGHN; FAN, 1997; WILKIE; STOCKDALE; PIRT, 1980). A área de interesse de estudo era a fisiologia do inseto, gametogênese, morfogênese e diferenciação, atuação de hormônios em insetos, entre outros. Após alguns anos, é que se pensou no uso dessas células como hospedeiras para o cultivo de parasitas (CESTARI; SIMÕES, 1978).

Sistemas de inclusão de um fragmento de ácido nucléico em um vetor com o objetivo de expressar proteínas surgiram na década de 70 e vêm-se desenvolvendo rapidamente. Esta metodologia vem sendo utilizada com várias aplicações, como a produção de vacinas, a produção de proteínas em larga escala, o estudo do metabolismo celular, o estudo da expressão gênica quanto aos aspectos de transcrição e tradução de proteínas, a replicação de DNA e ainda os mecanismos envolvidos na mutagênese e reparo de DNA. Diferentes sistemas de expressão de vários genes heterólogos foram obtidos em relativamente pouco tempo.

Muitos sistemas de expressão gênica podem ser utilizados para a produção de proteínas recombinantes e se baseiam em bactérias, leveduras e também em células animais e de insetos. A escolha do sistema de expressão depende de qual a aplicação terá a proteína recombinante e do grau de purificação requerido.

Bactérias podem expressar proteínas em grande quantidade, com menor tempo de produção e fácil manipulação, porém o rendimento e a qualidade podem ser comprometidos quando a proteína é expressa intracelularmente requerendo uma etapa de renaturação devido à ação de proteases empregadas na lise celular. 
Além disto, células de insetos têm sido utilizadas na produção de proteínas recombinantes de mamíferos por serem capazes de realizar modificações póstraducionais na complexidade requerida.

Leveduras podem secretar a proteína recombinante e requerem um meio simples, portanto de baixo custo, no entanto com freqüência não permitem modificações póstraducionais na proteína sintetizada, que é essencial para sua função. Em células animais, a proteína recombinante, que pode também ser expressa extracelularmente, é capaz de promover adequadamente as modificações pós-traducionais na proteína sintetizada e podem receber múltiplos plasmídeos, mas seu cultivo requer a utilização de meios de culturas ricos e de custo mais elevados.

Como alternativa a estes sistemas utiliza-se a expressão de proteínas recombinantes através da infecção de células de inseto que geram uma maior quantidade de proteína recombinante de forma mais segura. Isto ocorre, pois o baculovírus é o infectante natural destas células, apresentando transformação celular estável. Contudo, a maior dificuldade de empregar-se este sistema é a difícil manipulação do vetor de expressão (VERMA; BOLETI; GEORGE, 1998).

A expressão de genes heterólogos via vetor baculovírus é comparável à expressão de proteínas recombinantes através de transfecção de genes. Neste sentido, células de Spodoptera frugiperda (Sf9) têm sido freqüentemente utilizadas para a obtenção de proteínas codificadas por genes heterólogos carregados por baculovírus. Uma das grandes dificuldades encontradas na obtenção de proteínas recombinantes via sistema de expressão vetor baculovírus é a ocorrência de proteólise, ou seja, a liberação de proteases capazes de afetar a qualidade e a quantidade do produto de interesse produzido por este sistema. Segundo Ikonomou; Schneider e Agathos (2003), as proteases podem ser produzidas por células de inseto como resultado do estresse causado pela infecção por baculovírus, durante o ciclo de infecção, podendo ser também liberadas após a lise celular. Este problema pode ser agravado pelo emprego de meios livre de soro no cultivo destas células, já que as proteínas com função protetora, como albumina e macroglobulinas, estão ausentes.

Várias células de inseto, atualmente, têm sido comparadas a células de mamíferos, mostrando vantagens sobre estas, tais como o fácil cultivo, devido à alta tolerância para osmolalidade, à alta concentração de produtos obtidos e aos altos níveis de 
expressão quando infectadas com um baculovírus recombinante (IKONOMOU; SCHNEIDER; AGATHOS, 2003).

Uma das alternativas para expressão de proteínas recombinantes se baseia em células de inseto, que podem expressar proteínas recombinantes empregando células de dípteros transfectadas. Essas células atingem densidades celulares superiores às observadas para lepidópteros (AGATHOS, 1991), que são utilizadas para a produção de poliedros de vírus para bioinseticida e produção de proteínas heterólogas de interesse, utilizando baculovírus recombinantes desenvolvidos em células de Spodoptera frugiperda (Sf9). Estas células têm sido utilizadas devido à facilidade de seu cultivo, no entanto, esse sistema apresenta o inconveniente de se constituir num sistema de expressão gênica transiente, onde há perda da expressão por lise celular devido à infecção. Alguns sistemas de expressão permanente em células de inseto, onde a expressão de gene heterólogo permanece durante um longo período, têm sido desenvolvidos.

\subsection{COMPARAÇÃO ENTRE O CULTIVO DE CÉLULAS DE INSETOS E CÉLULAS DE MAMÍFEROS}

Células de insetos, geralmente, são cultivadas em suspensão. Em vista disto, não necessitam de suporte sólido, desenvolvendo-se livremente no meio de cultura. As células são mantidas através de repiques sucessivos, pela retirada do meio saturado por metabólitos e desprovido de nutrientes, e a subseqüente adição de meio fresco (BOVO, 2006).

Destacam-se também entre os fatores que influenciam o cultivo celular a temperatura, o pH, a pressão osmótica, a agitação, e a concentração de oxigênio dissolvido (MITSUHASHI, 1989). A combinação de fatores variados determina o sucesso do cultivo in vitro das células, tanto de mamíferos quanto de insetos. Células de mamíferos apresentam uma temperatura ótima para o desenvolvimento celular em torno de $37^{\circ} \mathrm{C}$, enquanto que células de insetos desenvolvem-se na faixa de 27 a $29^{\circ} \mathrm{C}$, dependendo da linhagem. $\mathrm{O} p \mathrm{pH}$ adequado para $\mathrm{o}$ bom desenvolvimento de células de mamíferos situa-se na faixa de 6,8 a 7,8, para tanto, utilizam-se agentes tamponantes e ar acrescido de $5 \%$ de $\mathrm{CO}_{2}$ para a manutenção 
do pH ótimo de operação. $\mathrm{O}$ pH adequado no cultivo de células de insetos situa-se, geralmente, entre 6,5 e 7, não havendo a necessidade de acréscimo de dióxido de carbono, o que reduz a complexidade e os custos do cultivo.

Células de insetos revelam-se significativamente mais robustas quanto ao cultivo, principalmente em relação à manutenção, facilidade de adaptação na mudança de sistemas aderentes para suspensos e, principalmente, por apresentarem maior resistência a estresse ambiental, como mudanças de $\mathrm{pH}$ e de osmolalidade (IKONOMOU; SCHNEIDER; AGATHOS, 2003).

A osmolalidade é um dos parâmetros físico químico que merece atenção especial no meio de cultura. Este parâmetro leva em conta o número total de partículas osmoticamente ativas em solução, sendo igual à soma das molalidades de todos os solutos presentes nesta solução. A maioria dos meios de cultivo para células é formulada para ter uma osmolalidade entre 260 e $330 \mathrm{mOs} / \mathrm{kg}$, aceitável para a maioria das células (FRESNHEY, 1994).

Assim, novas tecnologias têm sido desenvolvidas para a obtenção de bioprodutos a partir de células de insetos.

\subsection{METABOLISMO DAS CÉLULAS DE INSETO}

A maioria dos estudos existentes de células de inseto refere-se a linhagens de lepidópteros, como a Sf9 de Spodoptera frugiperda.

Os compostos de relevância para o cultivo de células de inseto são as fontes de carbono e nitrogênio, glicose e glutamina e os produtos metabólicos lactato e amônio. Na Figura 1, tem-se as rotas metabólicas de consumo de glicose e glutamina e formação de lactato e amônio para o cultivo de células Sf9. 


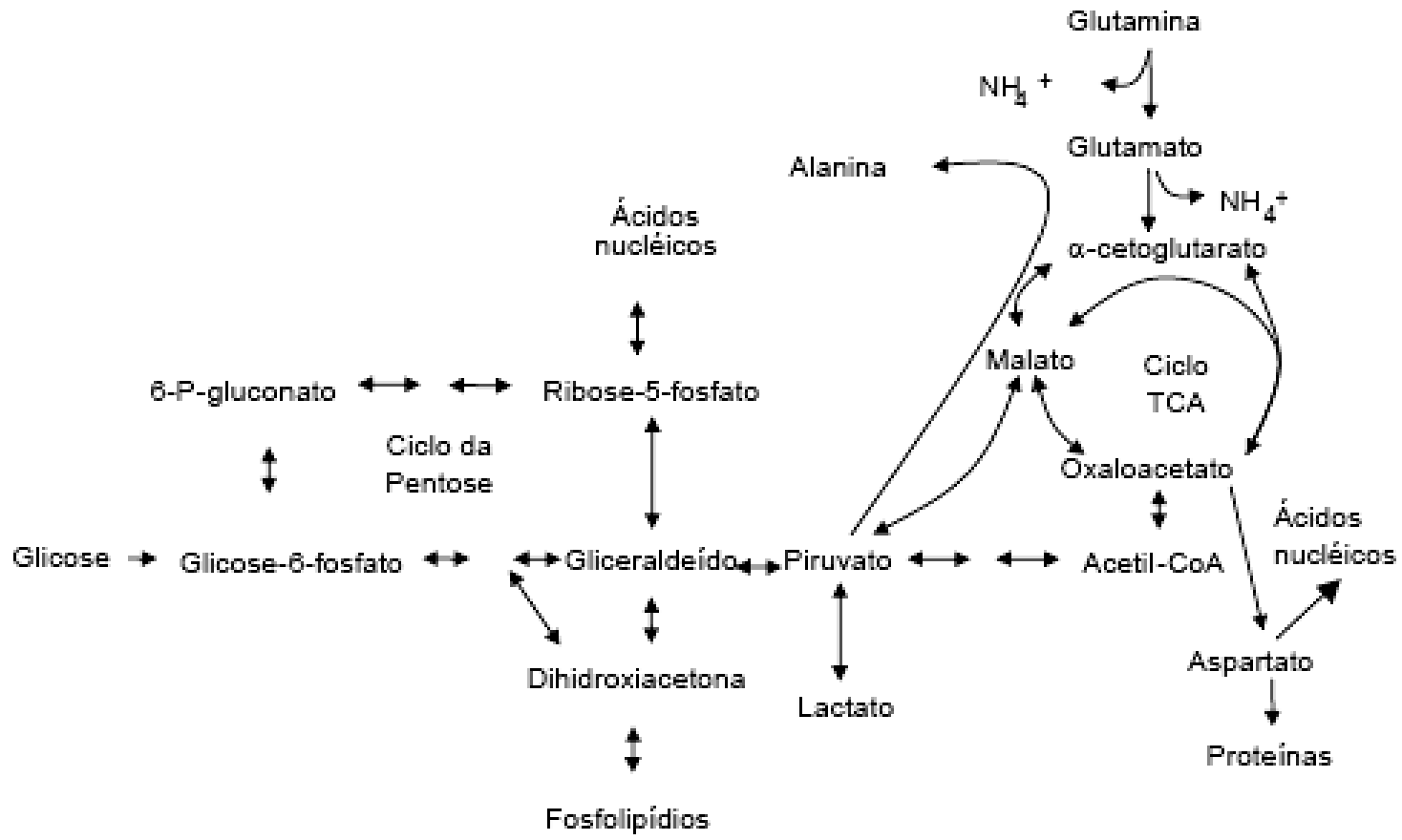

Figura 1 - Esquema das principais vias metabólicas para a Sf9 (Adaptado de ÖHMAN; LJUNGGREN; HAGGSTROM, 1995)

O carboidrato mais usualmente consumido é a glicose, que é considerada a mais importante para o crescimento celular (BÉRDAD; TOM; KAMEN, 1993; BHATIA et al., 1997; MENDONÇA; PALOMARES; RAMÍREZ, 1999) e que produz lactato como principal metabólito (DREWS; PAALME; VILU, 1995). A glutamina consumida pode ser convertida em glutamato e amônio, mas em alguns casos a glutamina pode ser sintetizada pelas próprias células em quantidades capazes de suprir o crescimento celular (ÖHMAN et al., 1996). O lactato é acumulado pelas células de inseto em baixos níveis e pode ser produzido sob condições de estresse provocado pela limitação de oxigênio (IKONOMOU; SCHNEIDER; AGATHOS, 2003) ou ainda consumido para o suprimento de carbono ou energia ao metabolismo celular.

Vários trabalhos indicam que em limitação de glicose as células de insetos podem passar a consumir sacarose (GRACE, 1966; WANG; KWONG; BENTLEY, 1993) reduzindo a taxa de crescimento. Assim, os elevados valores de consumo de glicose, ou outros intermediários da via glicolítica, sugerem a presença de uma via glicolítica e de um ciclo de Krebs bastante ativos (BHATIA et al. 1997).

Nas células Sf9 o excesso de amônia é excretado na forma de alanina, um subproduto não tóxico para as células (ÖHMAN et al., 1996). 
O metabolismo de carboidratos em células S2 é ainda desconhecido, porém estudos sugerem que a glicose seja a principal fonte de carbono e, provavelmente, a trealose seja um nutriente essencial para o crescimento desta linhagem celular (Guy, 1997).

\subsection{CÉLULAS DE Spodoptera frugiperda}

Na produção de proteínas, utilizam-se as células de insetos por serem eucariontes superiores, pois são capazes de modificar os produtos após a tradução, gerando proteínas estruturalmente idênticas ou muito semelhantes às encontradas in vivo.

Uma das células de insetos mais comumente utilizada são as células epiteliais do ovário da lagarta Spodoptera frugiperda (Figura 2), que é um lepidóptero (animais artrópodes da classe Lepidóptera, como borboletas e mariposas) gerando as linhagens conhecidas como Sf9 e Sf21. Estas células são utilizadas para a produção de bioinseticidas e proteínas recombinantes.

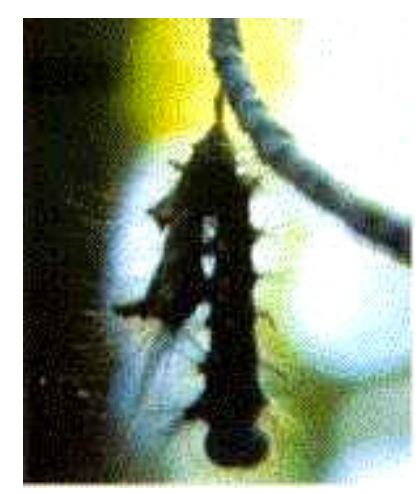

Figura 2 - Lagarta Spodoptera frugiperda

Para a produção de proteínas recombinantes as células de inseto são transfectadas com o genoma viral recombinante de um baculovírus que é um tipo de vírus que infecta apenas células de insetos. Esta transfecção gera partículas virais recombinantes que são exportadas para o exterior das células, transformando o meio de cultura em um inóculo contendo o baculovírus recombinante, que é usado para infectar novas células e produzir a proteína de interesse. As vantagens deste sistema são: 
- As células de insetos processam proteínas complexas, produzindo-as do mesmo modo que são produzidas in vivo ou de modo bastante semelhante;

- Se a proteína tiver um peptídeo como sinal de secreção, que seja reconhecido pelas células de inseto, esta é exportada para o sobrenadante da cultura. Como já existem células de inseto adaptadas ao cultivo em meio sem soro fetal bovino, a proteína secretada pode ser purificada a partir do meio de cultura com facilidade;

- Pelo fato do baculovírus ser específico para insetos, não há risco de contaminação dos seres humanos envolvidos;

- O nível de produção é elevado, se comparado com os níveis obtidos quando se utiliza outros sistemas de expressão.

Os baculovírus apresentam uma forma viral que é a membrana sintetizada no núcleo da célula infectada e são oclusos em cristais protéicos denominados corpos de oclusão (polyhedra-derived virus - PDV), e tem sido utilizado como um inseticida microbiano (MOSCARDI; SOUZA, 2002) onde o vírus é aplicado quantas vezes e o quanto for necessário, de modo semelhante à aplicação de um inseticida químico. Porém o inseticida baculovírus difere do inseticida químico, pois necessita de um tempo maior para matar o inseto, mas em contrapartida ele é multiplicado e disseminado pelo hospedeiro, podendo controlar o inseto alvo com menor número de aplicações. No Brasil são utilizados diversos baculovírus para o controle de pragas (CASTRO; SOUZA; BILIMORIA, 1999).

A produção do bioinseticida baculovírus pode ser realizada em dois sistemas distintos: in vivo onde os PDVs são produzidos em uma lagarta viva, seguindo exatamente o ciclo natural do vírus, ou in vitro onde o vírus é replicado em uma cultura de células de inseto, diferindo do ciclo natural do vírus. Todos os inseticidas derivados de baculovírus comercialmente disponíveis são produzidos in vivo. Porém estudos tem sido realizados para a otimização da produção in vitro. 


\subsection{CÉLULAS DE Drosophila melanogaster}

A Drosophila melanogaster é um inseto díptero (dois pares de asas) pertencente ao gênero das moscas da fruta como mostra Figura 3. Esta espécie é um dos animais mais utilizados em experiências genéticas, sendo um dos mais importantes organismos modelo da Biologia.

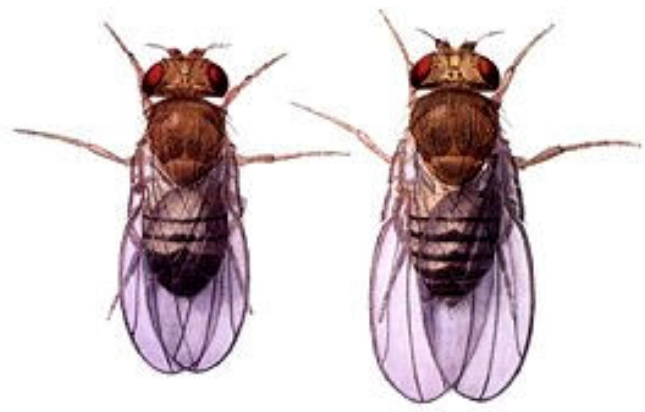

Figura 3 - Drosophila melanogaster, macho (esquerda) e fêmea (direita).

As células de Drosophila melanogaster começaram a ser estudadas em 1909 pelo americano Thomas Hunt Morgan e nesse estudo ele conseguiu demonstrar as teorias de Mendel. Essas células são ainda hoje estudadas e representam grande importância para a genética e para a bioquímica. Dos quase 300 genes identificados no genoma humano e responsáveis por doenças hereditárias, mais da metade têm genes análogos no genoma da Drosophila (COELHO, 2002).

Cerca de 94 linhagens de células de drosófila são independentemente cultivadas, das quais 12 têm sido mais facilmente manipuladas. Para a expressão de genes heterólogos duas linhagens de células Schneider têm sido bastante utilizadas, as linhagens S2 e S3 (CHERBAS; MOSS; CHERBAS, 1994). Essas células se caracterizam pela semi-aderência e são células derivadas de cultura primária de embriões em estágios tardios de desenvolvimento (SCHNEIDER, 1972).

Várias proteínas já foram expressas em células de Drosophila melanogaster (S2), como por exemplo, a dopamina $\beta$ hidroxilase humana (LI et al., 1996) e o antígeno de superfície do vírus da hepatite B (HBsAg) (DELM; WOLF; WAGNER, 1999). Assim as células de drosófila têm a capacidade de expressar genes sem alterar 
funções e propriedade da proteína, enquanto sistemas com infecção viral podem comprometer vias secretoras da célula.

\subsection{GLICOPROTEÍNA G DO VÍRUS DA RAIVA (GPV)}

A vacina da raiva protege as pessoas que foram lambidas, mordidas ou arranhadas por um animal que tenha a raiva. A raiva é uma grave doença, pois pode matar as pessoas que não forem tratadas e ataca o sistema nervoso central. A doença causa confusão, problemas de respiração e ataques. Estes sinais podem demorar a se manifestar até oito semanas após o contágio. Nesse ponto, já não há mais a possibilidade de cura. A vacina deve ser administrada o mais rápido possível em todas as pessoas que tiveram contato com o animal doente.

Hoje se tem 2,5 bilhões de pessoas expostas ao risco de contágio em cerca de 100 países. Nos países da Europa e América do Norte, a raiva silvestre representa a principal preocupação, estando a urbana controlada e até mesmo erradicada (GERMANO, 1994). Nos países da América Latina, Ásia e África, a raiva urbana é responsável, anualmente, por 50 a 60 mil mortes humanas, a maioria de crianças. $\mathrm{Na}$ Índia, por exemplo, já se atingiram 20 mil casos de raiva por ano e, na China, 5 mil. Na América Latina esses números não assumem proporções tão graves. No Brasil, têm-se em média 60 óbitos humanos por ano, destes $76 \%$ só na região nordeste. Morcegos, cães e gatos são os animais que apresentam maior risco de contrair raiva. Bovinos, suínos, caprinos e eqüinos apresentam risco médio (CCAUFES, 2006).

A replicação do vírus da raiva inicia-se através da adesão da espícula trimérica viral glicoproteína G, portanto a imunização se dará através de anticorpos protetores para a glicoproteína G. Na Figura 4 pode-se ver o esquema do vírus da raiva e a glicoproteína G. 


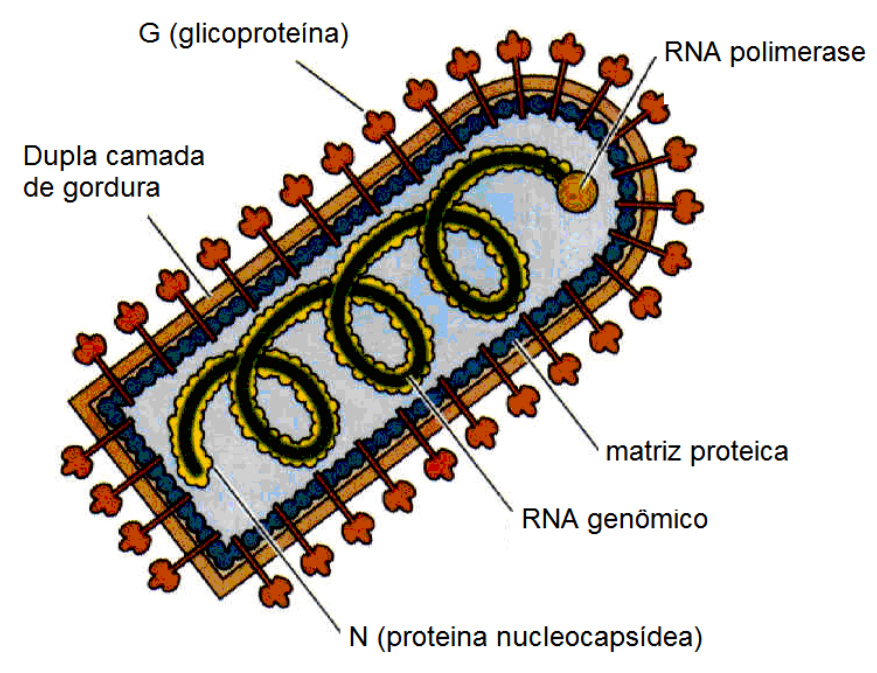

Figura 4 - Esquema do vírus da raiva (CCAUFES, 2006).

Na vacina de primeira geração é utilizado substrato animal para obtenção de massa viral, como tecido nervoso animal adulto (carneiros, cabras e coelhos), ovos embrionados e cérebro de animal lactente (camundongos - Fuenzalida, coelhos e ratos) e podem ser do tipo inativadas ou atenuadas (PÉREZ; PAOLAZZI, 1997). A segunda geração é produzida em culturas celulares, como culturas de células primárias de mamíferos, células diplóides e heteroplóides e também podem apresentar-se na forma inativada ou atenuada. O soro anti-rábico também é importante, pois o tratamento pós-exposição mostra-se bastante efetivo na indução da proteção. Atualmente, produz-se no Brasil, a vacina anti-rábica em células Vero, livre de soro fetal bovino, o que reduz o risco de transmissão de zoonoses e prions.

Todas as vacinas contra a raiva hoje existentes no mundo, de uso humano, são inativadas, ou seja, não apresentam vírus vivos. Porém as vacinas de cultivo celular são as que apresentam menos riscos de efeitos colaterais.

\subsection{ANTÍGENO DE SUPERFÍCIE DO VÍRUS DA HEPATITE B (HBsAg)}

Mais de $50 \%$ da população mundial já foi contaminada pelo vírus da hepatite $\mathrm{B}$. Estima-se algo em torno de 2 bilhões de pessoas que já entraram em contato com o vírus, 350 milhões de portadores crônicos, 50 milhões de novos casos a cada ano e 
quase 1 milhão de pessoas mortas por ano. Em áreas com maior incidência, 8 a $25 \%$ das pessoas carregam o vírus e de 60 a $85 \%$ já foram expostas. No Brasil, $15 \%$ da população já foi contaminada e 1\% é portadora crônica (HEPCENTRO, 2007).

Os portadores crônicos de hepatite B apresentam maior risco de morte por complicações relacionadas a hepatite crônica, como cirrose e carcinoma hepatocelular.

O vírus que causa a hepatite B é um vírus DNA, transmitido por sangue (transfusões, agulhas contaminadas, relação sexual, após o parto, etc.). Não se adquire hepatite B através de talheres, pratos, abraço ou qualquer outro tipo de atividade social aonde não ocorra contato com sangue. Após a infecção, o vírus concentra-se quase que totalmente nas células do fígado, aonde seu DNA fará o hepatócito construir novos vírus.

O vírus da hepatite B (Figura 5) é resistente, chegando a sobreviver sete dias no ambiente externo em condições normais e com risco de, se entrar em contato com sangue através de picada de agulha, corte ou machucados (incluindo procedimentos de manicure com instrumentos contaminados), levar a infecção em 5 a $40 \%$ das pessoas não vacinadas (o risco é maior do que o observado para o vírus da hepatite C - 3 a $10 \%$ ou o da AIDS - 0,2-0,5\%).

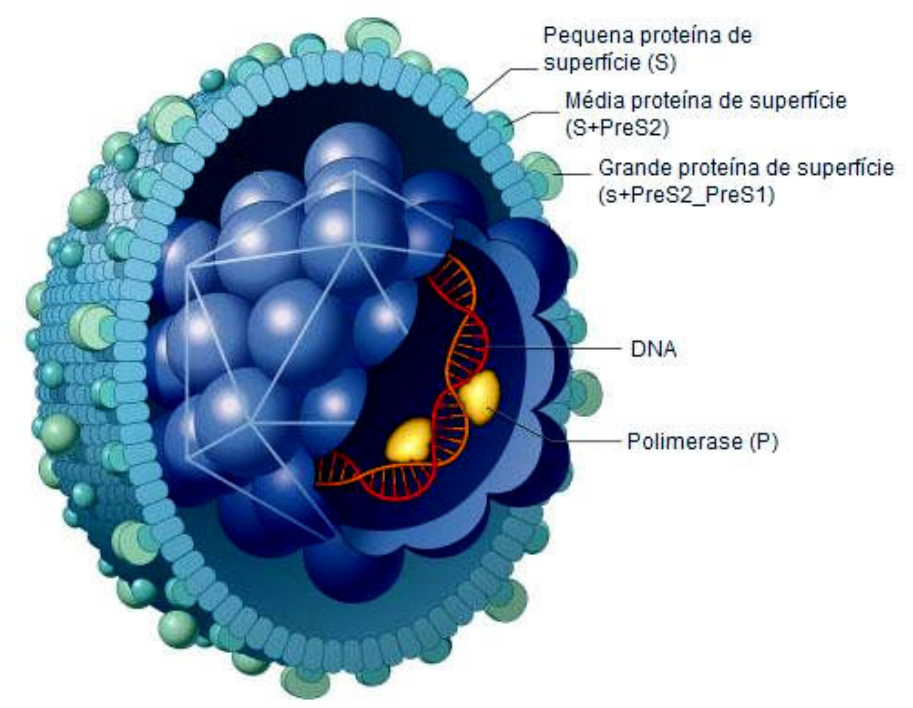

Figura 5 - Esquema do vírus da Hepatite B (Adaptado de PERKINS, J.A., 2007)

Apesar de sermos capazes de produzir anticorpos contra o vírus, eles só funcionam quando o vírus está na corrente sangüínea. Depois que o vírus entra nos 
hepatócitos, os anticorpos não conseguem destruí-lo diretamente. Como partes do vírus são expressos (partes dele aparecem) na membrana que recobre o hepatócito (principalmente o HBcAg), o organismo reconhece estas partes e desencadeia uma inflamação, onde células (principalmente linfócitos $T$ citotóxicos) destroem os hepatócitos infectados. Está iniciada, assim, a hepatite.

De um modo muito simplificado, antígenos (Ag) são substâncias que são capazes de desencadear uma resposta do sistema imunológico. O vírus da hepatite $B$ possui três antígenos principais, o "s" - antígeno de superfície (HBsAg), o "c" - antígeno estrutural (HBcAg) e o "e" - antígeno solúvel (HBeAg).

A vacina para a hepatite $B$ é altamente efetiva e praticamente isenta de complicações (pode causar apenas reações no local da injeção). Como a hepatite B é uma das principais causas de câncer de fígado no mundo, a vacinação não previne apenas a hepatite como também o câncer. Mais de 80 países já adotaram a vacinação de toda a população como estratégia de combate à doença. A vacina consiste de fragmentos do antígeno da hepatite B ( $\mathrm{HBsAg})$, suficiente para produzir anticorpos mas incapaz de transmitir doença.

\subsection{EXPRESSÃO DE GENES HETERÓLOGOS}

A tecnologia do DNA recombinante, surgida no início dos anos 70 , permitiu a adição de fragmento de ácido nucléico em um hospedeiro e a expressão posterior pelo hospedeiro das proteínas codificadas pelo fragmento introduzido. Dentre suas múltiplas aplicações, a produção de vacinas atraiu o interesse de pesquisadores e, em relativamente pouco tempo, obteve-se diferentes sistemas de expressão de vários genes heterólogos. Em geral, o gene de interesse é inserido em um plasmídeo e este é introduzido na célula, a qual se torna então, capaz de transcrever e assim, gerar as proteínas de interesse (SCHATZMAYR, 2001).

Atualmente, diversos vetores genéticos podem ser construídos, visando a produção em larga escala de proteínas ou o estudo do metabolismo celular, como a própria expressão gênica, envolvendo transcrição e tradução, a replicação de DNA e até mesmo mecanismos envolvidos na metagênese e reparo do DNA. 
Os vetores empregados em células eucarióticas podem se integrar ao genoma celular. Esses vetores são constituídos de uma completa unidade de transcrição e um marcador genético (genes que codificam enzimas capazes de conferir resistência a antibióticos ou outras drogas) que permite a seleção de células portadoras do DNA inserido. Esses vetores genéticos podem ainda permitir expressão gênica constitutiva ou indutiva. A utilização de vetores indutíveis permite controlar o período de expressão de um determinado gene pela indução do promotor, como o do gene da metalotioneína (Mt). Já a utilização de vetores constitutivos com o promotor actina (Ac) permite que a expressão seja contínua. Esses vetores, uma vez construídos, devem ser introduzidos em células para expressar o gene heterólogo. Células eucarióticas são interessantes, já que são capazes não só de traduzir as proteínas através da adição de seu respectivo gene, como também de processá-las, realizando alterações pós-traducionais necessárias ao seu bom funcionamento. Assim, o processamento autêntico de proteínas partindo de organismos mais complexos é encontrado em células eucarióticas devido a manutenção nestas de todas as atividades biológicas.

Células de insetos, como a Spodoptera frugiperda (Sf9) têm sido, pelas condições facilitadas de cultura, largamente usadas para a expressão de genes transportados por baculovírus. Este sistema mostra, no entanto, o inconveniente de se constituir num sistema de expressão gênica transiente e não permanente, além de exigir especificamente o sistema derivado de baculovírus (PFEIFER et al., 1997; SUMMERS; SMITH, 1987).

Sistemas de expressão em células de drosófilas têm obtido sucesso em relação aos demais, produzindo um elevado nível de expressão das proteínas heterólogas (BRIGHTY et al., 1991; BUCKINGHAM et al., 1996). Isto se deve, provavelmente, ao uso de eficientes promotores gênicos e ao elevado número de cópias de plasmídeos encontrados por células transfectadas (MCCARROLL; KING, 1997). Assim, estratégias de produção de proteínas têm sido desenvolvidas em células de drosófilas, visando um elevado nível de expressão de genes heterólogos (BENTING et al., 2000; BUCKINGHAM et al., 1996; LEE et al., 2000).

Os antígenos virais, a serem usados como vacina contra a raiva, serão conseguidos através da clonagem dos genes da glicoproteína $G$ do vírus da raiva (GPV) em vetores de expressão e da construção de células de dípteros (S2 - Drosophila 
melanogaster) estavelmente transformadas que expressem esses genes de forma constitutiva e indutível (YOKOMIZO et al., 2007).

As linhagens estavelmente transfectadas são geradas pela co-transfecção de vetores contendo o gene da proteína de interesse e um segundo vetor que codifica um gene de resistência para um antibiótico, que é usado para seleção das células transfectadas. Na construção indutível (pMt/GPV), o gene GPV (glicoproteína G do vírus da raiva) está sob controle de um promotor de metalotioneína (Mt) de expressão indutível com metal (sulfato de cobre) e, na construção constitutiva (pAc/GPV), o gene GPV está sob controle da actina (Ac) de expressão constitutiva. Cada vetor é co-transfectado com o vetor de seleção pCoHygro, que contém o gene de resistência à higromicina (YOKOMIZO et al., 2007). A GPV recombinante é expressa principalmente em lisados celulares e em menor quantidade no sobrenadante.

A transfecção constitui na introdução de um vetor genético em uma célula hospedeira e as condições ideais de cada transfecção devem ser estabelecidas através da adaptação dos protocolos de transfecção já existentes (GUY, 1997).

Para facilitar a penetração do DNA no interior das células, sua transferência dentro do núcleo e possivelmente no genoma, vários métodos de transfecção, com uma variedade de protocolos, têm sido utilizados. Isso reflete a necessidade de aumentar a eficiência de transcrição de genes heterólogos nas células hospedeiras, já que após a transfecção, a porcentagem de células que expressam a proteína de interesse é geralmente baixa. Isso se deve ao fato de que na maioria das vezes poucas células recebem o gene heterólogo e ainda assim em pequena quantidade (GUY, 1997). É importante ressaltar que, após a transfecção, o DNA é integrado no genoma de poucas células (mesmo que em quantidades elevadas) e que a eficiência da expressão do gene heterólogo está ligada à região do genoma em que este gene se inseriu. Ou seja, o gene, mesmo que integrado ao genoma celular, pode ficar inativo se localizado em regiões de heterocromatina, uma vez que esta integração constitui em um evento aleatório (GUY, 1997).

Para minimizar tais problemas é imprescindível estabelecer um protocolo eficiente de transfecção. Para isso, é importante o desenvolvimento de um sistema de detecção eficiente para que as células transfectadas ou co-transfectadas possam ser avaliadas fácil e rapidamente quanto à expressão do gene inserido. Assim, 
proteínas luminescentes, como a GFP (green fluorescent protein) que é uma proteína bioluminescente da água viva Aqueorea victoria (PRASHER et al., 1997), são interessantes por serem facilmente detectadas.

A GFP permanece estável na presença de inúmeros denaturantes e proteases, assim como outros fatores como pH e temperatura (WARD et al., 1982). Além disso, vários mutantes da GFP foram obtidos, alguns deles, como a EGFP, não apresentam dependência de temperatura (PATTERSON et al., 1997).

A expressão de genes heterólogos em células S2 utilizando EGFP foi estudada por Santos (2006) para padronizar procedimentos a fim de aperfeiçoar a transfecção e a expressão de GPV nas células de S2.

Outra proteína de interesse biotecnológico expressa em células de drosófila é o antígeno de superfície do vírus da hepatite B (HBsAg) que já foi expresso através da co-transfecção de um vetor sob controle de um promotor da metalotioneína (pMt) juntamente com um vetor de seleção, este constitutivo contendo o gene da dihidrofolato redutase sob o comando do promotor da actina $5 \mathrm{C}$ de drosófilas. $\mathrm{O}$ HBsAg também já foi expresso pela transfecção de um único vetor, este contendo o gene de seleção no próprio vetor. Observou-se com estas abordagens que os clones de células selecionadas expressam o antígeno viral (DEML; WOLF; WAGNER, 1999).

A expressão das proteínas heterólogas em células de drosófila pode variar de acordo com as propriedades estruturais e funcionais da proteína, tornando-se, na maioria das vezes, um sistema eficiente, capaz de permitir o estudo da expressão de genes heterólogos para a produção de imunológicos em larga escala, com possível redução de custos e risco. Para tal, faz-se necessário o estabelecimento de condições apropriadas de multiplicação celular e expressão gênica (SANTOS, 2006), assim como formulações adequadas de meio de cultura e melhores condições de cultivo em biorreatores. 


\subsection{SISTEMAS DE TRANSFERÊNCIA DE OXIGÊNIO EM BIORREATORES}

Com relação ao cultivo, existe uma grande similaridade entre células animais, bactérias, leveduras e fungos, apesar das células animais originarem-se de tecidos superiores. Porém, em relação às características, as células animais são bem distintas dos microrganismos: crescimento mais lento, maior fragilidade celular e necessidades nutricionais mais complexas (AUGUSTO; OLIVEIRA, 2001).

Um dos principais problemas para a ampliação de escala desse tipo de processo advém das baixas concentrações celulares e de produtos normalmente resultantes desses cultivos (AUGUSTO; OLIVEIRA, 2001). Assim, a meta é a obtenção de concentrações celulares elevadas com um sistema de transferência de oxigênio otimizada para que haja suprimento contínuo de oxigênio, porém equacionando o problema de suscetibilidade das células às tensões de cisalhamento.

Em cultivos celulares podemos considerar o oxigênio como um nutriente do meio de cultura, onde a dificuldade está no fornecimento de oxigênio em vista de sua baixa solubilidade, necessitando ser constantemente fornecido. A solubilidade do oxigênio em água é de $7,00 \mathrm{mg} / \mathrm{L}$ a $29^{\circ} \mathrm{C}$ e $700 \mathrm{mmHg}$ segundo a U.S. Geological Survey, (2006).

O consumo de oxigênio em células animais varia em um amplo intervalo, com valores de velocidade específica de respiração entre 1,4 até $12,5.10^{-17} \mathrm{~mol} /$ (cel.s)

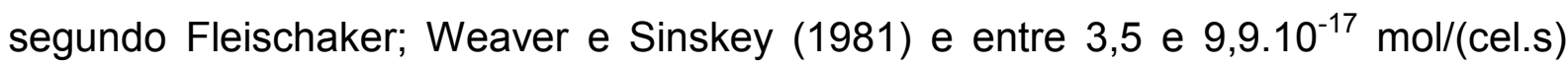
segundo Kioukia et al. (1995) para células de Spodoptera frugiperda (Sf9) em meio TC100. Porém, para células de Spodoptera frugiperda (Sf21) infectada com baculovírus, encontrou-se valores entre 0,8 e 3,8.10-17 $\mathrm{mol} /$ (cel.s) (DEUTSCHMANN; JÄGER, 1994), sendo que, pela literatura, sabe-se que células infectadas possuem uma velocidade específica de respiração mais alta que células não infectadas. Portanto, a velocidade específica de respiração depende da linhagem da célula, do seu estado fisiológico e também do meio de cultura.

Dois grandes problemas aparecem quando se trata de cultivo de células de inseto em suspensão: a fragilidade das células e o suprimento de oxigênio, daí a necessidade de estudo do tipo de sistema de aeração: superficial, aspersão, micro- 
aspersão ou por difusão em membrana de silicone. Abaixo uma breve descrição desses métodos:

- Aeração superficial: onde o gás é insuflado na cabeça do reator. Como a única superfície de troca é a superfície do líquido, este deve ser agitado com boa velocidade para proporcionar uma maior transferência, porém essa agitação pode diminuir a viabilidade celular;

- Aeração por aspersão: no qual o gás é insuflado no meio de cultura, provocando bolhas. Neste sistema pode-se modular a transferência de oxigênio, variando-se sua vazão, fração de oxigênio e também a freqüência de agitação. O rompimento das bolhas geradas ocasiona espuma e estresse às células;

- Micro-aspersão: é a aspersão feita através de um dispositivo que diminui o tamanho das bolhas para dimensões menores de $1 \mathrm{~mm}$. Este dispositivo pode ser um filtro de aço ou vidro sinterizado. A diminuição do tamanho das bolhas aumenta a eficiência específica da aeração, pois bolhas menores apresentam, em um mesmo volume de gás, uma maior área de transferência que bolhas maiores. A modulação da transferência de oxigênio é igual à aspersão (MARQUES, 2005);

- Difusão por membrana: é cada vez mais comum a sua utilização no cultivo de células animais, uma vez que o oxigênio se difunde através da membrana para o meio sem ocasionar danos, pois introduz mínimas forças de cisalhamento. Estas membranas são feitas de materiais como silicone ou teflon, que têm uma alta permeabilidade a oxigênio e gás carbônico, levando a uma alta velocidade de transferência entre a membrana e o meio de cultura no biorreator. A tubulação tem um pequeno diâmetro e vários metros de tubo podem ser instalados no reator, resultando em uma grande superfície de troca de gases entre o tubo e o reator (QI et al., 2003). O sistema de transferência de oxigênio por difusão em membranas de silicone propicia, com grande vantagem sobre a aspersão direta, um ambiente livre de bolhas, que em muitos casos causam danos às células animais (TONSO, 2000). 


\subsection{EQUACIONAMENTO DO SISTEMA DE TRANSFERÊNCIA DE OXIGÊNIO}

O sistema de transferência de oxigênio foi amplamente discutido por Schmidell (2001) e neste trabalho serão tratados alguns tópicos de maior relevância.

A variável de controle mais problemática em um sistema fermentativo aeróbio é o oxigênio dissolvido no meio de cultura, devido a sua baixa solubilidade e à sua dinâmica muito rápida. Devido ao estresse por cisalhamento causado à célula, tentase evitar a utilização de sistemas de transferência de oxigênio através de bolhas de gás devido à ruptura das bolhas de gás na superfície do líquido.

Um sistema empregado que seja livre de bolhas é a difusão por membrana de silicone, onde a membrana, com vários metros de comprimento, é enrolada dentro do reator. A transferência é causada por difusão de oxigênio pela membrana de silicone, devido à diferença entre a pressão parcial de oxigênio interna (dentro da membrana) e externa (meio de cultura) ao tubo. Como a concentração de oxigênio no reator é muito menor que aquela equivalente no tubo, gera-se uma elevada força motriz, responsável pela rápida difusão de oxigênio através da membrana de silicone.

Como o oxigênio é suprido na fase gasosa, então a transferência de oxigênio ocorre entre uma interface gás-líquido, sendo necessário que este oxigênio seja transferido da fase gasosa para o líquido e chegue até as células, penetre nelas e, finalmente, seja consumido. Este caminho apresenta resistências associadas às diferentes concentrações locais presentes no ambiente da cultura e barreiras físicas que o oxigênio enfrenta. Na Figura 6 ilustra-se algumas dessas possíveis resistências.

Esta questão pode ser dividida em três problemas distintos. O primeiro diz respeito à dissolução do oxigênio no líquido, o segundo ao transporte do oxigênio até a célula e o terceiro ao consumo do oxigênio pela célula. Neste segundo problema (resistência 4), o transporte do oxigênio já dissolvido até a célula pode ser desprezado, desde que o líquido seja suficientemente agitado, a fim de que possa ser feito o transporte convectivo. Em relação à transferência convencional por aspersão, há no caso de aeração por membrana de silicone uma etapa a mais (chamada de 1') entre (1) e (2), representando a difusão através da membrana. Porém, os dados de literatura sobre 
a permeabilidade da membrana ao oxigênio são muito contraditórios (LEE; HUANG; LEE, 1990).

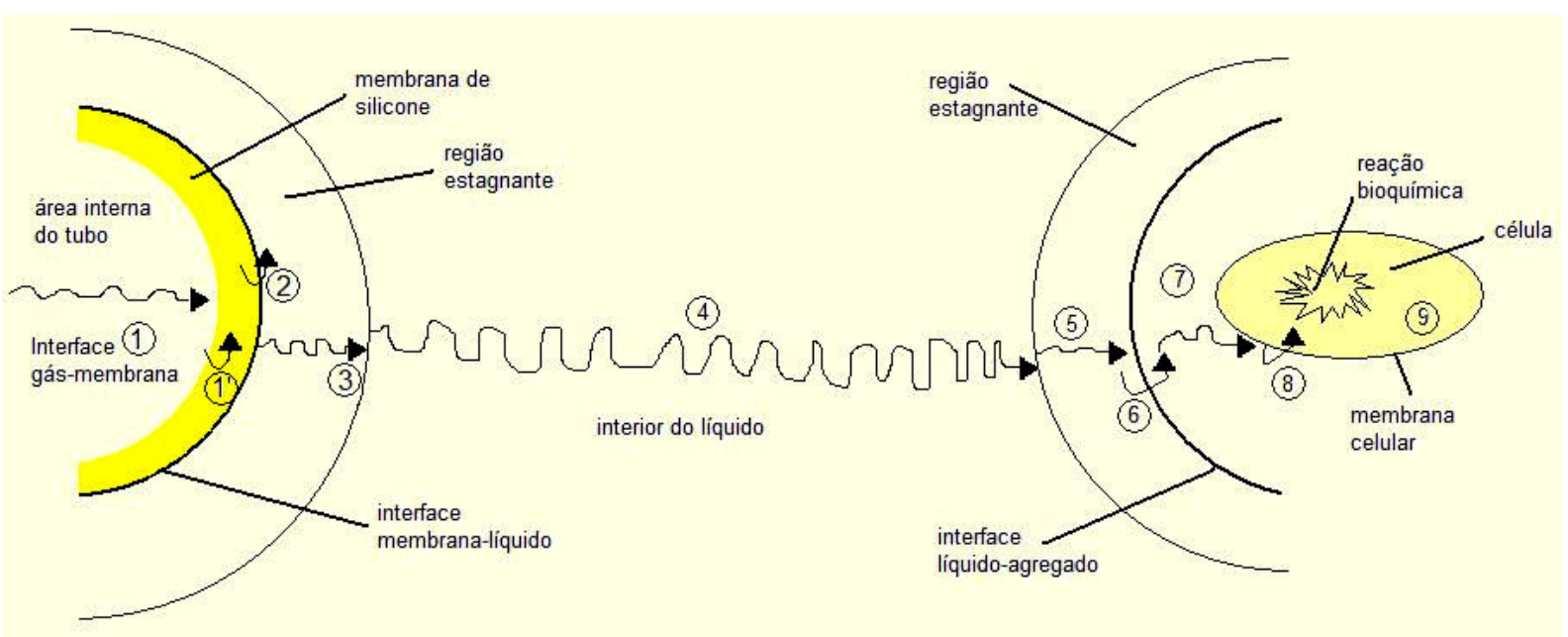

Figura 6 - Resistências associadas ao transporte de oxigênio (Adaptado de SCHMIDELL, 2001).

$\mathrm{Na}$ dissolução do oxigênio na fase líquida, três resistências estão presentes. A resistência (1) se refere a uma película de gás estagnada, através da qual o oxigênio deve se difundir. A resistência (2) é a provocada pela passagem pela interface. A resistência (3) é devida à película estagnada de líquido que está ao redor da bolha. A resistência (1) pode ser desprezada pela intensa movimentação das moléculas de oxigênio no gás. A resistência (2) também pode ser desprezada, pois não é muito significativa.

No lado do consumo de oxigênio, pode-se imaginar uma resistência (5) devido à película líquida em torno da célula, outra devido à resistência imposta pela membrana celular (6), a resistência devido à difusão do oxigênio no citoplasma (7) e, por fim, a associada à velocidade da reação de consumo final deste oxigênio (8).

Como as células possuem dimensões diminutas e existe uma enorme área exposta ao meio líquido, a resistência (5) pode ser desprezada. Também a resistência (6) pode ser desprezada, pois a membrana celular não opõe resistência significativa à difusão do oxigênio. A resistência (7) também é pouco significativa devido à elevada área exposta pela célula ao meio ambiente. Portanto, a parte mais importante em um sistema de transferência de oxigênio reside em obter-se uma eficiente dissolução do oxigênio no meio líquido para que as células possam consumi-lo de forma plena. 
Assim, o equacionamento da transferência de oxigênio leva em conta a soma das resistências importantes e um coeficiente de transferência global.

Define-se $\mathrm{k}_{\mathrm{L}}$ a como o coeficiente volumétrico de transferência de oxigênio $\left(\mathrm{h}^{-1}\right)$, onde "a" é a área específica da superfície de transferência (bolha - área interfacial de transferência de massa dividido pelo volume total de líquido) e $\mathrm{k}_{\mathrm{L}}$ é o coeficiente de transferência de massa da película líquida, que é dependente da difusividade do oxigênio e da espessura das películas estagnadas. Sendo C a concentração de oxigênio no líquido e $C_{s}$ a concentração de oxigênio no líquido que está em equilíbrio com o gás de aeração, tem-se que a variação de $C$ devido à transferência da concentração de oxigênio dissolvido no meio de cultura é dada por:

$$
\frac{d C}{d t}=k_{L} a \cdot\left(C_{S}-C\right)
$$

Esta equação é muito interessante, pois permite uma correta compreensão das formas possíveis para o controle do oxigênio dissolvido. Aumentando-se a pressão parcial de oxigênio no gás de aeração, seja pelo enriquecimento com oxigênio puro ou pelo aumento da pressão na fase gasosa, aumenta-se a transferência de oxigênio devido ao aumento de $C_{s}$ e conseqüentemente da força motriz $\left(C_{s}-C\right)$. Aumentando-se a agitação temos um aumento da velocidade de transferência devido a dois aspectos: a diminuição da espessura da película estagnada, que aumenta o $\mathrm{k}_{\mathrm{L}}$, e o aumento da área específica "a" devido à divisão das bolhas. Da mesma forma, um dispositivo que produza bolhas pequenas, como um filtro de aço sinterizado, provoca um aumento da área, resultando em um aumento global do $\mathrm{k}_{\mathrm{L}} \mathrm{a}$ e por conseqüência um aumento da transferência de oxigênio.

\subsection{RESPIRAÇÃO CELULAR}

Para se definir um modelo matemático para o consumo de oxigênio, primeiramente precisa-se definir a velocidade específica de respiração $\left(Q_{02}\right)$ como sendo a velocidade que cada célula respira, expressa em $\mathrm{mol} \mathrm{O}_{2} /$ (cel.s).

O Q fisiológico da célula. A curva de $Q_{02}$ como função de C apresenta uma saturação, ou 
seja, a partir de certa concentração de oxigênio dissolvido, $Q_{02}$ é relativamente constante e máximo, e em valores menores que esta concentração, $Q_{02}$ começa a diminuir. Esta concentração é chamada de concentração crítica $\left(C_{\text {crit }}\right)$. As concentrações críticas para células de inseto costumam ser menores que $10 \%$ da saturação com ar (AGATHOS, 1996). Estes valores são característicos de células que crescem isoladamente (SCHMIDELL, 2001).

A Figura 7 ilustra a variação de $\mathrm{Q}_{\mathrm{O} 2}$ com a concentração de oxigênio dissolvido no meio. Nessa figura observa-se que acima de uma dada concentração de oxigênio dissolvido, definida como concentração crítica $\left(C_{\text {crit }}\right)$, o valor de $Q_{02}$ é constante e máximo. Isso significa que o dimensionamento de um sistema de agitação e aeração, caso se tenha o objetivo de permitir a máxima velocidade específica de respiração (o que é freqüente), deve-se buscar a manutenção da concentração de oxigênio dissolvido acima da concentração crítica, a fim de que o oxigênio não seja limitante.

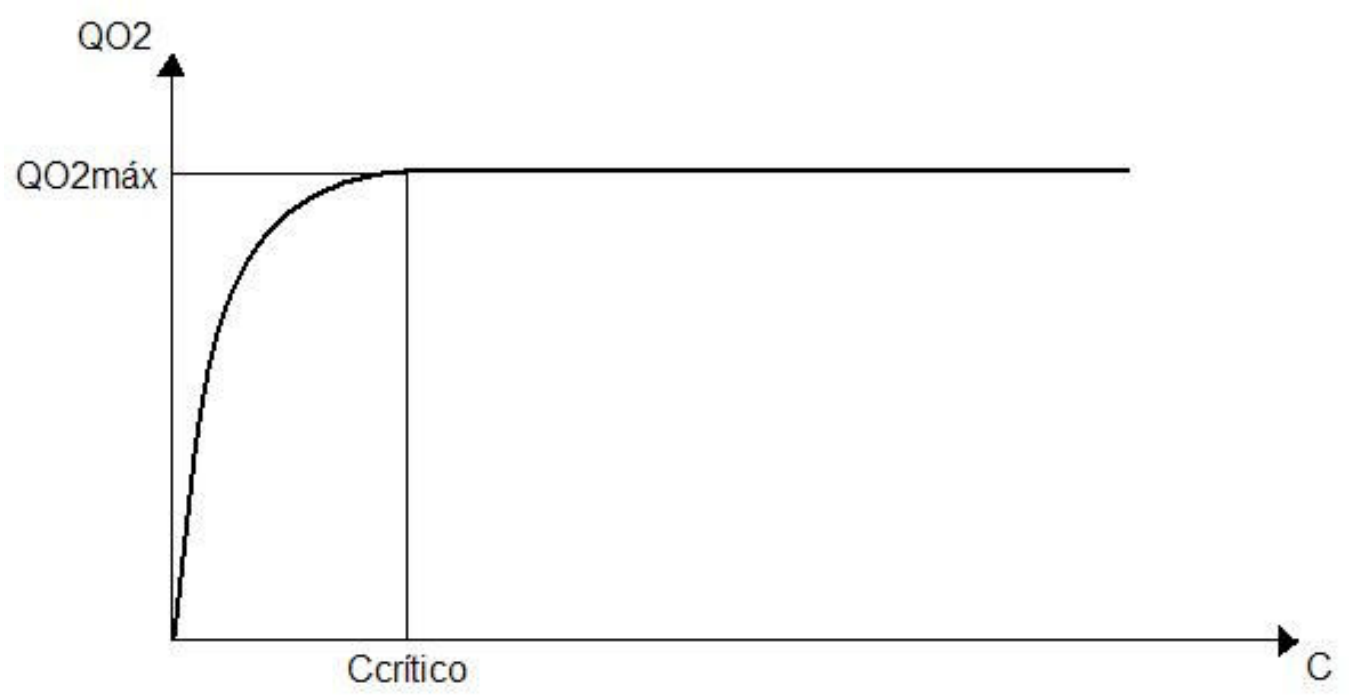

Figura 7 - Representação esquemática da variação de $Q_{02}$ com C (Adaptado de SCHMIDELL, 2001)

O valor de $\mathrm{C}_{\text {crit }}$ é costumeiramente apresentado em porcentagem da saturação com ar, valor este que pode ser lido diretamente do eletrodo de oxigênio.

O consumo total de oxigênio em um dado instante em um cultivo de células é dado pela velocidade específica de respiração $\left(Q_{\mathrm{O} 2}\right)$, multiplicada pela concentração celular (X). Este produto é conhecido como OUR (Oxygen Uptake Rate) e é expresso em mols de oxigênio, por segundo, por litro de cultura. Outra forma comum 
de expressar OUR é em mmol de oxigênio, por hora, por litro de cultura (MARQUES, 2005).

$$
\text { OUR }=Q_{\mathrm{O}_{2}} \cdot X
$$

onde: $\mathrm{Q}_{\mathrm{O} 2}=$ velocidade específica de respiração $\left(\mathrm{molO}_{2} /(\right.$ cel.s $\left.)\right)$

$\mathrm{X}=$ concentração celular $(\mathrm{cel} / \mathrm{mL})$

OUR = velocidade de consumo de $\mathrm{O}_{2}\left(\mathrm{molO}_{2} /(\mathrm{mL} . \mathrm{s})\right)$

Durante um cultivo de células em um biorreator, efetua-se a transferência de oxigênio ao mesmo tempo em que ele é consumido pelas células. Desta forma, o equacionamento mais adequado é um balanço do oxigênio no meio líquido dado por:

$$
\frac{d C}{d t}=k_{L} a \cdot\left(C_{S}-C\right)-O U R
$$

Esta equação indica que a variação de oxigênio dissolvido no meio de cultura (dC/dt) é resultado da diferença do que é transferido $\left(\mathrm{k}_{\mathrm{L}} \mathrm{a}\left(\mathrm{C}_{\mathrm{s}}-\mathrm{C}\right)\right)$ e do que é consumido pelas células (OUR).

No início do cultivo, a concentração das células é baixa resultando em uma baixa OUR e pouca necessidade de transferência de oxigênio. Com a cultura em fase exponencial e o número de células aumentando, a OUR aumenta e por conseqüência aumenta a necessidade de transferência de oxigênio. A OUR máxima é alcançada instantes depois do fim da fase exponencial, onde embora o Qo2 não seja máximo, uma maior concentração celular é responsável por esta máxima OUR. Como se mantém $C>C_{\text {crit }}, Q_{02}$ é constante durante a fase exponencial, decaindo depois do término desta. Nos cultivos com $\mathrm{k}_{\mathrm{L}}$ a e $\mathrm{C}_{\mathrm{s}}$ constantes, é nesse instante que se tem o menor valor de C. Com o fim do crescimento e o decréscimo do $Q_{02}$, a OUR diminui progressivamente.

Para determinação do $\mathrm{k}_{\mathrm{L}}$ a num sistema sem células, pode-se acompanhar a medida de $C$ através de um eletrodo após a alteração na composição do gás adicionado ao sistema. Ou seja, a partir de uma situação de equilíbrio, mudando-se a composição da mistura do gás, altera-se $C_{s}$ e pode-se medir $k_{L}$ a pela variação de $C$ com o tempo (SCHMIDELL, 2001). 
Já num cultivo, na presença de células respirando, pode-se utilizar o Método Dinâmico. Conforme a Figura 8, em um dado instante da cultura $\left(\mathrm{t}_{0}\right)$, interrompe-se o fornecimento de oxigênio e se reduz a freqüência de agitação, de forma a tornar desprezível a transferência de oxigênio, porém este procedimento é verdadeiro quando se trabalha em reatores com aspersão. Já no caso de reatores com difusão por membrana de silicone necessita-se pensar em uma outra maneira de efetivar essa interrupção do fornecimento de oxigênio, uma vez que o interior da membrana de silicone está com uma alta fração de oxigênio.

A concentração de oxigênio começa a diminuir devido ao consumo pela respiração, sendo continuadamente registrada. Após alguns instantes $\left(\mathrm{t}_{1}\right)$, com a concentração de oxigênio dissolvido $\mathrm{C}_{01}$, retoma-se a condição de transferência de oxigênio que estava sendo empregada anteriormente. Assim, a concentração de oxigênio dissolvido começa a aumentar até atingir o equilíbrio no mesmo valor que estava antes de $t_{0}$.

Este processo deve demorar um tempo relativamente curto, não atingindo a concentração crítica de oxigênio, a fim de não alterar o $Q_{02}$, isto é, $C_{01}>C_{\text {Crit- }}$.

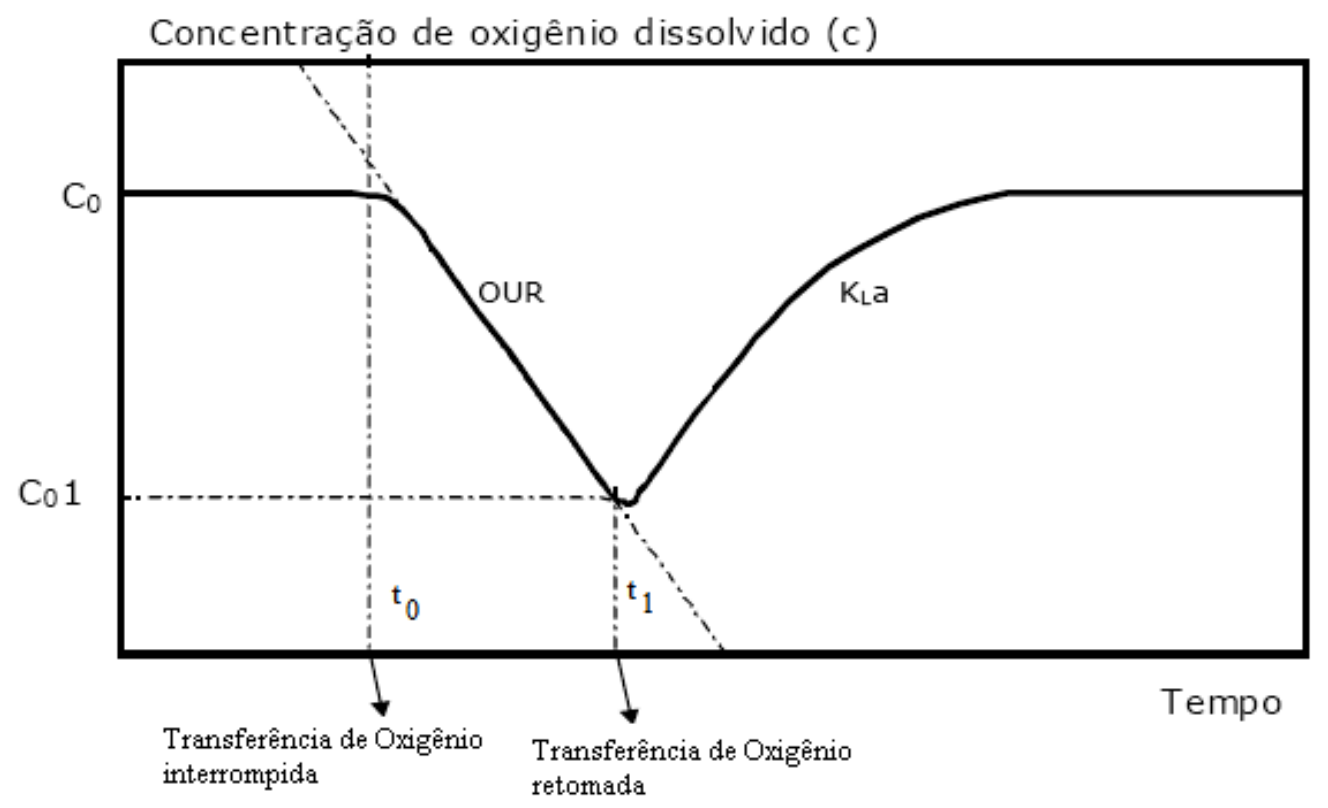

Figura 8 - Perfil do oxigênio dissolvido durante o método dinâmico (Adaptado de SCHMIDELL, 2001)

Desta forma, temos para o trecho sem transferência de $\mathrm{O}_{2}$ :

$$
\frac{d C}{d t}=-Q_{\mathrm{O}_{2}} \cdot X
$$


Então, sendo a OUR constante no intervalo medido, tem-se que ela é igual ao coeficiente angular. Com o valor de OUR e medindo-se a concentração celular no mesmo instante, pode-se calcular o valor de $Q_{02}$.

Pode-se calcular o k $\mathrm{L}$ a utilizando-se o trecho ascendente da medida dinâmica. Para isto, é utilizado o coeficiente angular do gráfico dado pela equação (SCHMIDELL, 2001):

$$
\ln \left(\frac{C_{0}-C}{C_{0}-C_{01}}\right)=-k_{L} a \cdot\left(t-t_{1}\right)
$$

Outra maneira de se calcular o k $\mathrm{L}$ a consiste em se imaginar que a concentração de oxigênio dissolvido ao longo do processo fermentativo, varia muito lentamente, esperando-se que ao final da aplicação do método dinâmico, a concentração de oxigênio dissolvido volte ao valor original $\mathrm{C}_{0}$. Nesta situação, pode-se considerar $(\mathrm{dC} / \mathrm{dt})=0$, o que aplicado na equação de balanço de oxigênio no meio líquido fornece:

$$
k_{L} a=\frac{Q_{\mathrm{O}_{2}}}{\left(C_{s}-C_{0}\right)}
$$

Esta metodologia de cálculo apenas deve ser aplicada para os instantes em que já se tenham valores de $C_{0}$ razoavelmente abaixo de $C_{s}$ (por exemplo, valores de $C_{0}<$ $\left.0,8 \mathrm{C}_{\mathrm{S}}\right)($ SCHMIDELL, 2001).

\subsection{MONITORAMENTO E CONTROLE DE CULTURAS EM BIORREATORES}

Através do monitoramento das variáveis que influem no cultivo de culturas de insetos $(\mathrm{pH}$, temperatura, oxigênio dissolvido, concentração celular e viabilidade celular) podem ser tomadas ações para a manutenção das melhores condições de processos e obtenção de altas produtividades. 


\subsubsection{Oxigênio dissolvido, pH e temperatura}

Oxigênio dissolvido, pH e temperatura são parâmetros comumente monitorados no cultivo de células de inseto, pois estão disponíveis nos sistemas de biorreatores mais comuns. A medida de temperatura é mais comumente feita por termorresistores tipo Pt100, sem contato com o meio de cultura, sendo o ponto de tomada da temperatura em um poço que, devido a uma grande superfície de troca de calor, reflete a temperatura do meio de cultura. Já o $\mathrm{pH}$ e o oxigênio dissolvido são medidos por sondas autoclaváveis, que mantém contato direto com o meio de cultura (MARQUES, 2005).

\subsubsection{Concentração, viabilidade celular e metabólitos}

A concentração e a viabilidade celular são em geral realizadas de modo off-line, utilizando-se hemacitômetros ou contadores tipo Coulter. A amostragem e a contagem das células é um trabalho de difícil automatização.

A concentração de metabólitos como glicose, lactato, glutamina e amônio, também costuma ser medida off-line, em amostras de cultura clarificadas (livres de células).

\subsection{BIORREATORES PARA CULTIVO DE CÉLULAS DE INSETO}

Para a produção em larga escala de células de inseto é necessária a utilização de equipamentos apropriados como os biorreatores. Entre as décadas de 70 e 80, intensificaram-se as pesquisas no desenvolvimento de biorreatores para cultivos de células animais e devido às suas necessidades em relação à agitação e aeração, vários tipos de reatores foram desenvolvidos.

O escalonamento do cultivo de células de insetos em biorreator é dependente da transferência adequada de oxigênio. Devido à sua baixa solubilidade em água, o oxigênio necessita ser continuamente suprido ao meio líquido, a fim de suprir a necessidade celular e, de maneira suave, para evitar danos por cisalhamento. 
É mais frequentemente utilizado o reator de tanque agitado, devido ao seu tamanho e versatilidade. Projetos de biorreatores deste tipo incluem o uso de fermentadores de fundo redondo e a prevenção de regiões de vórtices para não provocar danos às células (VAN DER POL; TRAMPER, 1998). O tipo de impelidor (Figura 9) interfere no tipo de fluxo que se obterá no reator (Figura 10).

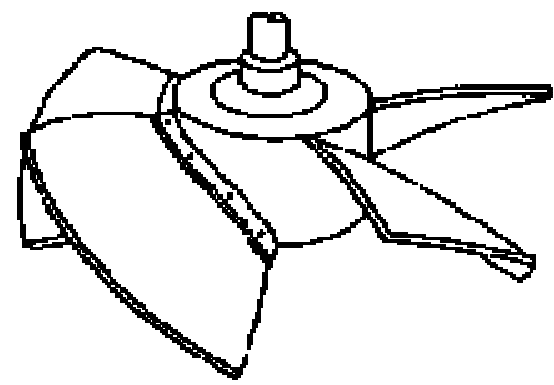

(a)

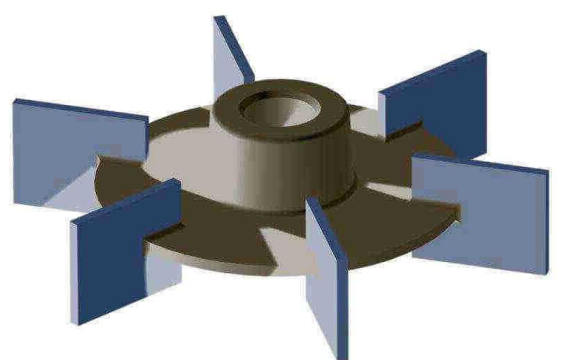

(b)

Figura 9 - Exemplo de impelidores: (a) hélice marinha e (b) pás planas
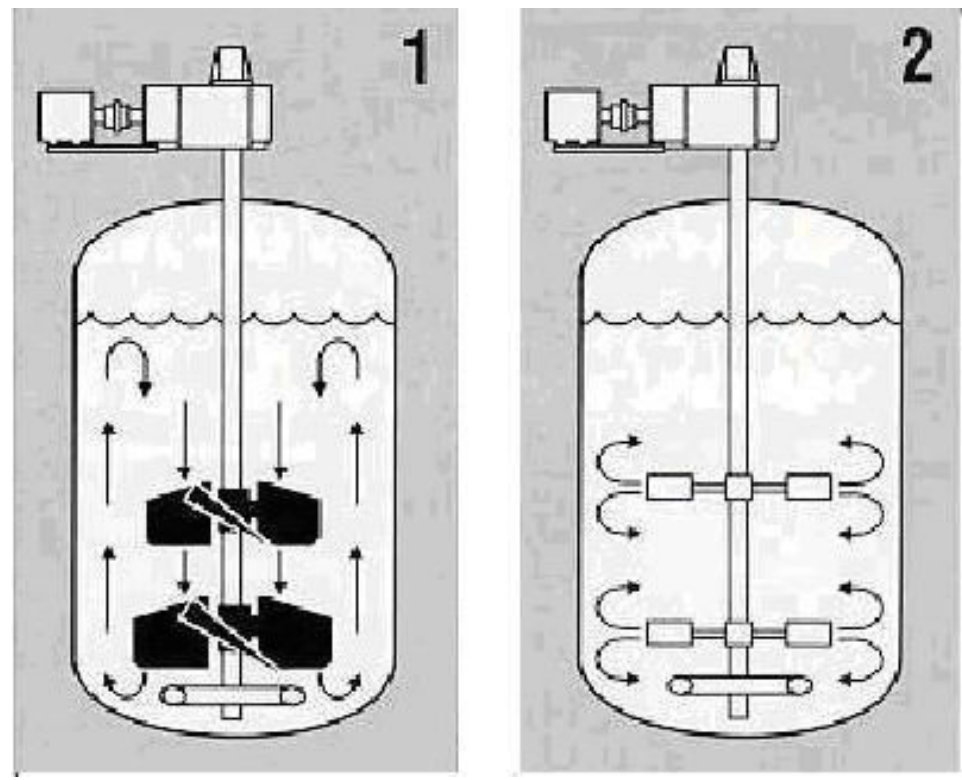

Figura 10 - Exemplo de biorreator de tanque agitado com os impelidores: (1) Fluxo axial com hélice marinha e (2) Fluxo radial com pás planas

Tipos alternativos de biorreatores são mencionados como alternativas para a produção de proteínas recombinantes e bioinseticidas em larga escala (IKONOMOU; SCHNEIDER; AGATHOS, 2003). Dentre os reatores com agitação e aeração podem-se citar ainda os biorreatores de leito fixo e leito fluidizado. Existem também os sistemas com fibras ocas que são empregados para células aderentes e possuem aeração. Para células em suspensão recomenda-se a utilização de reatores do tipo tanque agitado, do tipo airlift e de coluna de bolhas. 
O tipo airlift (CHUNG; TATICEK; SHULER, 1993; RICE et al., 1993) ou tipo colunas de bolha (TRAMPER; VLAK; GOOIJER, 1996) (Figura 11) têm sido usado, em sistemas de culturas em batelada, semi-contínuo (VAN LIER et al., 1996) ou em perfusão (CARON et al., 1994; TONSO, 2000). Estes sistemas de culturas semicontínuo e perfusão visam o fornecimento de nutrientes que são consumidos ao longo de um cultivo.
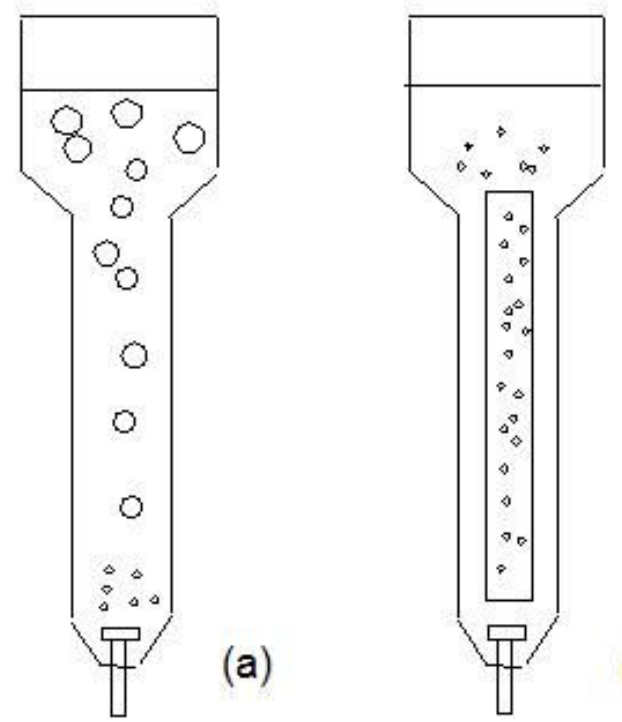

(b)

Figura 11 - Exemplo de biorreatores: (a) Coluna de Bolhas e (b) airlift

Existe ainda o biorreator de ondas wave bioreactor (SINGH, 1999) (Figura 12), que consiste em um sistema com bolsas de polietileno, pré-esterilizadas e descartáveis, que são preenchidas com meio de cultura e células, sendo o restante da câmara preenchido com ar. Estas bolsas são colocadas em uma plataforma que balança continuamente e este balanço gera ondas que garantem a transferência de oxigênio, distribuição de nutrientes e suspensão de células.
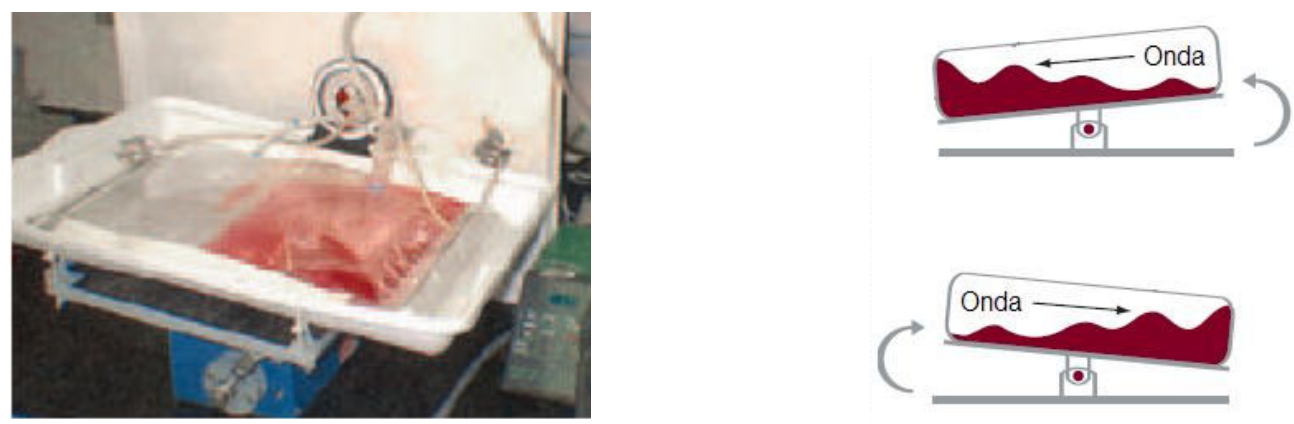

Figura 12 - Exemplo de biorreator de ondas 


\section{MATERIAIS E MÉTODOS}

\subsection{LINHAGEM DE CÉLULAS E MEIO DE CULTURA}

Primeiramente, foram utilizadas neste trabalho células Sf9 (isoladas do ovário de pupa da borboleta Spodoptera frugiperda) de linhagem originalmente obtida da ATCC 1711 (ICB - USP), estando durante ensaio na passagem 98. Esta célula foi descongelada do banco de células congeladas na passagem 85 em meio isento de soro SF900 II (Gibco, Grand Island, NY) com adição de 10\% de soro fetal bovino e $10 \%$ de DMSO (Merck). Em seguida, as células foram mantidas em meio de cultura SF900 II isento de soro.

Posteriormente, foram utilizadas:

- Células S2 selvagem (Invitrogen, isoladas a partir de células isoladas de uma cultura primária de embriões de Drosophila melanogaster em estágios tardios de desenvolvimento) com passagem 57 e 65;

- Células S2 transfectadas com os vetores pAcGPV e pCoHygro (S2AcGPV2) construídas pela Dra. Adriana Yurie Yokomizo (YOKOMIZO et al., 2007) (Figura 13) que expressam constitutivamente a glicoproteína $G$ do vírus da raiva;

- Células S2 transfectada com o vetor pMtEGFP (S2MtEGFP) na passagem 77, construída pela M.Sc. Mariza Gerdulo dos Santos (SANTOS, 2006) (Figura 14), que expressam a proteína EGFP após indução com Sulfato de Cobre $700 \mu \mathrm{M}$;

- Célula S2 transfectada com o vetor pAcHBsAgHy (S2AcHBsAgHy) na passagem 12, construída pela Dra. Soraia Attie Calil Jorge (Figura 15) e que secreta a proteína HBsAg de forma constitutiva, todas do Laboratório de Imunologia Viral do Instituto Butantan. 

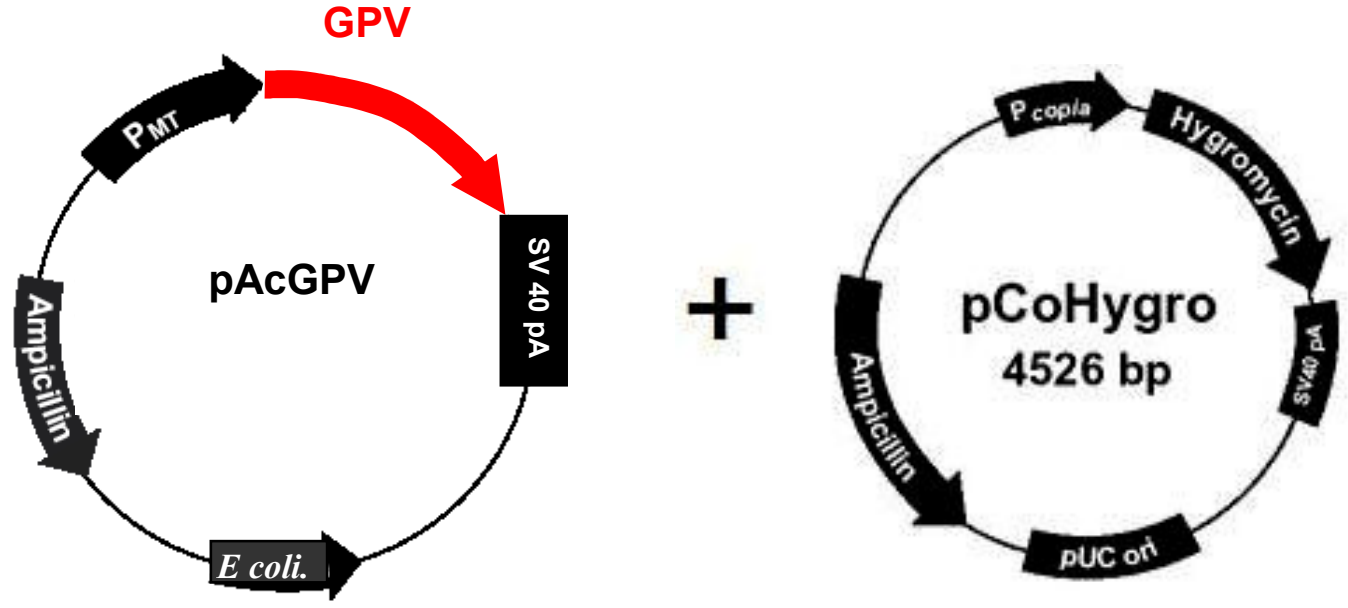

Figura 13 - Mapa do vetor pAcGPV (Adaptado de YOKOMIZO, 2006)

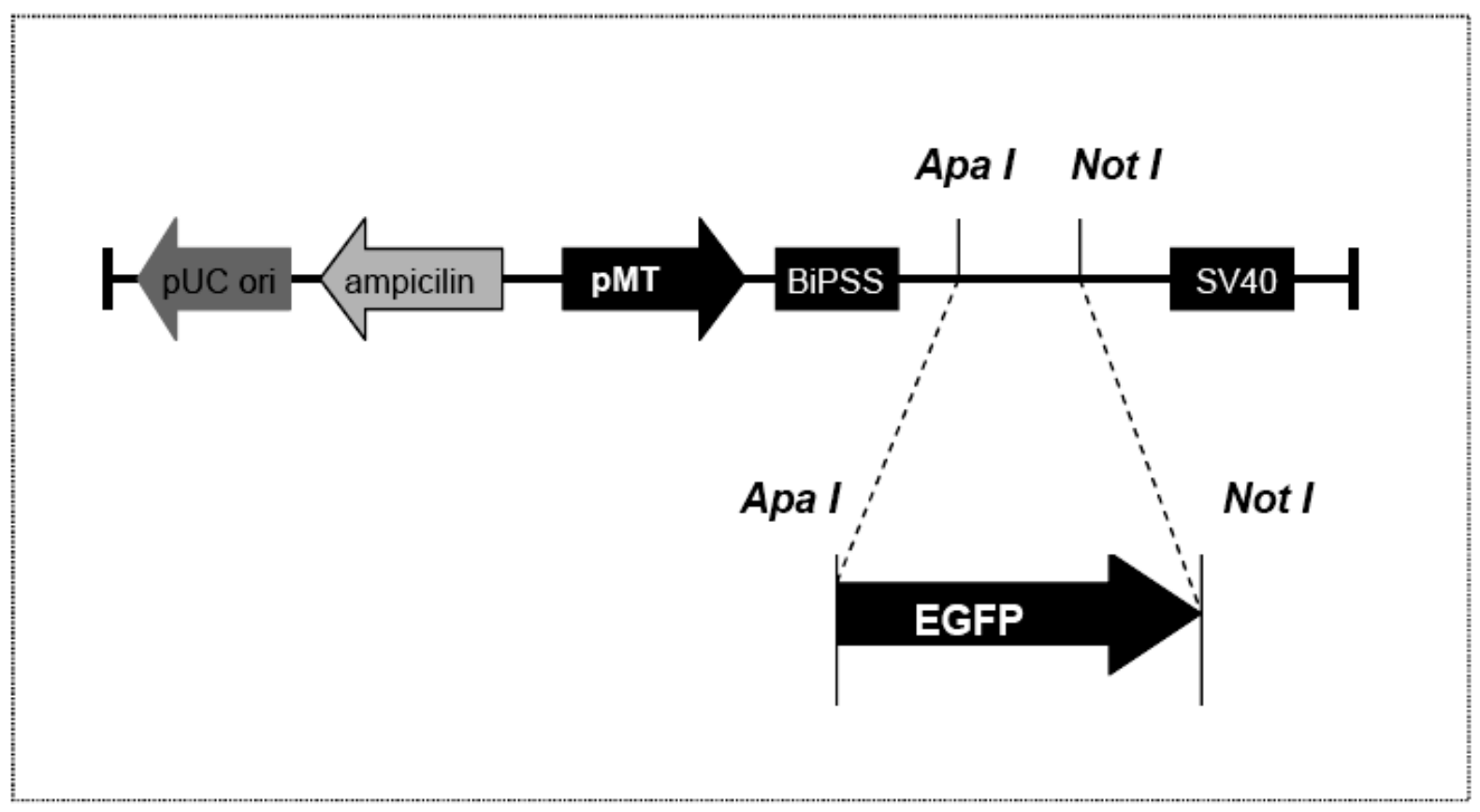

Figura 14 - Mapa do vetor pMtEGFP (Adaptado de SANTOS, 2006) 


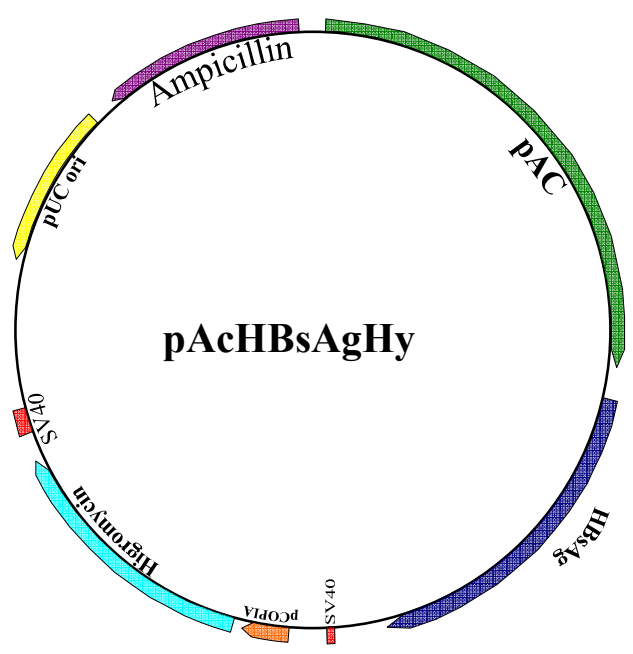

Figura 15 - Mapa do vetor pAcHBsAgHy (Gentilmente cedido por Soraia A.C. Jorge))

O banco de células Sf9 e S2 selvagem e transfectadas é de uso comum com o Laboratório de Imunologia Viral utilizando-se protocolo de congelamento em $40 \%$ de meio isento de soro SF900 II (Gibco, Grand Island, NY), 50\% de soro fetal bovino e $10 \%$ de DMSO (Merck). Para a manutenção das células e preparo do inóculo, até possuírem a concentração necessária para sua utilização em biorreator, foi utilizado o meio de cultura SF900 II (Gibco, Grand Island, NY).

Durante essa manutenção todas as células foram mantidas em frascos tipo Schott (100 $\mathrm{mL}$ de volume total e $10 \mathrm{~mL}$ de cultura de células) em incubador rotativo, 100 $\min ^{-1}$ e a $28^{\circ} \mathrm{C}$, sendo realizados repiques $(1: 4 \mathrm{v} / \mathrm{v})$ a cada $4 / 5$ dias para a manutenção das células em fase exponencial e alta viabilidade. Em todos os ensaios apresentados, usou-se meio SF900 II isento de soro.

\subsection{BIORREATOR E INSTRUMENTAÇÃO ASSOCIADA}

Para a execução dos ensaios foi utilizado o biorreator Inceltech Discovery 100 (Inceltech, França), com dorna de volume total de $2 \mathrm{~L}$ e volume de trabalho de $1 \mathrm{~L} \mathrm{e}$ sistema de controle M.R.U. (Inceltech, França) conforme a Figura 16. Esse sistema conta com controle de temperatura (sensor Pt100, aquecimento por manta externa envolvendo a dorna e resfriamento pela passagem de água fria em uma termo- 
chicana); controle de pH (sonda Mettler Toledo, atuação por acionamento de bomba peristáltica); controle da agitação (sensor de rotação e atuação por motor acoplado a mecanismo de transmissão magnética com pás planas) e controle do oxigênio dissolvido (sonda polarográfica Mettler Toledo com atuação por tempo de abertura de válvula e fluxo controlado por rotâmetro). Foram utilizados os sistemas originais para o controle da temperatura e freqüência de agitação, mantidas constantes em $28^{\circ} \mathrm{C}$ e $100 \mathrm{rpm}$ em todos os ensaios. $\mathrm{O} \mathrm{pH}$ foi apenas monitorado, não sendo utilizada nenhuma intervenção. No caso do controle de oxigênio dissolvido, o sistema original foi substituído por um sistema de atuação de dois fluxômetros conforme descrito no item 3.2.1. O eletrodo de oxigênio foi calibrado em água saturada por ar na temperatura de $28^{\circ} \mathrm{C}$.

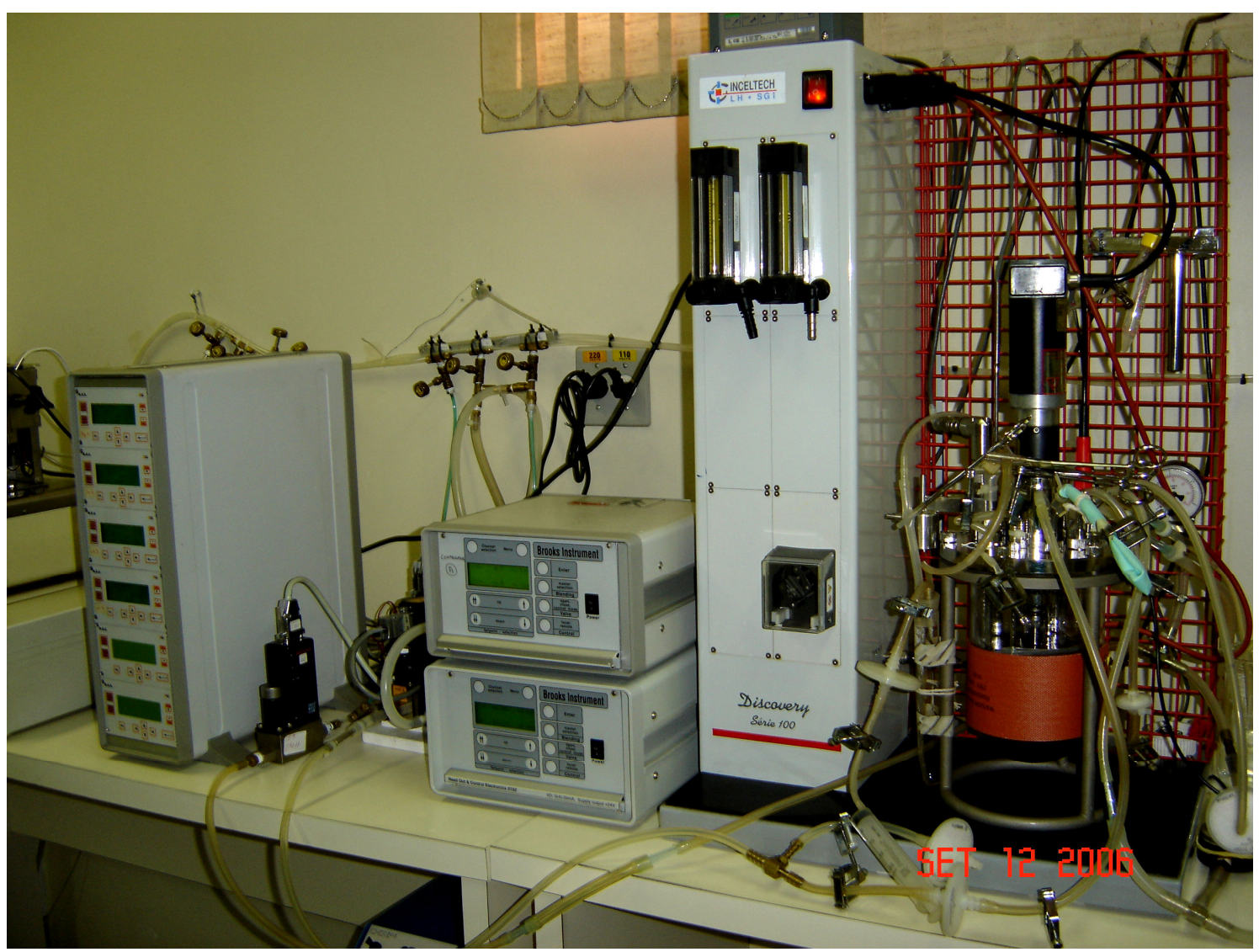

Figura 16 - Foto do biorreator e seus equipamentos

Esse biorreator apresenta ainda duas saídas analógicas ( 0 a $10 \mathrm{~V}$ com resolução de $0,1 \mathrm{~V}$ ) e duas saídas digitais ( 0 ou $24 \mathrm{~V}$ ) para cada módulo de controle. Estas saídas podem ser programadas em função das diferentes variáveis como atuação (para acionar e modular um fluxômetro), medida (para um registrador), entre outras possibilidades. 
O biorreator está conectado a um microcomputador, onde através do software Bioac (Inceltech, França) é feito o registro dos dados. O software permite ainda a programação remota do M.R.U. através do computador.

\subsubsection{Sistema de transferência de oxigênio}

Foi utilizado um par de controladores mássicos de vazão (fluxômetros), modelo 5850EM, da Brooks Instruments (Holand, NL), para a modulação da vazão de gases para transferência de oxigênio. Um fluxômetro (1) possui vazão entre 0 e $50 \mathrm{~mL} / \mathrm{min}$ e o outro (2) entre 0 e $200 \mathrm{~mL} / \mathrm{min}$. Esses fluxômetros são controlados pelo módulo de controle 0152 também da Brooks Instruments, que conta com entrada para controle externo, com faixa para o sinal de entrada entre 1 e $5 \mathrm{~V}$, sendo um sinal de $1 \mathrm{~V}$ para atuação igual a zero e um sinal de $5 \mathrm{~V}$ para atuação igual a $100 \%$. Desta forma, a atuação enviada pelo controlador M.R.U. para o fluxômetro tem a resolução de 40 pontos ( $4 \mathrm{~V}$ da faixa de entrada do fluxômetro dividido pela resolução de $0,1 \mathrm{~V}$ da saída analógica do M.R.U.) e tem portanto, limite superior igual a $40 \%$, ou seja, a atuação varia de 0 (vazão $0 \mathrm{~mL} / \mathrm{min})$ a $40(50 \mathrm{~mL} / \mathrm{min})$.

Como convenção foi utilizado o termo fluxômetro 1 para designar o fluxômetro que recebe o sinal de atuação enviado pelo M.R.U. e fluxômetro 2 para o fluxômetro com vazão fixa. Assim, o fluxômetro 1 será sempre o responsável pelo aumento da transferência de oxigênio (atuação positiva).

Conforme a Figura 17 foi utilizada uma configuração com dois fluxômetros instalados em série, sendo que o fluxômetro 1 ( 0 a $50 \mathrm{~mL} / \mathrm{min}$ ) controla a vazão de oxigênio puro e o fluxômetro 2 controla a vazão total de aeração em um valor fixo de 52 $\mathrm{mL} / \mathrm{min}$. A modulação do controle é feita pela variação de composição do gás de aeração, sendo que para atuação igual a zero, a composição do gás de aeração total seria de $52 \mathrm{~mL} / \mathrm{min}$ de nitrogênio.

A transferência de oxigênio foi realizada através de um tubo de silicone (Medicone 200, Multiplast, Brasil) com diâmetro interno de $3 \mathrm{~mm}$, diâmetro externo de $5 \mathrm{~mm}$ e comprimento de $4,20 \mathrm{~m}$, com superfície em contato com o meio de cultura de aproximadamente $0,13 \mathrm{~m}^{2}$ para o Ensaio 1 . 


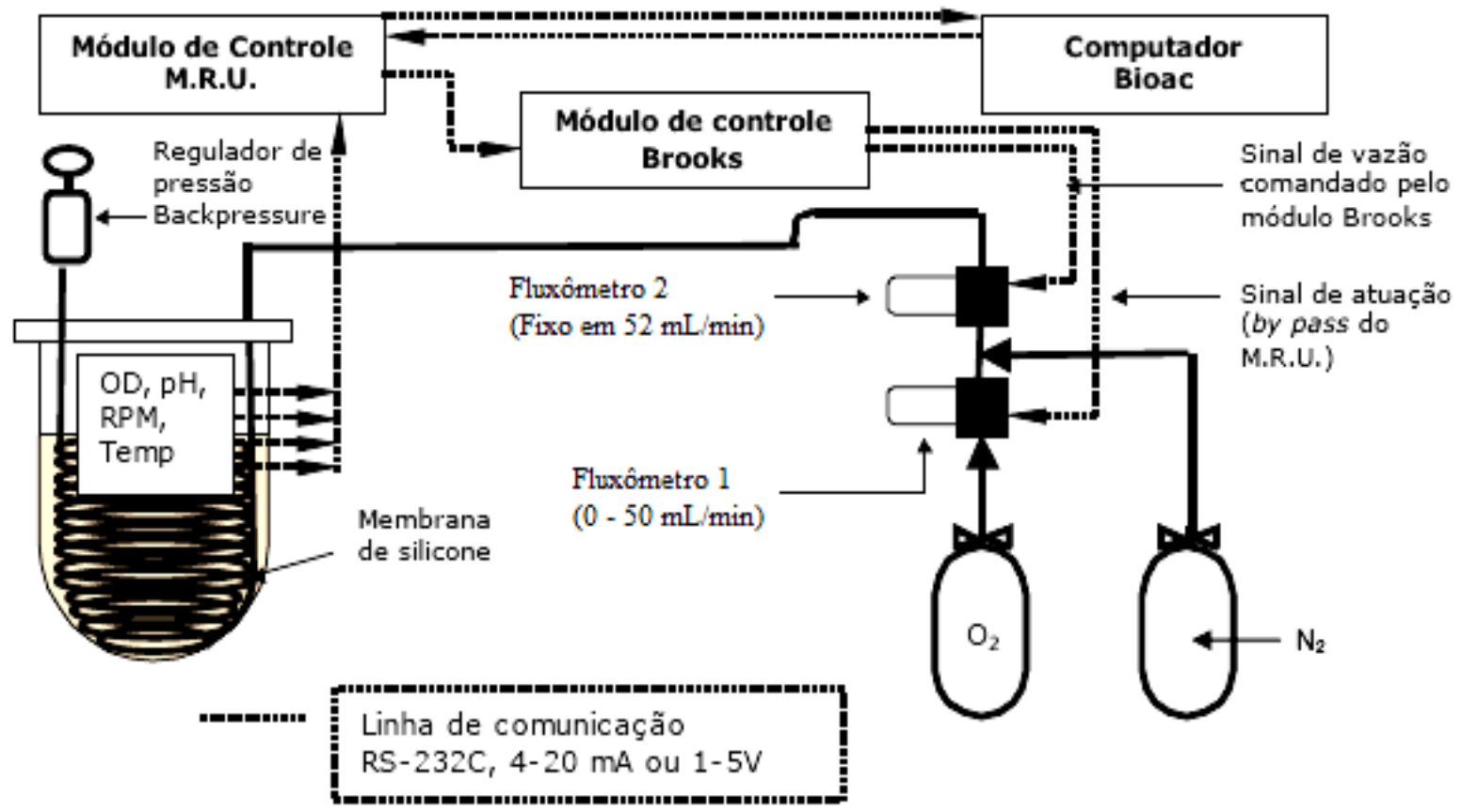

Figura 17 - Esquema da configuração do sistema de transferência de oxigênio (Adaptado de MARQUES (2005)

A partir do Ensaio 2 a transferência de oxigênio foi realizada através de um tubo de silicone (Figura 18) (Silastic RX 50, Laboratory Tubing, Dow Corning Corporation, USA) de diâmetro interno de $2 \mathrm{~mm}$, diâmetro externo de $3,2 \mathrm{~mm}$, porém com comprimento de $8,30 \mathrm{~m}$, tendo, portanto, uma superfície em contato com o meio de cultura de aproximadamente $0,17 \mathrm{~m}^{2}$.

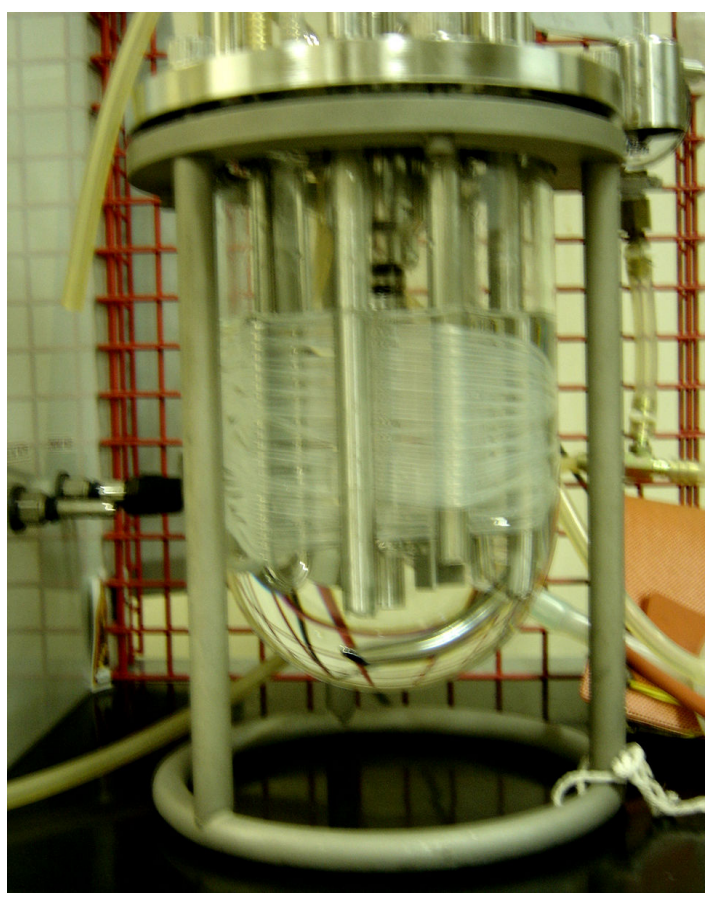

Figura 18 - Foto da membrana de silicone no reator, 
A transferência nesta configuração varia com a pressão parcial de oxigênio no interior do tubo de silicone. A pressão parcial de oxigênio $\left(\mathrm{p}_{\mathrm{O} 2}\right)$ é modulada pela pressão total no interior da membrana $(P)$ e pela fração de oxigênio no gás de aeração $\left(X_{O 2}\right)$ segundo as equações:

$$
\begin{aligned}
& V_{\text {Total }}=52 \quad(\mathrm{~mL} / \mathrm{min}) \\
& V_{g_{1}}=\operatorname{act} .1,25 \quad(\mathrm{~mL} / \mathrm{min}) \\
& V_{g_{2}}=V_{\text {Total }}-V_{g_{1}} \\
& X_{\mathrm{O}_{2}}=\left[\frac{\left(X_{\mathrm{O}_{2} 1} \cdot V_{g_{1}}\right)+\left(X_{\mathrm{O}_{2} 2} \cdot V_{g_{2}}\right)}{V_{\text {Total }}}\right] \\
& \text { como }: X_{\mathrm{O}_{2} 1}=1 \quad\left(\mathrm{O}_{2} \text { puro }\right) e \\
& X_{\mathrm{O}_{2} 2}=0 \quad\left(N_{2} \text { puro }\right) \Rightarrow X_{\mathrm{O}_{2}}=\frac{V_{g_{1}}}{V_{\text {Total }}} \\
& \therefore X_{\mathrm{O}_{2}}=\frac{\text { act.1,25 }}{52} \\
& p_{\mathrm{O}_{2}}=X_{\mathrm{O}_{2}} \cdot P \Rightarrow p_{\mathrm{O}_{2}}=\frac{\text { act.1,25 }}{52} \cdot P
\end{aligned}
$$

Onde: $\mathrm{V}_{\text {Total }}$ é a vazão total limitada de forma fixa pelo fluxômetro $2 ; \mathrm{V}_{\mathrm{g} 1}$ é a vazão do fluxômetro 1 (oxigênio) em função da atuação; act. é a atuação enviada pelo controlador MRU para o fluxômetro; $V_{\mathrm{g} 2}$ é a vazão do gás 2 (nitrogênio); $X_{02} 1$ é a fração de oxigênio no gás $1 ; X_{02} 2$ é a fração de oxigênio no gás 2 e $P$ é a pressão total média no interior na membrana (Apêndice A). A pressão total média é aproximadamente igual à média logarítmica da pressão na entrada do tubo de silicone e da pressão medida na saída do tubo (Ql et al., 2003). A pressão na saída do tubo é regulada por uma válvula 10BP Back Pressure Regulator (Fairchild, Winston-Salen, N.C.), que pode ser regulada de 0,03 a 2,0 bar.

Porém, para que os valores tenham suas unidades coerentes, deve ser aplicada a Lei de Henry, segundo a qual a concentração de oxigênio dissolvido no equilíbrio (saturação) é proporcional à pressão parcial de oxigênio no gás. Para o cálculo de $\mathrm{C}_{\mathrm{s}}$ em $\mathrm{mgO}_{2} / \mathrm{L}$ tem-se: $\mathrm{C}_{\mathrm{s}}=\mathrm{H}$. $\mathrm{p}_{\mathrm{O} 2}$; onde $\mathrm{H}$ é a constante de Henry para um determinado meio e temperatura. 


$$
\begin{aligned}
& C_{s}=H \cdot p_{\mathrm{O}_{2}} \\
& C_{s}=H \cdot \frac{\text { act } 1,25}{52} \cdot P
\end{aligned}
$$

A constante de Henry varia de duas maneiras: a) com a temperatura, pois quanto maior a temperatura menos gás é possível ser dissolvido e b) com o meio de cultura, pois a concentração de oxigênio dissolvido na saturação varia de acordo com a presença de substâncias dissolvidas. Por esse motivo existe na literatura propostas para o cálculo da concentração de saturação, a partir do conhecimento da composição química do meio. Assim, utilizando-se o cálculo sugerido por Schumpe (1986) que a partir da constante de Henry para a água, a uma determinada temperatura, acrescentam-se coeficientes referentes às quantidades das substâncias químicas existentes no meio de cultura, chega-se a um valor da constante de Henry para um determinado meio e temperatura. Desta maneira fez-se o cálculo considerando-se o meio TC100 (Sigma), de formulação conhecida, acrescido de $8 \mathrm{~g} / \mathrm{L}$ de glicose para chegar a um total de $9 \mathrm{~g} / \mathrm{L}$ para se tornar o mais aproximado possível da formulação do que se conhece do SF900ll. Considerando ainda, a temperatura de $28^{\circ} \mathrm{C}$ e $700 \mathrm{mmHg}$, chegou-se a uma constante de Henry de $37,15 \mathrm{mgO}_{2} / \mathrm{L}$.atm, conforme Apêndice B.

Através da Lei de Henry também se calcula $C$ (em mg/L) em função do $O D$, que é um dado retirado diretamente da leitura do eletrodo de oxigênio e, portanto em porcentagem. Assim, através da constante de Henry para o meio SF900 II a $28^{\circ} \mathrm{C} \mathrm{e}$ $700 \mathrm{mmHg}$, tem-se que a solubilidade máxima de oxigênio é de $7,19 \mathrm{mgO}_{2} / \mathrm{L}$ (Apêndice $\mathrm{C}$ ), o que é muito próxima da água, chegando-se a:

$$
C\left(m g_{\mathrm{O}_{2}} / L\right)=O D(\text { leitura do eletrodo }) \cdot \frac{7,19}{100}
$$

Desta maneira, transforma-se a porcentagem de oxigênio dissolvido em $\mathrm{mgO}_{2} / \mathrm{L} \mathrm{e}$ torna-se coerente a principal equação em estudo:

$$
\frac{d C}{d t}=k_{L} a \cdot\left(C_{S}-C\right)-Q_{O_{2}} \cdot X
$$




\subsection{PROTOCOLO DE INOCULAÇÃO DO BIORREATOR}

O pré-inóculo do reator das células Sf9 foi feito a partir de $30 \mathrm{~mL}$ de cultura celular proveniente de três frascos Schotts de $100 \mathrm{~mL}(10 \mathrm{~mL}$ de cultura cada e concentração celular de aproximadamente $5,0 \times 10^{6}$ cel viáveis $/ \mathrm{mL}$ ) e $170 \mathrm{~mL}$ de meio fresco, totalizando $200 \mathrm{~mL}$. Ou seja, tem-se um pré-inóculo com concentração celular inicial de aproximadamente $7,5 \times 10^{5} \mathrm{cel} / \mathrm{mL}$. A cultura é mantida sem agitação (a turbina não alcança o inóculo) com temperatura controlada a $28^{\circ} \mathrm{C}$ e o oxigênio dissolvido é monitorado (não havendo nenhuma renovação de ar no reator). Entre 36 e 48 horas (quando a concentração de oxigênio dissolvido chega perto de $20 \%$ ) a concentração celular é de aproximadamente $2,5.10^{6} \mathrm{cel} / \mathrm{mL}$, quando o volume de trabalho é completado, com meio fresco, para $1000 \mathrm{~mL}$. Obtendo-se assim, uma concentração inicial de aproximadamente $5.10^{5} \mathrm{cel} / \mathrm{mL}$. Este sistema de inóculo adaptado de Marques (2005) apresenta como vantagem a não realização de amostragem periódica para a determinação do momento de início do ensaio. Isto é possível, pois a concentração de oxigênio na fase líquida reflete o consumo global da cultura até aquele momento. Outra vantagem deste protocolo é o fato das células já estarem adaptadas ao ambiente do biorreator no início do ensaio.

Já o inóculo das células de S2 selvagem ou transfectada foi feito em três frascos Schotts de $250 \mathrm{~mL}$ com $25 \mathrm{~mL}$ de cultura cada e cultivado até atingir a concentração celular de aproximadamente $7,0.10^{6}$ cel viáveis $/ \mathrm{mL}$. Estes $75 \mathrm{~mL}$ de cultura foram transferidos para o reator acrescidos de $925 \mathrm{~mL}$ de meio fresco, chegando a concentração celular inicial de aproximadamente $5,0.10^{5} \mathrm{cel} / \mathrm{mL}$. A cultura é agitada a $100 \mathrm{~min}^{-1} \mathrm{com}$ temperatura controlada a $28^{\circ} \mathrm{C}$ e o oxigênio dissolvido é controlado a $40 \%$ da saturação com ar atmosférico. Esta forma de inoculação apresentará uma fase inicial (fase lag) de adaptação ao reator antes de começar efetivamente a crescer. A diferença de preparação do inoculo no reator entre as células Sf9 e S2 é devido ao fato da célula S2 sem agitação, por um longo período, se depositar no fundo do reator. 


\subsection{MÉTODOS ANALÍTICOS}

\subsubsection{Medida de densidade celular}

A medida de densidade celular foi realizada utilizando um hemacitômetro (câmara de Neubauer) e as células foram contadas com a ajuda de um microscópio óptico. A diferenciação entre as células viáveis e não viáveis foi feita através da adição do corante Azul de Tripan com concentração de 0,3 M (Merck). A célula que apresentou sua membrana rompida foi invadida pelo corante, sendo considerada não viável. Para cada amostra foi utilizada $90 \mu \mathrm{L}$ de amostra e $10 \mu \mathrm{L}$ de Azul de Tripan. Quando necessário, a amostra foi diluída em tampão PBS (Gibco, NY) de forma a se obter em torno de 100 a 120 células por campo de amostragem (Figura 19 - campo 1). Foram contados 24 campos para cada amostra, ou seja, 3 lâminas, sendo considerado uma concentração celular a média de 4 campos, resultando em 6 valores de concentração por amostra. Os erros foram calculados para um intervalo de confiança de $95 \%$ (teste $\mathrm{t}$ ).

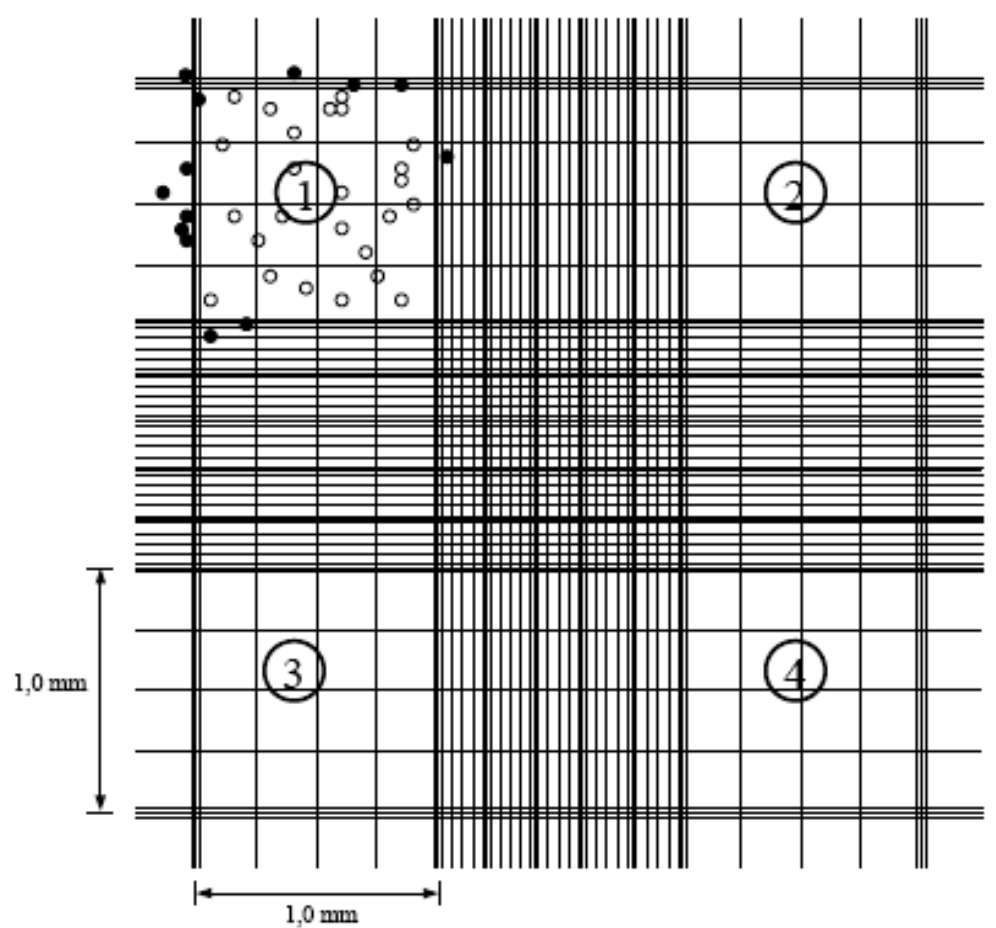

Figura 19 - Esquema de uma Câmara de Neubauer com os campos para contagem da concentração celular 


\subsubsection{Determinação da concentração de glicose, glutamina e lactato}

As amostras provenientes do biorreator foram centrifugadas por 4 minutos e 3000 rpm para a separação das células, e o sobrenadante foi congelado à $-20^{\circ} \mathrm{C}$. Para a determinação das concentrações de glicose, lactato e glutamina foi utilizado um analisador bioquímico Yellow Springs modelo 2700 Select (Yellow Springs Instrument Co., $\mathrm{OH}$ ).

\subsubsection{Dosagem de GPV}

As amostras obtidas no Ensaio com a linhagem S2AcGPV2 foram analisadas em ELISA (Enzyme Linked Immunosorbent Assay). Esse método tem como princípio a imunocaptura. A placa para o ensaio é sensibilizada com anticorpo monoclonal purificado anti glicoproteína da raiva. A GPV, uma vez presente na amostra, se liga a estes anticorpos e posteriormente ao mesmo anticorpo conjugado com peroxidase, produzindo uma reação de cor revelada pelo substrato cromógeno. A concentração de GPV é determinada pela comparação da absorbância da amostra com a absorbância do antígeno para validação do teste com concentração de GPV conhecida.

Utilizou-se como sistema de lise nessa amostragem, 100uL de tampão + Nonidet 1\% + PMSF $1 \mathrm{mM}$, sobre o pellet, incubação a $4^{\circ} \mathrm{C}$ durante $1 \mathrm{~h}$, com agitação periódica, pelo menos a cada 15 minutos. Após a lise, foi adicionado às amostras 900uL de PBS+Tween+BSA (diluente tradicional do padrão GPV utilizado na análise). A amostra foi homogeneizada e centrifugada a 10000rpm durante 5 minutos para separar os debris celulares. O sobrenadante foi aplicado à placa em duplicatas de 200uL cada. 


\subsubsection{Dosagem de EGFP}

As análise das amostras de EGFP durante o cultivo foram feitas no citômetro de fluxo (FACS - Fluorescence Activated Cell Sorter) sob supervisão do Dr. Jorge Mário C. Ferreira Jr. do Laboratório de Imunoquímica do Instituto Butantan.

No citômetro de fluxo os fótons de luz gerados atingem detectores específicos e são convertidos em impulsos elétricos proporcionais ao número de fótons recebidos (Figura 20), ou seja, um raio laser ilumina cada célula individualmente, numa corrente líquida ultrafina. Detectores analisam a luz espalhada e emitida pela fluorescência das células. As células são reconhecidas e selecionadas. Estes impulsos são convertidos em sinais digitais podendo oferecer os resultados em diferentes formas de análise tais como histogramas.

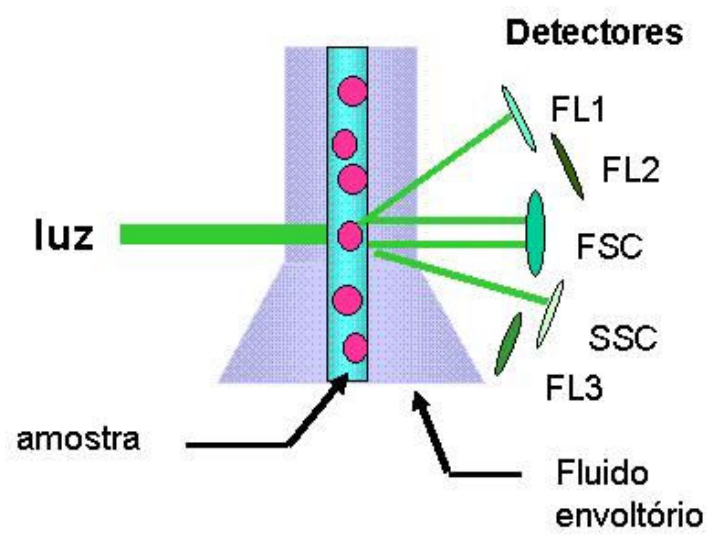

Figura 20 - Esquema de funcionamento de um citômetro de fluxo (Adaptado de INSTITUTO FLEURY, 2007)

$\mathrm{Na}$ análise feita em citometria de fluxo foram adquiridos 10.000 eventos para cada amostra analisada, sendo que os eventos considerados foram aqueles que compõem a população homogênea da amostra. As análises foram realizadas em um aparelho FACSCALIBUR da Becton Dickingson. O citômetro de fluxo foi configurado, a cada análise, com base em uma suspensão de células S2 (controle) em meio de cultura Sf900 II SFM, sendo esta a fluorescência controle negativo. Assim, somente valores acima desses puderam ser considerados como resultados positivos para células transfectadas expressando a proteína fluorescente. 


\subsubsection{Dosagem de HBsAg}

A dosagem de HBsAg foi feita também pelo método ELISA tendo como base a mesma idéia descrito na seção 3.4.3, porém utilizando o kit de diagnóstico Hetanostika (Biomerieux) conforme instruções do fabricante.

\subsection{MEDIDAS DE CONSUMO E TRANSFERÊNCIA DE OXIGÊNIO}

\subsubsection{Determinação de kLa, OUR e Qo2 pelo Método Dinâmico}

A determinação da OUR, k $\mathrm{L}_{\mathrm{L}}$ e $\mathrm{Q}_{02}$ foi feita utilizando o Método Dinâmico, conforme descrito no item 2.11, ou seja para a medida da OUR, é anotado o valor da leitura de oxigênio dissolvido no tempo $t_{0}$ e é interrompida a transferência de oxigênio zerando a vazão gasosa e a agitação durante um intervalo que pode variar de 2,5 à 6 minutos (dependendo da concentração celular e com intervalos menores para concentrações maiores). Findo este intervalo é anotado o valor de oxigênio dissolvido neste tempo $t_{1}$ e é retomada a agitação e em seguida a vazão gasosa. $A$ OUR é dada pelo coeficiente angular entre o intervalo de tempo $t_{0}$ e $t_{1}$, sendo expressa em mmol de oxigênio por litro por hora.

A velocidade específica de respiração $Q_{O 2}$ foi calculada pela divisão da OUR pela concentração de células viáveis presentes no reator. Este valor foi expresso em mol de oxigênio consumido por célula por segundo.

Neste trabalho, o kıa é fixo e no Ensaio 1, utilizando-se a membrana antiga, tinha-se um $\mathrm{k}_{\mathrm{L}}$ a fixo de $1,40 \mathrm{~h}^{-1}$. A partir do Ensaio 2, quando se trocou a membrana de silicone, foram feitas várias medidas e obteve-se um $k_{\llcorner}$a médio de 1,18 $\pm 0,06 \mathrm{~h}^{-1}$, conforme a Figura 21. Ao longo dos ensaios houve uma deformação na membrana de silicone sendo que o $\mathrm{k}_{\mathrm{L}}$ a médio medido antes do último ensaio chegou a 1,56 \pm $0,17 \mathrm{~h}^{-1}$. 


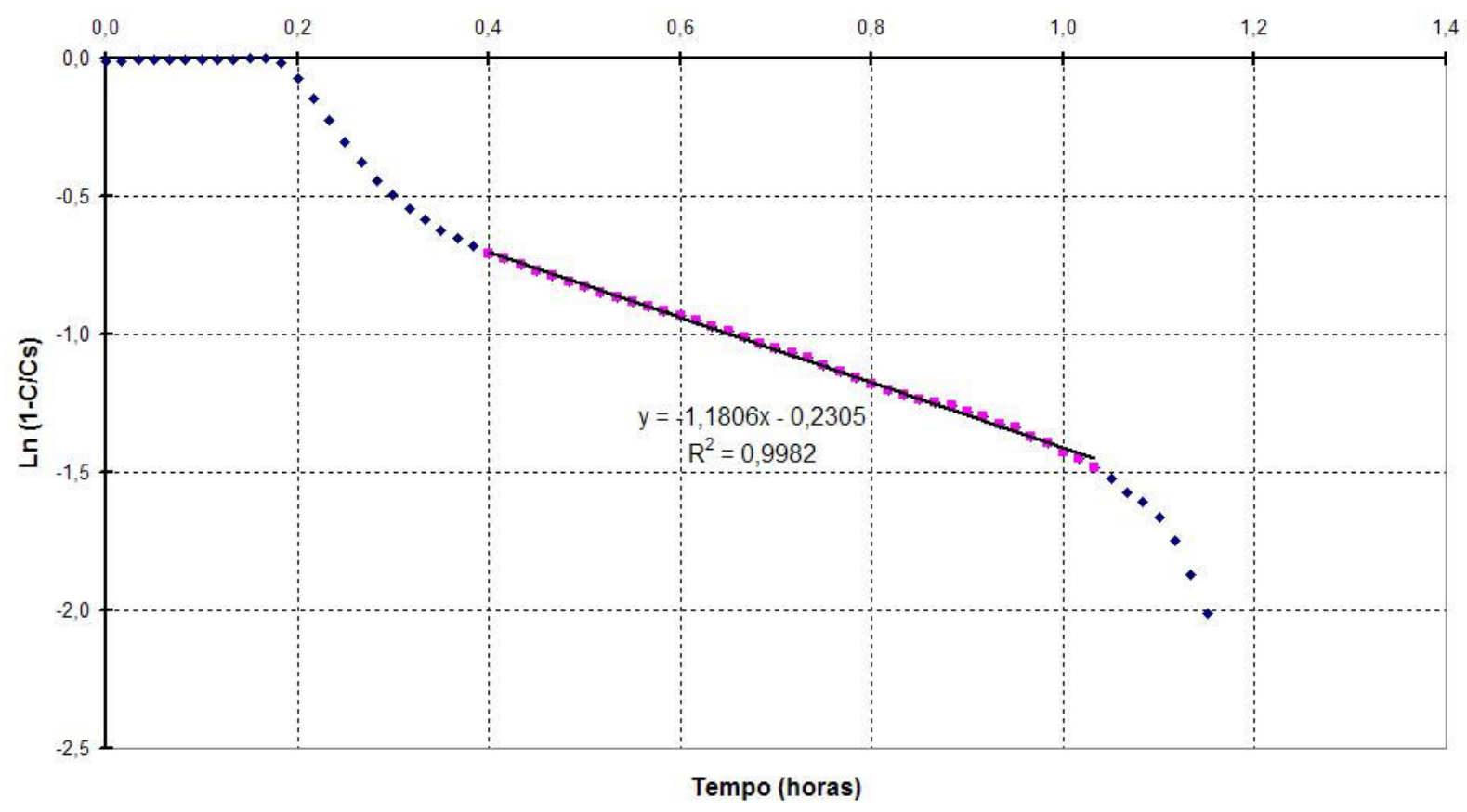

Figura 21 - Cálculo do $k_{L}$ a em meio aquoso.

Este $\mathrm{k}_{\mathrm{L}} \mathrm{a}$ foi medido com o reator apenas com água para que não houvesse a interferência da respiração celular. Ao se transferir oxigênio através do ar que passa pela membrana de silicone, em água inicialmente livre de oxigênio, a camada de líquido subjacente às bolhas (concentração de saturação, $\mathrm{C}_{\mathrm{s}}$ ) será idêntica à concentração de oxigênio no ar e será percebida pelo eletrodo, após a calibração com saturação com ar, como sendo igual a 100. A concentração no seio líquido, C, será inicialmente nula e será percebida pelo eletrodo como sendo igual a 0 . Assim a equação (5) vista na seção 2.11 se torna:

$$
\ln \left(\frac{C_{S}-C}{C_{S}-C_{0}}\right)=-k_{L} a .\left(t-t_{1}\right) \Rightarrow \ln \left(1-\frac{C}{C_{S}}\right)=-k_{L} a . t
$$

No meio com células, durante os ensaios, após a determinação da OUR calculou-se o $\mathrm{k}_{\mathrm{L}} \mathrm{a}$, conforme descrito no item 2.11 sendo expresso $\mathrm{em} \mathrm{h}^{-1}$.

$$
k_{L} a=\frac{O U R}{\left(C_{S}-C_{0}\right)}
$$

Como os resultados obtidos são muito sensíveis e houve mudanças implementadas ao longo dos ensaios, os detalhes exatos de como foi feito cada medida de OUR, estão mais bem descritos em cada um dos Apêndices de D até I. 


\subsubsection{Determinação contínua de OUR por Balanço na Fase Líquida (BFL)}

Dada a característica do sistema de transferência de oxigênio utilizado neste trabalho, que é o $\mathrm{k}_{\mathrm{L}}$ a fixo, foi possível calcular a OUR pelo balanço de oxigênio na fase líquida utilizando a estratégia descrita por Kamen et al. (1996) no cultivo de células de inseto. Foi utilizado, em seu trabalho, um sistema em que foi mantida uma vazão constante e, para a modulação do controle de oxigênio, foi variada a pressão parcial de oxigênio através da mudança na fração mássica de oxigênio no gás de aeração, sendo esta regulação obtida pelo uso de um par de fluxômetros mássicos que dosavam a proporção entre os gases $\mathrm{O}_{2}$ e $\mathrm{N}_{2}$. Assim como no presente trabalho, com $\mathrm{C}$ mantido controlado $(\mathrm{dC} / \mathrm{dt}=0)$ o balanço de oxigênio na fase líquida pode ser dado por:

$$
\text { OUR }=k_{L} a \cdot\left(C_{S}-C\right)
$$

Considerando $\mathrm{k}_{\mathrm{L}} \mathrm{a}$ constante no cultivo e conhecido, C conhecido (medido pelo eletrodo) e $C_{S}$ função da atuação necessária para o controle manter o set-point (Equação 8), a OUR pode ser calculado em tempo real.

\subsubsection{Cálculo de velocidade específica de crescimento}

A velocidade específica de crescimento celular $\left(\mu_{\mathrm{x}}\right)$ e as velocidades específicas de consumo de substrato $\left(\mu_{\mathrm{S}}\right)$ foram calculadas segundo o método geométrico de cálculo de derivadas proposto por Le Duy; Zajic (1973) com as equações deste método implementadas em planilha de cálculo Microsoft Excel por Gombert (2001). No artigo original foi descrito uma sub-rotina em Fortran que posteriormente foi atualizada para a planilha Excel. As curvas das variáveis em função do tempo foram alisadas através do Logiciel du Lissage, software desenvolvido e gentilmente cedido por Dr. Diogo A. Simões, da UFPE (ARDAILLON-SIMÕES; ARROYO; URIBELARREA, 1994). Este programa está baseado em uma variação do Método Spline, que emprega o ajuste de um polinômio de grau n (3 ou4) a um intervalo de dois pontos, incorporando um número de pontos à frente, previamente definido. 


\subsubsection{Anulação completa da transferência de oxigênio}

Durante o Método Dinâmico, em sistemas com transferência de oxigênio por difusão por membrana, no momento em que se interrompe a aeração através do corte da vazão gasosa, dois fatores devem ser considerados. O primeiro é que na cabeça do reator existe ar em equilíbrio com o líquido, portanto quando a concentração de oxigênio no líquido for inferior a concentração de oxigênio na cabeça do reator (devido à respiração celular) haverá transferência superficial, mesmo que a agitação esteja desligada. Portanto, o líquido tenderá a capturar oxigênio do ar na cabeça do reator e existirá assim, uma transferência superficial de oxigênio, mesmo que pequena.

Em segundo lugar, a membrana de silicone está, dentro dela, preenchida com um gás com uma fração de oxigênio muito alta, pois o gás que por ela passa é responsável pela força motriz de transferência. Sendo assim, durante alguns minutos após o desligamento da aeração ainda existirá muito oxigênio no interior da membrana para ser trocada com o meio. Caso se faça passar somente nitrogênio pela membrana, para se extinguir essa transferência, o fenômeno será inverso, ou seja, o líquido fornecerá oxigênio para o interior da membrana.

Para anular esses dois problemas foi proposto, neste trabalho, que as concentrações de oxigênio na cabeça do reator, na membrana e no líquido sejam mantidas iguais durante a execução do método dinâmico. Para tanto se utilizou mais dois fluxômetros e um módulo de controle 0152, conforme mostra a Figura 22.

No momento em que se deseja fazer a medição da OUR modula-se os fluxômetros 1 e 3 para que o gás fornecido $\left(A r+N_{2}\right)$ à membrana pelo fluxômetro 1 e 2 e fornecido à cabeça do reator pelo fluxômetro 3 e 4 apresentem composição equivalente à concentração de oxigênio dissolvido no líquido. Este controle foi feito manualmente, porém facilmente pode ser implementado um programa em LabVIEW (National Instruments, Austin, TX, EUA) que faça este controle.

Conforme a concentração de oxigênio dissolvido no líquido vai decaindo (devido à respiração celular) também se diminui a concentração de oxigênio na cabeça do reator e no interior da membrana. Assim, todos estarão na mesma concentração, 
não existindo nenhum tipo de transferência de oxigênio, pois a força motriz de transferência se anula.

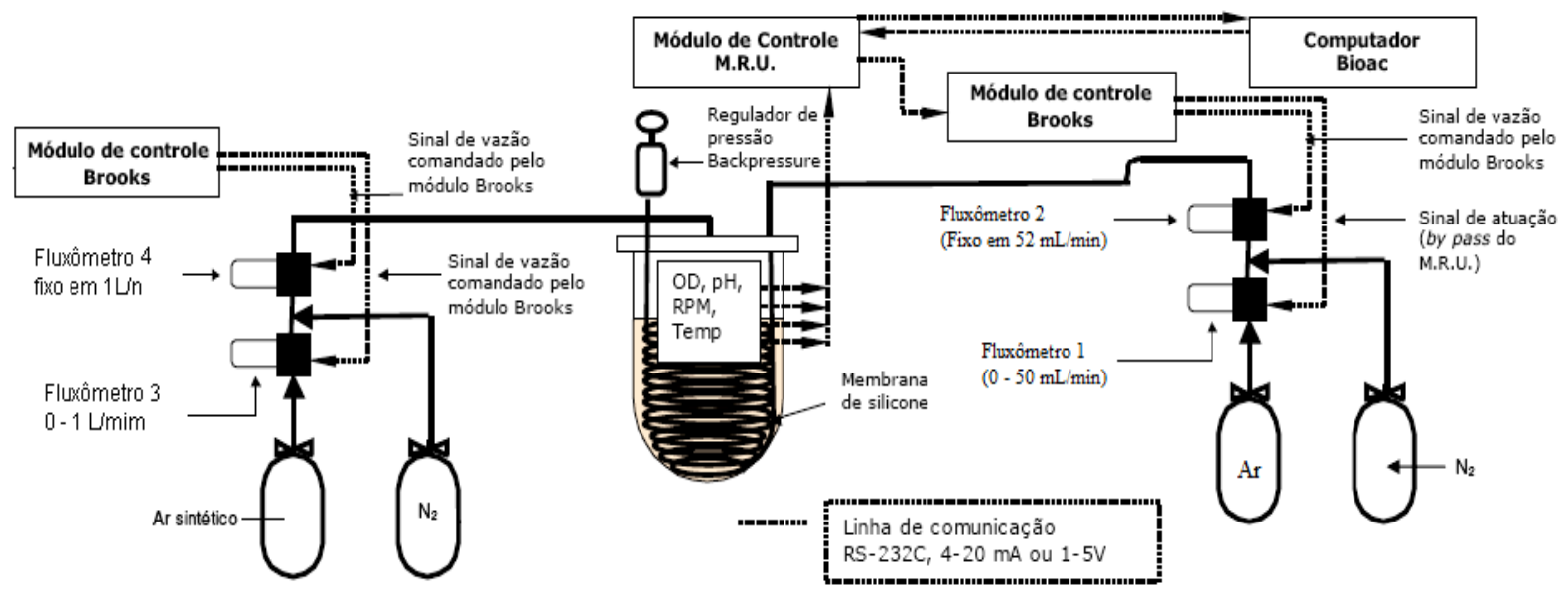

Figura 22 - Esquema da configuração do sistema para medida da OUR no novo Método Dinâmico proposto.

Para validação desta metodologia proposta, foram feitos vários testes durante os ensaios, como manter a agitação ligada ou desligá-la e despressurização da membrana de silicone. Cada método dinâmico executado está apresentado nos Apêndices de $D$ até I e os resultados serão discutidos no próximo capítulo.

\subsubsection{Determinação de $\mathrm{C}_{\text {crit }}$}

Também um novo método para determinação de $\mathrm{C}_{\text {crit }}$ foi implantado durante este trabalho. Ele consiste primeiramente na total anulação da transferência de oxigênio para o meio líquido conforme descrito na seção 3.5 .4 e também mantendo essa interrupção de fornecimento de oxigênio tempo suficiente para que o Qo2 diminua de seu valor máximo. Ou seja, a concentração de oxigênio dissolvido diminui devido à respiração celular até que a velocidade específica de respiração Qo2 seja alterada.

Durante os cultivos em que se mantém a concentração de oxigênio elevada para que este não se torne um fator limitante, o $Q_{02}$ é máximo. Quando C diminui abaixo de $C_{\text {crit, }} Q_{02}$ diminui. Dessa forma, a curva $C=f(t)$ muda sua inclinação, pois a partir deste instante a equação (4) não pode ser integrada para a equação (14) porque Q02 não é constante. 


$$
\begin{gathered}
\frac{d C}{d t}=-Q_{\mathrm{O}_{2}} \cdot X \\
\left(C-C_{0}\right)=Q_{\mathrm{O}_{2}} \cdot X\left(t-t_{0}\right)
\end{gathered}
$$

Nesse ponto, pode-se considerar a concentração como $\mathrm{C}_{\text {crit, }}$ conforme a Figura 23.

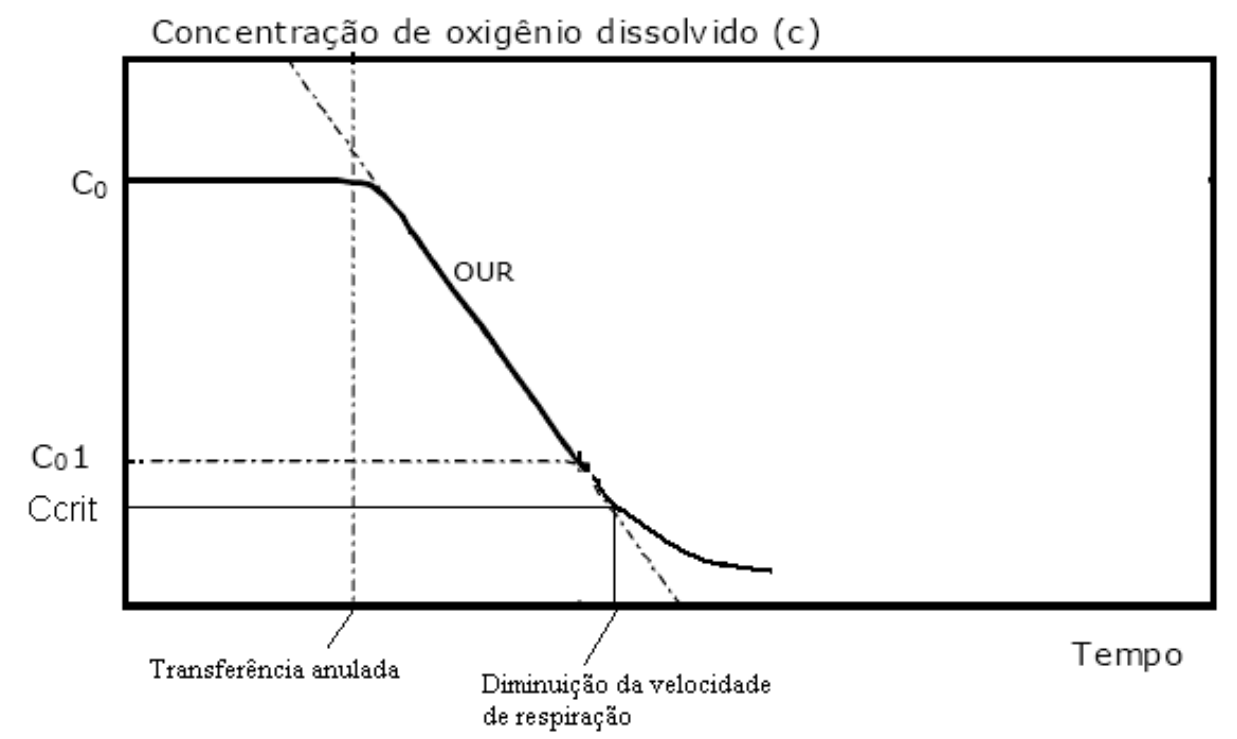

Figura 23 - Representação esquemática do efeito da diminuição de oxigênio dissolvido na velocidade de respiração

Portanto, com a aplicação deste método, é possível verificar a faixa em que se encontra o $\mathrm{C}_{\text {crit. }}$

Há também a possibilidade de se estar, com este método, alterando a população (matando-a ou selecionando-a), porém como o objetivo deste trabalho é o estudo da atividade respiratória, correu-se este risco. Mas, em comparação com os dados obtidos pelos outros colegas do projeto temático em relação ao crescimento e produção, não foi verificado nenhum tipo de diferença substancial. Talvez isso indique não haver um problema real de alteração na população, mesmo porque essa oscilação do oxigênio dissolvido é rápida, retornando ao patamar de controle após a verificação do $\mathrm{C}_{\text {crit. }}$ 


\section{RESULTADOS E DISCUSSÃO}

Nesta seção serão apresentados e discutidos os ensaios significativos para o estudo da atividade respiratória de células de insetos. Entre os ensaios realizados não serão apresentados os realizados para o entendimento do equipamento, do protocolo e de novas técnicas desenvolvidas e ainda os ensaios que não obtiveram um desenvolvimento satisfatório devido a problemas de não crescimento ou contaminação. Desta maneira, tem-se uma apresentação e uma discussão mais específica, evitando-se a apresentação de dados sem total consistência para a discussão.

Na Tabela 1 são apresentados os ensaios válidos em meio de cultura SF900 II (Gibco, Grand Island, NY) sem soro fetal bovino, controlados a $40 \%$ de oxigênio dissolvido, com transferência por difusão de membrana de silicone:

Tabela 1 - Quadro de Ensaios

\begin{tabular}{lc}
\hline \multicolumn{1}{c}{ Ensaio } & Célula \\
\hline Ensaio 1 (Sf9) & Sf9 \\
Ensaio 2 (S2a) & S2 selvagem p.57 \\
Ensaio 3 (S2b) & S2 selvagem p.65 \\
Ensaio 4 (GPV) & S2AcGPV2 \\
Ensaio 5 (EGFP) & S2MtEGFP \\
Ensaio 6 (HBsAg) & S2AcHBsAgHy \\
\hline
\end{tabular}

\subsection{ENSAIO 1 (Sf9)}

Este ensaio foi realizado com célula Spodoptera frugiperda (Sf9) na passagem 98 sem infecção viral.

O oxigênio dissolvido (OD) foi controlado a $40 \%$ e a sobrepressão na membrana de silicone foi mantida a 0,4 bar até o $7^{\circ}$ dia e aumentada para 1 bar a partir de então 
(Apêndice A). Esse aumento foi necessário, pois o fornecimento de oxigênio estava chegando ao limite (limitado pela ação do fluxômetro) podendo tornar-se um fator limitante. A agitação foi mantida a $100 \mathrm{rpm}$ e a temperatura controlada a $28^{\circ} \mathrm{C}$.

Em todos os gráficos apresentados neste trabalho, a tomada de tempo foi de minuto em minuto e em alguns gráficos suprimiu-se a visualização desses pontos para evitar uma poluição visual. A repetição dos dados, como crescimento celular, em vários gráficos foi feito para ter-se maior clareza. A grande maioria dos gráficos de mesmo tipo está na mesma escala, para que facilitasse a comparação entre os ensaios. Porém, alguns gráficos foram feitos na melhor escala para cada ensaio para que os dados ali mostrados pudessem ser melhor apresentados.

No Gráfico 1, observam-se as principais variáveis deste ensaio. A agitação, temperatura e oxigênio dissolvido foram bem controlados. Apenas no início do ensaio houve um pequeno problema com o manômetro do cilindro de oxigênio.

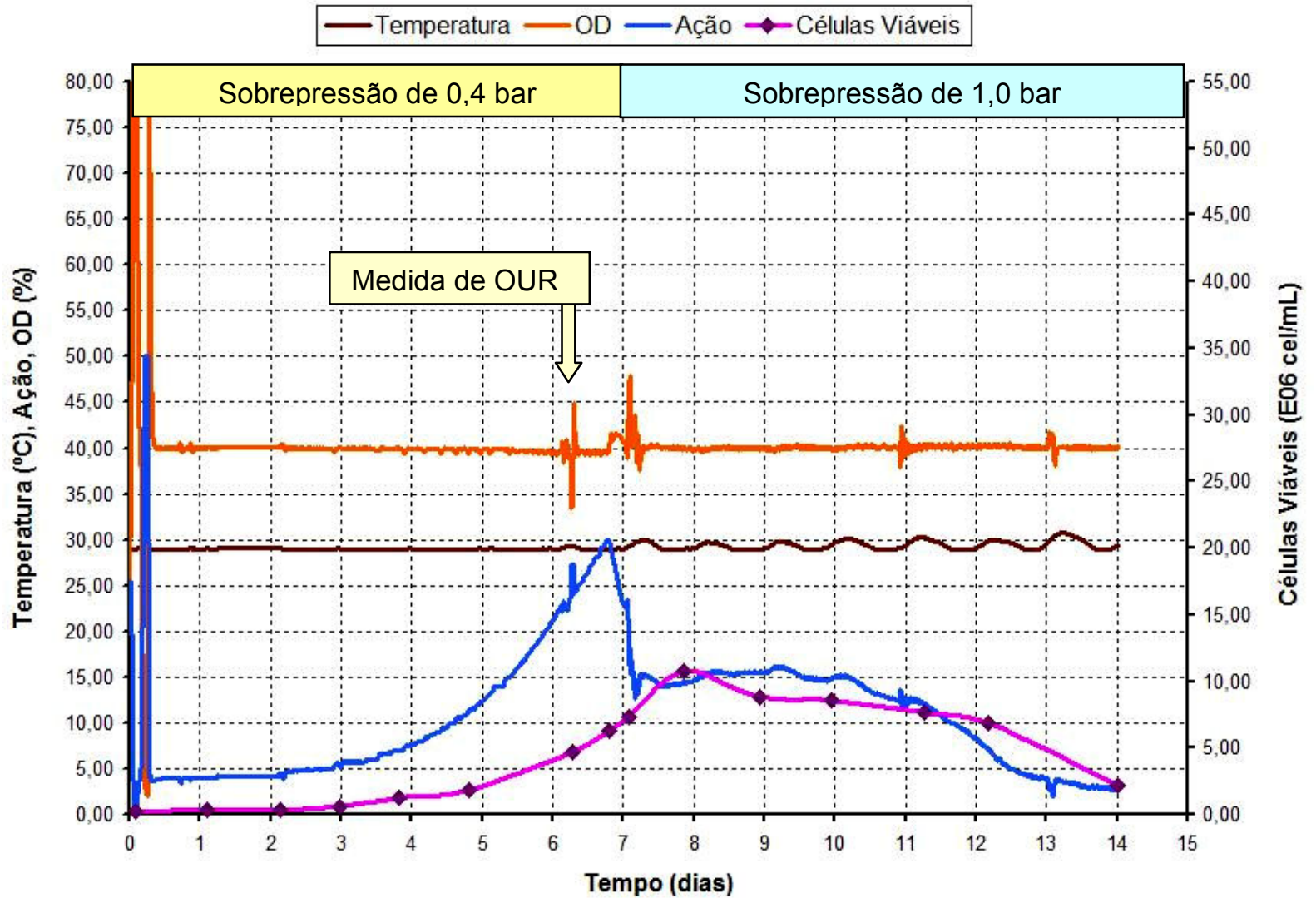

Gráfico 1 - Temperatura, OD, ação do controlador de OD e concentração de células viáveis do Ensaio 1 (Sf9) em função do tempo.

Como foi visto na seção 3.2.1, o fluxômetro de oxigênio é de $50 \mathrm{~mL} / \mathrm{min}$ e como cada unidade da ação corresponde a 1,25 mL/min de vazão de gás, logo a ação máxima 
possível para esse fluxômetro é de $40 \%$. Pode-se observar, no Gráfico 1, que a atuação da ação por volta do $7^{\circ}$ dia estava chegando próxima ao seu limite, que é de $40 \%$. Assim, para evitar problemas de limitação pelo oxigênio, a sobrepressão foi aumentada para 1 bar e após pequena oscilação o OD voltou a ser bem controlado.

A OUR foi medida pelo Método Dinâmico, conforme seção 2.11, na concentração celular de $4,70.10^{6} \mathrm{cel} / \mathrm{mL}$, no instante 6,3 dias, obtendo-se uma OUR de 1,26 mmol $\mathrm{O}_{2} /(\mathrm{L} . \mathrm{h})$, um $\mathrm{k}_{\mathrm{L}}$ a de $1,44 \mathrm{~h}^{-1}$ e o $\mathrm{Q}_{\mathrm{O} 2}$ nestas condições foi de $74,7.10^{-18} \mathrm{~mol}$ $\mathrm{O}_{2} /$ (cel.s), conforme descrito no Apêndice D.

No Gráfico 2, observa-se a medida da OUR e $Q_{\mathrm{O} 2}$ estimada através do Balanço na Fase Líquida (BFL) conforme descrita na seção 3.5.2. Pode-se observar que os valores encontrados para a OUR e $Q_{02}$ através do Método Dinâmico Tradicional estão próximos aos verificados pelo Balanço na Fase Líquida.

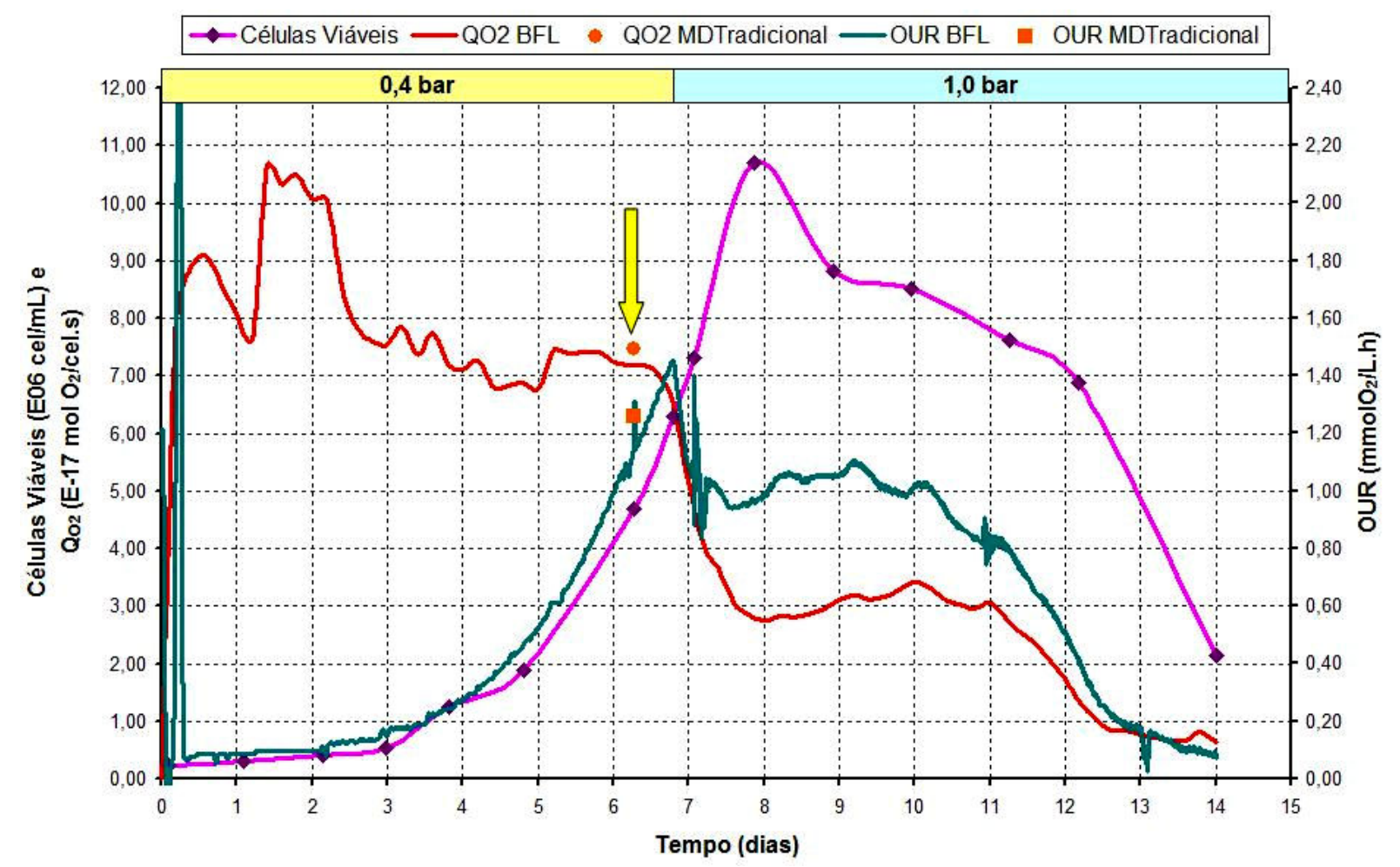

Gráfico 2 - Medidas de OUR e Q Ensaio 1 (Sf9) em função do tempo.

No Gráfico 3, tem-se o crescimento celular. A partir de um inóculo de 0,22.10 $\mathrm{cel} / \mathrm{mL}$, as células cresceram exponencialmente até uma concentração celular máxima de $10,70.10^{6} \mathrm{cel} / \mathrm{mL}$ aproximadamente no $8^{\circ}$ dia. A viabilidade esteve por volta de $97 \%$ até o $8^{\circ}$ dia decaindo daí em diante. A máxima velocidade específica de crescimento celular $\left(\mu_{\text {máx }}\right)$ foi de 0,70 dia $^{-1}\left(0,029 \mathrm{~h}^{-1}\right)$ verificada até o $6^{\circ}$ dia. 
No Gráfico 4, observa-se o crescimento celular por spline e seu logaritmo neperiano (In) e também a velocidade específica de crescimento celular.

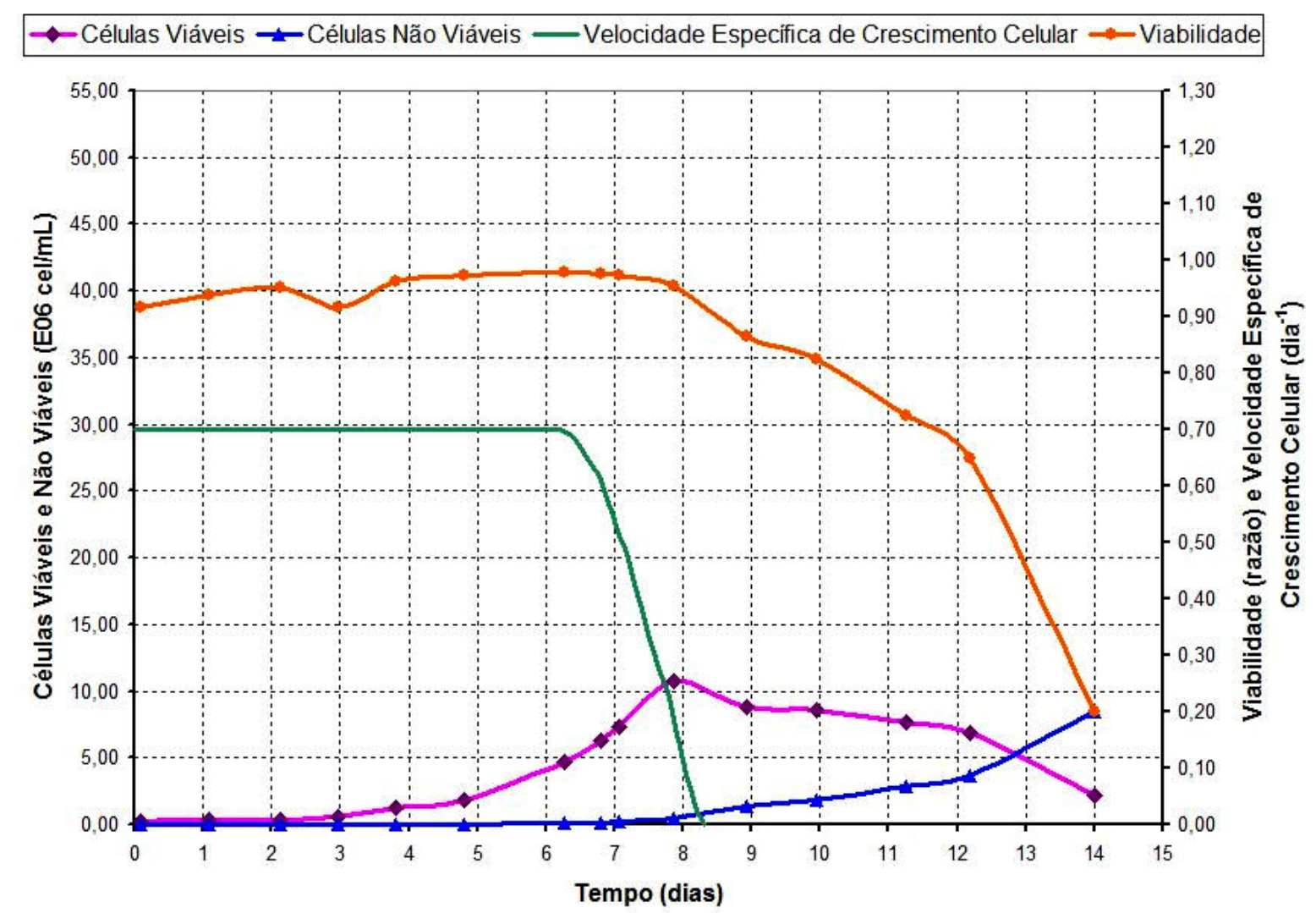

Gráfico 3 - Viabilidade celular e velocidade específica de crescimento celular do Ensaio 1 (Sf9) em função do tempo

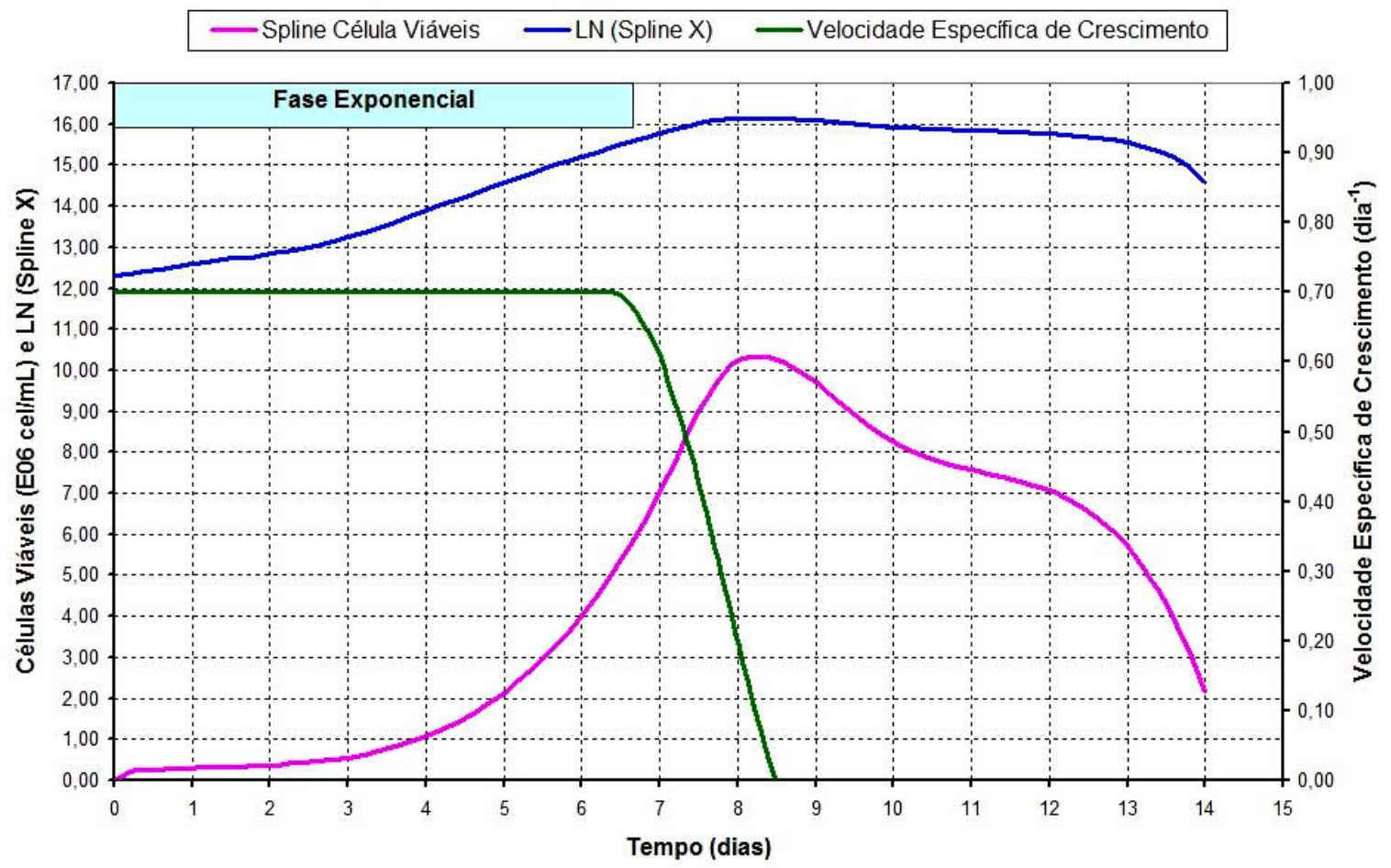

Gráfico 4 - Velocidade específica de crescimento celular do Ensaio 1 (Sf9) em função do tempo. 
No Gráfico 5, pode ser observado o perfil das concentrações de glicose, lactato e glutamina ao longo do tempo. A glicose foi consumida chegando ao final do ensaio em $0,13 \mathrm{~g} / \mathrm{L}$ e passou a ser consumida mais rapidamente após a fase exponencial. Como ao final da fase exponencial ainda existia cerca de $6,5 \mathrm{~g}$ de glicose por litro, é pouco provável que a saída da fase exponencial de crescimento tenha sido causada pela falta de glicose, mas sim pela falta de outro nutriente não pesquisado neste trabalho. A glutamina também foi consumida ao longo do tempo chegando ao final do ensaio em $1,89 \mathrm{~g} / \mathrm{L}$. O lactato foi produzido, chegando a uma concentração de $1,15 \mathrm{~g} / \mathrm{L}$.

O perfil de pH também é apresentado no Gráfico 5 e seu valor inicial foi de 6,2. Durante o ensaio sofreu pequenas alterações e somente no final do cultivo é que houve uma queda mais acentuada.

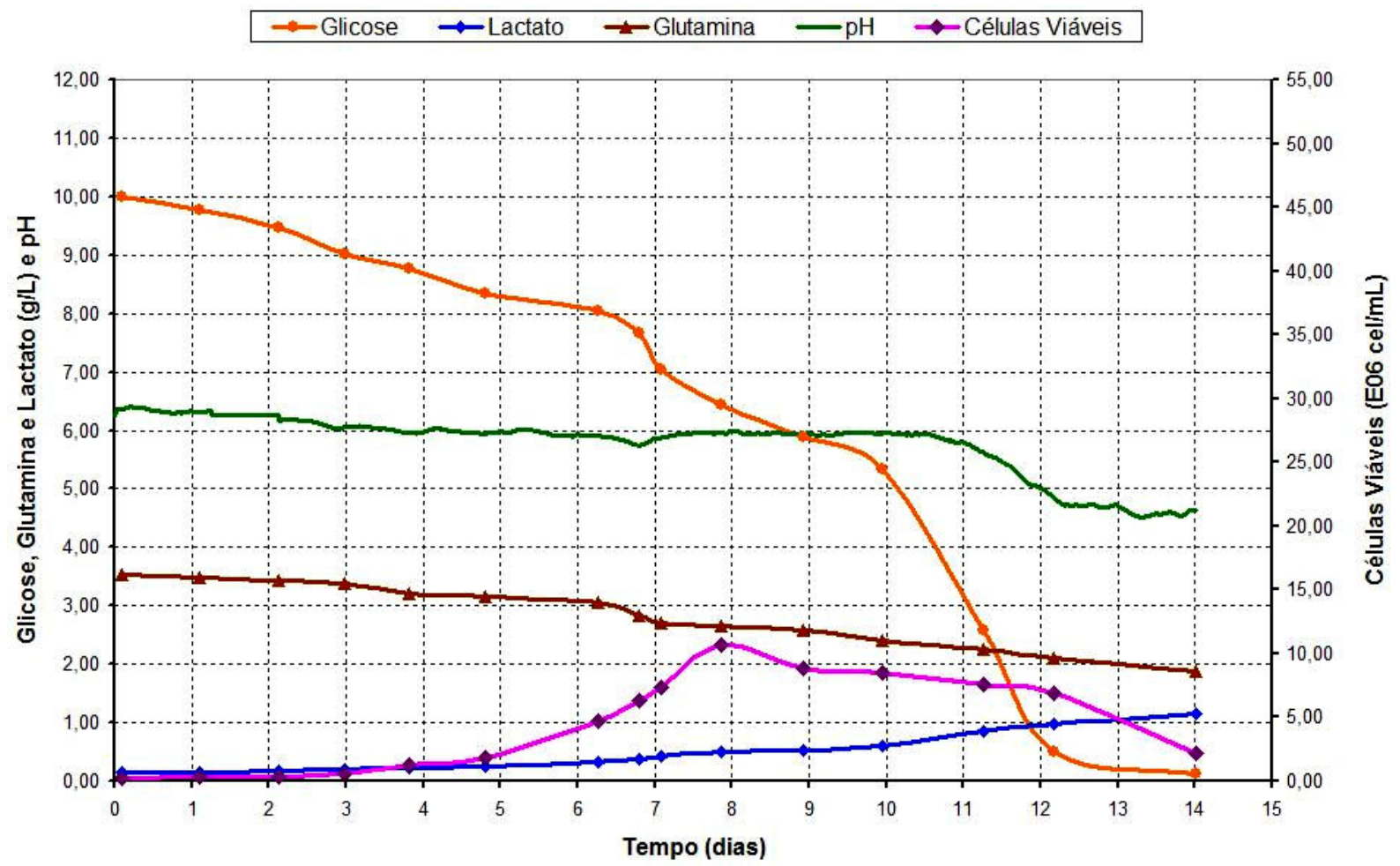

Gráfico 5 - pH e concentração de glicose, glutamina e lactato do Ensaio 1 (Sf9) em função do tempo

A trealose, que é um dímero de glicose e é o açúcar mais abundante na hemolinfa de insetos, chegando a concentrações maiores que $30 \mathrm{~g} / \mathrm{L}$ (THOMPSON; BORCHARDT; WANG, 2003), não foi pesquisada neste experimento. Porém, em um estudo feito a parte (resultados não apresentados), chegou-se a conclusão que a adição de $1 \mathrm{~g} / \mathrm{L}$ de trealose ao fim da fase exponencial de um cultivo de Sf9 em 
Sf900 II, interfere na produção de lactato diminuindo sua produção em cerca de $30 \%$.

As velocidades específicas de consumo de glicose e glutamina tiveram seu valor máximo no início do cultivo, conforme observado no Gráfico 6. A velocidade específica de consumo de glicose $\left(\mu_{\mathrm{S}}\right)$ máxima foi de $9,9.10^{-10} \mathrm{~g} /($ cel.dia). Segundo Ferrance; Goel e Ataai (1993) e Mendonça; Palomares e Ramírez (1999), a glutamina apresenta velocidades de consumo superiores aos dos demais aminoácidos nas células Sf9.

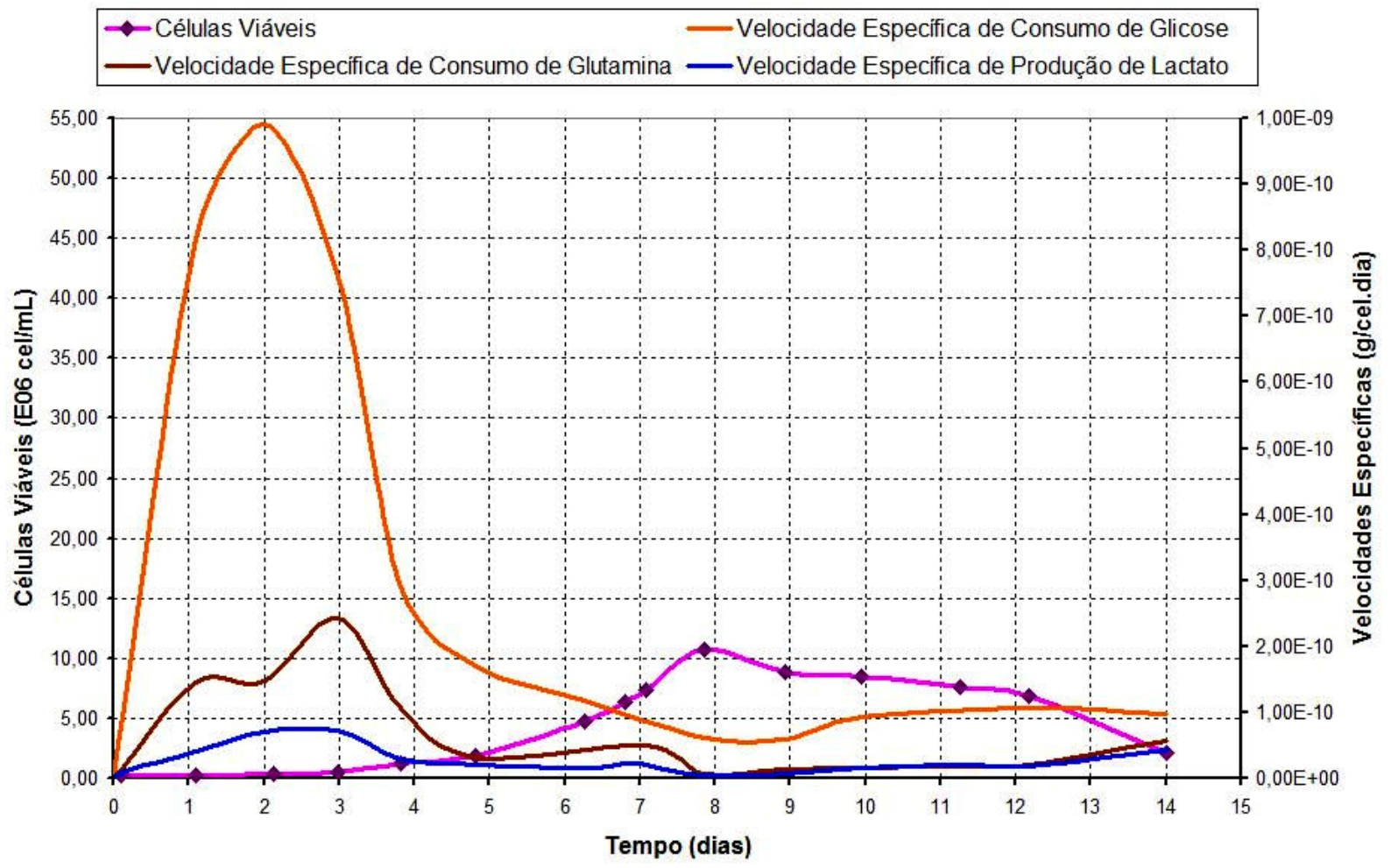

Gráfico 6 - Velocidades específicas de consumo de glicose e glutamina e produção de lactato do Ensaio 1 (Sf9) em função do tempo

\subsection{ENSAIO 2 (S2a)}

Este ensaio foi realizado com células $\mathrm{S} 2$ selvagem na passagem 57 em meio de cultura SF900 II isento de soro fetal bovino e foi controlado a $40 \%$ de OD com sobrepressão na membrana de silicone de 0,5 bar durante todo o ensaio. Neste ensaio não houve condições do uso de refrigeração do cultivo, assim a temperatura sofreu algumas oscilações, chegando a $35^{\circ} \mathrm{C}$, como observado no Gráfico 7 . Neste 
gráfico, as grandes variações de OD são devido às medidas de OUR através do Método Dinâmico como visto na seção 2.11.

A concentração celular inicial foi de $0,24.10^{6} \mathrm{cel} / \mathrm{mL}$, chegando a $44,80.10^{6} \mathrm{cel} / \mathrm{mL}$ no $8^{\circ}$ dia. A fase exponencial, muito curta, verificada no início do cultivo foi interrompida a partir do primeiro grande aumento da temperatura. A curva de crescimento a partir do dia 2, quando sofreu essa interrupção, torna-se praticamente uma reta. Esse efeito pode ter sido causado pela alta temperatura como pode ser notado devido ao aumento da ação. Depois que a temperatura retoma os $28^{\circ} \mathrm{C}$, a ação volta a ter o comportamento esperado, aumentando conforme cresce a população e decrescendo com a queda da viabilidade celular.

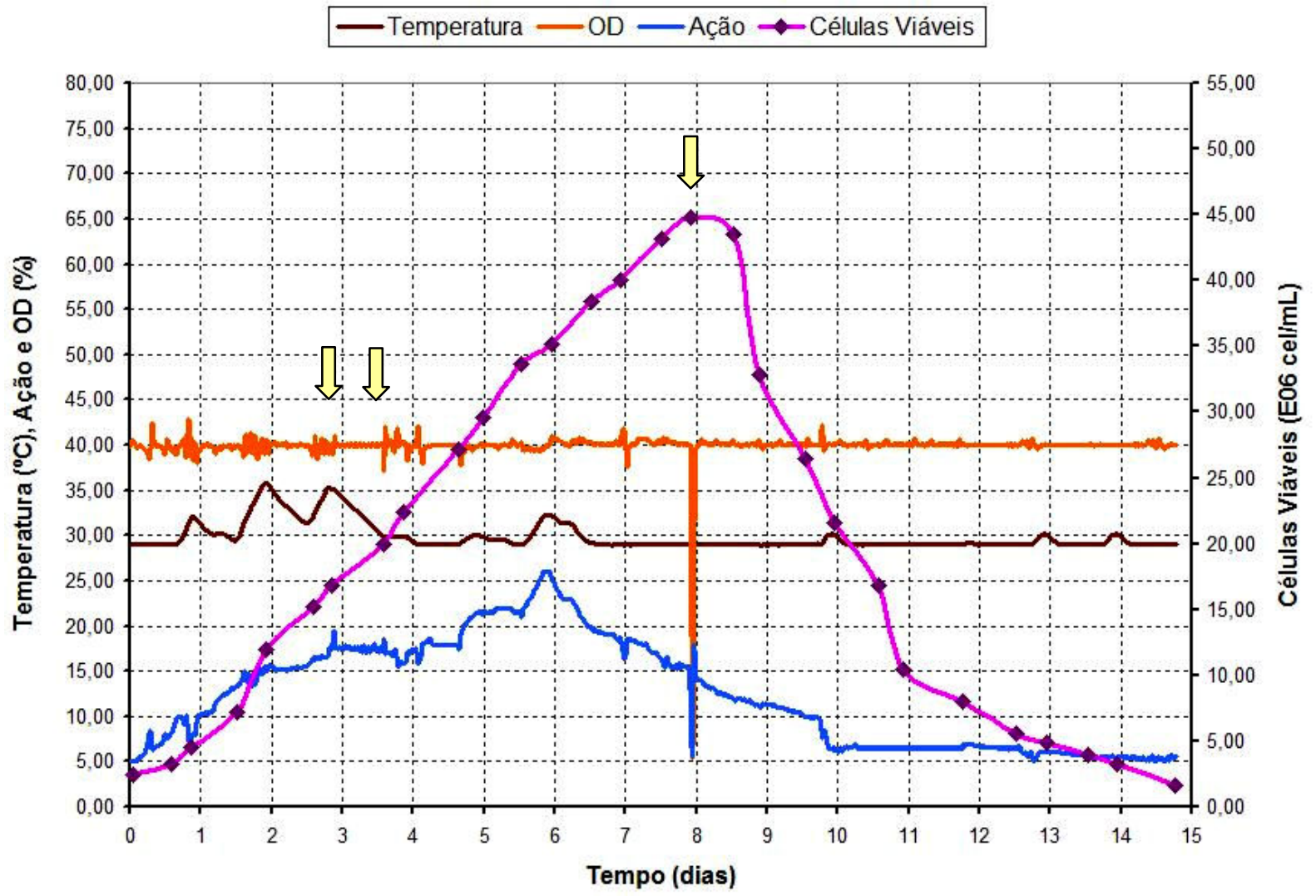

Gráfico 7 - Temperatura, OD, ação do controlador de OD e concentração de células viáveis do Ensaio 2 (S2a) em função o tempo. As setas representam as tomadas de medidas através do Método Dinâmico.

Durante a execução do $3^{\circ}$ Método Dinâmico, desligou-se a ação, para que esta não acumulasse um efeito devido à queda do $\mathrm{OD}$, e, quando fosse retomada a aeração, ela não aplicasse um aumento muito grande da ação. Como se deixou um tempo grande (6 minutos na concentração celular máxima) sem aeração, observou-se uma reta maior para cálculo da OUR. Quando se religou todos os controles e observando 
a retomada da aeração, se pensou na teoria que diz que $\mathrm{C}_{\text {crit }}$ é a concentração de oxigênio dissolvido no líquido quando o $Q_{02}$ torna-se máximo e a partir daí constante. Portanto, pensando inversamente, ou seja, interrompendo-se a aeração, a concentração de oxigênio dissolvido no líquido decresce, com as células respirando em $Q_{02}$ máximo, porém, abaixo de $C_{\text {crit }} \circ Q_{02}$ muda constantemente, mudando, portanto a inclinação da curva. Foi a partir daí que, nos próximos ensaios, implantou-se e aprimorou-se um método para a medição de $\mathrm{C}_{\text {crit }}$ em qualquer instante do ensaio.

OUR, $\mathrm{k}_{\mathrm{L}}$ a e $\mathrm{Q}_{\mathrm{O} 2}$ foram medidos em três instantes do ensaio (Apêndice $\mathrm{E}$ ) conforme o Método Dinâmico descrito na seção 2.11 e apresentados na Tabela 2. No Gráfico 7, as setas indicam os momentos de medida.

Tabela 2 - Medidas de OUR, $\mathrm{k}_{\mathrm{L}}$ a e $\mathrm{Q}_{\mathrm{O} 2}$ do Ensaio 2 (S2a)

\begin{tabular}{ccccc}
\hline $\mathbf{T}$ (dias) & $\mathbf{X}(\mathrm{cel} / \mathrm{mL})$ & OUR $\left(\mathbf{m m o l O}_{2} \cdot \mathrm{L}^{-1} \cdot \mathbf{h}^{-1}\right)$ & $\mathbf{k}_{\mathrm{L}} \mathbf{a}\left(\mathbf{h}^{-1}\right)$ & $\mathbf{Q}_{\mathrm{O} 2}\left(\mathrm{molO}_{2} \cdot \mathbf{c e l}^{-1} \cdot \mathbf{s}^{-1}\right)$ \\
\hline 2,85 & $16,8 \cdot 10^{6}$ & 0,39 & 0,66 & $6,45 \cdot 10^{-18}$ \\
3,58 & $20,0 \cdot 10^{6}$ & 0,40 & 0,67 & $5,53 \cdot 10^{-18}$ \\
7,91 & $44,8 \cdot 10^{6}$ & 0,85 & 1,64 & $5,26 \cdot 10^{-18}$ \\
\hline
\end{tabular}

Portanto, observa-se que o maior $Q_{\mathrm{O} 2}$ foi verificado no início do ensaio, justamente quando houve um grande aumento da temperatura. Nos instantes de aumento de temperatura houve também um aumento da ação.

No Gráfico 8, observa-se as medidas da OUR e Qo2 estimada através do Balanço na Fase Líquida (BFL) conforme descrita na seção 3.5.2. Pode-se observar que os valores encontrados para a OUR e Qo2 através do Método Dinâmico Tradicional não estão muito próximos aos verificados pelo Balanço na Fase Líquida, indicando que os valores encontrados através do Método Dinâmico Tradicional estão super dimensionados. Deve-se lembrar que no BFL o $\mathrm{k}_{\mathrm{L}}$ a é considerado fixo para este sistema e como sendo inicialmente de: $1,18 \pm 0,06 \mathrm{~h}^{-1}$, como mostrado na seção 3.5.1. 


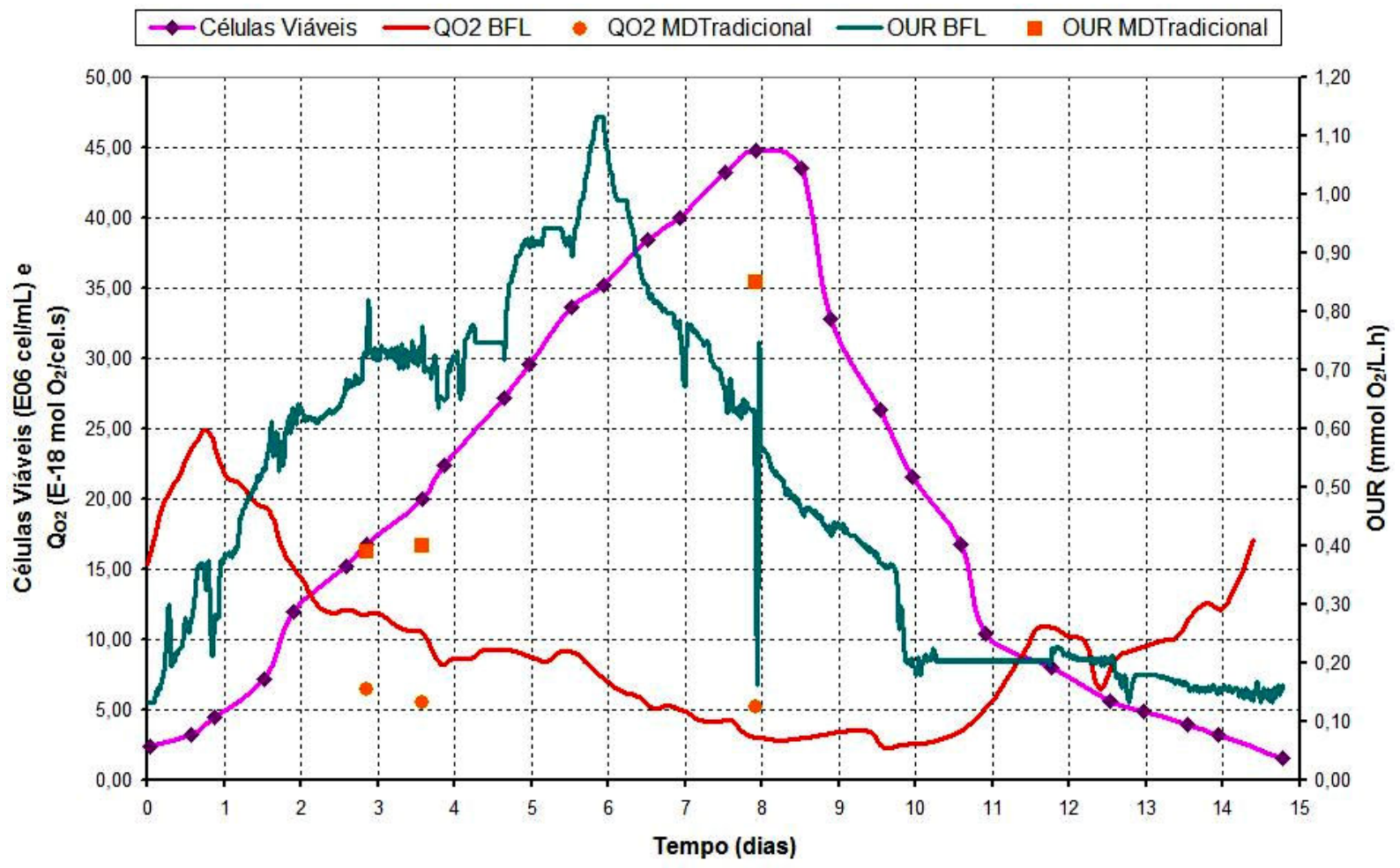

Gráfico 8 - Medidas de OUR e Q Ensaio 2 (S2a) em função do tempo.

No Gráfico 9, observa-se que a máxima velocidade específica de crescimento celular $\left(\mu_{\max }\right)$ foi de $1,03 \mathrm{dia}^{-1}\left(0,043 \mathrm{~h}^{-1}\right)$ verificado no início do cultivo. Nota-se também, que a velocidade específica de crescimento celular foi afetada com os aumentos da temperatura, pois até o segundo dia a velocidade específica de crescimento celular foi de 1,03 $\mathrm{dia}^{-1}$, mas depois dos grandes aumentos de temperatura a velocidade específica de crescimento celular caiu para 0,34 dia ${ }^{-1}$. Pode-se perceber que a curva do crescimento celular começava a fazer uma fase exponencial até o $2^{\circ}$ dia, quando o efeito da temperatura fez mudar o crescimento celular.

No Gráfico 10, observa-se o crescimento celular por spline e seu logaritmo neperiano (In) e também a velocidade específica de crescimento celular. Observamse as duas fases exponenciais provocadas pelo efeito da alta temperatura. 


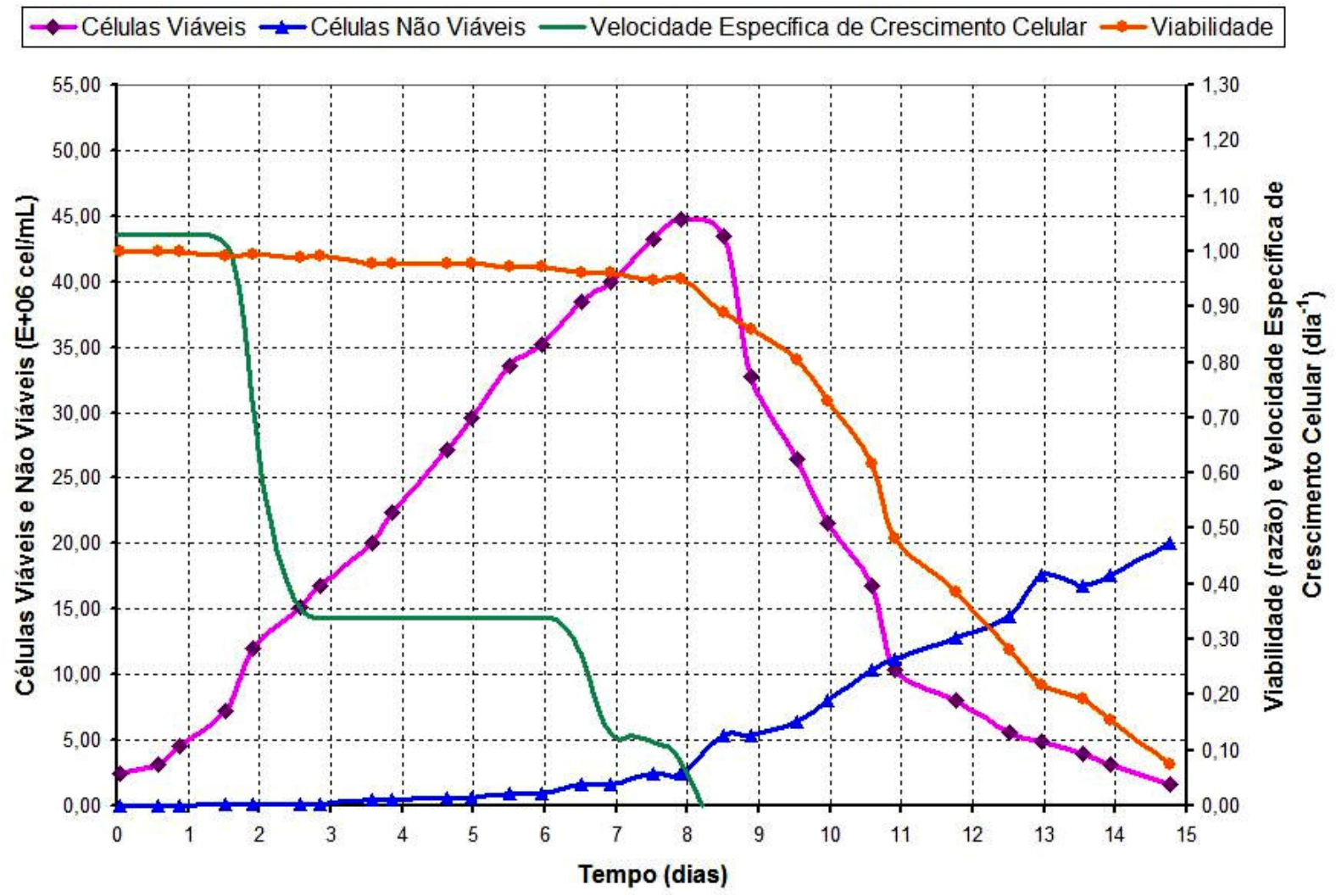

Gráfico 9 - Viabilidade celular e velocidade específica de crescimento celular do Ensaio 2 (S2a) em função do tempo

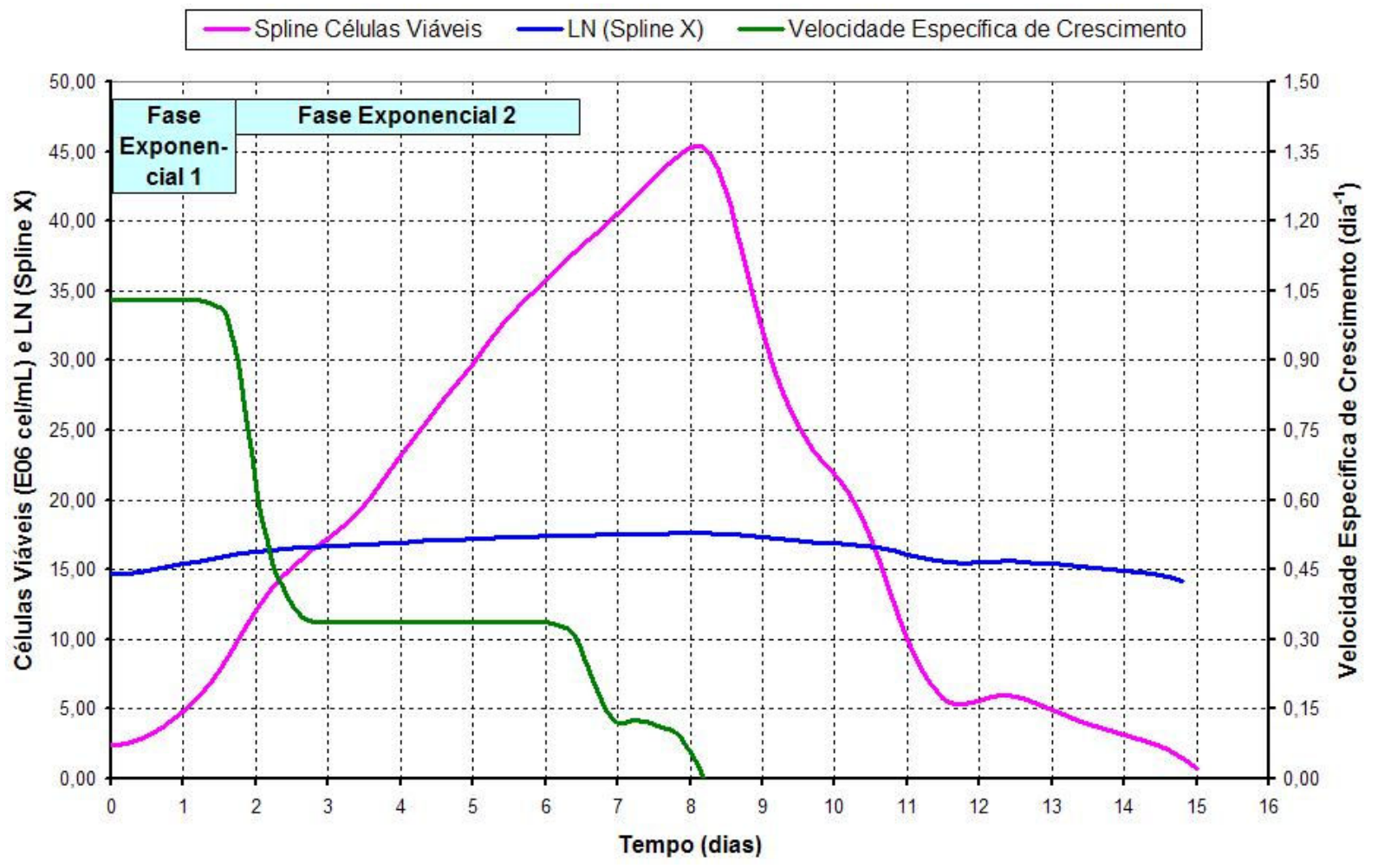

Gráfico 10 - Velocidade específica de crescimento celular do Ensaio 2 (S2a) em função do tempo. 
No Gráfico 11, tem-se o perfil de glicose, lactato e glutamina ao longo do cultivo. A glicose foi consumida chegando a $0,78 \mathrm{~g} / \mathrm{L}$ e a glutamina a $1,13 \mathrm{~g} / \mathrm{L}$ ao fim do ensaio. Lactato foi produzido chegando a 1,69 $\mathrm{g} / \mathrm{L}$.

$\mathrm{O}$ pH iniciou-se em 6,05 e ao término de 14 dias de cultivo era de 8,05.

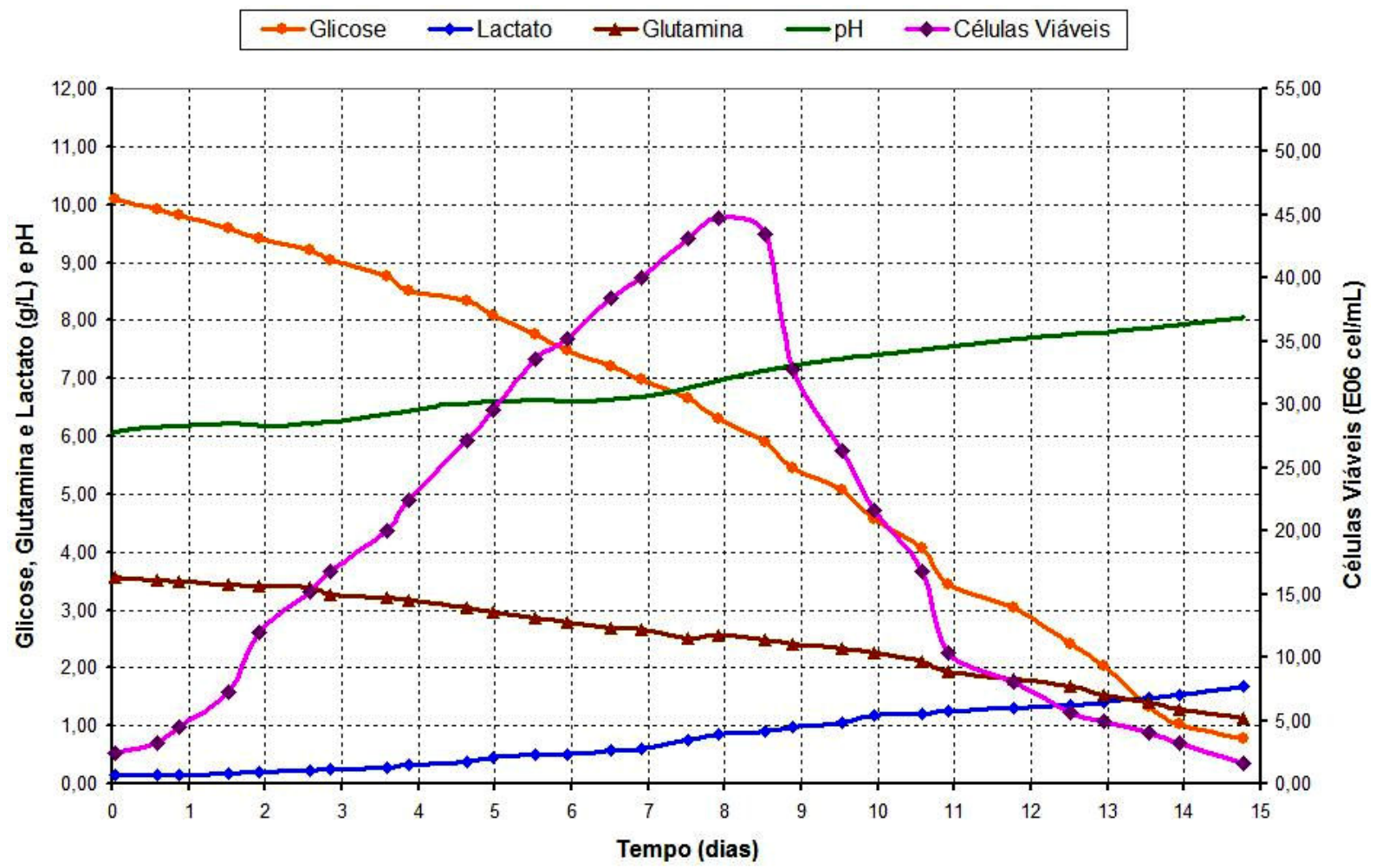

Gráfico 11 - pH e concentração de glicose, glutamina e lactato do Ensaio 2 (S2a) em função do tempo

No Gráfico 12, têm-se os perfis das velocidades específicas de consumo de glicose e glutamina e da velocidade específica de produção de lactato. A velocidade específica máxima de consumo de glicose foi de $8,13.10^{-11} \mathrm{~g} /$ (cel.dia) verificada no $1^{\circ}$ dia de cultivo, após o problema com a temperatura a velocidade de consumo de glicose caiu para $3,4 \cdot 10^{-11} \mathrm{~g} /($ cel.dia). 


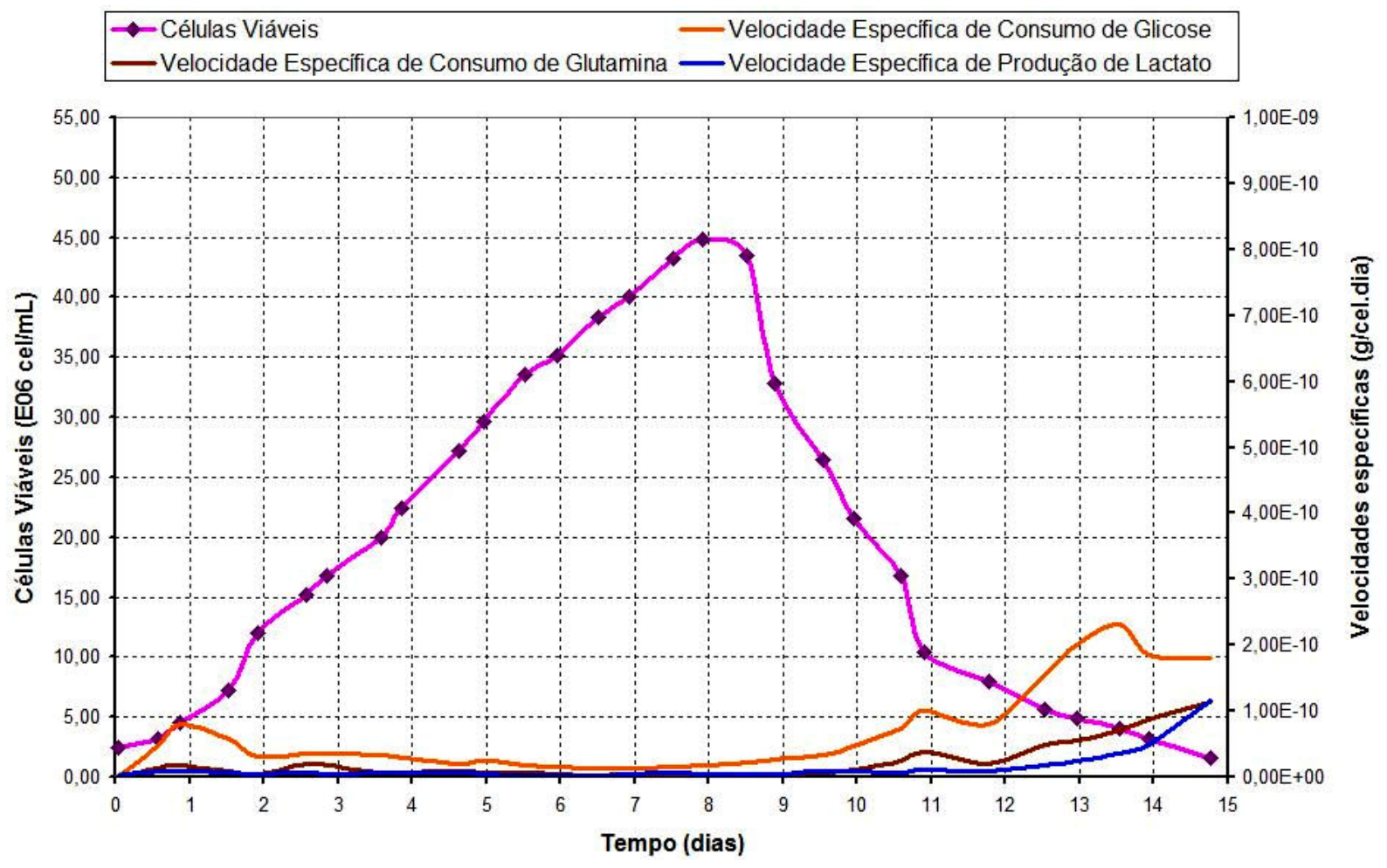

Gráfico 12 - Velocidades Específicas de Consumo e Produção de Substratos do Ensaio 2 (S2a) em função do tempo

Após a queda da viabilidade, a velocidade específica de consumo dos substratos aumentou bastante. $\mathrm{Na}$ fase de crescimento celular, as máximas velocidades específicas de consumo de glicose e glutamina foram atingidas no início do cultivo, decaindo depois disso. O valor, dessas velocidades específicas, mostrou-se muito baixo. Já o lactato começou a ser produzido quando a quantidade de glicose presente na cultura chegou a níveis inferiores a $3 \mathrm{~g} / \mathrm{L}$.

Como parece que a temperatura foi um fator de muita influência no cultivo, foi feito mais um ensaio com célula S2 selvagem, agora com um perfeito controle da temperatura, para que se pudesse ter um parâmetro de comparação e de discussão e, ainda, terem-se os valores corretos da atividade respiratória das células S2 selvagem e do desenvolvimento do ensaio.

\subsection{ENSAIO $3(\mathrm{~S} 2 \mathrm{~b})$}

Este ensaio foi realizado com células S2 selvagem na passagem 65 em meio de cultura SF900 II sem soro fetal bovino e controlado a $40 \%$ de OD com sobrepressão 
na membrana de silicone de 0,5 bar durante todo o ensaio. Este ensaio transcorreu muito bem, com os controles apresentando um desempenho satisfatório. Quanto ao número da passagem, não existem diferenças na fisiologia das células entre os ensaios E2 e E3, pois são passagens muito próximas. Porém, sempre que possível, deve-se saber qual a passagem em que as células se encontram, pois podem existir modificações após muitas passagens e também, sabendo-se a passagem, servirá de modelo para comparação para outros pesquisadores. Este ensaio com célula S2 selvagem foi repetido, pois o anterior (E2) teve problemas com a temperatura elevada. Assim, com um ensaio com correto controle, pôde-se ver também a influência da temperatura no crescimento das células e no desenvolvimento do ensaio.

No Gráfico 13 podem ser observados todos os controles. Nota-se, mais uma vez, que os picos descendentes em OD e ação são devidos ao Método Dinâmico, além de que, a partir deste ensaio, foi implementada a nova maneira desenvolvida para cálculo do $\mathrm{C}_{\text {crit, }}$ conforme seção 3.5.5, o que aumentou ainda mais os picos. Pode-se observar ainda, que a ação máxima solicitada foi por volta de $24 \%$, o que mostra que o fornecimento máximo de oxigênio não ultrapassou $30 \mathrm{~mL} / \mathrm{min}$. Outras pequenas alterações no OD foram devido a pequenos problemas técnicos, como troca de cilindro de gás e falta de energia.

A concentração celular inicial foi de $0,98.10^{6} \mathrm{cel} / \mathrm{mL}$, chegando a $51,20.10^{6} \mathrm{cel} / \mathrm{mL}$ no $4^{\circ}$ dia de cultivo. Comparando-se com o Ensaio 2, este ensaio foi feito em um tempo mais curto devido a concentração inicial do inóculo ser maior e também ao fato de ter existido uma fase exponencial e não um crescimento linear como no E2.

OUR, $k_{\mathrm{L}}$ a e $\mathrm{Q}_{\mathrm{O} 2}$ foram medidos em três instantes do ensaio (Apêndice $\mathrm{F}$ ) conforme o Método Dinâmico descrito na seção 2.11 e apresentados na Tabela 3. No Gráfico 13 , as setas indicam os momentos de medida. O maior $Q_{02}$ foi alcançado na fase exponencial do cultivo. 


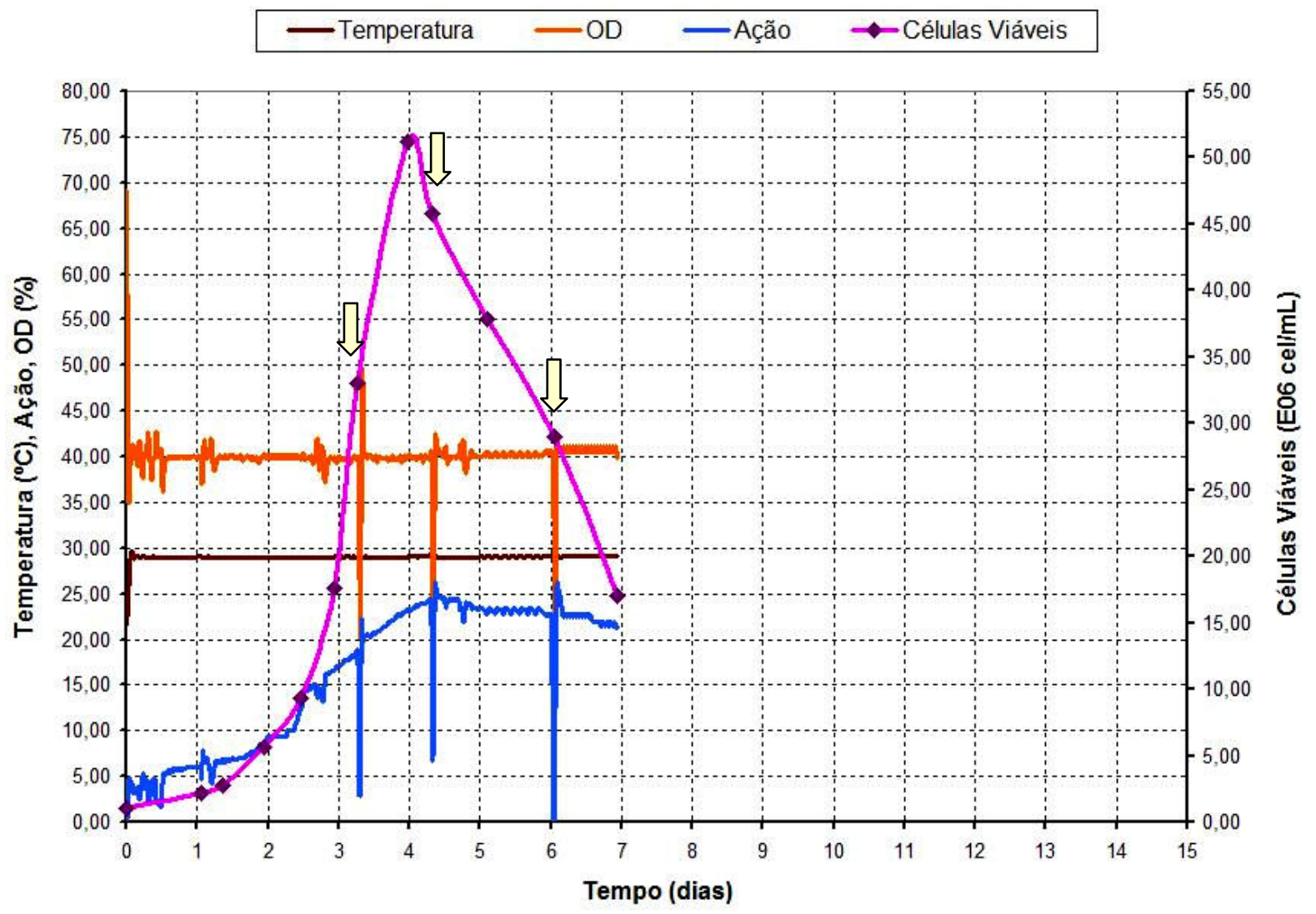

Gráfico 13 - Temperatura, OD, ação do controlador de OD e concentração de células viáveis do Ensaio 3 (S2b) em função do tempo. As setas representam as tomadas de medidas através do Método Dinâmico.

Tabela 3 - Medidas de OUR, kLa e Qo2 do Ensaio 3 (S2b)

\begin{tabular}{ccccc}
\hline $\mathbf{T}$ (dias) & $\mathbf{X}(\mathrm{cel} / \mathrm{mL})$ & OUR $\left(\mathrm{mmolO}_{2} \cdot \mathrm{L}^{-1} \cdot \mathbf{h}^{-1}\right)$ & $\mathbf{k}_{\mathrm{L}} \mathbf{a}\left(\mathbf{h}^{-1}\right)$ & $\mathbf{Q}_{\mathrm{O} 2}\left(\mathrm{molO}_{2} \cdot \mathrm{cel}^{-1} \cdot \mathbf{s}^{-1}\right)$ \\
\hline 3,26 & $33,0 \cdot 10^{6}$ & 0,40 & 0,61 & $3,36 \cdot 10^{-18}$ \\
4,32 & $45,8 \cdot 10^{6}$ & 0,54 & 0,70 & $3,29 \cdot 10^{-18}$ \\
6,05 & $29,0 \cdot 10^{6}$ & 0,30 & 0,37 & $2,90 \cdot 10^{-18}$ \\
\hline
\end{tabular}

Comparativamente, nota-se a influência da alta temperatura na velocidade específica de respiração. Aparentemente, as células que sofreram o aumento da temperatura (acima de $30^{\circ} \mathrm{C}$ ) no Ensaio 2 respiram mais, por isso o $\mathrm{Q}_{02}$ foi $60 \%$ maior no Ensaio 2 que no Ensaio 3.

No Gráfico 14, observa-se as medidas da OUR e Q $\mathrm{O}_{2}$ estimada através do Balanço na Fase Líquida (BFL) conforme descrita na seção 3.5.2. Pode-se observar que os valores encontrados para a OUR e Qo2 através do Método Dinâmico Tradicional não 
estão muito próximos aos verificados pelo Balanço na Fase Líquida, isto indica que os valores encontrados através do Método Dinâmico Tradicional estão super dimensionados.

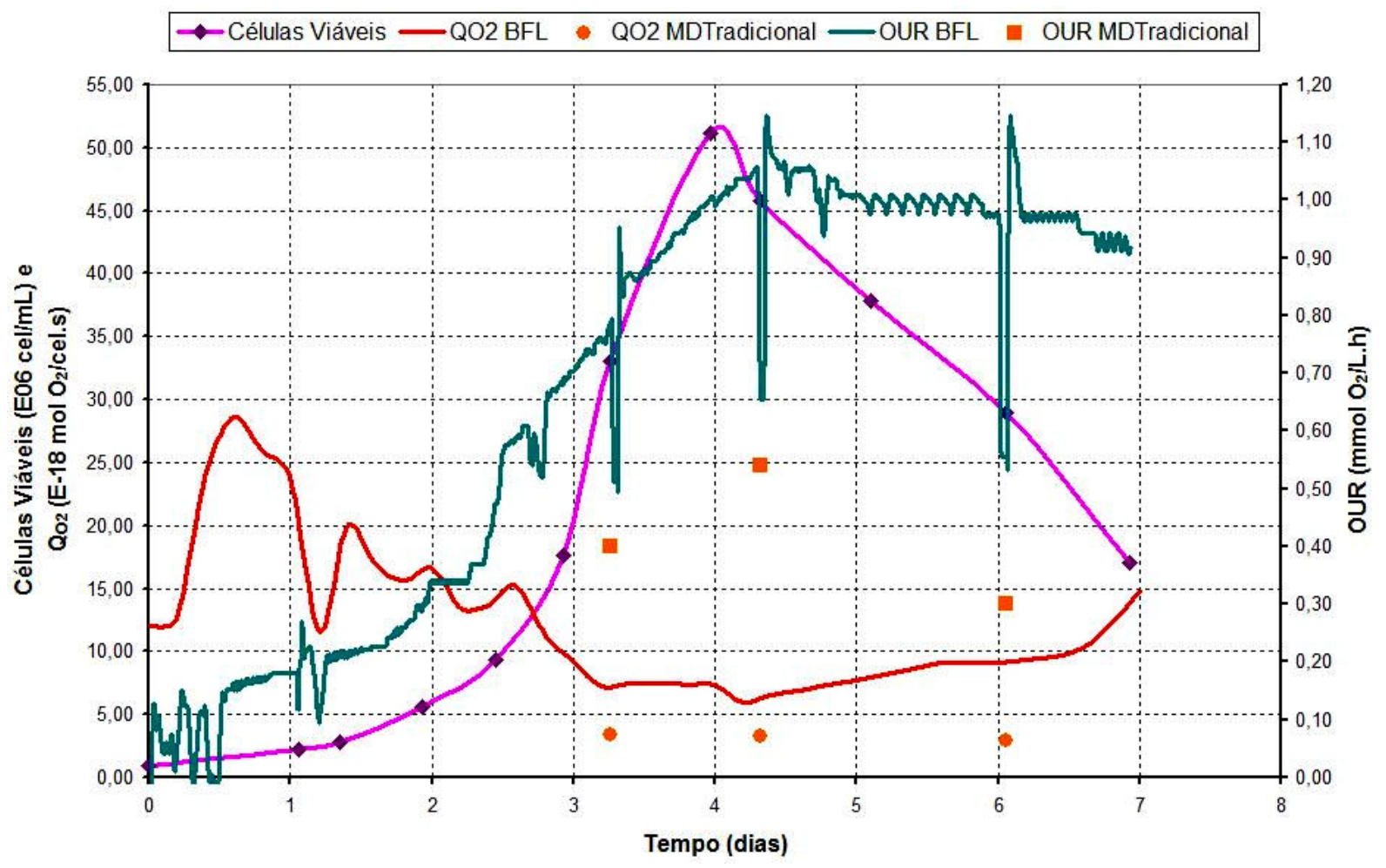

Gráfico 14 - Medidas de OUR e Qo2 por Método Dinâmico Tradicional e Balanço da Fase Líquida do Ensaio 3 (S2b) em função do tempo.

No Gráfico 15, observa-se que a máxima velocidade específica de crescimento celular $\left(\mu_{\max }\right)$ foi de $1,07 \mathrm{dia}^{-1}\left(0,045 \mathrm{~h}^{-1}\right)$ verificada até $03^{\circ}$ dia de cultivo. $\mathrm{O}$ comportamento da velocidade específica de crescimento celular foi diferente que no Ensaio 2, atingindo seu valor máximo na fase exponencial e tendo apenas um patamar.

No Gráfico 16, observa-se o crescimento celular por spline e seu logaritmo neperiano (In) e também a velocidade específica de crescimento celular. 


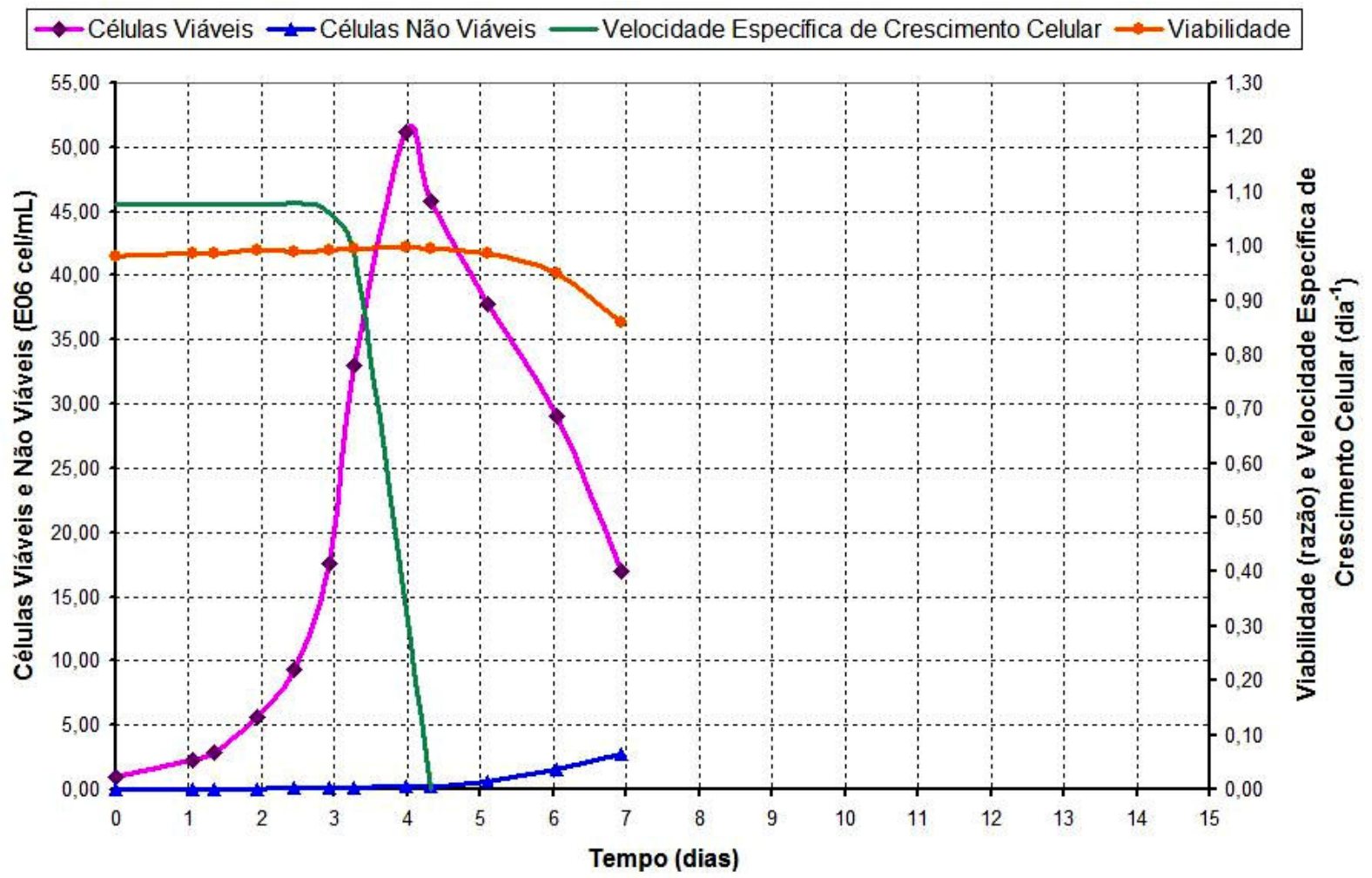

Gráfico 15 - Viabilidade celular e velocidade específica de crescimento celular do Ensaio 3 (S2b) em função do tempo.

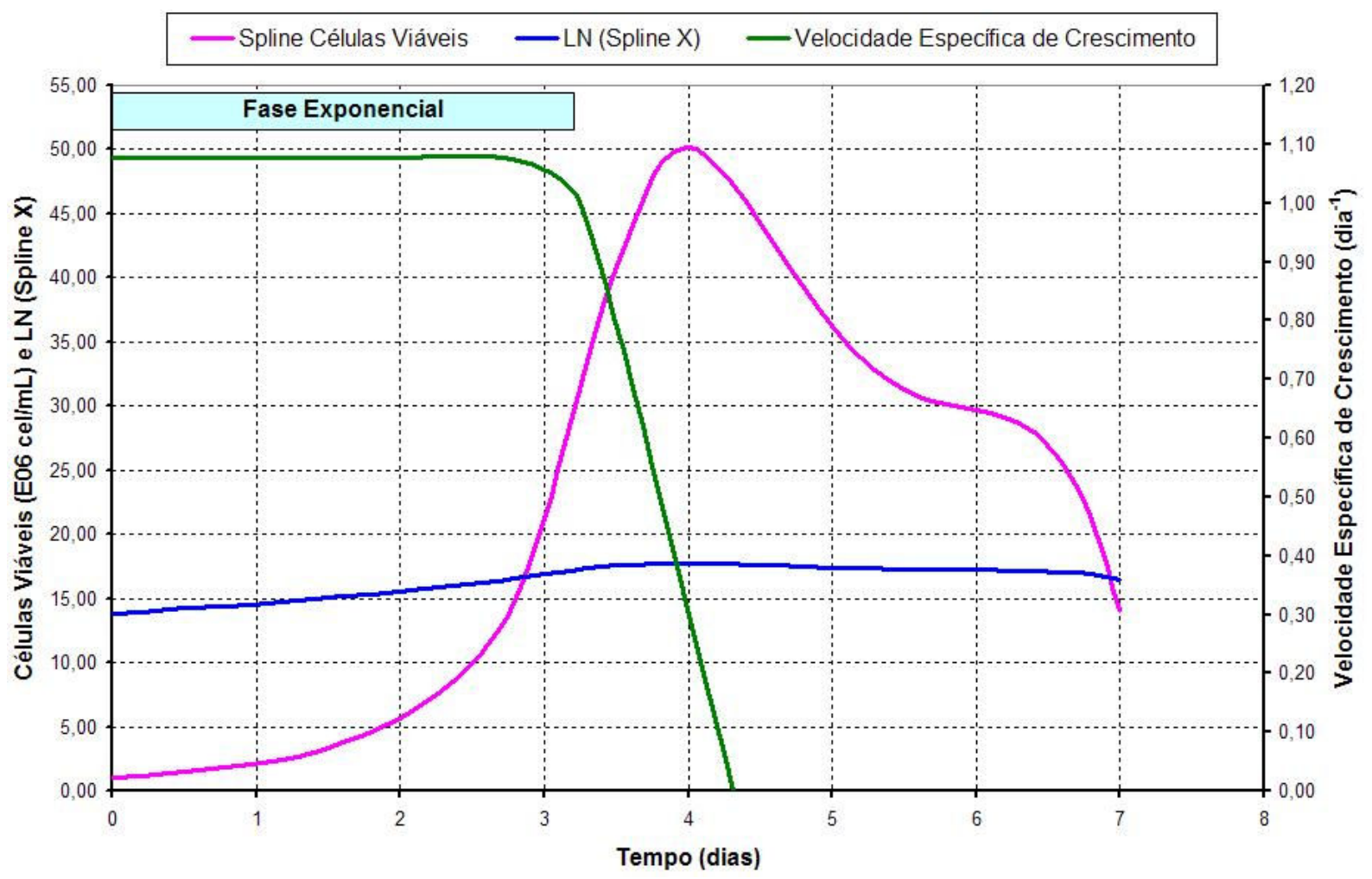

Gráfico 16 - Velocidade específica de crescimento celular do Ensaio 3 (S2b) em função do tempo. 
No Gráfico 17, tem-se o perfil de glicose, lactato e glutamina ao longo do cultivo. A glicose foi consumida chegando a $0,98 \mathrm{~g} / \mathrm{L}$, assim como a glutamina chegou a 1,15 g/L. Comparando-se com o Ensaio 2, a glicose foi consumida mais rapidamente. Lactato foi formado chegando a $0,75 \mathrm{~g} / \mathrm{L}$.

As altas temperaturas atingidas no Ensaio 2 alteraram o crescimento celular e o consumo de glicose e glutamina, fazendo com que tudo ocorresse de maneira mais lenta.

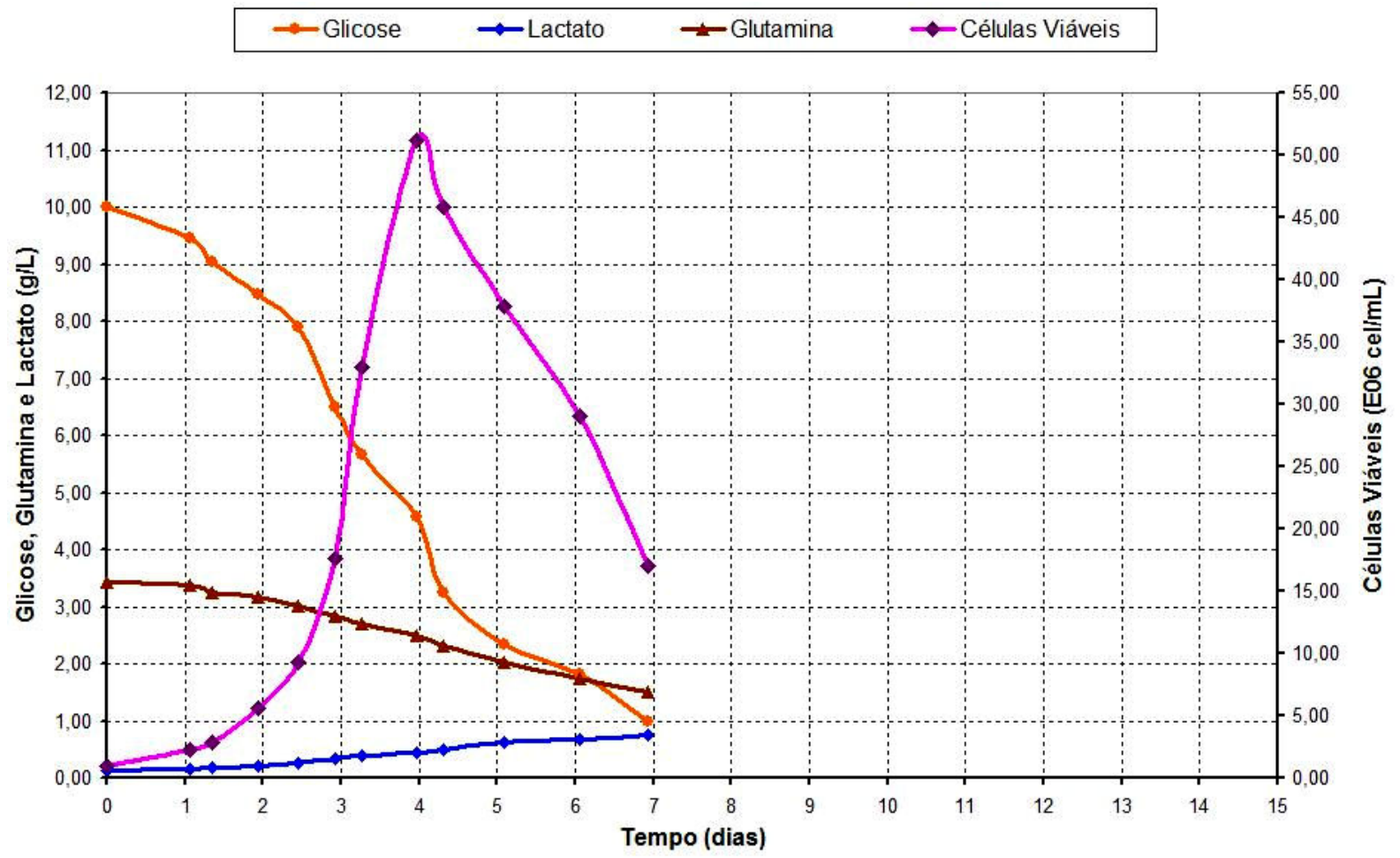

Gráfico 17 - Concentração de glicose, glutamina e lactato do Ensaio 3 (S2b) em função do tempo.

Neste ensaio o monitoramento do $\mathrm{pH}$ foi prejudicado, pois o eletrodo de $\mathrm{pH}$ sofreu algum dano no início do ensaio e só pôde ser trocado posteriormente. Por esse motivo não está apresentado no Gráfico 17.

No Gráfico 18, têm-se os perfis das velocidades específicas de consumo de glicose e glutamina e da velocidade específica de produção de lactato. $\mathrm{Na}$ fase de crescimento celular, as máximas velocidades específicas de consumo de glicose e glutamina foram atingidas no início do cultivo, decaindo depois disso. A velocidade específica máxima de consumo de glicose foi de 5,23.10-10 $\mathrm{g} /$ (cel.dia). Já a velocidade específica de produção de lactato teve seu ponto máximo no início do cultivo, decrescendo após disto. 


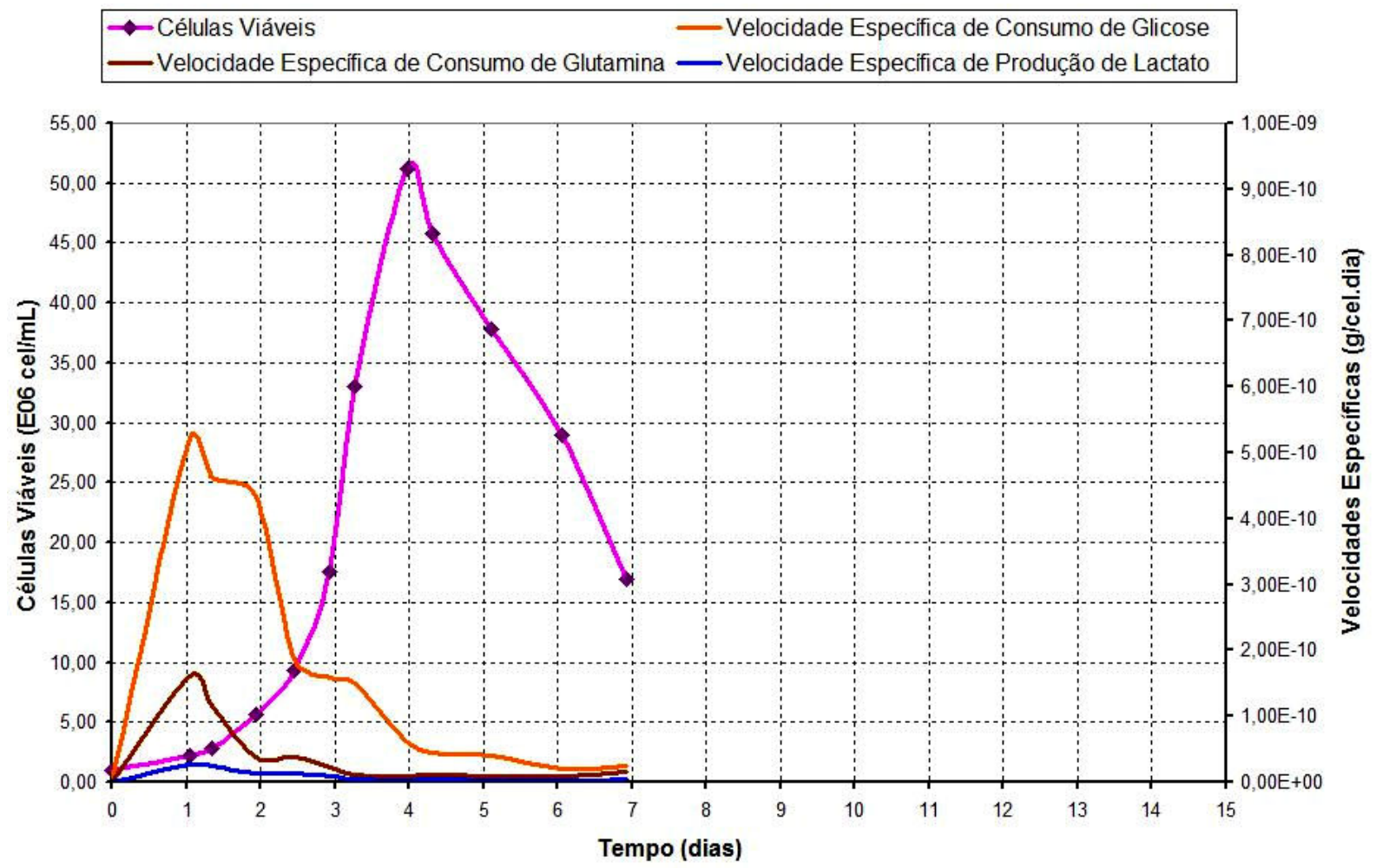

Gráfico 18 - Velocidades específicas de consumo de glicose e glutamina e produção de lactato do Ensaio 3 (S2b) em função do tempo.

$\mathrm{Na}$ Tabela 4 apresenta-se um quadro comparativo entre os resultados dos Ensaios 2 e 3, podendo-se observar que no Ensaio 2, com as altas temperaturas alcançadas, o $\mathrm{Q}_{\mathrm{O} 2}$ foi maior que no Ensaio 3. Como as células tiveram um crescimento mais regular no Ensaio 3, elas conseguiram atingir uma concentração também mais alta.

Tabela 4 - Comparação entre Ensaios 2 e 3

\begin{tabular}{lcc}
\hline & Ensaio 2 & Ensaio 3 \\
\hline $\mathrm{X}_{\text {inicial }}(\mathrm{cel} / \mathrm{mL})$ & $0,24.10^{6}$ & $0,98.10^{6}$ \\
$\mathrm{X}_{\text {máx }}(\mathrm{cel} / \mathrm{mL})$ & $44,80.10^{6}$ & $51,20.10^{6}$ \\
$\mathrm{OUR}_{\text {máx em fase exponencial }}\left(\mathrm{mmolO}_{2} /(\mathrm{L} . \mathrm{h})\right)$ & 0,40 & 0,40 \\
$\mathrm{Q}_{\mathrm{O} 2 \text { máx em fase exponencial }}\left(\mathrm{mol} \mathrm{O}_{2} /(\mathrm{cel} . \mathrm{s})\right)$ & $6,45.10^{-18}$ & $3,36.10^{-18}$ \\
$\mathrm{k}_{\mathrm{L} \text { a }\left(\mathrm{h}^{-1}\right)}$ & 0,67 & 0,61 \\
$\mu_{\text {máx }}\left(\mathrm{dia}^{-1}\right)$ & $1,03 / 0,34$ & 1,07 \\
\hline
\end{tabular}

Pode-se perceber que no Ensaio 2 a velocidade máxima específica de crescimento celular estava em 1,03 dia $^{-1}$ quando sofreu influência da temperatura decaindo para 
$0,34 \mathrm{dia}^{-1}$. Já no Ensaio 3 a velocidade máxima específica de crescimento celular foi de 1,07 dia $^{-1}$, valor este muito próximo do início do Ensaio 2. Isso confirma a ação inibitória de altas temperaturas (acima de $30^{\circ} \mathrm{C}$ ).

Nota-se que as células S2 possuem um Qo2 menor que as células Sf9. Pode-se observar a verdade desta afirmação não apenas pelo valor numérico, mas pela comparação entre a ação nos ensaios 1, 2 e 3. No Ensaio 1 houve a necessidade de um aumento da sobrepressão na membrana de silicone para suprir as exigências de oxigênio e nos Ensaios 2 e 3, esta mesma ação, não chegou a ser totalmente utilizada (lembrando-se que a ação é limitada em 40\%).

O valor de $\mathrm{Q}_{\mathrm{O} 2}$ para as células S2 pode ser considerado baixo, ou seja, cerca de dez vezes menor, que para os padrões da Sf9, que tem $Q_{02}$ em torno de 3,5 e 9,9.10-17 mol $\mathrm{O}_{2} /$ (cel.s) (KIOUKIA et al., 1995), porém Deutschmann e Jäger (1994) em ensaios em biorreator com células Sf21 infectadas com baculovírus chegaram a $0,83.10^{-17} \mathrm{~mol} \mathrm{O}_{2} /$ (cel.s), sendo que células infectadas, normalmente, respiram mais que as não infectadas (MARQUES, 2005).

Deve-se salientar que após o Ensaio 1 a membrana foi trocada e que possui, como já mostrado no item 3.2.1, uma área maior em relação à antiga membrana.

Nota-se ainda, a diferença entre as velocidades específicas de crescimento celular entre esses ensaios. Existe a possibilidade da temperatura, que atingiu valores de $35^{\circ} \mathrm{C}$ no Ensaio 2, ter atuado como fator inibitório ao crescimento.

Outro fator que deve ser ressaltado é o crescimento celular nos Ensaio 2 e 3, sendo que no Ensaio 3 atingiu $51,20.10^{6} \mathrm{cel} / \mathrm{mL}$. É um valor alto para os padrões de crescimento de células de inseto como a Sf9 (KIOUKIA et al. 1995), porém em outras células como a Sf21, infectadas com baculovírus, chegou-se a 55,0.10 6 $\mathrm{cel} / \mathrm{mL}$ (DEUTSCHMANN; JÄGER, 1994). A velocidade específica de crescimento celular $(\mu)$ atingiu 1,03 dia $^{-1}$ no Ensaio 2, no primeiro dia de cultivo, porém, no Ensaio 3 , chegou-se a 1,07 dia $^{-1}$ no $3^{\circ}$ dia de cultivo. O valor do Ensaio 2 é compatível com os valores alcançados por Bovo (2006) em cultivo em Schott de S2 selvagem com meio TC100 suplementado com glicose para atingir $9 \mathrm{~g} / \mathrm{L}$ ao início do ensaio. Sendo que o meio de cultura TC100 possui menos nutrientes que o SF900 II, conseqüentemente, seria de se esperar que em SF900 II a célula cresceria com uma velocidade específica maior. E ainda, em Schott, tem-se a possibilidade de limitação 
de oxigênio, o que não ocorreu no biorreator. Este é mais um motivo para atestar o efeito inibitório da temperatura alta em um cultivo de S2 selvagem.

\subsection{1 $\mathrm{C}_{\text {crítico }}$}

Conforme apresentado na seção 3.5.4, foi implementado durante o Ensaio 3 um método experimental de cálculo de $\mathrm{C}_{\text {crít. }}$ Conforme pode ser visto no Gráfico 19 , quando se interrompe a transferência de oxigênio, o OD decai quase como uma reta mudando sua inclinação quando a célula é obrigada a sair de sua velocidade máxima específica de respiração, obtendo-se, assim, o $\mathrm{C}_{\text {crít. }}$

O valor de $\mathrm{C}_{\text {crit, }}$ assim calculado está em torno de $10 \%$ da saturação com ar. As medidas foram feitas em três pontos diferentes do cultivo e em todas às vezes a curva mudou sua inclinação praticamente no mesmo ponto. As medições estão apresentadas no Apêndice F.

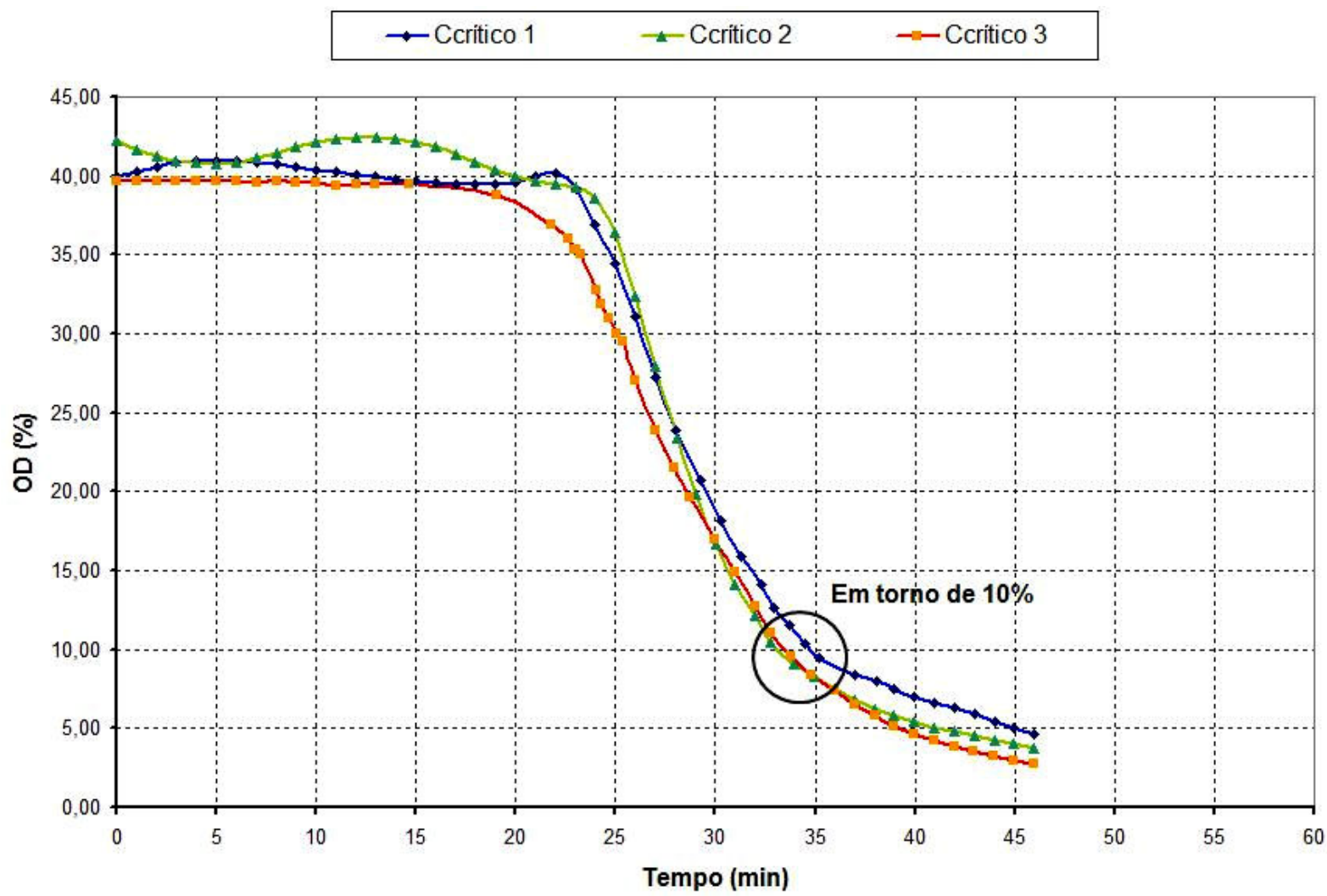

Gráfico 19 - Cálculo do $\mathrm{C}_{\text {critico }}$ em três diferentes pontos do cultivo no Ensaio 3 (S2b) sendo:

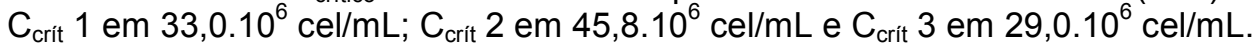




\subsection{ENSAIO 4 (GPV)}

Após o trabalho e dados colhidos com as células S2 selvagens, procedeu-se ao ensaio com células recombinantes. Foi feito, então, o ensaio com as células S2AcGPV2 transfectadas, segundo Yokomizo et al. (2007), no Laboratório de Imunologia Viral do Instituto Butantan.

Este ensaio foi realizado em meio de cultura SF900 II sem soro fetal bovino e foi controlado a $40 \%$ de OD com sobrepressão na membrana de silicone de 0,5 bar. Este ensaio transcorreu com os controles com desempenho satisfatório.

No Gráfico 20 podem ser observados todos os controles. Nota-se, mais uma vez, que os picos descendentes em OD e ação são devidos ao Método Dinâmico com a nova maneira desenvolvida para cálculo do $C_{\text {crit, }}$ conforme seção 3.5.5. Durante este ensaio foi implementado o Método Dinâmico Proposto como visto na seção 3.5.4. A concentração celular inicial foi de $0,50.10^{6} \mathrm{cel} / \mathrm{mL}$, chegando a $26,60.10^{6} \mathrm{cel} / \mathrm{mL}$ no $8^{\circ}$ dia de cultivo.

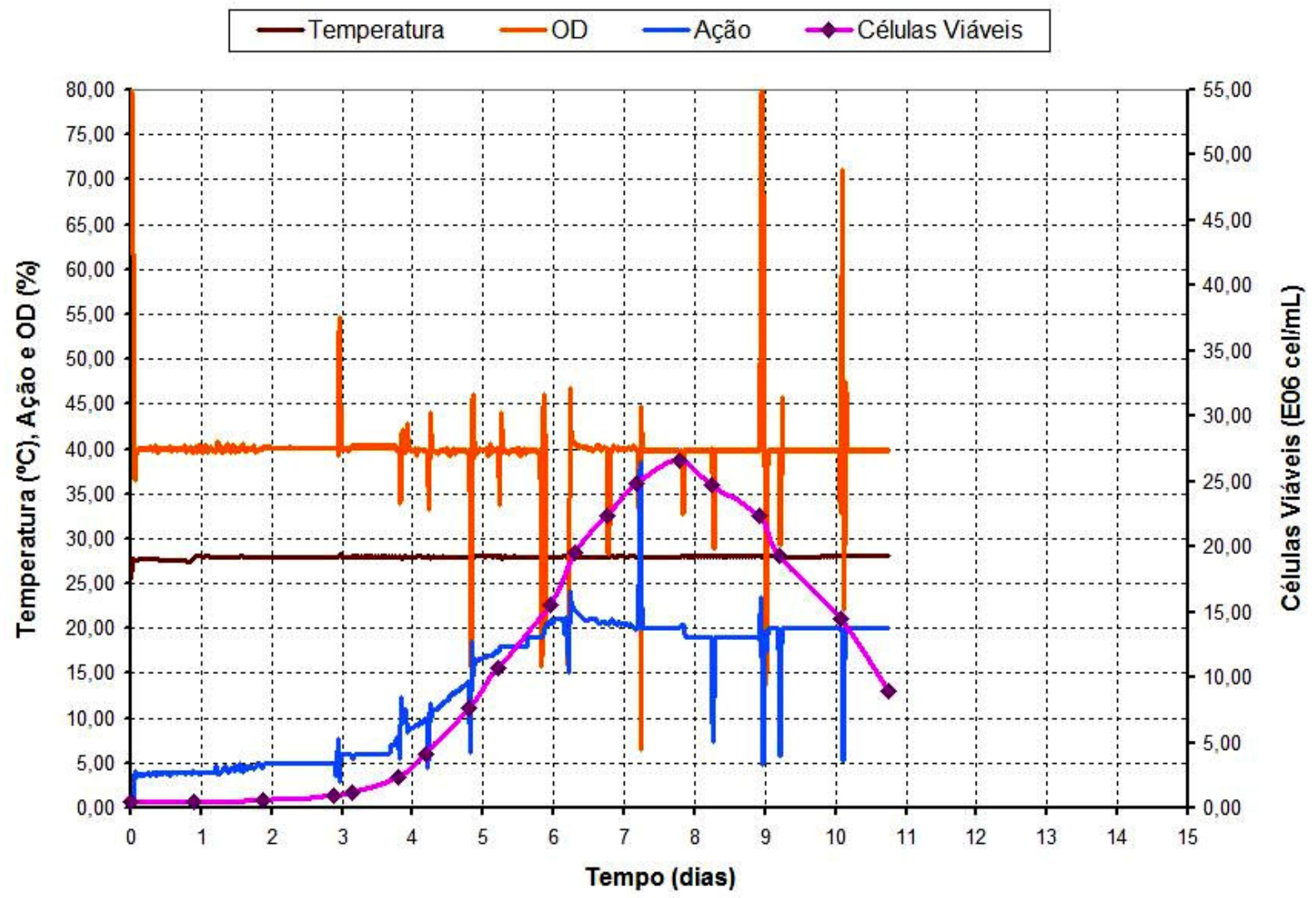

Gráfico 20 - Temperatura, OD, ação do controlador de OD e concentração de células viáveis do Ensaio 4 (GPV) em função do tempo. 
OUR, $\mathrm{k}_{\mathrm{L}} \mathrm{a}$ e $\mathrm{Q}_{\mathrm{O} 2}$ foram medidos em catorze instantes do ensaio (Apêndice $\mathrm{G}$ ) conforme o Método Dinâmico descrito na seção 2.11 e também com a anulação completa da transferência descrita na seção 3.5.4. Os resultados são apresentados na Tabela 5.

Tabela 5 - Medidas de OUR, $\mathrm{k}_{\mathrm{L}}$ a e QO2 do Ensaio 4 (GPV)

\begin{tabular}{|c|c|c|c|c|c|}
\hline $\begin{array}{c}\mathrm{T} \\
\text { (dias) }\end{array}$ & $\begin{array}{c}X \\
(\text { cel/mL) }\end{array}$ & $\begin{array}{c}\text { OUR } \\
\left(\mathrm{mmolO}_{2} \cdot \mathrm{L}^{-1} \cdot \mathrm{h}^{-1}\right)\end{array}$ & $\begin{array}{l}k_{L} a \\
\left(h^{-1}\right)\end{array}$ & $\begin{array}{c}Q_{\mathrm{O} 2} \\
\left(\mathrm{molO}_{2} \cdot \mathrm{cel}^{-1} \cdot \mathrm{s}^{-1}\right)\end{array}$ & $\begin{array}{c}\text { Método } \\
\text { Dinâmico } \\
\text { utilizado }\end{array}$ \\
\hline 2,87 & $0,94 \cdot 10^{6}$ & 0,01 & 0,12 & $3,67.10^{-18}$ & Tradicional \\
\hline 3,79 & $2,41.10^{6}$ & 0,07 & 0,30 & $7,85 \cdot 10^{-18}$ & Método Proposto \\
\hline 4,19 & $4,16 \cdot 10^{6}$ & 0,07 & 0,22 & $4,45 \cdot 10^{-18}$ & Tradicional \\
\hline 4,79 & $7,68 \cdot 10^{6}$ & 0,43 & 0,91 & $15,18 \cdot 10^{-18}$ & Método Proposto \\
\hline 5,20 & $10,68 \cdot 10^{6}$ & 0,08 & 0,14 & $2,10 \cdot 10^{-18}$ & Tradicional \\
\hline 5,95 & $15,60.10^{6}$ & 0,90 & 1,37 & $16,04 \cdot 10^{-18}$ & Método Proposto \\
\hline 6,29 & $19,60.10^{6}$ & 0,07 & 0,09 & $0,99 \cdot 10^{-18}$ & Tradicional \\
\hline 6,77 & $22,35.10^{6}$ & 1,03 & 1,36 & $12,46 \cdot 10^{-18}$ & Método Proposto \\
\hline 7,23 & $24,86.10^{6}$ & 0,92 & 1,24 & $10,23 \cdot 10^{-18}$ & Método Proposto \\
\hline 7,79 & $26,60.10^{6}$ & 0,05 & 0,06 & $0,49 \cdot 10^{-18}$ & Tradicional \\
\hline 8,25 & $24,72.10^{6}$ & 0,96 & 1,46 & $10,78 \cdot 10^{-18}$ & Método Proposto \\
\hline 8,91 & $22,40.10^{6}$ & 0,14 & 0,19 & $1,72.10^{-18}$ & $\begin{array}{l}\text { Tradicional a } \\
\text { partir } 80 \% \text { OD }\end{array}$ \\
\hline 9,20 & $19,30.10^{6}$ & 0,95 & 1,37 & $13,71 \cdot 10^{-18}$ & Método Proposto \\
\hline 10,02 & $14,50.10^{6}$ & 0,67 & 1,09 & $12,73 \cdot 10^{-18}$ & $\begin{array}{c}\text { Método Proposto } \\
\text { a partir } 80 \% \mathrm{OD}\end{array}$ \\
\hline
\end{tabular}

Observa-se que o Q 02 obtido pelo Método Dinâmico Tradicional foi sempre menor que o encontrado através da proposta da completa anulação da transferência. Também a OUR foi menor no Método Dinâmico Tradicional, o que mostra que, mesmo despressurizando a linha, desligando a agitação e cortando o fornecimento de oxigênio, ainda existe uma transferência de oxigênio para a cultura, vindo da 
cabeça do reator e também da própria membrana. Como descrito na seção 3.5.2 a medida feita por BFL é a mais confiável, pois utiliza a variação da pressão parcial de oxigênio através da mudança na fração mássica de oxigênio no gás de aeração. Portanto, na comparação com o BFL, Gráfico 21, essas evidências se confirmam. E ainda, o $\mathrm{k}_{\mathrm{L}}$ a encontrado com o Método Proposto é muito mais próximo ao $\mathrm{k}_{\mathrm{L}}$ a fixo do sistema do que no Método Tradicional.

No Gráfico 21 observam-se as medidas da OUR e no Gráfico 22 observam-se as medidas de $\mathrm{Q}_{\mathrm{O} 2}$ estimadas através do Balanço na Fase Líquida (BFL) conforme descrita na seção 3.5.2. Pode-se observar que os valores encontrados para a OUR e $Q_{02}$ através do Método Dinâmico Tradicional estão bem distantes aos verificados pelo Balanço na Fase Líquida, isto mostra que os valores encontrados através do Método Dinâmico Tradicional estão super dimensionados, enquanto os valores encontrados através do Método Dinâmico Proposto estão muito próximos aos obtidos através do Balanço na Fase Líquida.

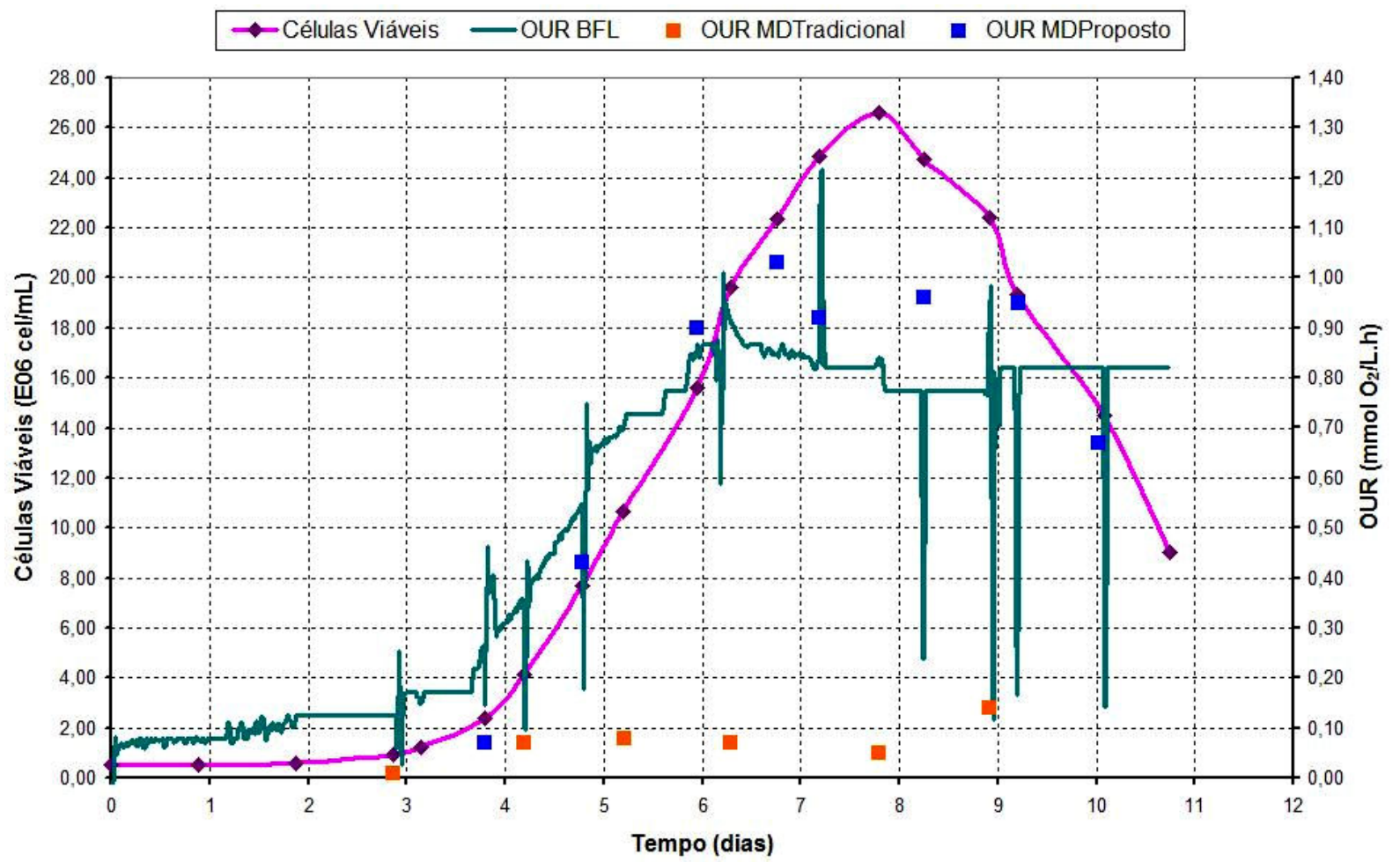

Gráfico 21 - Medidas de OUR por Método Dinâmico Tradicional e Balanço da Fase Líquida do Ensaio 4 (GPV) em função do tempo. 


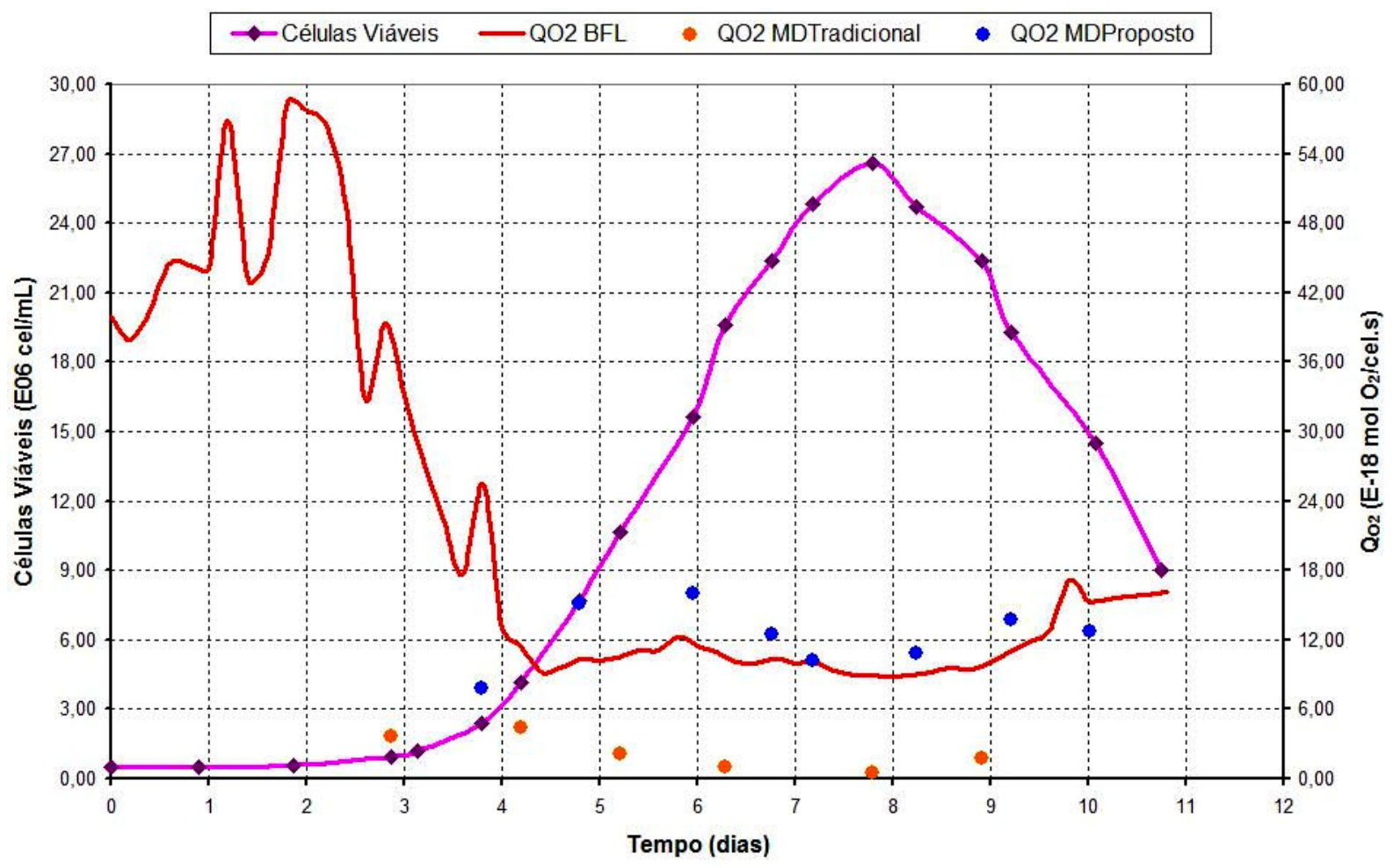

Gráfico 22 - Medidas de $Q_{02}$ por Método Dinâmico Tradicional e Balanço da Fase Líquida do Ensaio 4 (GPV) em função do tempo.

No Gráfico 23, observa-se que a máxima velocidade específica de crescimento celular $\left(\mu_{\max }\right)$ foi de $1,26 \mathrm{dia}^{-1}\left(0,053 \mathrm{~h}^{-1}\right)$ verificado em torno do $5^{\circ}$ dia de cultivo na fase exponencial de crescimento. A viabilidade manteve-se em torno de $97 \%$ até o $9^{\circ}$ dia de cultivo, quando a concentração de células viáveis começou a decair rapidamente.

Pode-se observar uma fase lag de quase dois dias devido à adaptação das células no reator, apesar do inóculo ter sido de $0,50.10^{6} \mathrm{cel} / \mathrm{mL}$. Nota-se também que a viabilidade inicial era de $100 \%$ e que durante a fase lag ela decaiu para $96 \%$ voltando a aumentar a partir do terceiro dia. O esperado seria que não houvesse esses dois dias onde aproximadamente $4 \%$ das células morreram e que o ensaio já começasse com as células crescendo, como aconteceu a partir do segundo dia.

A possível explicação para este tempo gasto pelas células para começarem a crescer e também pelos $4 \%$ a menos de viabilidade no início do ensaio, será discutido na seção 4.8 a frente.

No Gráfico 24, observa-se o crescimento celular por spline e seu logaritmo neperiano (In) e também a velocidade específica de crescimento celular. 


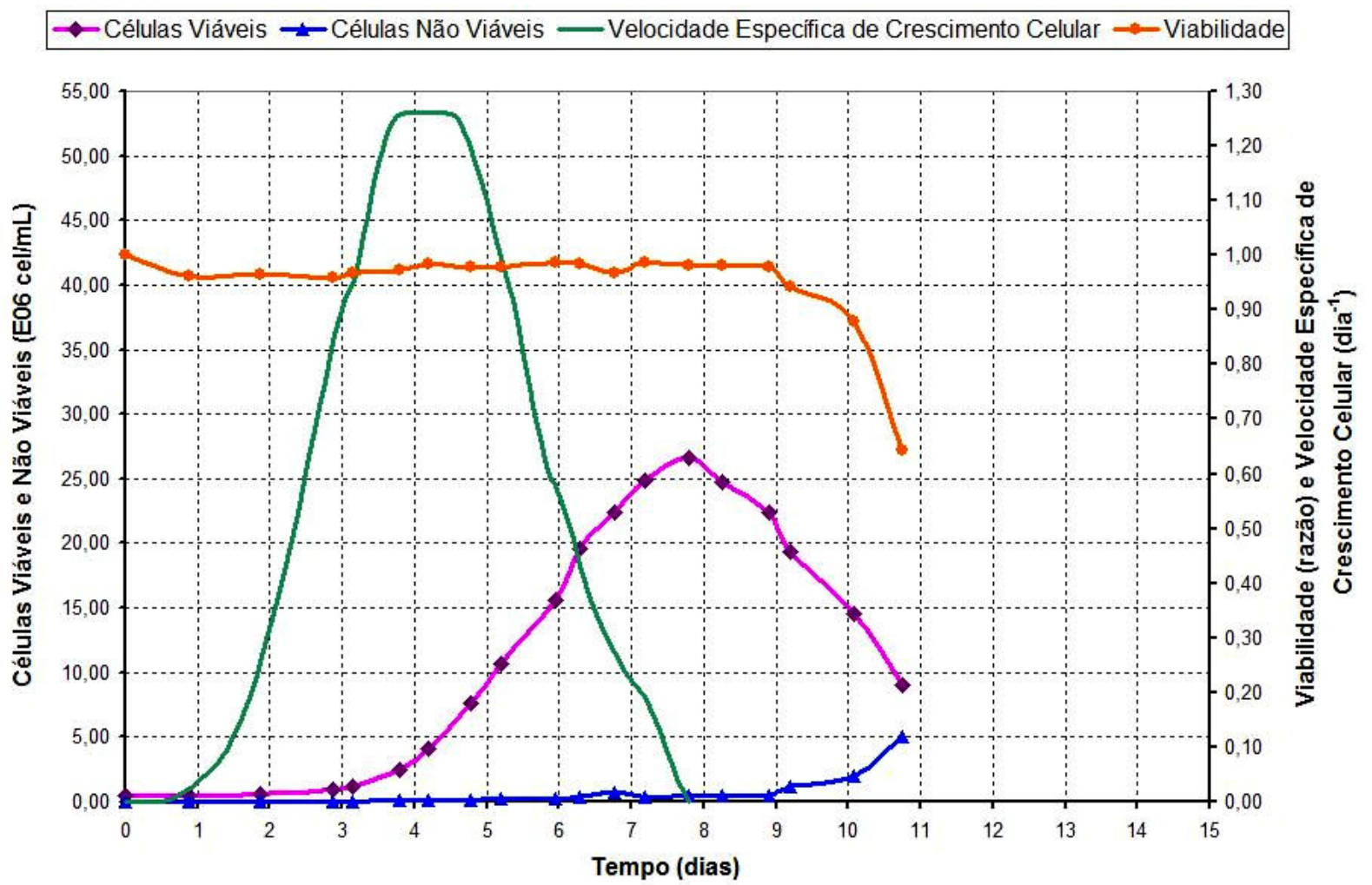

Gráfico 23 - Viabilidade celular e velocidade específica de crescimento celular do Ensaio 4 (GPV) em função do tempo.

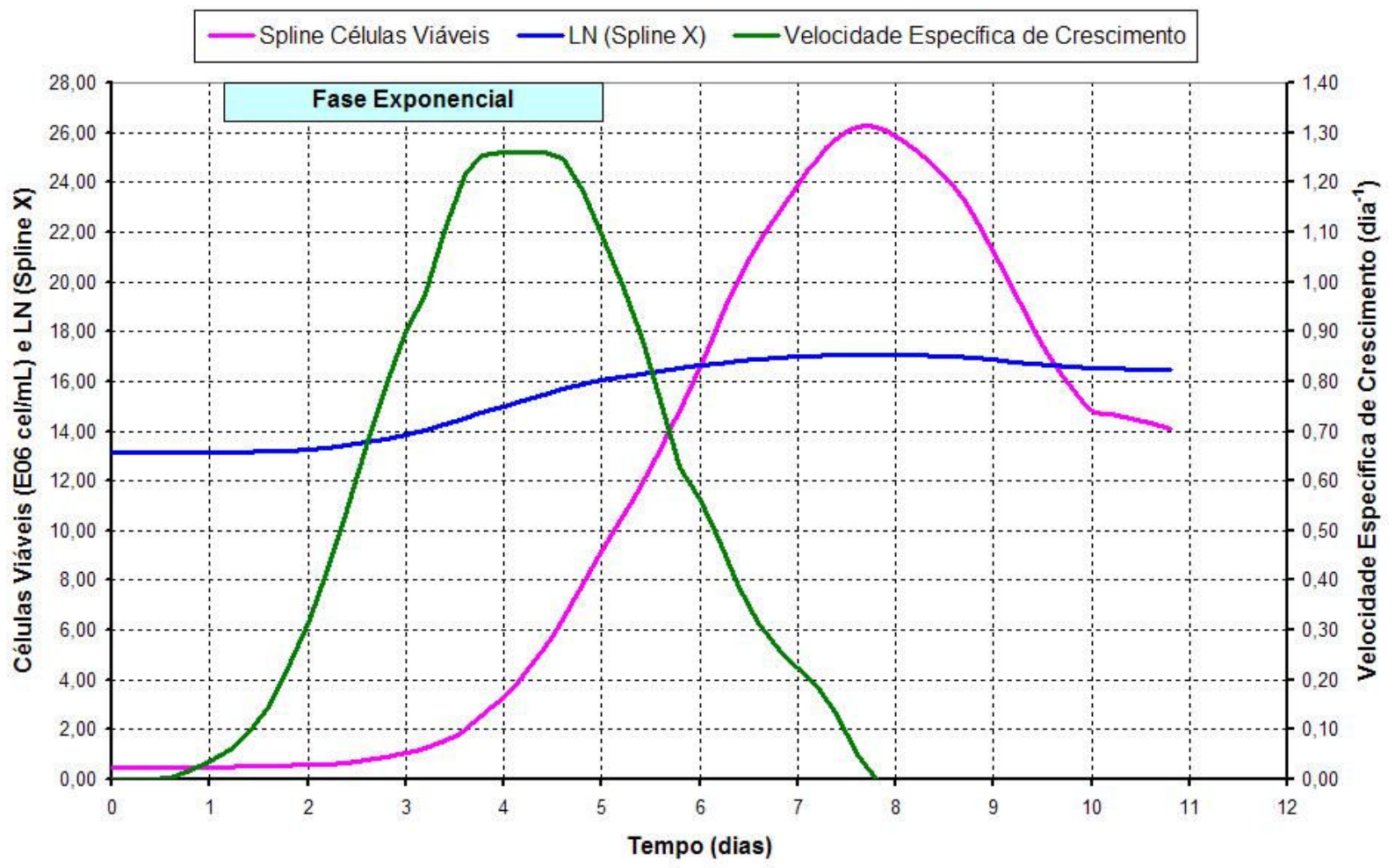

Gráfico 24 - Velocidade específica de crescimento celular do Ensaio 4 (GPV) em função do tempo. 
No Gráfico 25, tem-se o perfil de glicose, lactato e glutamina ao longo do cultivo. A glicose foi consumida chegando a 0,34 $\mathrm{g} / \mathrm{L}$, assim como a glutamina que chegou a $0,94 \mathrm{~g} / \mathrm{L}$. O ensaio iniciou-se com $0,04 \mathrm{~g} / \mathrm{L}$ de lactato e terminou com 0,03 g/L, portanto não foi produzido, apresentando uma pequena diferença entre o início e término do ensaio.

$\mathrm{O}$ pH iniciou-se em 5,99, chegando a 7,06 no $10^{\circ}$ dia de cultivo e terminando em 6,82 após 11 dias de cultivo.

No Gráfico 26, têm-se os perfis das velocidades específicas de consumo de glicose, glutamina e lactato. A velocidade específica máxima de consumo de glicose foi de $7,51.10^{-10} \mathrm{~g} /($ cel.dia) verificada no início da fase exponencial. Na fase de crescimento celular, as máximas velocidades específicas de consumo de glicose e glutamina foram atingidas no início da fase exponencial, decaindo depois disso. A velocidade específica de lactato é muito baixa, por esse motivo quase não aparece no Gráfico 26.

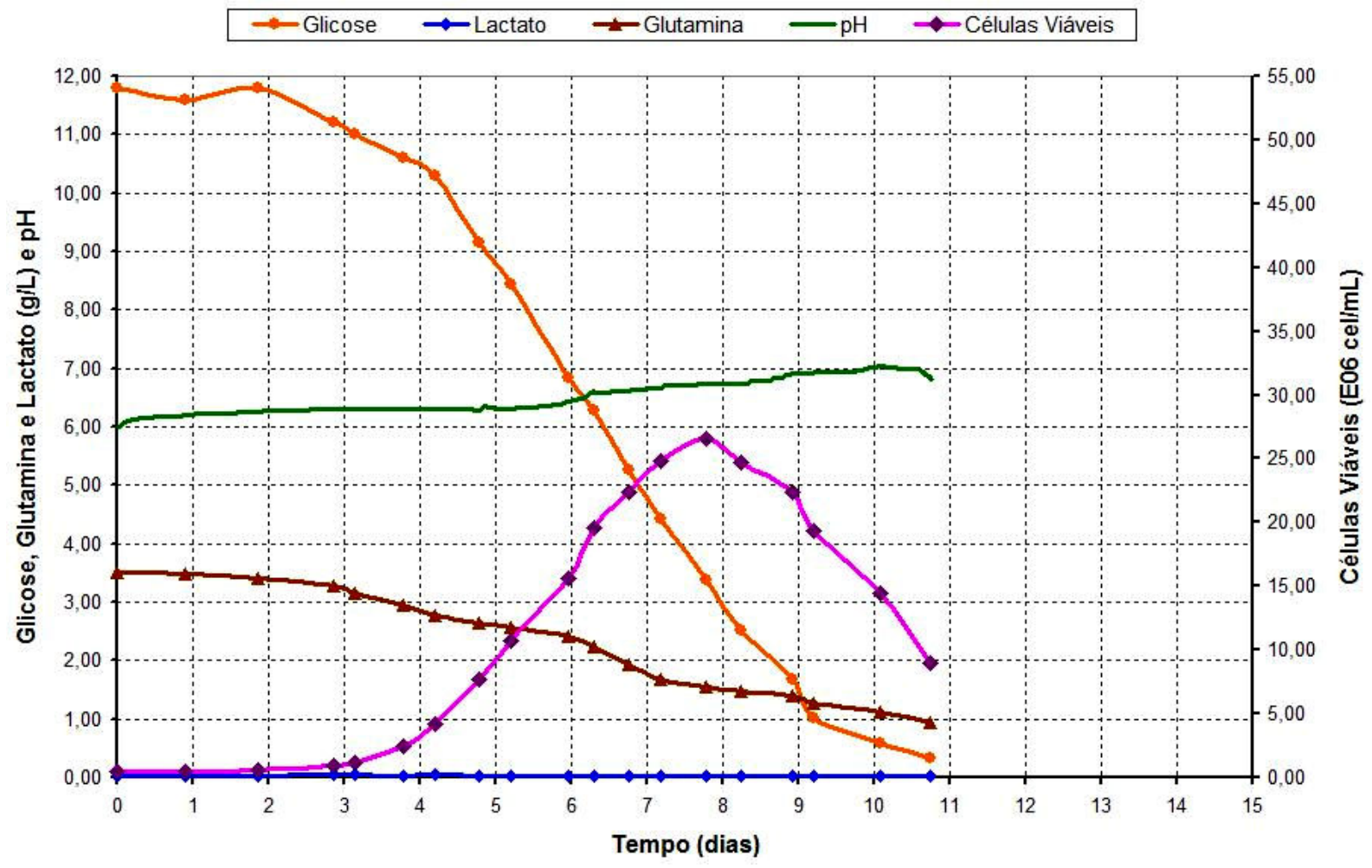

Gráfico 25 - pH e concentração de glicose, glutamina e lactato do Ensaio 4 (GPV) em função do tempo 


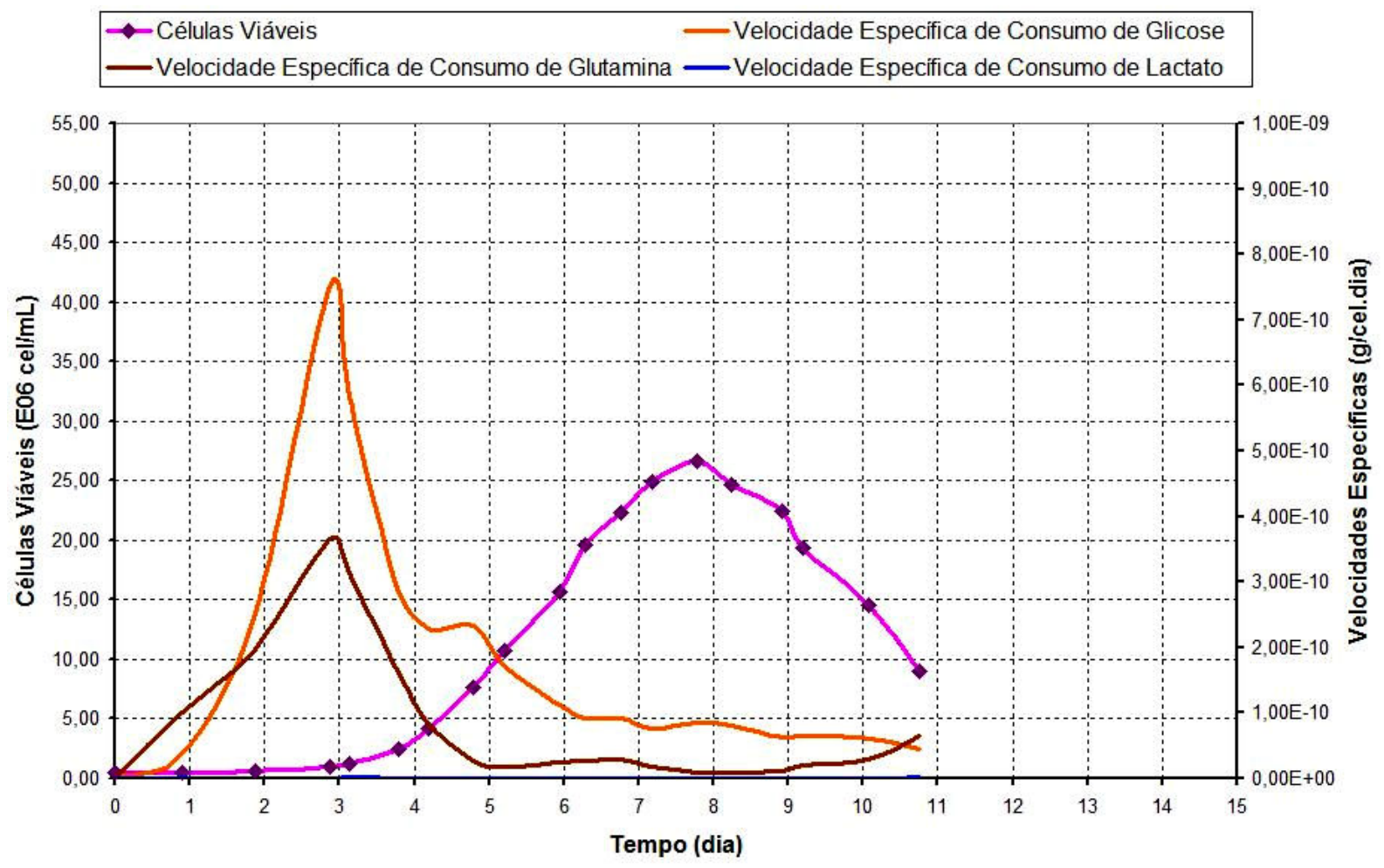

Gráfico 26 - Velocidades específicas de consumo de glicose, glutamina e lactato do Ensaio 4 (GPV) em função do tempo

\subsection{1 $\mathrm{C}_{\text {crítico }}$}

Conforme pode ser visto no Gráfico 27, quando se anula completamente a transferência de oxigênio, o OD decai quase como uma reta mudando sua inclinação quando a célula é obrigada a sair de sua velocidade máxima específica de respiração, obtendo-se, assim, o $\mathrm{C}_{\text {crit. }}$. 


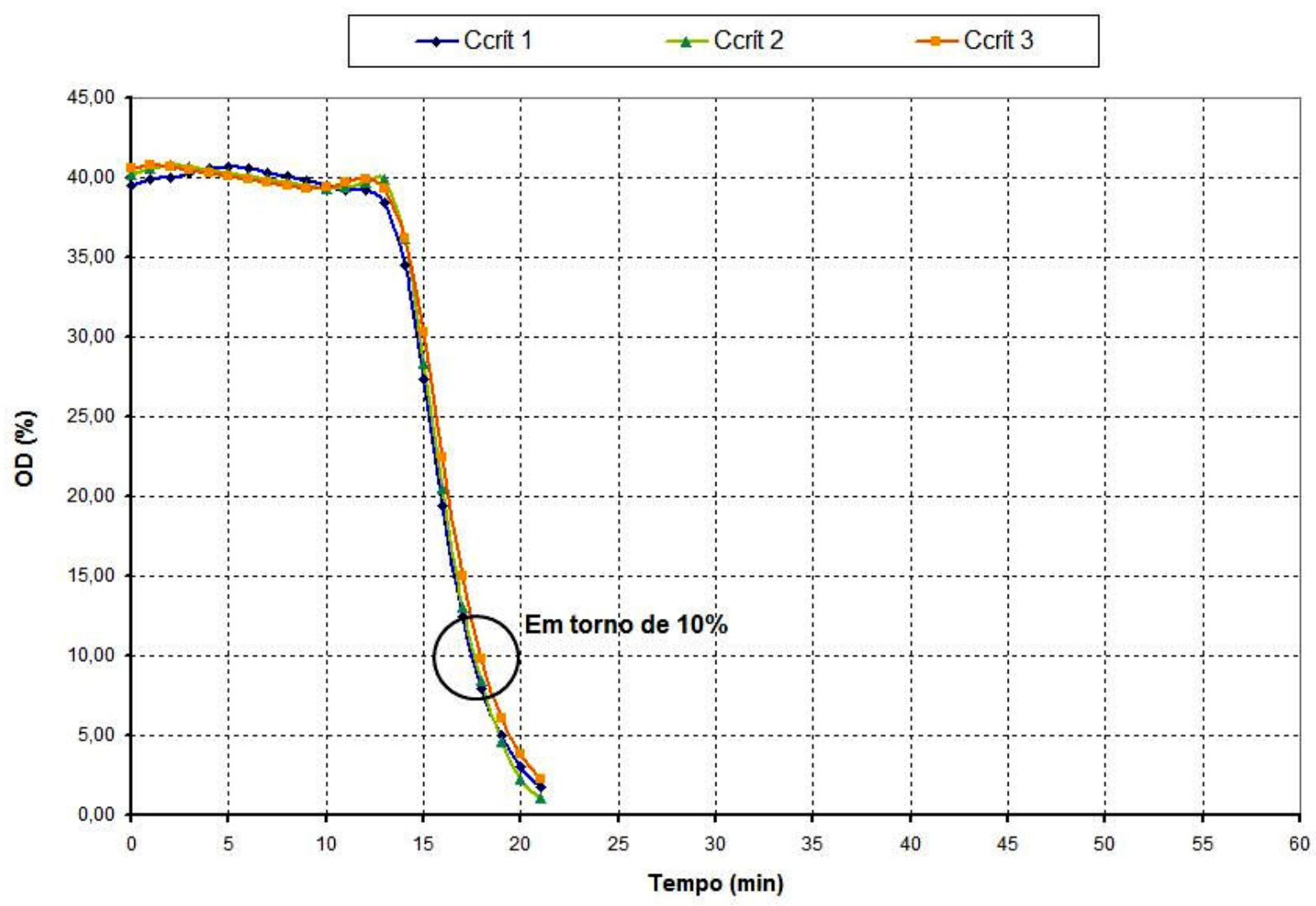

Gráfico 27 - Cálculo do $C_{\text {crit }}$ em três diferentes pontos do cultivo no Ensaio 4 (GPV) sendo: $C_{\text {crit }} 1$ em $22,35.10^{6} \mathrm{cel} / \mathrm{mL} ; \mathrm{C}_{\text {crit }} 2 \mathrm{em} 24,86.10^{6} \mathrm{cel} / \mathrm{mL} \mathrm{e} \mathrm{C}_{\text {crit }} 3 \mathrm{em} 19,30.10^{6} \mathrm{cel} / \mathrm{mL}$.

O valor de $C_{\text {crít }}$ assim calculado está em torno de $10 \%$ da saturação com ar. As medidas foram feitas em vários pontos diferentes do cultivo (Apêndice G), a partir de $40 \%$ OD, e em todas às vezes a curva mudou sua inclinação praticamente no mesmo ponto.

Deixou-se também controlar o OD em $80 \%$ e depois se procedeu à medida, uma vez pelo método dinâmico tradicional e outra pelo método dinâmico proposto. Em ambas às vezes, as curvas, apesar de terem inclinações diferentes, mudaram sua inclinação no mesmo ponto, em torno de 10\% OD como pode ser verificado no Gráfico 28. Portanto, o valor de $\mathrm{C}_{\text {crit }}$ encontrado dessa maneira, independe de que maneira é aplicado o Método Dinâmico. 


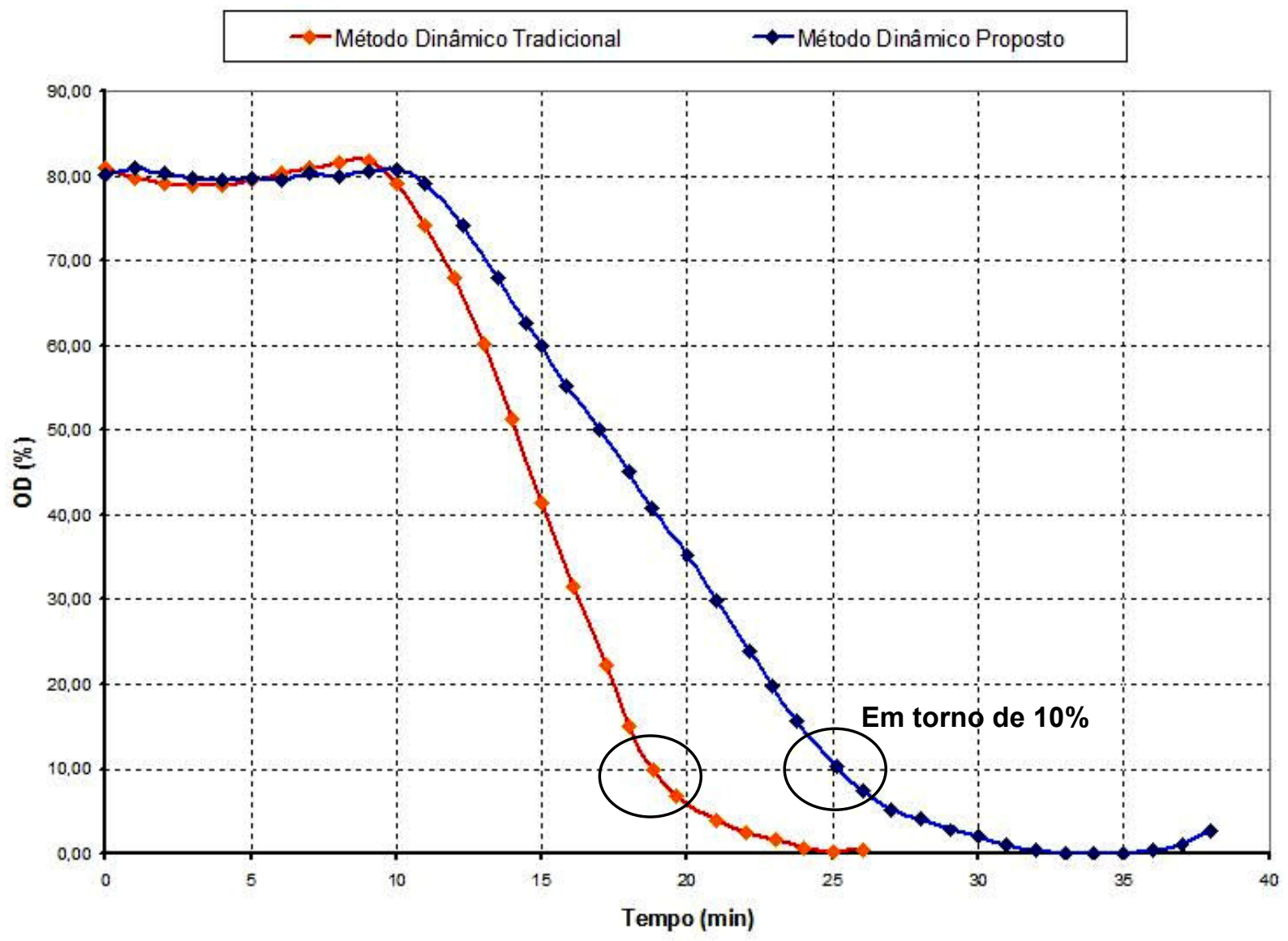

Gráfico 28 - Comparação dos $\mathrm{C}_{\text {crit }}$ encontrados através dos diferentes Métodos Dinâmicos aplicados no cultivo do Ensaio 4 (GPV) sendo Método Dinâmico Tradicional em 8,91 dias e Método Dinâmico Proposto em 10,08 dias.

\subsubsection{Expressão de GPV}

No Gráfico 29 tem-se a quantidade de GPV expressa durante o ensaio, conforme análise feita com o teste ELISA no Laboratório de Imunologia Viral do Instituto Butantan realizado em 26/10/06 a partir de um pellet de $10^{7}$ células e descrito na seção 3.4.3.

Chegou-se a produzir $57 \mathrm{ng} \mathrm{GPV} / 10^{7} \mathrm{cel}$ no final da fase exponencial. Esse valor é condizente ao encontrado por colegas do projeto temático em condições semelhantes de cultivo (informação verbal) ${ }^{1}$.

\footnotetext{
${ }^{1}$ Informação recebida da Dra. Kamilla Swiech no III Workshop sobre biologia molecular e engenharia de bioprocessos para a produção de proteínas recombinantes com células de insetos, 2006, São Carlos/SP.
} 


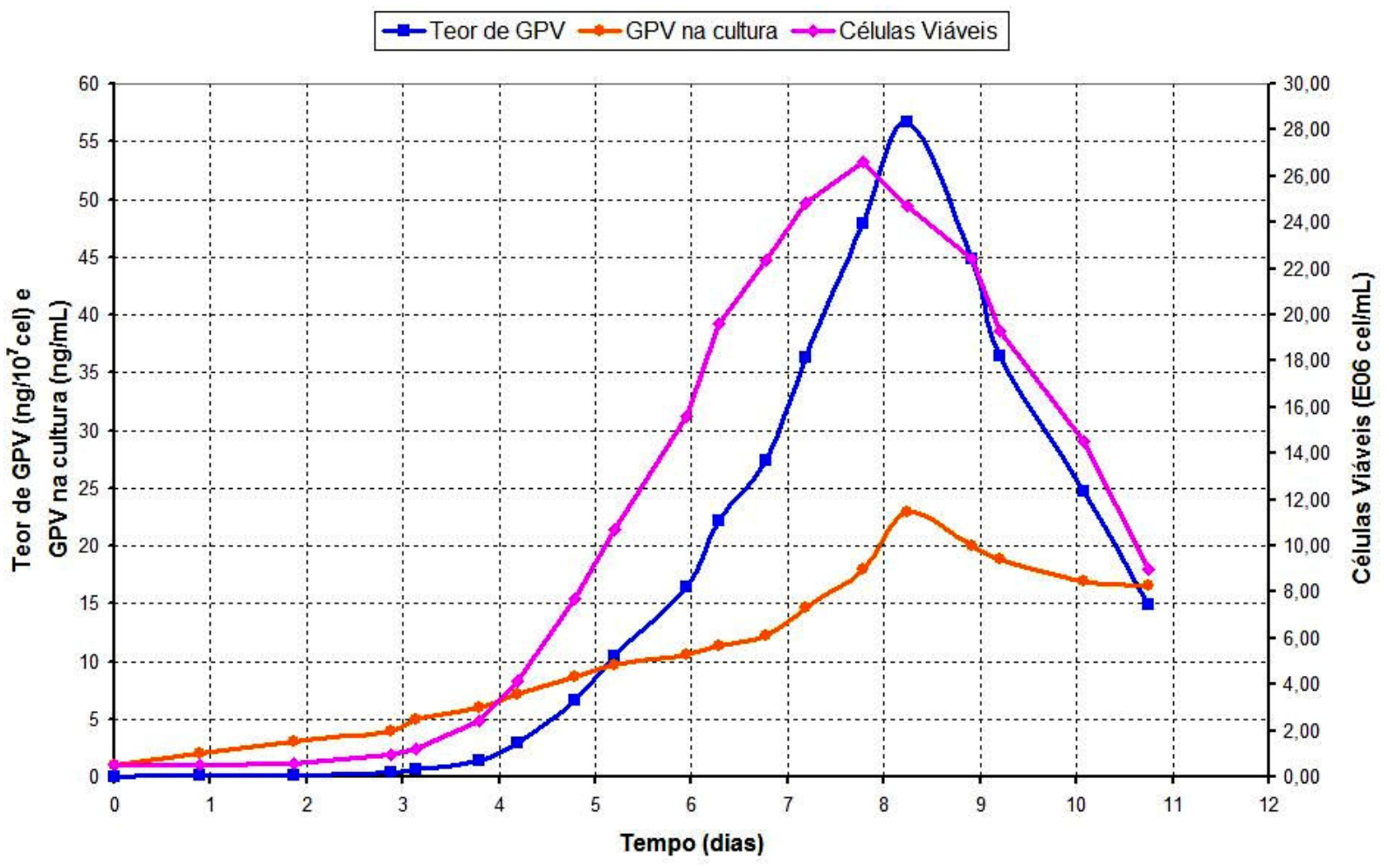

Gráfico 29 - Quantidade de GPV expressa durante o cultivo do Ensaio 4 (GPV).

\subsection{ENSAIO 5 (EGFP)}

A linhagem das células S2MtEGFP foi obtida por Mariza Gerdulo Santos (SANTOS, 2006) no Laboratório de Imunologia Viral do Instituto Butantan, conforme descrito na seção 3.1. Estas células, para expressarem a proteína EGFP, devem ser induzidas com sulfato de cobre $700 \mu \mathrm{M}$ no $3^{\circ}$ dia de cultivo (SANTOS, 2006). Como o ensaio foi executado em biorreator, onde as células sofrem uma adaptação, a indução foi feita um pouco depois do $3^{\circ}$ dia. A seta, no Gráfico 30 , indica o momento da indução.

Este ensaio foi realizado com as células na passagem 77, em meio de cultura SF900 II sem soro fetal bovino e foi controlado a $40 \%$ de OD com sobrepressão na membrana de silicone de 0,5 bar. Estas células foram descongeladas do banco de células e mantidas somente até atingirem a concentração celular necessária para inoculação do biorreator. Este ensaio transcorreu com os controles com desempenho satisfatório.

No Gráfico 30 podem ser observados todos os controles. Nota-se, mais uma vez, que os picos descendentes em OD e ação são devidos ao Método Dinâmico com a 
nova maneira desenvolvida para cálculo do $\mathrm{C}_{\text {crít, }}$ conforme seção 3.5 .5 e a completa anulação da transferência como visto na seção 3.5.4.

A concentração celular inicial foi de $0,56.10^{6} \mathrm{cel} / \mathrm{mL}$, chegando a $17,80.10^{6} \mathrm{cel} / \mathrm{mL}$ no $6^{\circ}$ dia de cultivo.

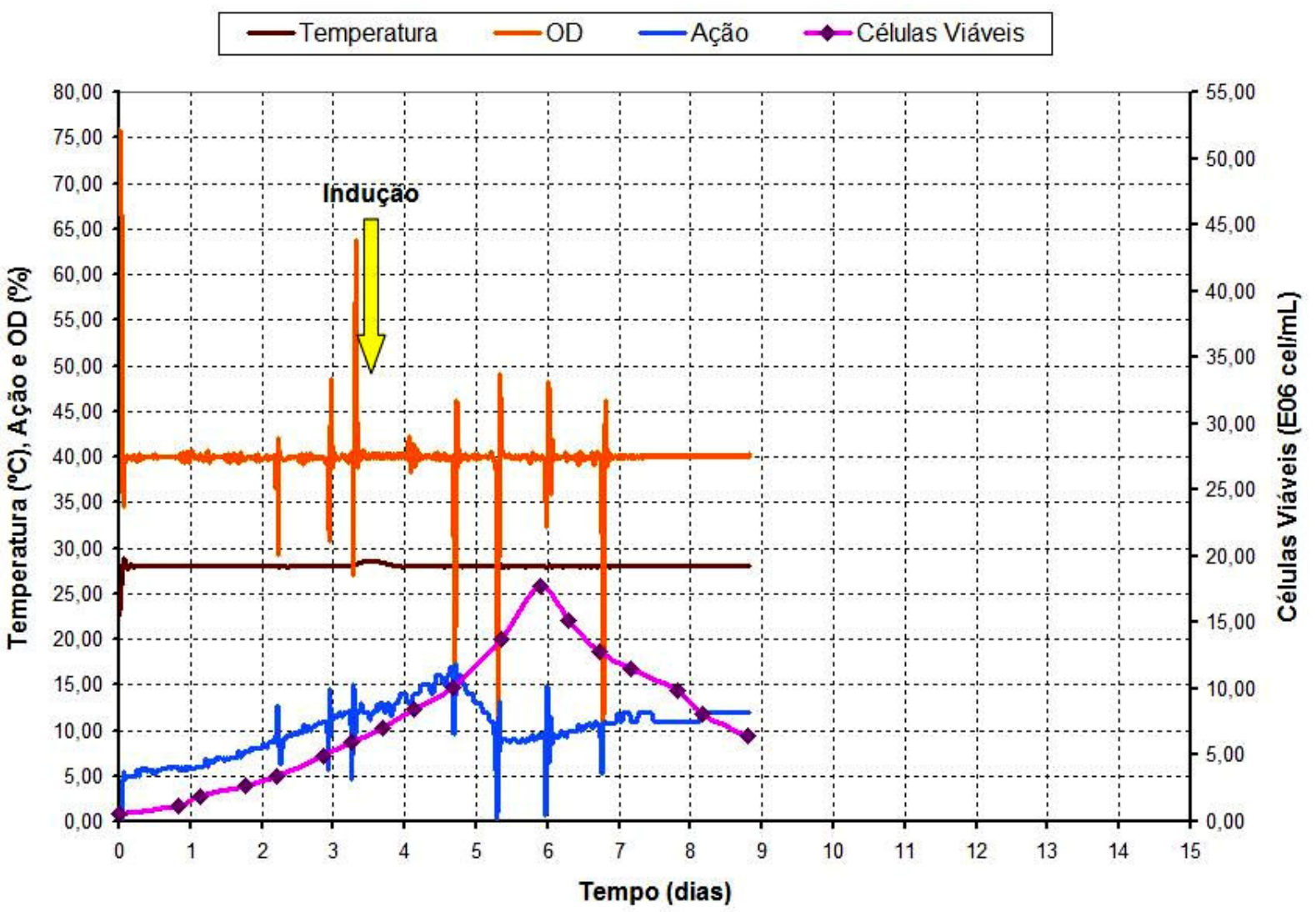

Gráfico 30 - Temperatura, OD, ação do controlador de OD e concentração de células viáveis do Ensaio 5 (EGFP) em função do tempo.

OUR, $\mathrm{k}_{\mathrm{L}}$ a e $\mathrm{Q}_{\mathrm{O} 2}$ foram medidos em oito instantes do ensaio (Apêndice $H$ ) conforme o Método Dinâmico descrito na seção 2.11 e também com a anulação completa da transferência descrita na seção 3.5.4 e apresentados na Tabela 6.

Observa-se, mais uma vez, que o $Q_{02}$ obtido pelo Método Dinâmico Tradicional foi sempre menor que o encontrado através da proposta da completa anulação da transferência. Também o $\mathrm{k}_{\mathrm{L}} \mathrm{a}$ e a OUR foram menores no Método Dinâmico Tradicional, o que confirma que, mesmo despressurizando a linha e cortando o fornecimento de oxigênio, ainda existe uma transferência de oxigênio para a cultura, vindo da cabeça do reator e também da própria membrana. 
Tabela 6 - Medidas de OUR, $\mathrm{k}_{\mathrm{L}} \mathrm{a}$ e $\mathrm{Q}_{\mathrm{O} 2}$ do Ensaio 5 (EGFP)

\begin{tabular}{cccccc}
\hline $\begin{array}{c}\mathbf{T} \\
(\mathbf{d i a s})\end{array}$ & $\begin{array}{c}\mathbf{X} \\
(\mathbf{c e l} / \mathbf{m L})\end{array}$ & $\begin{array}{c}\text { OUR } \\
\left(\mathbf{m m o l O}_{2} \cdot \mathbf{L}^{-1} \cdot \mathbf{h}^{-1}\right)\end{array}$ & $\begin{array}{c}\mathbf{k}_{\mathrm{L}} \mathbf{a} \\
\left(\mathbf{h}^{-1}\right)\end{array}$ & $\begin{array}{c}\mathbf{Q}_{\mathrm{O} 2} \\
\left(\mathbf{m o l O}_{2} \cdot \mathbf{c e l}^{-1} \cdot \mathbf{s}^{-1}\right)\end{array}$ & $\begin{array}{c}\text { Método } \\
\text { Dinâmico } \\
\text { utilizado }\end{array}$ \\
\hline 2,20 & $3,36 \cdot 10^{6}$ & 0,31 & 1,17 & $25,75 \cdot 10^{-18}$ & Método Proposto \\
2,87 & $4,90.10^{6}$ & 0,35 & 1,02 & $20,00 \cdot 10^{-18}$ & Método Proposto \\
3,25 & $6,00.10^{6}$ & 0,39 & 1,01 & $18,01 \cdot 10^{-18}$ & Método Proposto \\
& & Indução logo após a medida acima & \\
\hline 4,13 & $8,46 \cdot 10^{6}$ & 0,03 & 0,08 & $0,92 \cdot 10^{-18}$ & Tradicional \\
4,68 & $10,15 \cdot 10^{6}$ & 0,48 & 0,82 & $13,00 \cdot 10^{-18}$ & Método Proposto \\
5,34 & $13,80 \cdot 10^{6}$ & 0,16 & 0,70 & $3,20 \cdot 10^{-18}$ & Método Proposto \\
5,89 & $17,80.10^{6}$ & 0,03 & 0,07 & $0,42 \cdot 10^{-18}$ & Tradicional \\
6,73 & $12,78 \cdot 10^{6}$ & 0,19 & 0,56 & $4,22 \cdot 10^{-18}$ & Método Proposto \\
\hline
\end{tabular}

Observando-se o Gráfico 31, nota-se que os valores encontrados da OUR pelo Método Dinâmico Tradicional estão bem distantes da curva estimada da OUR pelo BFL, enquanto os valores encontrados pelo Método Dinâmico Proposto estão mais coincidentes com o estimado pelo BFL. O mesmo acontece no Gráfico $32 \mathrm{com}$ os valores do $\mathrm{Q}_{\mathrm{O} 2}$.

$\mathrm{O} \mathrm{Q}_{\mathrm{O} 2}$ atingiu seu ponto máximo no início do cultivo decaindo depois disso. Como a célula S2MtEGFP foi induzida após a $3^{\text {a }}$ medida é possível que a indução, ou melhor, a expressão da EGFP, tenha tido influência tanto na velocidade específica de respiração celular como no crescimento. Se for observada atentamente a curva de crescimento, percebe-se uma mudança na inclinação da curva após a indução. $O$ que indica que a indução alterou o comportamento da célula. 


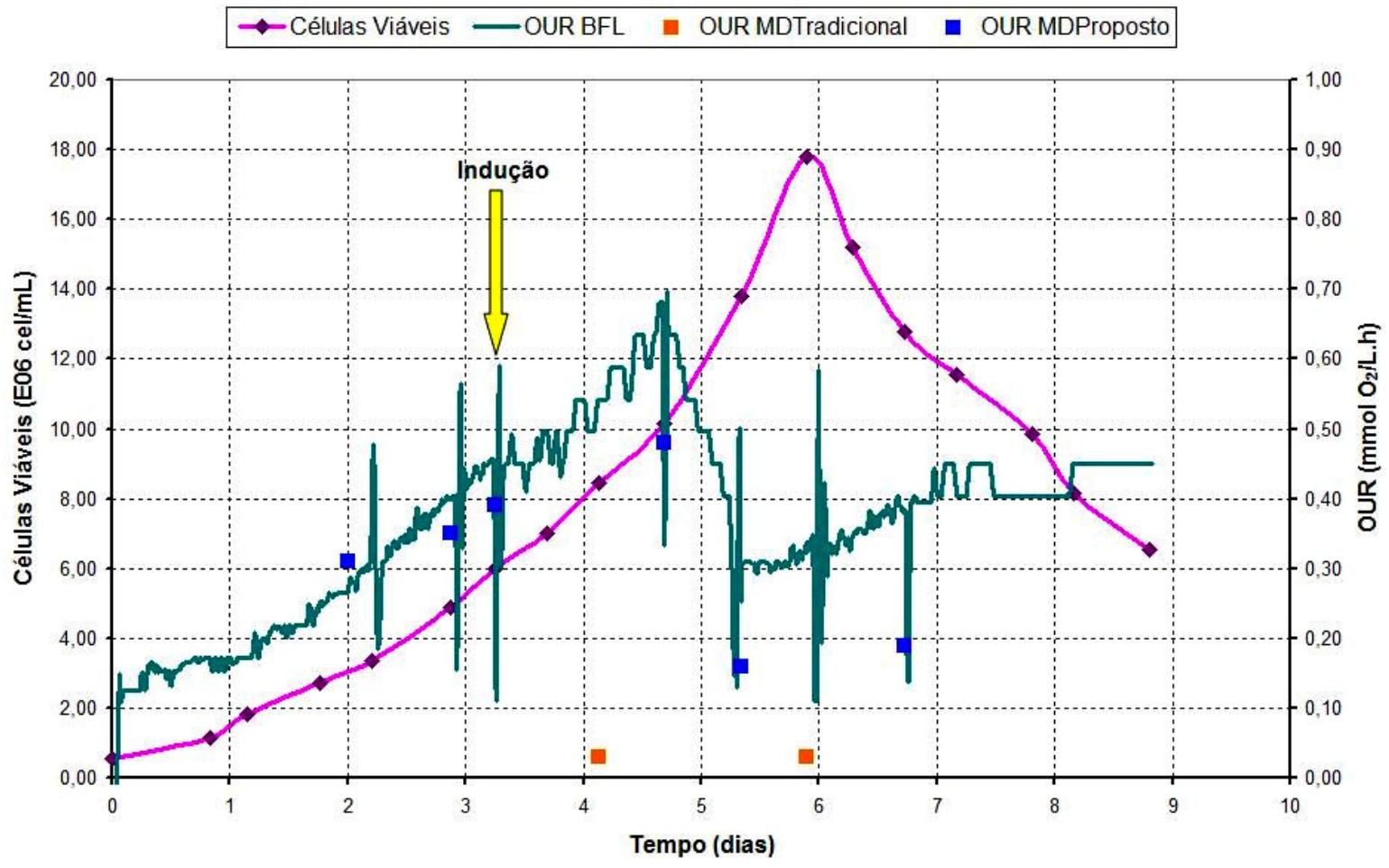

Gráfico 31 - Medidas de OUR por Método Dinâmico Tradicional e Balanço da Fase Líquida do Ensaio 5 (EGFP) em função do tempo.

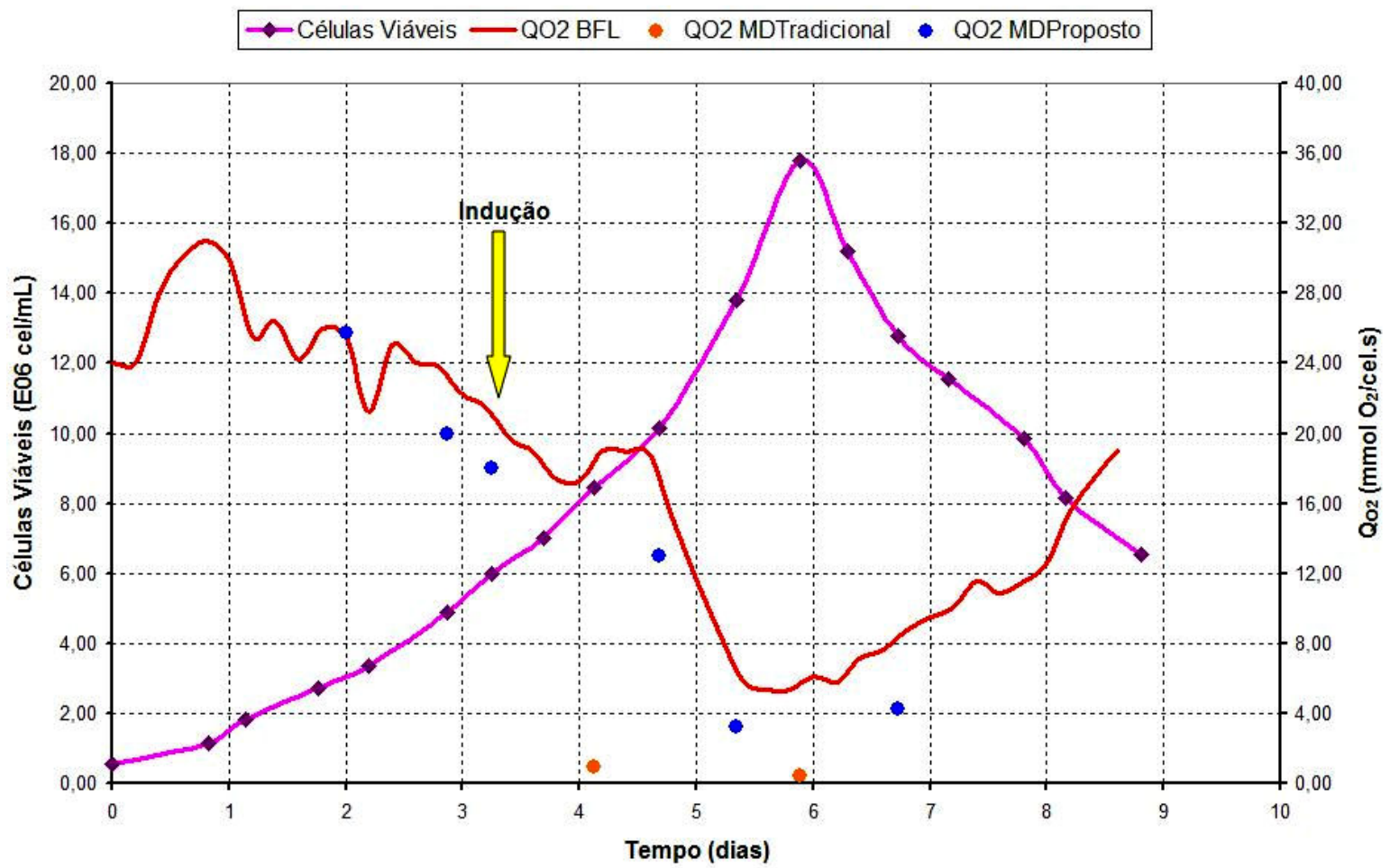

Gráfico 32 - Medidas de $\mathrm{Q}_{\mathrm{O} 2}$ por Método Dinâmico Tradicional e Balanço da Fase Líquida do Ensaio 5 (EGFP) em função do tempo.

Essa alteração também pode ser notada na curva da velocidade específica de crescimento (Gráfico 33) que tem uma mudança de comportamento após a indução, onde se observa que a máxima velocidade específica de crescimento celular $\left(\mu_{\max }\right)$ 
foi de 0,68 dia $^{-1}\left(0,028 \mathrm{~h}^{-1}\right)$ verificada até a indução, decaindo após isso para um $\mu_{\max }$ de 0,38 dia $^{-1}\left(0,016 \mathrm{~h}^{-1}\right)$. O que demonstra a mudança de comportamento comentada anteriormente. O mesmo pode ser constatado no Gráfico 34.

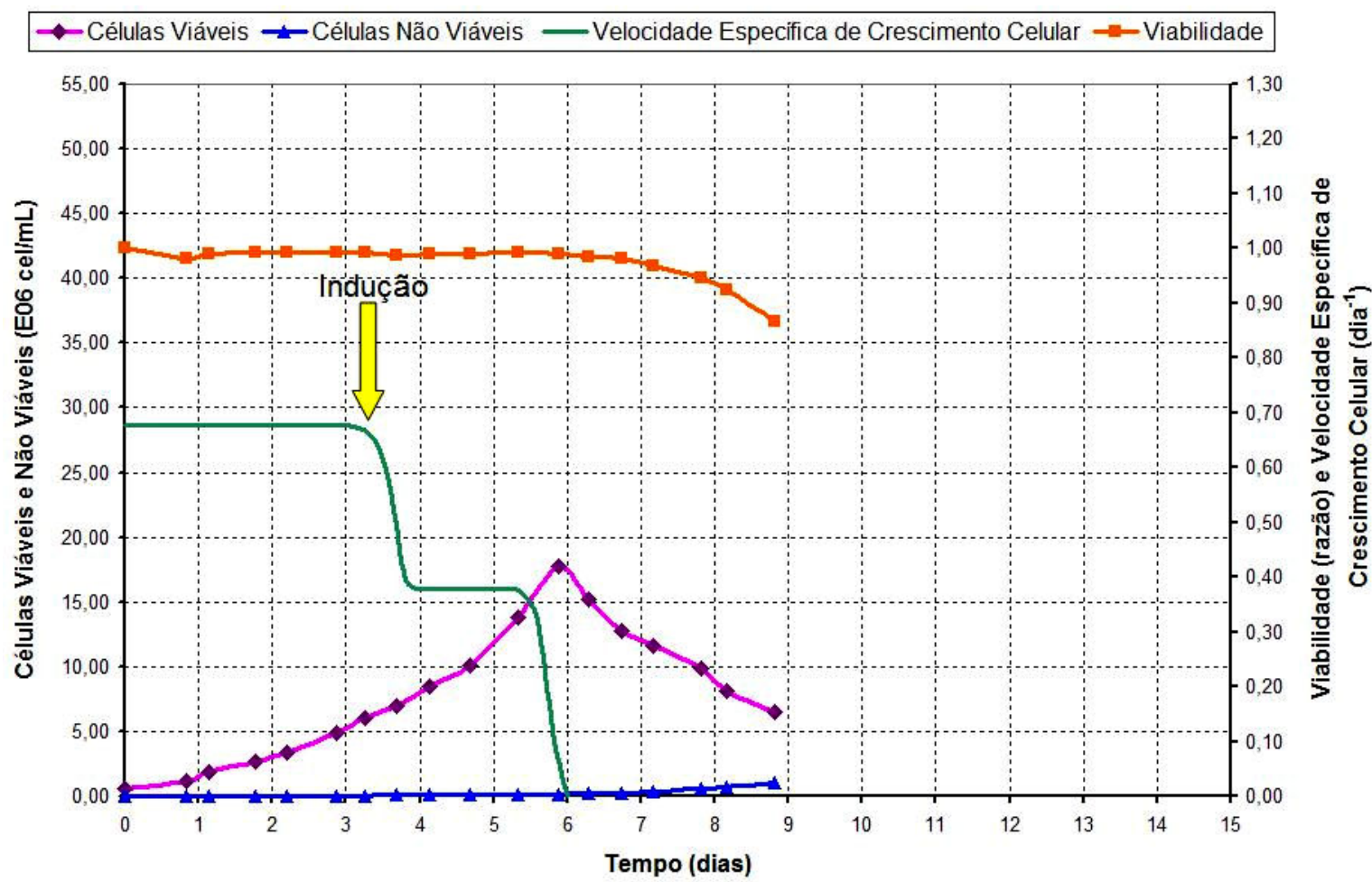

Gráfico 33 - Viabilidade celular e velocidade específica de crescimento celular do Ensaio 5 (EGFP) em função do tempo.

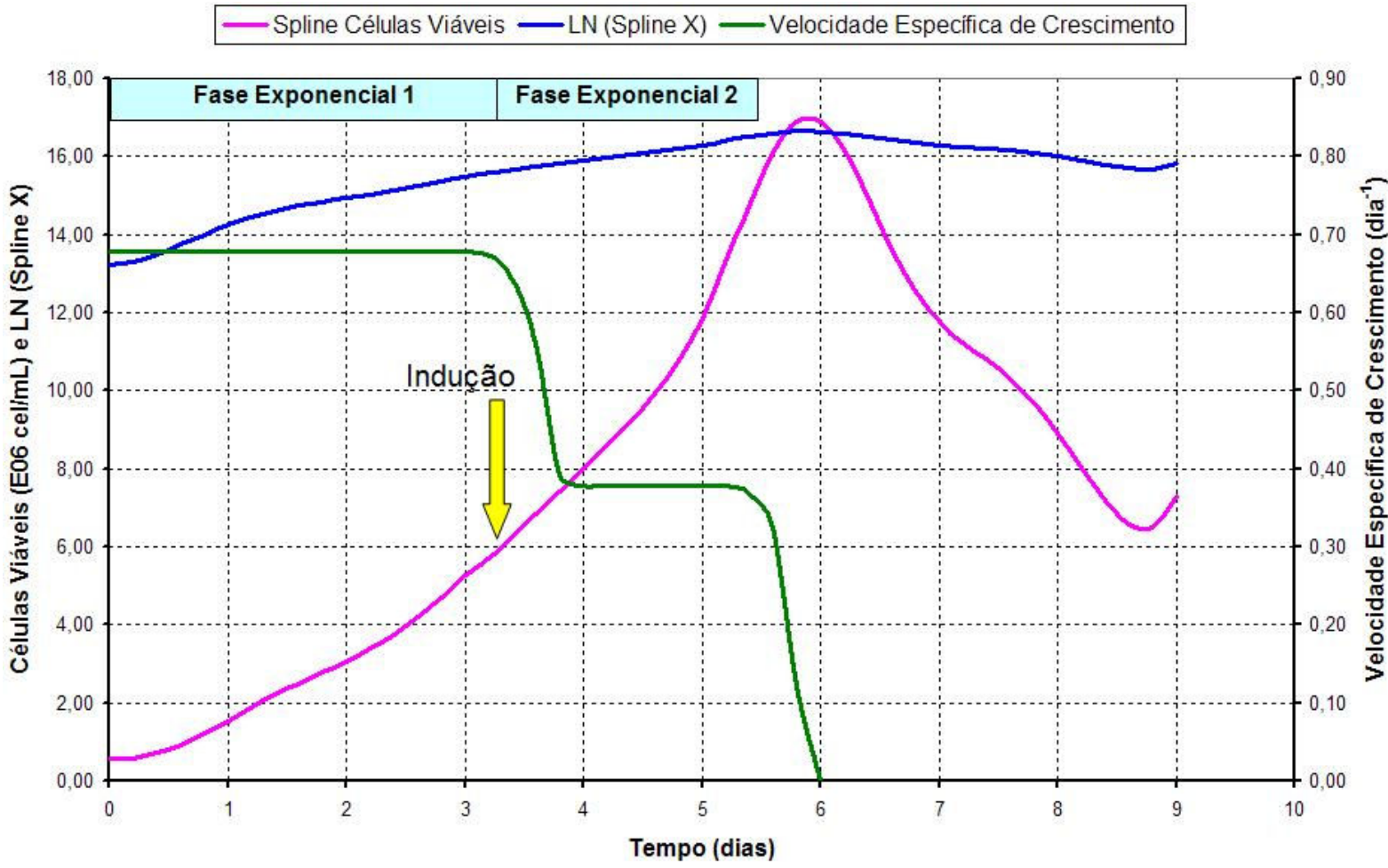

Gráfico 34 - Velocidade específica de crescimento celular do Ensaio 5 (EGFP) em função do tempo. 
No Gráfico 35, tem-se o perfil de glicose, lactato e glutamina ao longo do cultivo. A glicose foi consumida chegando a $2,72 \mathrm{~g} / \mathrm{L}$, assim como a glutamina que chegou a 1,21 g/L. O ensaio iniciou-se com $0,16 \mathrm{~g} / \mathrm{L}$ de lactato e terminou com $0,08 \mathrm{~g} / \mathrm{L}$, portanto, não foi produzido e o pouco produzido, no início do cultivo, foi consumido. Pode ser observado que após a indução com Sulfato de Cobre (após o $3^{\circ}$ dia de cultivo), houve uma alteração no consumo de glicose, glutamina e lactato.

$\mathrm{O} \mathrm{pH}$ iniciou-se em 5,99, chegando a atingir 6,44 no $7^{\circ}$ dia de cultivo e terminando em 6,16 após 9 dias de cultivo. $\mathrm{O}$ pH aumentou mais rapidamente após a indução e decaiu quando a viabilidade também começou a decair.

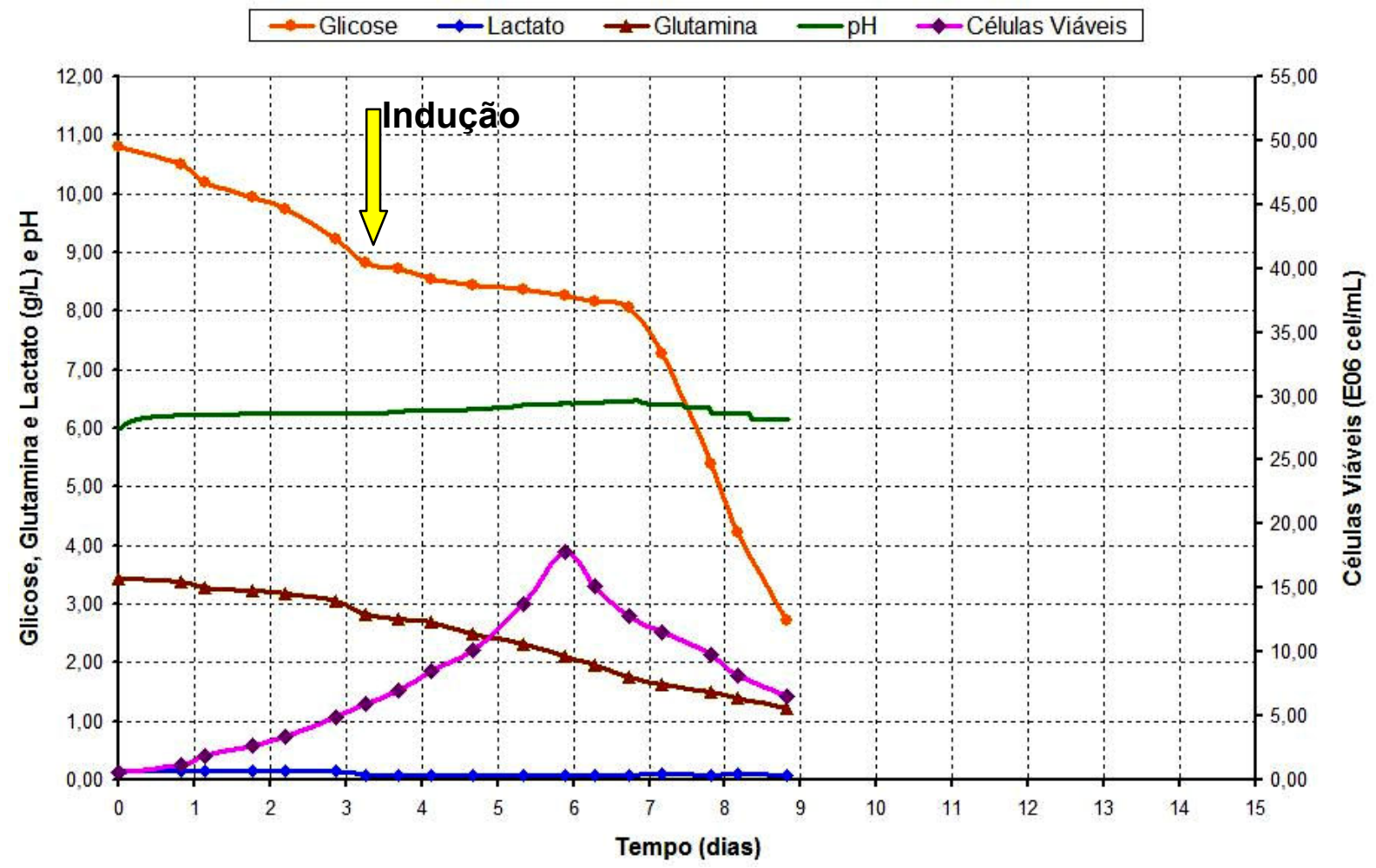

Gráfico 35 - pH e concentração de glicose, glutamina e lactato do Ensaio 5 (EGFP) em função do tempo

No Gráfico 36, têm-se os perfis das velocidades específicas de consumo de glicose, glutamina e lactato. $\mathrm{Na}$ fase de crescimento celular, as máximas velocidades específicas de consumo de glicose e glutamina foram atingidas no início do cultivo, decaindo depois disso. A máxima velocidade específica de consumo de glicose foi de $6,34.10^{-10} \mathrm{~g} /$ (cel.dia) antes da indução e de 4,44.10-11 $\mathrm{g} /$ (cel.dia) após a indução. Pode ser percebida, assim, a alteração na velocidade de consumo de glicose e glutamina após a indução. 


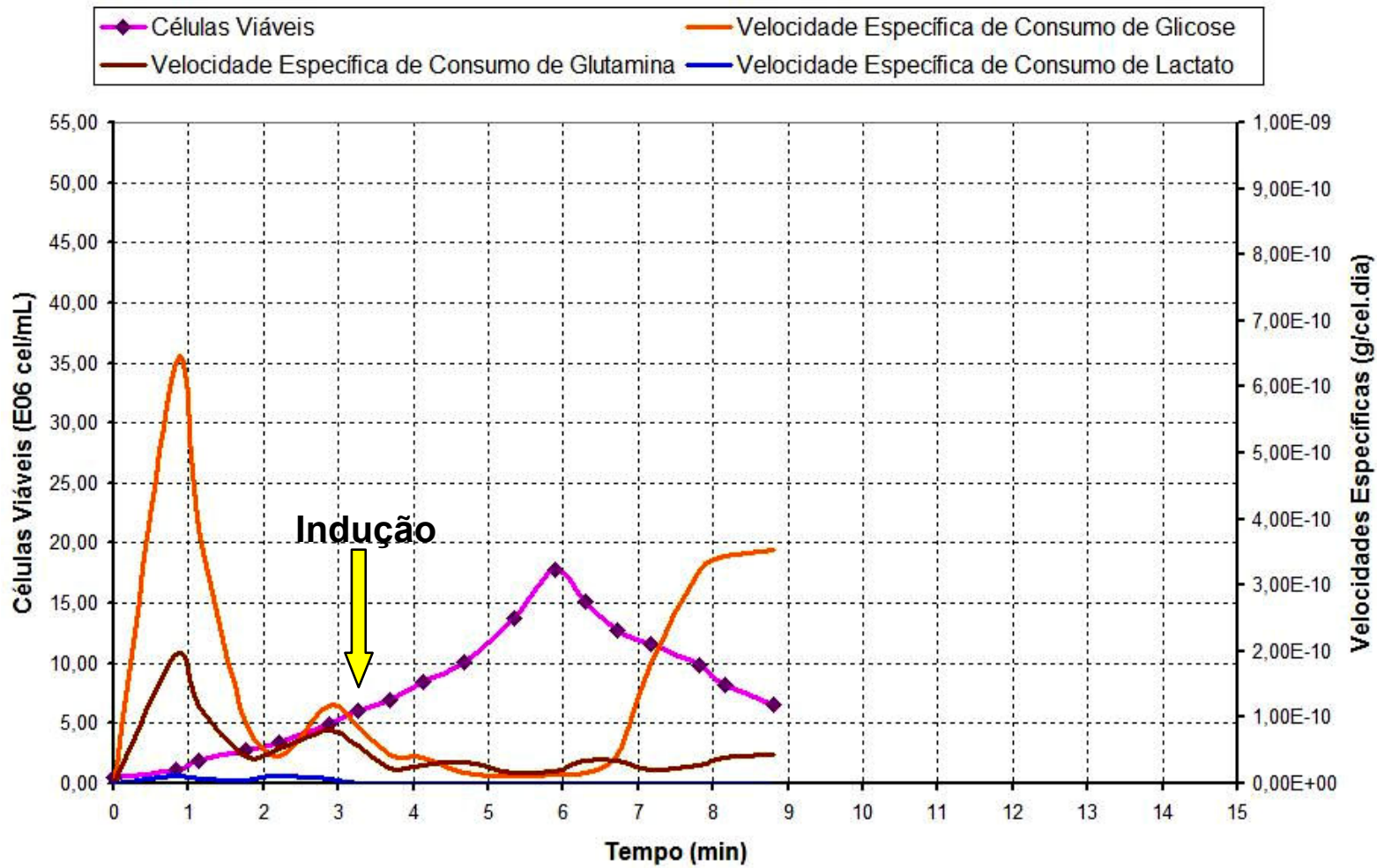

Gráfico 36 - Velocidades Específicas de Consumo e Produção de Substratos do Ensaio 5 (EGFP) em função do tempo

\subsection{1 $\mathrm{C}_{\text {crítico }}$}

O valor de $\mathrm{C}_{\text {crit }}$ calculado está em torno de $5 \%$ da saturação com ar conforme mostra

- Gráfico 37. As medidas foram feitas em vários pontos diferentes do cultivo (Apêndice $\mathrm{H}$ ) e em todas às vezes a curva mudou sua inclinação praticamente no mesmo ponto.

Nota-se ainda que o valor do $\mathrm{C}_{\text {crit }}$ é menor nesta linhagem que na linhagem anterior e na S2 selvagem. 


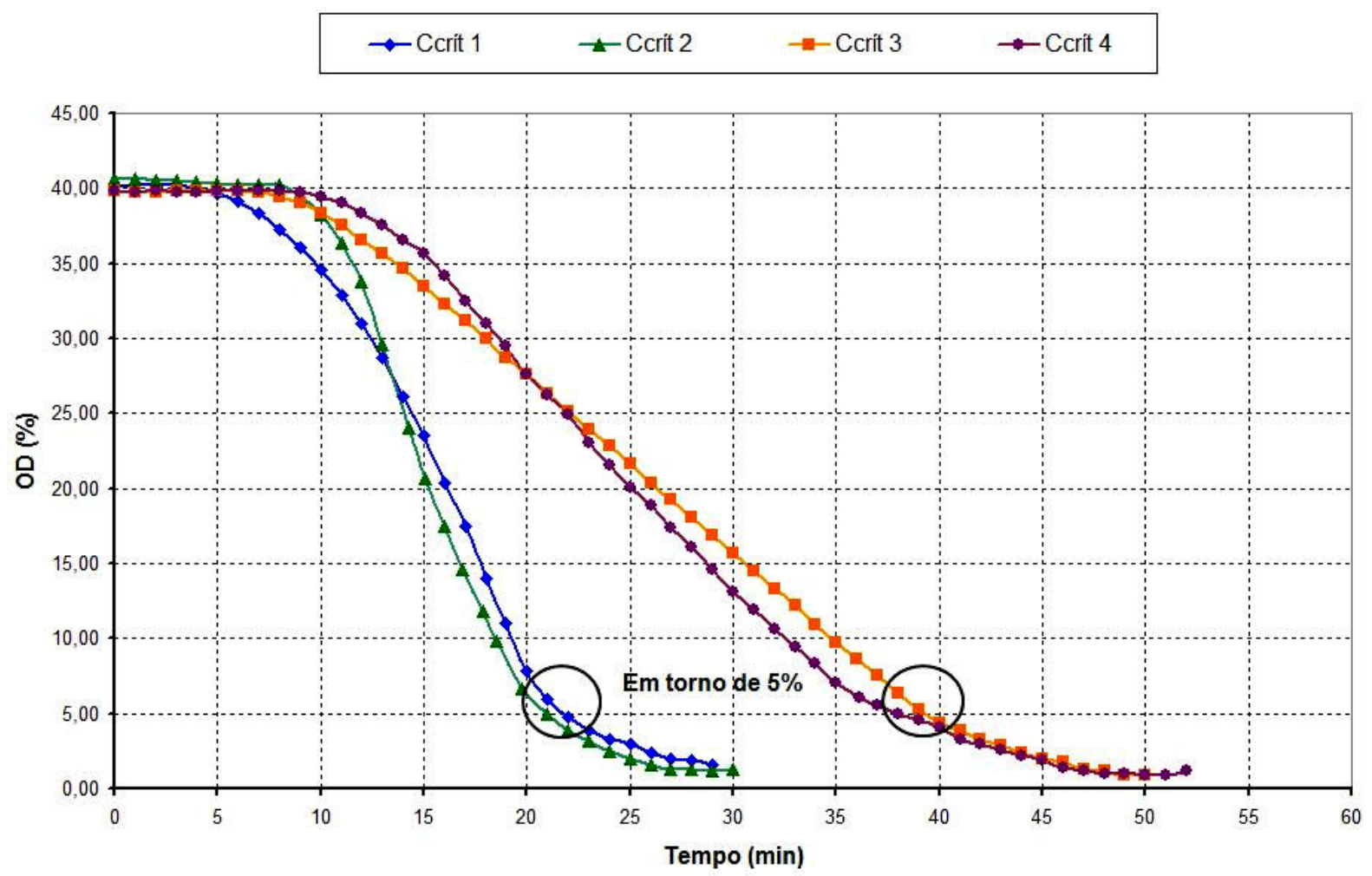

Gráfico 37 - Cálculo do $\mathrm{C}_{\text {critico }}$ em quatro diferentes pontos do cultivo no Ensaio 5 (EGFP) sendo: $\mathrm{C}_{\text {crit }}$ 1 em $6.10^{6} \mathrm{cel} / \mathrm{mL} ; C_{\text {crit }} 2$ em $10,15.10^{6} \mathrm{cel} / \mathrm{mL} ; \mathrm{C}_{\text {crit }} 3 \mathrm{em} 13,8.10^{6} \mathrm{cel} / \mathrm{mL}$ e $C_{\text {crit }} 4 \mathrm{em} 12,78.10^{6}$ $\mathrm{cel} / \mathrm{mL}$.

\subsubsection{Expressão de EGFP}

Como citado na seção 3.4.4, as análise das amostras de EGFP durante o cultivo foram feitas no citômetro de fluxo (FACS - Fluorescence Activated cell Sorter) sob supervisão do Dr. Jorge Mário C. Ferreira Jr. do Laboratório de Imunoquímica do Instituto Butantan.

Após a indução com sulfato de cobre $(700 \mu \mathrm{M})$, as células que expressam a EGFP de forma basal passam a expressar mais proteína, que, após estimulação, é fluorescente. M1 corresponde à população de células fluorescentes, assim a população de células localizada no M1 apontada no histograma da Figura 24 corresponde a $87 \%$ da população total analisada e 68 é a intensidade média de fluorescência das células representadas em M1 detectada pelo filtro de $530 \mathrm{~nm}$ (FL1). Estes valores são calculados automaticamente pelo citômetro de fluxo. 


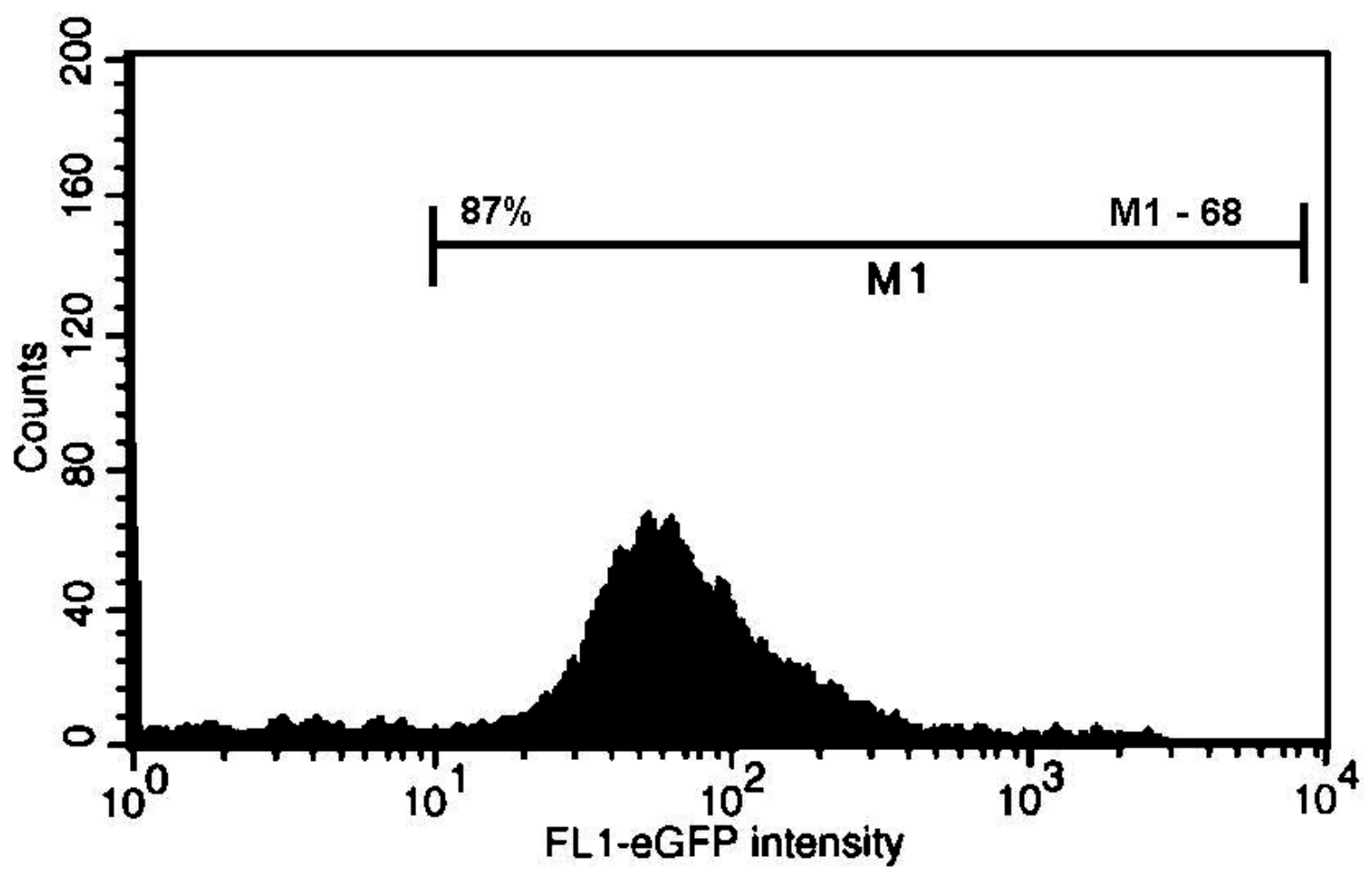

Figura 24 - Histograma da análise em citômetro de fluxo em seu ponto máximo

No Gráfico 38 tem-se a porcentagem de células fluorescentes durante o ensaio e também a intensidade média de fluorescência das células.

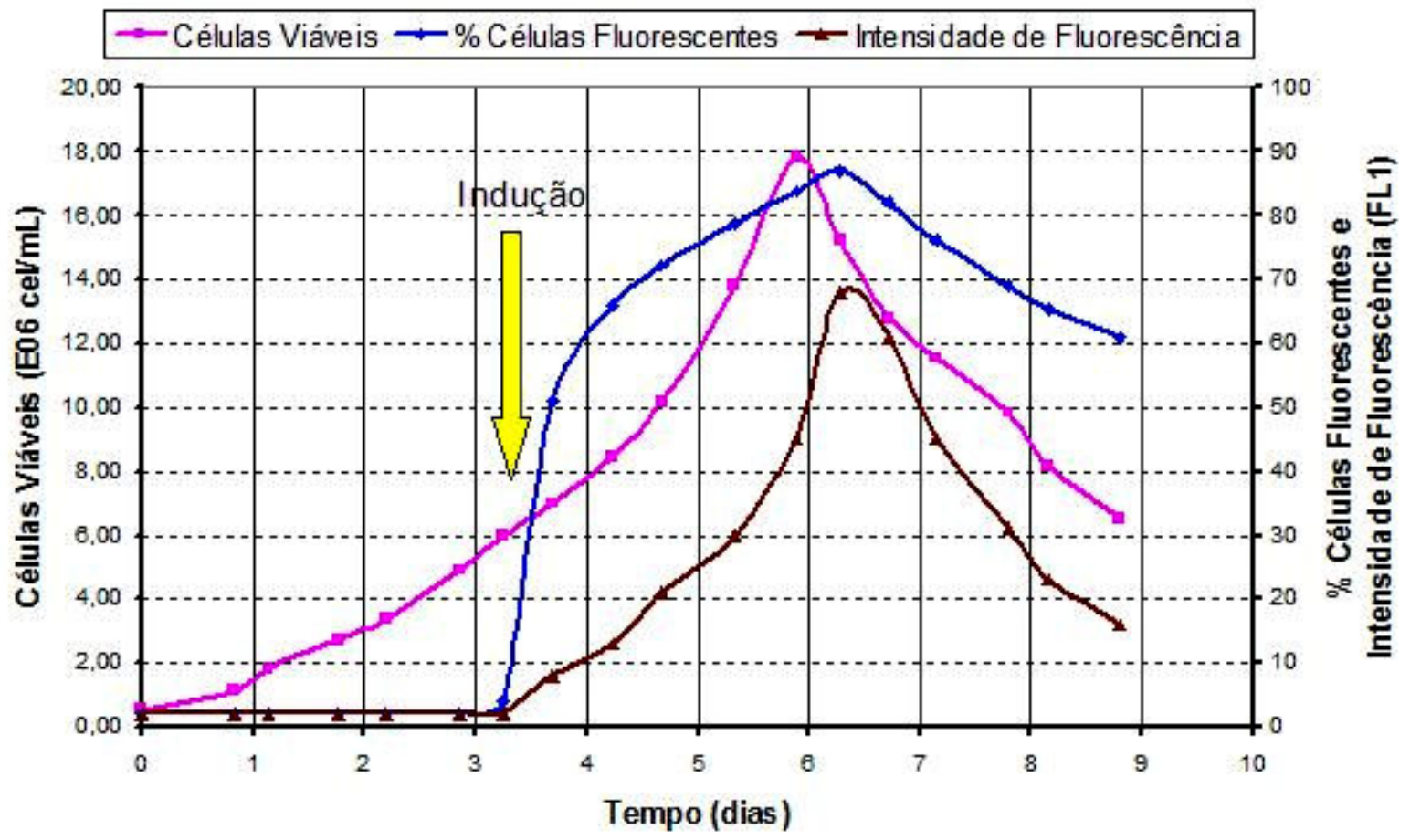

Gráfico 38 - Células Viáveis, Intensidade e Porcentagem de células florescentes ao longo do cultivo no Ensaio 5 (EGFP). 
Os resultados alcançados durante o ensaio, assim como a porcentagem de células fluorescentes e a intensidade média de fluorescência das células são equivalentes aos alcançados por SANTOS (2006) em ensaios com Schott. Em reator seria de se esperar que houvesse um aumento da concentração celular e consequentemente da intensidade de fluorescência total das células, pois em reator tem-se oxigênio e nutrientes mais abundantemente do que em experimentos realizados em frascos Schotts. Porém, o que se obteve foram resultados muito semelhantes.

O que se pode entender é que: primeiramente, como pode ser verificado no estudo da atividade respiratória, a velocidade de respiração das células S2MtEGFP é menor que as células S2AcGPV2, e como nos ensaios em Schott todos os dias eram coletadas amostras, renovando-se o ar no interior do Schott, não deve ter havido em nenhum instante falta de oxigênio. Ou seja, a velocidade de respiração das células cultivadas no Schott não foi afetada por uma eventual falta de oxigenação. E em segundo lugar, como pode ser observado no estudo da cinética dos substratos, a glicose e também a glutamina não chegaram a ser esgotadas. Portanto, apenas a escala (biorreator ou Schott) foi diferente, mas porcentualmente houve o mesmo resultado.

Outro ponto a ser discutido é que como essas células que foram cultivadas em biorreator vieram do estoque congelado, talvez se devesse ter feito, após o descongelamento, uma nova seleção com higromicina. Talvez, com essa nova seleção, se obtivessem mais células que expressam a EGFP.

\subsection{ENSAIO 6 (HBsAg)}

A linhagem das células S2AcHBsAgHy foi obtida pela Dra.Soraia Attie Calil Jorge no Laboratório de Imunologia Viral do Instituto Butantan, conforme descrito na seção 3.1. Esta célula expressa HBsAg constitutivamente, porém foi adicionado, após o $5^{\circ}$ dia de cultivo, butirato de sódio $5 \mathrm{mM}$ para acentuar a expressão. A seta no Gráfico 39 refere-se ao momento de adição do butirato de sódio.

Este ensaio foi realizado com as células na passagem 12, em meio de cultura SF900 II sem soro fetal bovino e foi controlado a $40 \%$ de OD com sobrepressão na 
membrana de silicone de 0,5 bar. Este ensaio transcorreu com os controles com desempenho satisfatório.

No Gráfico 39 podem ser observados todos os controles. Nota-se, mais uma vez, que os picos descendentes em OD e ação são devidos ao Método Dinâmico com a nova maneira desenvolvida para cálculo do $\mathrm{C}_{\text {crit, }}$ conforme seção 3.5 .5 e completa anulação da transferência de oxigênio conforme seção 3.5.4.

A concentração celular inicial foi de $0,42 \cdot 10^{6} \mathrm{cel} / \mathrm{mL}$, chegando a $16,60 \cdot 10^{6} \mathrm{cel} / \mathrm{mL}$ no $11^{\circ}$ dia de cultivo.

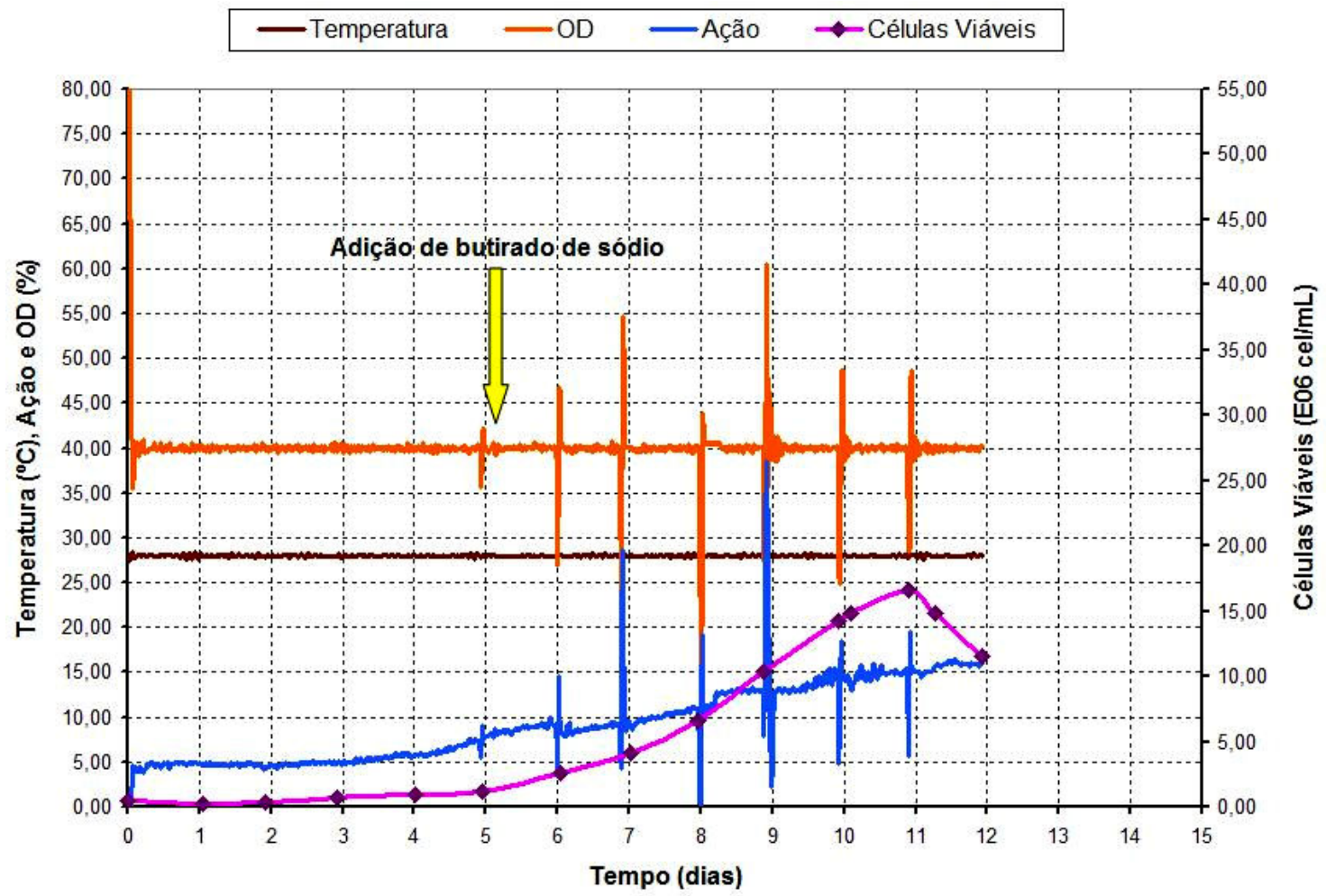

Gráfico 39 - Temperatura, OD, ação do controlador de OD e concentração de células viáveis do Ensaio 6 (HBsAg) em função do tempo.

OUR, k $\mathrm{L}_{\mathrm{L}}$ e $\mathrm{Q}_{\mathrm{O} 2}$ foram medidos em oito instantes do ensaio (Apêndice I) conforme o Método Dinâmico descrito na seção 2.11 e também com a anulação completa da transferência descrita na seção 3.5.4 e apresentados na Tabela 7. Sendo que o $\mathrm{Q}_{\mathrm{O} 2}$ máximo obtido foi na fase exponencial.

Observa-se, mais uma vez, que o Qo2 obtido pelo Método Dinâmico Tradicional foi sempre menor que o encontrado através da proposta da completa anulação da transferência. Também o $\mathrm{k} \mathrm{L} a$ e a OUR foram menores no Método Dinâmico Tradicional, o que confirma que, mesmo despressurizando a linha e cortando o 
fornecimento de oxigênio, ainda existe uma transferência de oxigênio para a cultura, vindo da cabeça do reator e também da própria membrana.

Tabela 7 - Medidas de OUR, $\mathrm{k}_{\mathrm{L}}$ a e Q $\mathrm{O} 2$ do Ensaio 6 (HBsAg)

\begin{tabular}{|c|c|c|c|c|c|}
\hline $\begin{array}{c}\mathrm{T} \\
\text { (dias) }\end{array}$ & $\begin{array}{c}X \\
(\text { cel/mL) }\end{array}$ & $\begin{array}{c}\text { OUR } \\
\left(\mathrm{mmolO}_{2} \cdot \mathrm{L}^{-1} \cdot \mathrm{h}^{-1}\right)\end{array}$ & $\begin{array}{l}\mathbf{k}_{\mathrm{L}} \mathbf{a} \\
\left(\mathbf{h}^{-1}\right)\end{array}$ & $\begin{array}{c}Q_{02} \\
\left(\mathrm{molO}_{2} \cdot \mathrm{cel}^{-1} \cdot \mathrm{s}^{-1}\right)\end{array}$ & $\begin{array}{l}\text { Método } \\
\text { Dinâmico } \\
\text { utilizado }\end{array}$ \\
\hline 4,95 & $1,20.10^{6}$ & 0,08 & 0,41 & $17,77.10^{-18}$ & Tradicional \\
\hline 6,03 & $2,60 \cdot 10^{6}$ & 0,10 & 0,38 & $10,89 \cdot 10^{-18}$ & Tradicional \\
\hline 7,03 & $4,10.10^{6}$ & 0,50 & 1,86 & $33,63 \cdot 10^{-18}$ & Método Proposto \\
\hline 7,97 & $6,60 \cdot 10^{6}$ & 0,17 & 0,48 & $6,94 \cdot 10^{-18}$ & Tradicional \\
\hline 8,87 & $10,40 \cdot 10^{6}$ & 0,71 & 1,68 & $18,91 \cdot 10^{-18}$ & Método Proposto \\
\hline 9,91 & $14,20.10^{6}$ & 0,21 & 0,42 & $4,12 \cdot 10^{-18}$ & Tradicional \\
\hline 10,89 & $16,60 \cdot 10^{6}$ & 0,83 & 1,55 & $13,86 \cdot 10^{-18}$ & Método Proposto \\
\hline
\end{tabular}

Observando-se o Gráfico 40, nota-se que os valores encontrados da OUR pelo Método Dinâmico Tradicional estão bem distantes da curva estimada da OUR pelo BFL, enquanto os valores encontrados pelo Método Dinâmico Proposto estão mais coincidentes com o estimado pelo BFL. O mesmo acontece no Gráfico 41 com os valores do Qo2. 


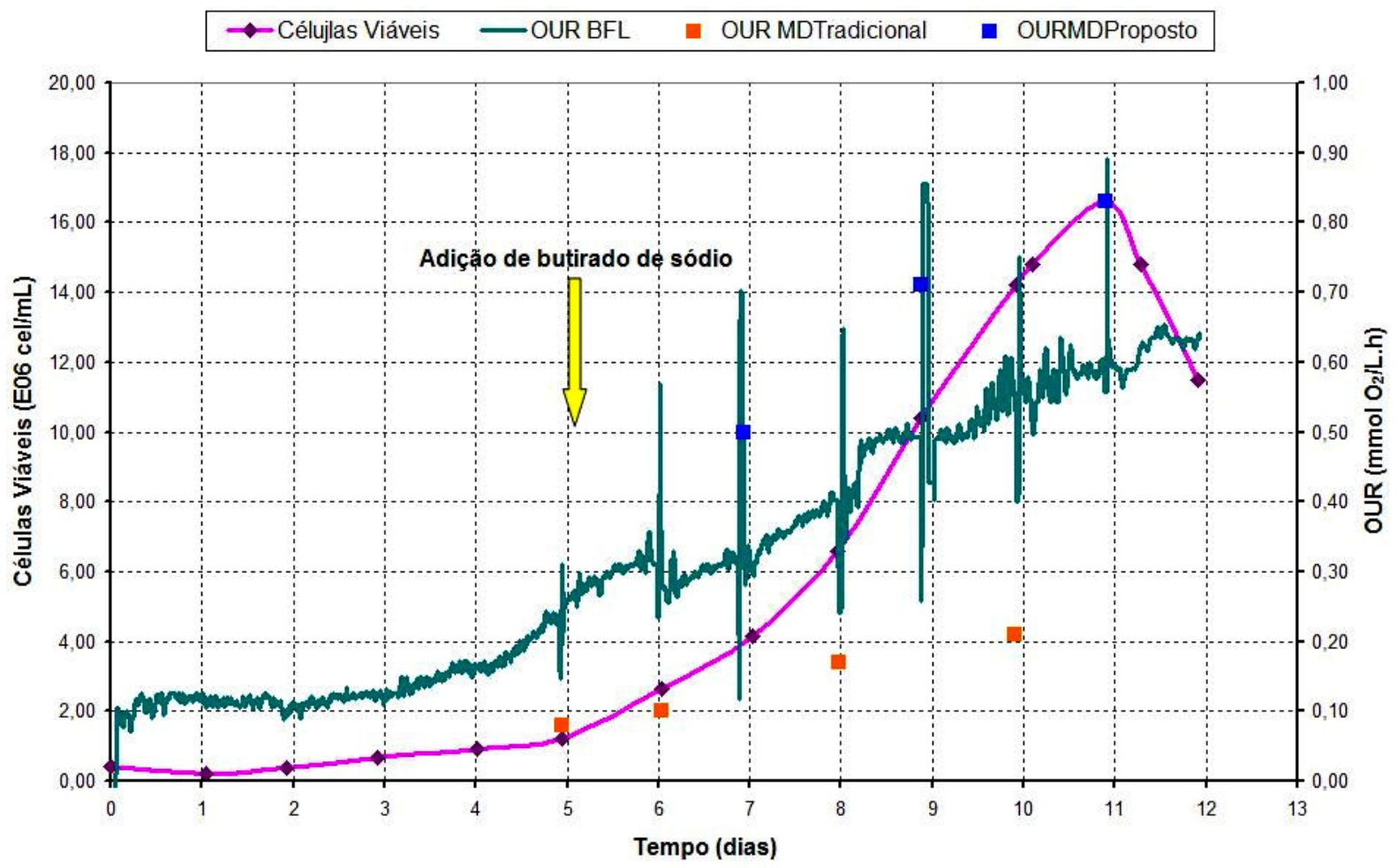

Gráfico 40 - Medidas de OUR por Método Dinâmico Tradicional e Balanço da Fase Líquida do Ensaio 6 (HBsAg) em função do tempo.

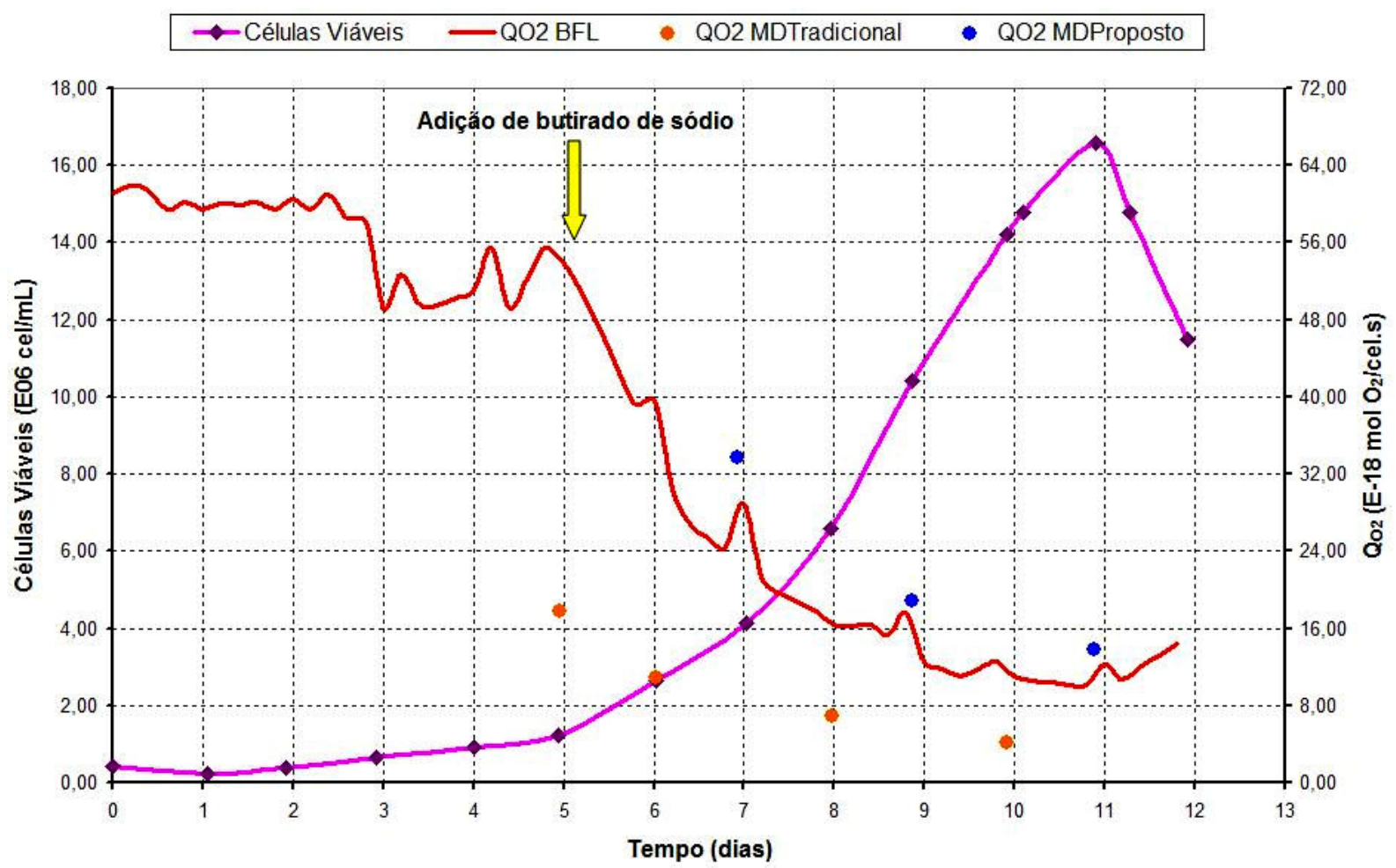

Gráfico 41 - Medidas de $\mathrm{Q}_{\mathrm{O} 2}$ por Método Dinâmico Tradicional e Balanço da Fase Líquida do Ensaio 6(HBsAg) em função do tempo. 
No Gráfico 42, observa-se que a máxima velocidade específica de crescimento celular $\left(\mu_{\max }\right)$ foi de $0,64 \mathrm{dia}^{-1}\left(0,027 \mathrm{~h}^{-1}\right)$ verificado até o $3^{\circ}$ dia de cultivo, decaindo após isso, devido a adição do butirato de sódio, para 0,48 dia ${ }^{-1}\left(0,020 \mathrm{~h}^{-1}\right)$.

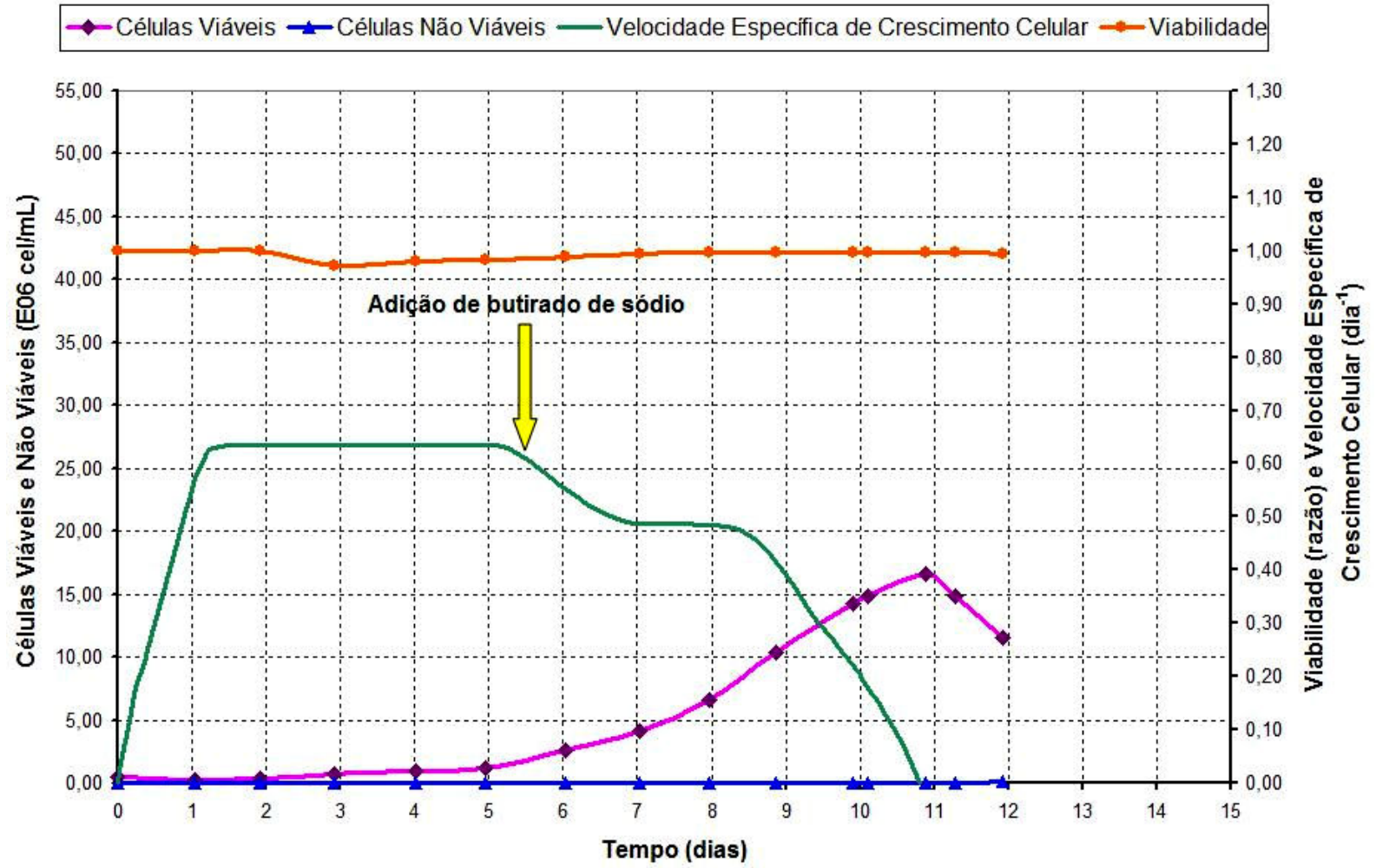

Gráfico 42 - Viabilidade celular e velocidade específica de crescimento celular do Ensaio 6 (HBsAg) em função do tempo.

O butirato de sódio promove a descondensação do DNA levando a um aumento generalizado da expressão gênica, devido ao maior acesso dos fatores de transcrição às fitas de DNA e influenciando no crescimento celular (CHEN et al. 2002).

No Gráfico 43, observa-se o crescimento celular por spline, o logaritmo neperiano (In) do crescimento celular e também a velocidade específica de crescimento celular, onde se nota as duas fases exponenciais distintas devido a adição do butirato de sódio. 


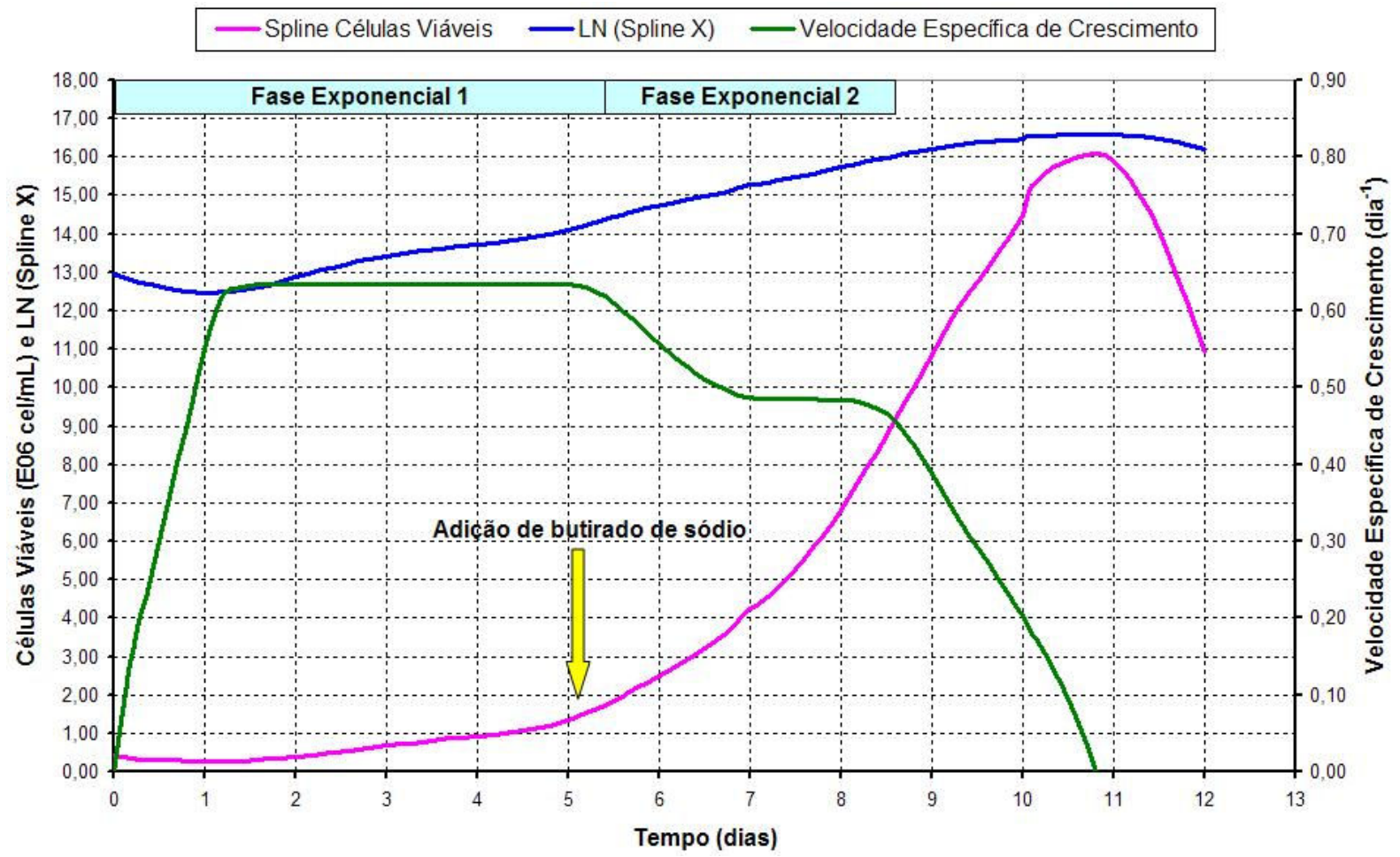

Gráfico 43 - Velocidade específica de crescimento celular do Ensaio 6 (HBsAg) em função do tempo.

No Gráfico 44, tem-se o perfil de glicose, lactato e glutamina ao longo do cultivo. A glicose foi consumida chegando a $2,63 \mathrm{~g} / \mathrm{L}$, assim como a glutamina que chegou a $1,12 \mathrm{~g} / \mathrm{L}$. O ensaio iniciou-se com $0,05 \mathrm{~g} / \mathrm{L}$ de lactato e terminou com $0,02 \mathrm{~g} / \mathrm{L}$, portanto, não foi produzido e sim consumido.

$\mathrm{O}$ pH iniciou-se em 6,05 atingindo 6,98 após 12 dias de cultivo.

No Gráfico 45, têm-se os perfis das velocidades específicas de consumo de glicose, glutamina e lactato. As máximas velocidades específicas de consumo de glicose e glutamina foram atingidas no início do cultivo, decaindo depois disso. A máxima velocidade específica de consumo de glicose foi $9,17.10^{-10} \mathrm{~g} /$ (cel.dia) durante a primeira fase exponencial e decaindo depois da adição de butirato de sódio para $2,05.10^{-10} \mathrm{~g} /$ (cel.dia).

Este ensaio foi encerrado logo após o início da queda da viabilidade para que fosse possível guardar o caldo fermentado para posterior análises e também para purificação da HBsAg. 


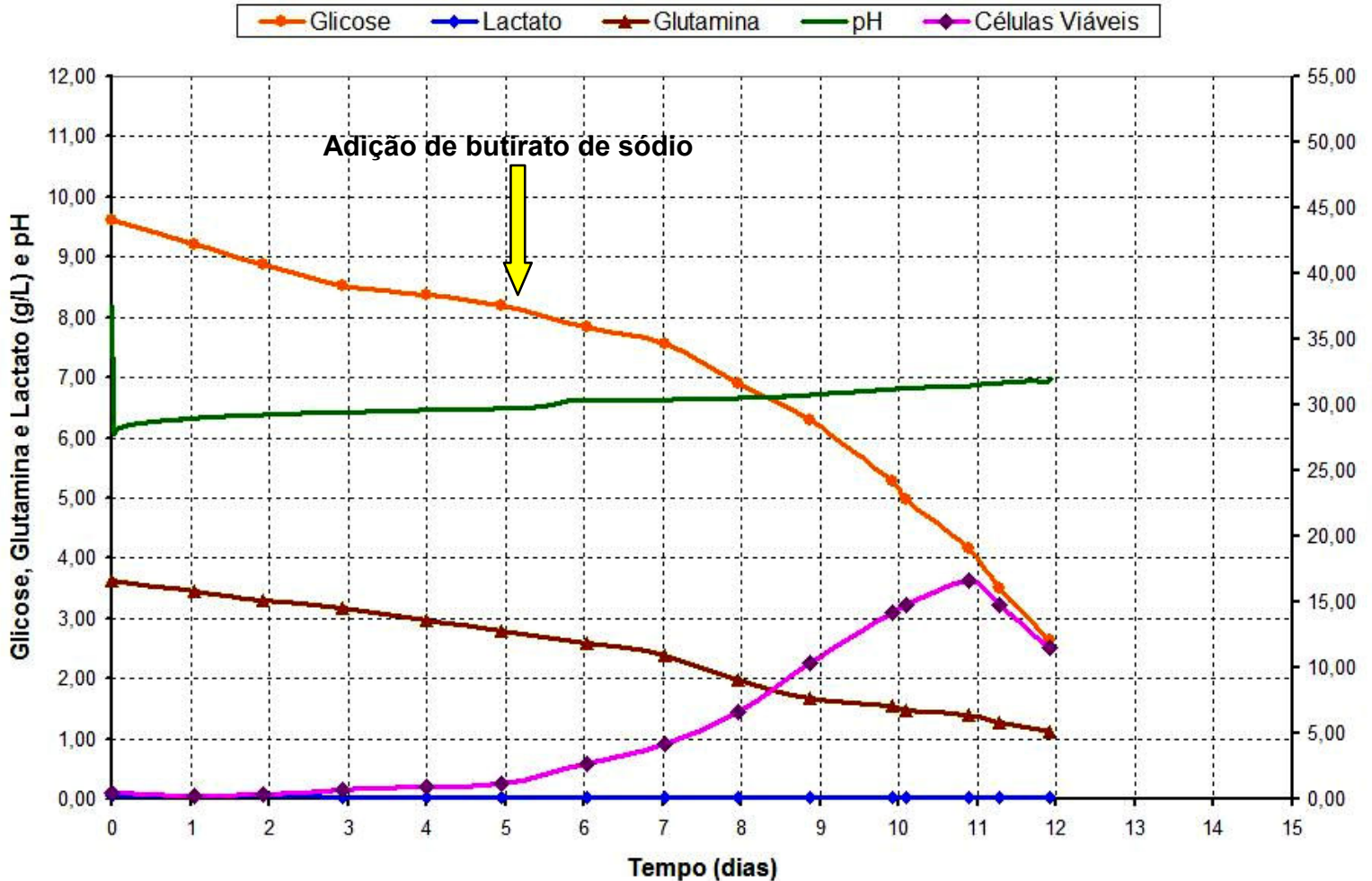

Gráfico 44 - pH, concentração de glicose, glutamina e lactato do Ensaio 6 (HBsAg) em função do tempo

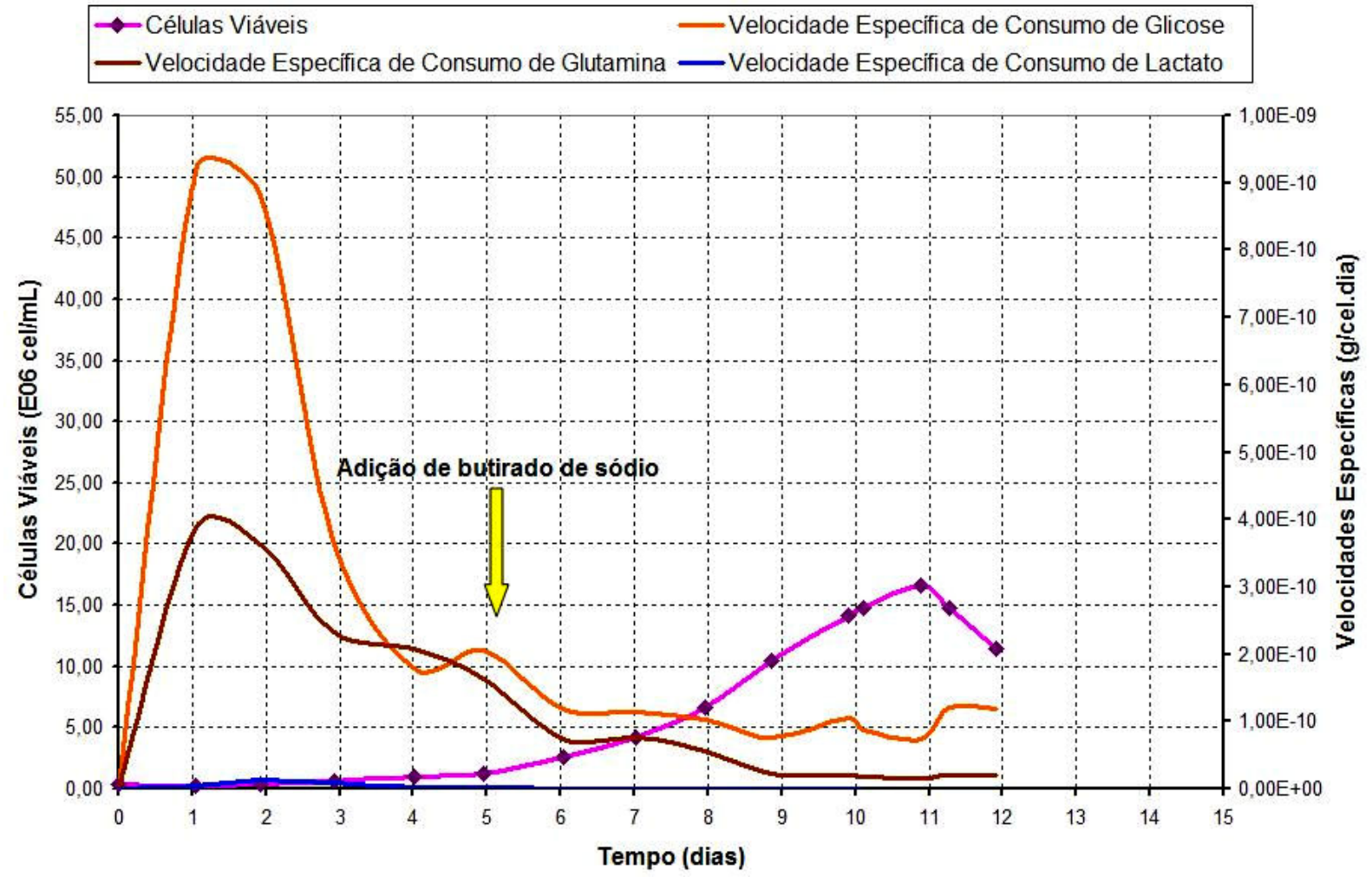

Gráfico 45 - Velocidades Específicas de Consumo de glicose, glutamina e lactato do Ensaio 6 (HBsAg) em função do tempo 


\subsection{1 $\mathrm{C}_{\text {crítico }}$}

O valor de $C_{\text {crit }}$ calculado está em torno de $12 \%$ da saturação com ar conforme mostra o Gráfico 46. As medidas foram feitas em vários pontos diferentes do cultivo (Apêndice I) e em todas às vezes a curva mudou sua inclinação praticamente no mesmo ponto.

As medidas de $\mathrm{C}_{\text {crit }}$ numeradas como 1, 2 e 3 foram executadas durante o Método Dinâmico Proposto e as numeradas como 4 e 5 foram executadas durante o Método Dinâmico Tradicional. Pode-se observar que, novamente, o valor de $\mathrm{C}_{\text {crít }}$ independe do modo de execução do Método Dinâmico.

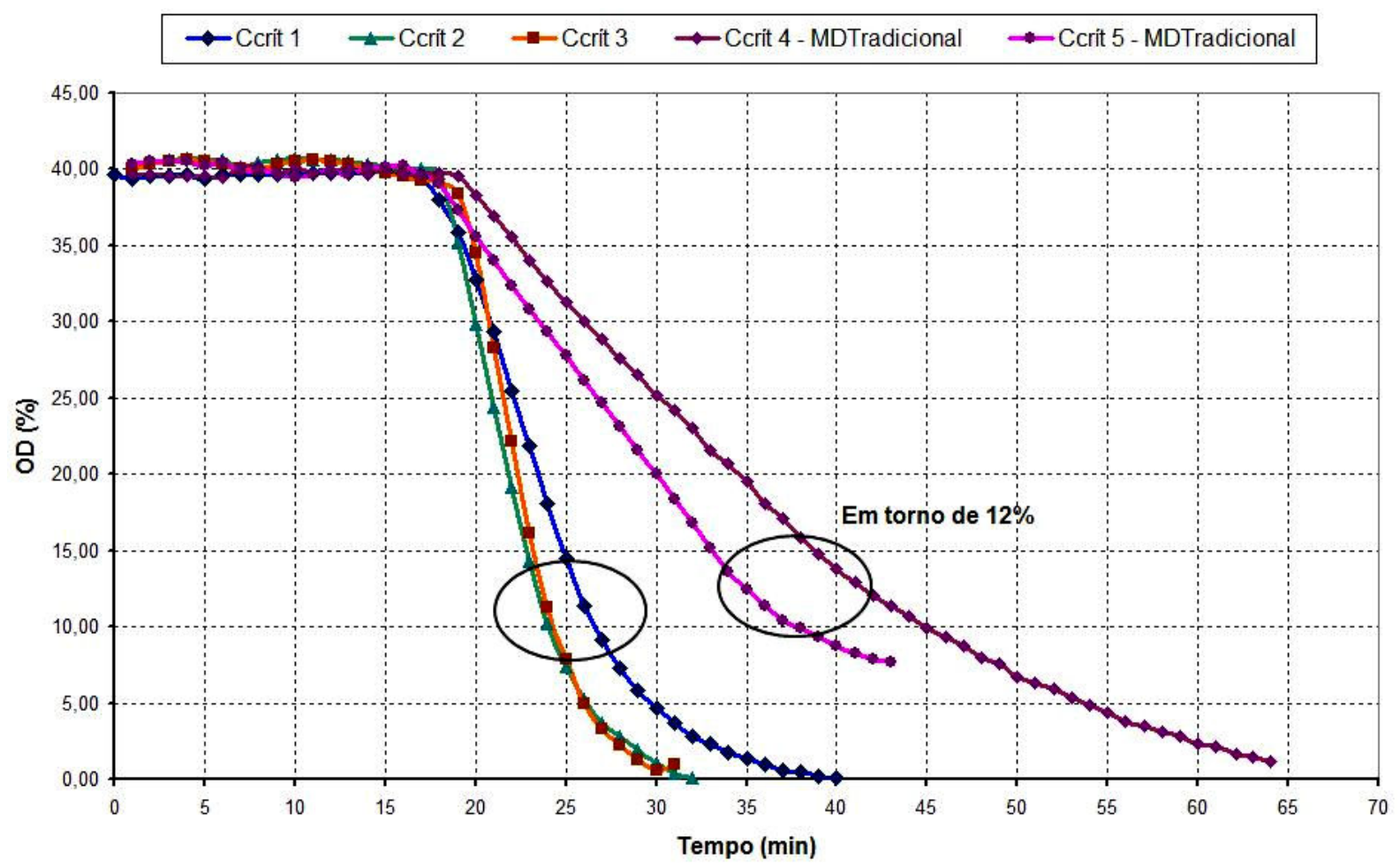

Gráfico 46 - Cálculo do $\mathrm{C}_{\text {critico }}$ em cinco diferentes pontos do cultivo no Ensaio 6 (HBsAg) sendo:

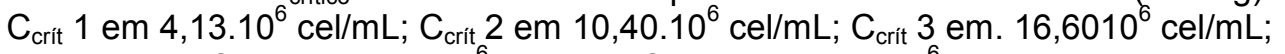
$\mathrm{C}_{\text {crit }} 4 \mathrm{em} 6,60.10^{6} \mathrm{cel} / \mathrm{mL}$ e $\mathrm{C}_{\text {crit }} 5 \mathrm{em} .14,2010^{6} \mathrm{cel} / \mathrm{mL}$. 


\subsubsection{HBsAg secretada}

O antígeno de superfície do vírus da hepatite B (HBsAg) é secretado pela célula transfectada de S2 provavelmente em forma de invólucro viral (DEML; WOLF; WAGNER, 1999) e permanece no caldo de cultura. O HBsAg, segundo testes executados no Laboratório de Imunologia Viral do Instituto Butantan pela Dra. Soraia Attie Calil Jorge, com o caldo fermentado colhido após encerramento deste ensaio, não sofre degradação ao longo do tempo (testes realizados por 5 dias e não apresentados aqui).

Após o $5^{\circ}$ dia, quando foi adicionado o butirato de sódio $(5 \mathrm{mM})$, houve um aumento na quantidade de HBsAg encontrado no lisado das amostras (Gráfico 47), pois o butirato aumenta a expressão gênica geral e, consequentemente do antígeno. No sobrenadante, houve um aumento da quantidade de antígenos nas amostras após 2 dias da adição do butirato, de onde concluí-se que a célula demora 2 dias para secretar totalmente o antígeno para o caldo de cultura (Gráfico 48). Pode ser notado que, quando a cultura está no reator, a quantidade do HBsAg, no sobrenadante, foi aumentando ao longo do tempo (Gráfico 48).

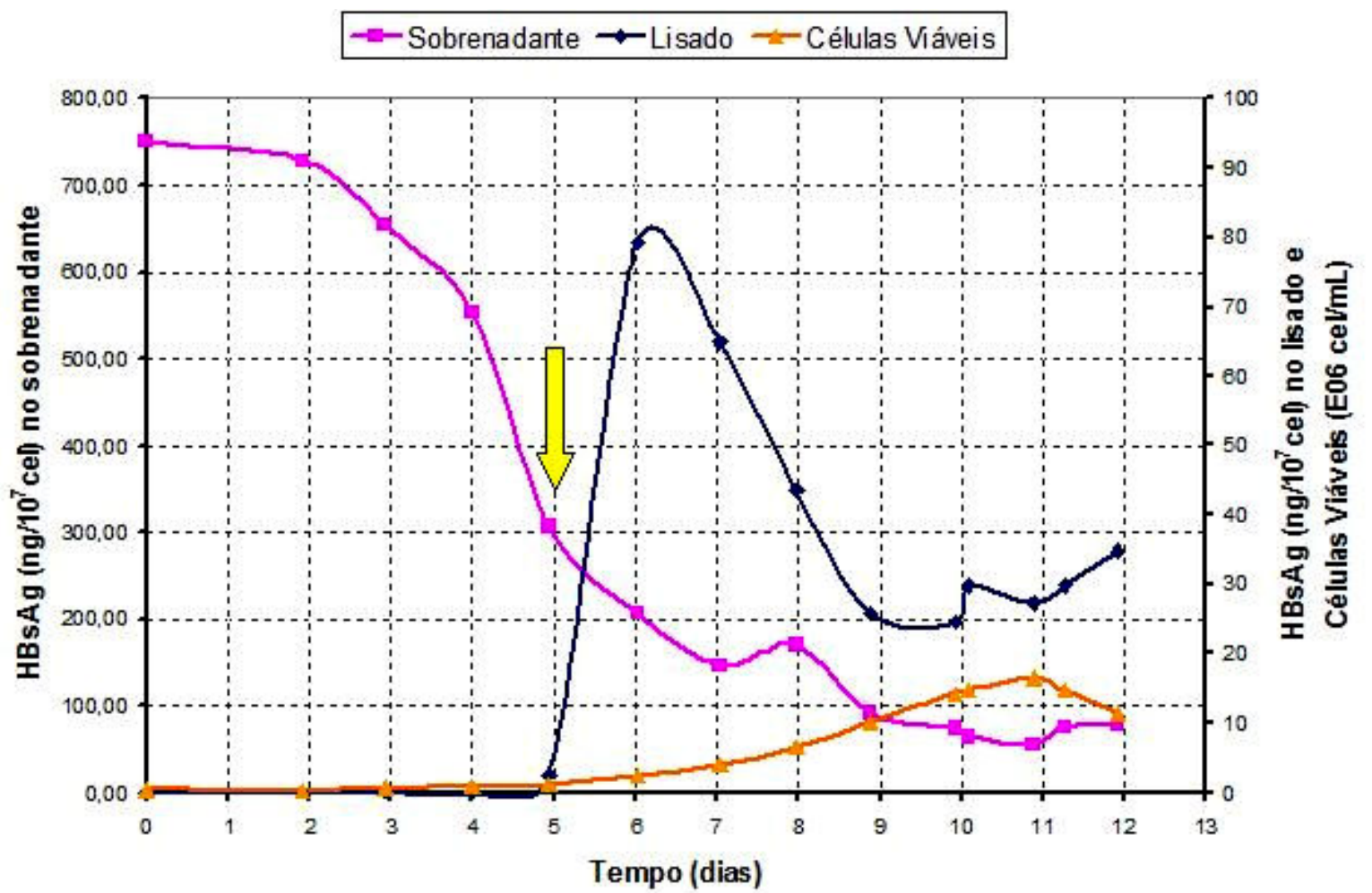

Gráfico 47 - Quantidade de HBsAg secretada ao longo do cultivo no Ensaio 6 (HBsAg), expressa $\left(\mathrm{ng} / 10^{7} \mathrm{cel}\right)$ 


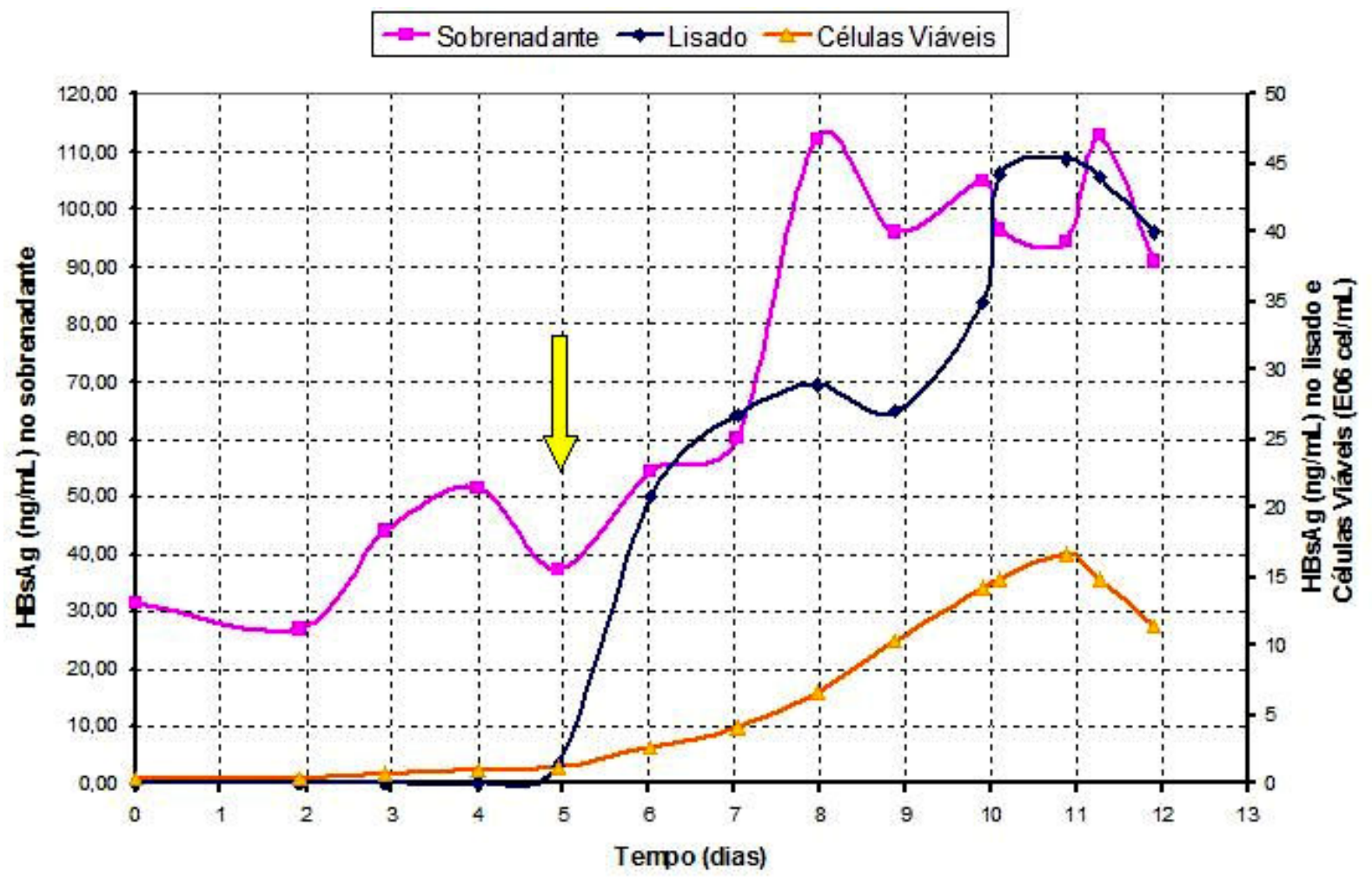

Gráfico 48 - Quantidade de HBsAg secretada ao longo do cultivo no Ensaio 6 (HBsAg), expressa em $(\mathrm{ng} / \mathrm{mL})$

Este ensaio foi terminado logo após ter começado a diminuir a viabilidade celular, pois se desejava guardar o caldo fermentado para posteriores análises e purificação. Após as análises, em teste ELISA, para verificar a quantidade de HBsAg secretado, notou-se que no $10^{\circ}$ dia houve um aumento da quantidade de HBsAg no lisado.

O fato da quantidade de HBsAg no sobrenadante ser bem maior que no lisado, indica uma via de secreção do antígeno viral e, como esse HBsAg não degrada, a quantidade tende a aumentar, pois vai acumulando-o.

As oscilações verificadas na quantidade de HBsAg encontrado nas amostras (tanto no lisado quanto no sobrenadante) podem ser decorrentes de problemas no teste ELISA ou devido a ação de proteases, que exercem um papel importante na degradação das proteínas heterólogas. Havia uma suspeita de que o HBsAg sofresse degradação em $\mathrm{pH}$ ácido, porém após $08^{\circ}$ dia de cultivo $\circ \mathrm{pH}$ já era bem próximo do neutro, sugerindo então que $\circ \mathrm{pH}$ não degradaria $\circ \mathrm{HBsAg}$ nessa situação. 


\subsection{DISCUSSÃO GERAL}

Comparando-se o ensaio da célula Sf9 com os demais ensaios com as células S2 selvagens e transfectadas, observa-se que a Sf9 tem uma velocidade específica de respiração maior que as demais e que o Q 02 gira em torno de 7,47.10-17 mol $\mathrm{O}_{2} /$ (cel.s). Segundo Kioukia et al. (1995) a velocidade específica da Sf9 está entre 3,5 e $9,9.10^{-17} \mathrm{~mol} \mathrm{O}_{2} /$ (cel.s) e segundo Marques (2005) em torno de $6,06.10^{-17} \mathrm{~mol}$ $\mathrm{O}_{2} /$ (cel.s) conforme mostrado na Tabela 8.

Tabela 8 - Quadro comparativo entre ensaios com Sf9

\begin{tabular}{|c|c|c|}
\hline & $\begin{array}{c}\text { Dados de Sf9 } \\
\text { (Ensaio 1) }\end{array}$ & $\begin{array}{c}\text { Dados de Sf9 - Marques } \\
(2005)\end{array}$ \\
\hline$X_{\text {inicial }}($ cel $/ \mathrm{mL})$ & $0,22.10^{6}$ & $0,65.10^{6}$ \\
\hline $\mathrm{X}_{\text {máx }}(\mathrm{cel} / \mathrm{mL})$ & $10,70 \cdot 10^{6}$ & $8,80 \cdot 10^{6}$ \\
\hline $\mathrm{OUR}_{\text {máx }}\left(\mathrm{mmolO}_{2} /(\mathrm{L} . \mathrm{h})\right)$ & 1,26 & 1,22 \\
\hline $\mathrm{Q}_{\mathrm{O} 2 \text { máx }}\left(\mathrm{mol} \mathrm{O} \mathrm{O}_{2} /(\right.$ cel.s $\left.)\right)$ & $74,70.10^{-18}$ & $60,60 \cdot 10^{-18}$ \\
\hline $\mathrm{k}_{\mathrm{L}} \mathrm{a}\left(\mathrm{h}^{-1}\right)$ & 1,44 & 1,30 \\
\hline$\mu_{\text {máx }}\left(\mathrm{dia}^{-1}\right)$ & 0,70 & 0,65 \\
\hline
\end{tabular}

Já as linhagens selvagens de S2 tem uma velocidade específica de respiração de $3,36.10^{-18} \mathrm{~mol} \mathrm{O}_{2} /$ (cel.s) e as transfectadas de 13,00 a $33,63.10^{-18} \mathrm{~mol} \mathrm{O}_{2} /$ (cel.s).

A medida de OUR realizada neste trabalho, feita com as células Sf9 pelo Método Dinâmico Tradicional, está próxima dos valores estimados pelo Balanço na Fase Líquida (BFL), fato que também aconteceu com os ensaios de Marques (2005). Porém, nos ensaios com as células S2 selvagens e transfectadas as medidas de OUR estão distantes dos valores estimados pelo Balanço na Fase Líquida.

Como, através da implantação do Método Dinâmico Proposto, imagina-se que durante a execução do Método Dinâmico Tradicional exista muito oxigênio dentro da membrana de silicone, as células Sf9 por respirarem mais consigam consumir mais rapidamente este oxigênio acumulado. Fato este que já não acontece durante a 
execução do Método Dinâmico Tradicional com as células S2 selvagens e transfectadas. Pode-se reparar ainda que, quanto menor o $\mathrm{Q}_{\mathrm{O} 2}$ da célula (caso da S2AcGPV2) mais distante será a medida da OUR no Método Dinâmico Tradicional da medida no BFL. Enquanto a medida da OUR no Método Dinâmico Proposto chega a ser até coincidente com a medida no BFL. Lembrando ainda que, os valores estimados por BFL são os mais confiáveis, pois utiliza a variação da pressão parcial de oxigênio através da mudança na fração mássica de oxigênio no gás de aeração, calculado diretamente da atuação do controlador MRU do fluxômetro.

No Gráfico 49 são plotados os valores da OUR medida pelo Método Dinâmico Proposto contra os estimados pelo BFL dos três ensaios onde foram calculados (Ensaios 4, 5 e 6). Pode-se observar que todos os pontos estão próximos da linha de tendência, que o coeficiente da equação da reta é praticamente 1 (portanto, perto de uma inclinação de $45^{\circ}$ ) e que o $R^{2}$ da reta também é quase 1 (o que mostra a proximidade dos pontos). Isto indica o quanto próximos estão os valores da OUR medida pelo Método Dinâmico Proposto dos estimados pelo BFL, mostrando assim, a eficiência deste método proposto.

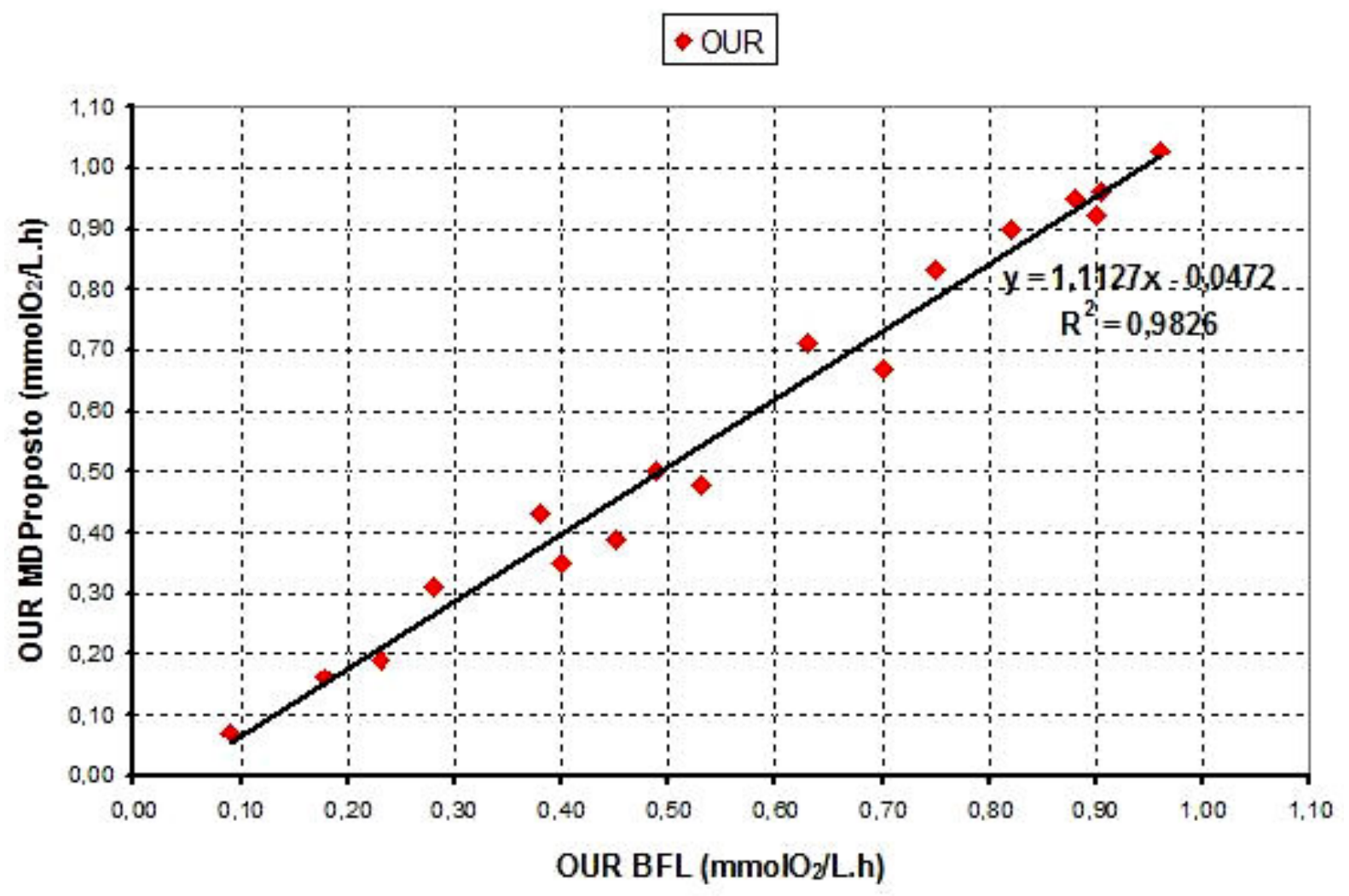

Gráfico 49 - Comparação entre as OURs medidas pelo Método Dinâmico Proposto e BFL. 
Segundo ensaio ${ }^{1}$ com a célula S2AcGPV2 realizado no sistema Cellfrem Pro com meio IPL-41 suplementado (10 g/L de glicose, 0,5 g/L de frutose, $2 \mathrm{~g} / \mathrm{L}$ de lactose, 3,5 $\mathrm{g} / \mathrm{L}$ de glutamina, 0,6 $\mathrm{g} / \mathrm{L}$ de tirosina, 1,48 $\mathrm{g} / \mathrm{L}$ de metionina, $6 \mathrm{~g} / \mathrm{L}$ de yeastolate, $1 \%$ de emulsão lipídica, 0,05 \% PF-68), pH controlado em 6,3 e OD controlado em $40 \%$ foi encontrado um $\mathrm{Q}_{\mathrm{O} 2}$ de $13,2.10^{-18} \mathrm{molO}_{2} /$ (cel.s). Este sistema faz o cálculo automaticamente da OUR e a contagem de células viáveis foi realizado em hemacitômetro. A máxima velocidade específica de crescimento celular foi de 1,10 $\mathrm{dia}^{-1}$.

A diferença entre os valores obtidos pelo Método Dinâmico Tradicional e os demais demonstra que existe um problema na execução deste para biorreatores com transferência de oxigênio através da difusão por membrana de silicone. Esse problema consiste na execução da interrupção do fornecimento de oxigênio, pois se apenas for desligado o fornecimento de oxigênio ainda existirá dentro da membrana uma fração de oxigênio muito alta e que continuará transferindo durante a execução do Método Dinâmico. Mesmo despressurizando a linha ainda existe diferença entre os valores encontrados. Por outro lado, se for passado nitrogênio na membrana os erros passam a ser na direção oposta.

Por isso, principalmente em células que tem um $\mathrm{Q}_{\mathrm{O} 2}$ menor como as $\mathrm{S} 2$, a diferença é significativa, sendo que ainda existe oxigênio na cabeça do reator e dentro da membrana de silicone que possa ser transferido. Assim, as alterações propostas para o Método Dinâmico mostram-se uma boa alternativa para medir-se corretamente a OUR e Qo2.

Nota-se ainda que durante a execução do Método Dinâmico Proposto a agitação e pressurização da linha podem ser mantidas. A manutenção da agitação é importante para manter a homogeneidade da cultura tanto no âmbito da oxigenação quanto para evitar a sedimentação das células e garantir a correta leitura do eletrodo de OD. Outro fator que ficou evidenciado, através dos ensaios, foi o problema que a alta temperatura do cultivo pode provocar, chegando a mostrar-se como um fator inibitório. A influência da temperatura no crescimento celular já havia sido notada por Chuppa et al. (1997).

\footnotetext{
1 Informação recebida da M.Sc. Fabiana Batista no III Workshop sobre biologia molecular e engenharia de bioprocessos para a produção de proteínas recombinantes com células de insetos, 2006, São Carlos/SP.
} 
Neste trabalho pôde-se ainda implementar um método para verificar-se os valores de $\mathrm{C}_{\text {crit }}$ para cada linhagem celular e notou-se que tanto pelo Método Dinâmico Tradicional como pelo Proposto os valores encontrados são correspondentes.

E, finalmente, através dos valores encontrados da atividade respiratória de cada linhagem celular pode-se dizer que as células selvagens e transfectadas são diferentes entre si.

\subsection{NOVA PERSPECTIVA DE DISCUSSÃO}

Diante dos problemas ocorridos com a expressão das proteínas, principalmente a GPV, como a baixa expressão, principalmente em biorreatores, ou ainda o não crescimento de linhagens em biorreatores, começou-se a pensar e discutir algumas possibilidades. Mostrou-se, então, possível que a membrana plasmática tivesse uma grande importância na expressão e manutenção dessas proteínas nas células.

A membrana plasmática cumpre uma vasta gama de funções. A primeira, do ponto de vista da própria célula, é que ela dá individualidade a cada célula. Além de delimitar o ambiente celular, a membrana plasmática representa o primeiro elo de contato entre os meios intra e extracelular, traduzindo informações para o interior da célula e permitindo que ela responda a estímulos externos que podem, inclusive, influenciar no cumprimento de suas funções biológicas (ALBERTS et al. 1997).

A manutenção da individualidade celular, assim como o bom desempenho das outras funções da membrana, requer uma combinação particular de características estruturais da membrana plasmática: ao mesmo tempo em que a membrana precisa formar um limite "estável", ela precisa ser dinâmica e flexível. A combinação destas características é possível devido à sua composição química. (DUTRA, 2007).

Os carboidratos são encontrados exclusivamente na monocamada externa de membranas plasmáticas e podem interagir com as proteínas formando as glicoproteínas (JUNQUEIRA; CARNEIRO, 1997).

As membranas celulares consistem de uma dupla camada contínua de lipídeos, com a qual proteínas e carboidratos das mais diversas naturezas interagem das mais diferentes maneiras. Justamente a bicamada lipídica é que confere estabilidade e 
flexibilidade, ao mesmo tempo, à membrana. Os lipídeos são os componentes que compõe a estrutura básica da membrana. Na Figura 25, tem-se o Mosaico Fluído sugerido por Singer e Nicholson em 1972 e aceito até hoje para explicar a bicamada da membrana plasmática (ALBERTS et al., 1997).

A molécula de fosfolipídeo possui uma característica bioquímica essencial para formar uma bicamada estável, ainda que fluida. Ela possui uma região hidrofílica e caudas hidrofóbicas. Enquanto que a região hidrofílica interage bem com a água, altamente abundante nos meios intra e extracelular, a região hidrofóbica busca "esconder-se" da água. A intenção natural destas moléculas anfipáticas, ou seja, composta por regiões hidrofóbica e hidrofílica, de atingir um estado que seja energeticamente estável e termodinamicamente favorável, faz com que elas se arranjem na forma de uma bicamada.

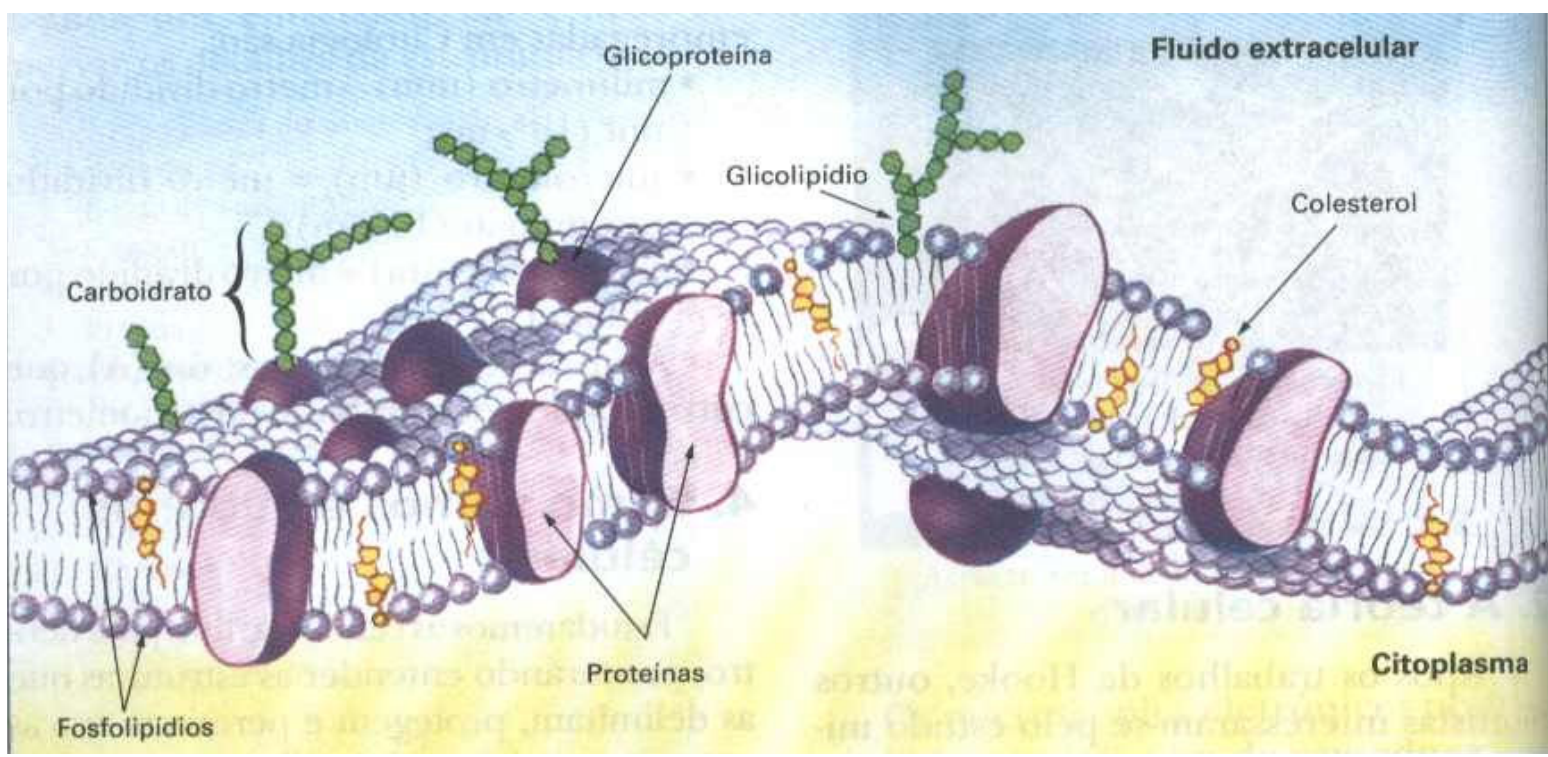

Figura 25 - Mosaico Fluído sugerido por Singer e Nicholson (Adaptado de ALBERTS et al., 1997).

A estabilidade é, então, dada pela necessidade termodinâmica do próprio fosfolipídeo em manter suas regiões hidrofílica e hidrofóbica em posições adequadas em relação à água. Desta forma, se a bicamada lipídica sofre um dano, onde algumas moléculas são removidas, sua tendência natural é a de se regenerar (ALBERTS et al., 1997).

Os lipídeos distribuem-se assimetricamente nas duas monocamadas lipídicas e estão em constante movimentação. Eles movem-se ao longo do seu próprio eixo, num movimento chamado rotacional e movem-se lateralmente ao longo da extensão da camada. Estes dois movimentos não representam qualquer alteração à 
termodinâmica natural da membrana e, portanto, ocorrem constantemente. Um outro movimento chamado flip-flop, que consiste em mudar de uma monocamada a outra, é menos freqüente, pois envolve a passagem da cabeça polar (hidrofílica) dentro da região apolar (hidrofóbica) da bicamada (ALBERTS et al., 1997).

A fluidez da membrana é definida como a facilidade com a qual as moléculas lipídicas movem-se no plano da bicamada. A uma determinada temperatura, depende da composição dos fosfolipídeos e, principalmente das caudas de hidrocarbonetos. A fluidez da membrana é controlada por diversos fatores físicos e químicos (FRAGA, 2006):

- A temperatura influencia na fluidez: quanto mais alta ou baixa, mais ou menos fluída será a membrana, respectivamente.

- A concentração de colesterol influencia na fluidez: quanto mais colesterol, menos fluída. O colesterol, por ser menor e mais rígido, interage mais fortemente com os lipídeos adjacentes, diminuindo sua capacidade de movimentação na bicamada.

- A cauda de carboidratos das glicoproteínas influencia na fluidez pois, quanto mais próximas as caldas menos fluída será a bicamada, e quanto mais comprida as caudas menos fluída será a bicamada, pois apresentará maior interação entre as caudas.

- A presença de álcool no meio extracelular aumenta a fluidez da bicamada, o que explica porque o polietilenoglicol é um protetor celular.

O Pluronic F68 atua também na redução da fluidez da membrana plasmática. Em cultura de células de mamíferos, o aumento da rigidez da membrana pela adição de colesterol e aumento da fluidez da membrana pela adição de álcool benzílico mostraram a relação entre rigidez da membrana e proteção ao cisalhamento, sendo maior a proteção para uma membrana mais rígida (CHISTI, 2000).

Considerando-se a interação das proteínas com a bicamada lipídica, as proteínas podem ser classificadas como: ancoradas, periféricas ou transmembrana (integrais). Naturalmente, que as proteínas também possuem características estruturais que as permitem interagir com a bicamada lipídica (JUNQUEIRA; CARNEIRO, 1997). 
Com o exposto acima, pode-se sugerir algumas explicações para as situações encontradas durante este trabalho e também fazer-se algumas considerações:

- A célula S2AcGPV2 apresentou uma expressão baixa em relação a outras proteínas heterólogas expressas. Isso indica que existe pouca GPV (em sua forma trimérica) expressa em cada célula, mantendo-se então, a continuidade da fluidez da membrana, por não haver uma grande interação entre as caudas de carboidratos. Existe ainda a possibilidade de que a cauda de carboidrato da glicoproteína possa ser arrancada pelo gradiente de velocidade causado pela pá do reator, fazendo com que, em biorreator, as células S2AcGPV2 expressem pouco. E, como visto acima, apesar de ter a cauda arrancada a célula pode se regenerar, porém não mais apresentando a forma trimérica naquela proteína.

- No ensaio realizado com as células S2AcGPV2 (E4) houve uma fase lag de dois dias apesar de o inóculo ter sido de $0,50.10^{6} \mathrm{cel} / \mathrm{mL}$ e durante essa fase lag aproximadamente $4 \%$ das células deixaram de ser viáveis. Isso pode sinalizar que as células que mais expressavam sofreram ao serem agitadas no reator, como comentado anteriormente.

- Durante este trabalho procedeu-se a um ensaio com uma outra linhagem celular, a S2AcGPVHy (célula transfectada por Alexandra Santos no Laboratório de Imunologia Viral do Instituto Butantan). Tal linhagem foi construída através de um único plasmídeo com codificação para GPV e Higromicina e expressava, em Schott, o dobro da quantidade de GPV expressa pela S2AcGPV (resultados não apresentados). Quando a S2AcGPVHy foi colocada no reator, ela não conseguiu crescer e depois de 1 dia começou a morrer. A explicação que se pode sugerir a partir do estudo da membrana plasmática, é que, como havia mais GPV, também existiam mais caudas de carboidratos e, portanto, a proximidade das caudas fez com que a membrana ficasse muito rígida (pouco fluída). Essa rigidez pode ter ocasionado o seguinte problema: se a cauda de carboidratos pode ser arrancada pelo gradiente de velocidade causado pela pá do biorreator, e como havia muitas caudas interagidas e, portanto, agrupadas, a célula acabou sofrendo uma degradação na membrana celular ao ter as caudas arrancadas, sem possibilidade de regeneração. 
- Já foi obtido no Laboratório de Imunologia Viral do Instituto Butantan através de teste ELISA, valores altos de expressão de GPV em frasco $T$, valores estes maiores que encontrados com a mesma célula depois em Schott. Isto pode ser explicado, pois em frasco $T$ a célula que expressa GPV não sofre nenhum tipo de dano que cause cisalhamento (na célula ou na GPV).

- A S2AcGPV2 em biorreator deve ter uma condição onde a GPV expressa consiga manter-se na membrana, sem ser arrancada facilmente, mas também não chegando a formar uma grande interação entre as caudas de carboidratos. Deve-se, no futuro, testar várias temperaturas abaixo de $28^{\circ} \mathrm{C}$, pois se a cultura for mantida a temperaturas inferiores a que se trabalhou $\left(28^{\circ}\right.$ C), a membrana plasmática terá sua fluidez diminuída, a ponto de segurar mais firmemente a cauda de carboidrato, porém, sem estar extremamente rígida a ponto de não conseguir regenerar-se. Em ensaios ${ }^{1}$ em Schott a $22^{\circ} \mathrm{C}$ e meio Sf900II SFM o cultivo com a célula S2AcGPV2 chegou a 105,6 ng/mL de GPV, o que reforça o exposto anteriormente.

- Após sucessivas passagens em um mesmo frasco T, a S2AcGPV2 apresentou uma seleção de células que expressam bem. Esse experimento ocorreu no Laboratório de Imunologia Viral do Instituto Butantan e foi realizado pro Kátia Greco. Esse fato pode ser explicado, pois, como se sucedeu 13 passagens no mesmo frasco $\mathrm{T}$, havia aderido à parede do frasco células que expressam GPV, e também GPVs oriundas de células que tiveram sua membrana celular rompida. Assim, formou-se um "tapete" com várias GPVs que começaram a interagir com as caudas das GPVs das outras células e por fim selecionando a linhagem.

- Talvez a diferença entre as células S2AcGPV, S2MtEGFP e S2AcHBsAgHy possa ser explicada pela interação de cada proteína expressa com a membrana, uma vez que são proteínas diferentes, elas também poderão ter uma interação diferente com a membrana. Deve-se lembrar que a S2MtEGFP sofreu uma mudança de comportamento após a indução (quando passou a

\footnotetext{
${ }^{1}$ Informação recebida da Dra. Kamilla Swiech no III Workshop sobre biologia molecular e engenharia de bioprocessos para a produção de proteínas recombinantes com células de insetos, 2006, São Carlos/SP.
} 
expressar) e que a membrana plasmática está intimamente ligada ao cumprimento das funções biológicas.

- A adição de Pluronic F68 deve ser testada em várias dosagens a fim de se verificar qual a quantidade ideal a ser adicionada, para que ele proteja a célula, enrijecendo-a, sem, no entanto, tirar a estabilidade da fluidez.

\subsection{CONTINUIDADE DO TRABALHO}

A seguir são apresentadas algumas idéias e sugestões para pesquisas futuras e continuidade do presente trabalho.

- Continuação do estudo da diferença do Método Dinâmico tradicional e proposto para novas linhagens celulares de $\mathrm{S} 2$, calculando também o $\mathrm{C}_{\text {crit }}$ delas, para confirmação dos métodos implantados.

- Realizar novos ensaios com as linhagens selvagem e transfectadas de S2, alterando condições de agitação (diferentes pás) e temperaturas (mais baixas) para verificar a melhor condição de crescimento celular e expressão de proteínas heterólogas para cada tipo de linhagem transfectada.

- Verificação, para as células transfectadas indutíveis, qual o melhor momento de indução quando se trabalha em um biorreator.

- Estudo da fisiologia e citologia das células S2 selvagem e transfectadas e qual a influência da expressão de proteínas heterólogas na fluidez da membrana plasmática.

- Repetição de ensaios, no sentido de se poder avaliar melhor a reprodutibilidade dos resultados. 


\section{CONCLUSÃO}

Como apresentado e discutido neste trabalho as principais conclusões são:

- Valores máximos do crescimento celular e atividade respiratória em fase exponencial das células estudadas obtidos através do Método Dinâmico Proposto:

Tabela 9 - Quadro síntese dos resultados

\begin{tabular}{|c|c|c|c|c|c|}
\hline $\begin{array}{l}\text { Linhagem } \\
\text { celular }\end{array}$ & $\begin{array}{c}X \\
(\text { cel } / \mathrm{mL})\end{array}$ & $\begin{array}{c}\text { Tempo } \\
\text { para atingir } \\
\mathrm{X}_{\mathrm{Max}} \\
\end{array}$ & $\begin{array}{c}\mu_{\max } \\
\left(\mathrm{dia}^{-1}\right)\end{array}$ & $\begin{array}{c}\text { Intervalo } \\
\text { de } \mu_{\operatorname{Max}}\end{array}$ & $\begin{array}{c}Q_{02} \text { máx } \\
\left(\mathrm{mol} \mathrm{O}_{2} \cdot \mathrm{cel}^{-1} \cdot \mathrm{s}^{-1}\right)\end{array}$ \\
\hline Sf9 & $10,7.10^{6}$ & 7,8 dias & 0,70 & 6,2 dias & $74,7.10^{-18}$ \\
\hline S2 & $51,2.10^{6}$ & 4,0 dias & 1,07 & 2,8 dias & $3,36 \cdot 10^{-18}$ \\
\hline S2AcGPV2 & $26,6.10^{6}$ & 7,8 dias & 1,26 & 1,0 dia & $16,04.10^{-18}$ \\
\hline $\begin{array}{l}\text { S2Mt EGFP } \\
\text { (antes/ pós } \\
\text { indução) }\end{array}$ & $17,8.10^{6}$ & 5,9 dias & $\begin{array}{c}0,68 / \\
0,38\end{array}$ & $\begin{array}{c}3,2 \text { dias/ } \\
1,4 \text { dias }\end{array}$ & $\begin{array}{c}25,75 \cdot 10^{-18} / \\
13,00 \cdot 10^{-18}\end{array}$ \\
\hline $\begin{array}{l}\text { S2AcHBsAgHy } \\
\text { (antes/ pós } \\
\text { adição butirato }\end{array}$ & $16,6.10^{6}$ & 10,8 dias & $\begin{array}{l}0,64 / \\
0,48\end{array}$ & $\begin{array}{c}4,0 \text { dias/ } \\
1,2 \text { dias }\end{array}$ & $33,63.10^{-18}$ \\
\hline
\end{tabular}

- Temperaturas acima de $30^{\circ} \mathrm{C}$ atuam como inibidoras do crescimento celular em linhagens S2, alterando a velocidade específica de respiração em até $60 \%$.

- O método dinâmico implantado neste trabalho, com o controle da fração de oxigênio na mistura gasosa da cabeça do reator e na membrana de silicone, mostrou que no método dinâmico tradicional mesmo cortando a vazão gasosa, a agitação e despressurizando a membrana de silicone, ainda existe muito oxigênio disponível. Por essa razão, o $Q_{02}$ no método dinâmico tradicional chega a ser $8 \%$ do Q 02 medido no método dinâmico proposto (como no caso do Ensaio 4 (GPV)). 
- O método implantado neste trabalho para avaliação de $\mathrm{C}_{\text {crit }}$, através da alteração da inclinação da queda de concentração de oxigênio dissolvido, mostrou-se adequado tendo-se obtido os seguintes valores:

Tabela 10 - Valores de $\mathrm{C}_{\text {crit }}$ obtidos

\begin{tabular}{lc}
\multicolumn{1}{c}{ Linhagem } & \multicolumn{1}{c}{$\mathbf{C}_{\text {crít }}$} \\
\hline S2 & Em torno de 10\% \\
S2AcGPV2 & Em torno de 10\% \\
S2MtEGFP & Em torno de 5\% \\
S2AcHBsAgHy & Em torno de 12\% \\
\hline
\end{tabular}

- As células de S2 selvagem e transfectadas comportaram-se diferentemente, pois apresentaram atividade respiratória e crescimento celular diferentes umas das outras. 


\section{REFERÊNCIAS ${ }^{*}$}

AGATHOS S.N. Production scale insect cell culture. Biotechnology advances, v.9, p.51-68, 1991. . Insect cell bioreactors. Cytotechnology, v.20, p.173-189, 1996.

ALBERTS, B.; BRAY, D.; LEWIS, J.; RAFF, M.; ROBERTS, K.; WATSON, J. Biologia molecular da célula. 3 ed. São Paulo: Artes Médicas, 1997. 1294p.

ARDAILLON-SIMÕES, D.; ARROYO, G.; URIBELARREA, J-L. (1994) Logiciel du Lissage (Software).

AUGUSTO, E.F.P.; OLIVEIRA, M.S. Processos com células animais. In: LIMA, U.A.; AQUARONE, E.; BORNAZI, W.; SCHMIDELL, W., Biotecnologia industrial. São Paulo: Edgard Blücher, 2001. v.3, cap.24, p.547-582.

BENTING, J.; LECAT, S.; ZACCHETTI, D.E.; SIMONS, K. Protein expression in Drosophila Shneider cells. Analytical biochemistry. v.278, p.59-68, 2000.

BÉRDARD, C.; TOM, R.; KAMEM, A. Growth, nutrient consumption, and end product accumulation in Sf9 and BTI-EAA insect cell cultures: insights into growth limitation and metabolism. Biotechnology progress. v.9, p.615-624, 1993.

BHATIA, R.; JESIONOWSKI, G.; FERRANCE, J.; ATTAI, M.M. Insect cell physiology. Cytotechnology. v.24, p.1-9, 1997.

BOVO, R. Otimização de bioprocesso de cultura de células de Drosophila melanogaster (S2) através de estudos de suas condições metabólicas. Dissertação (Mestrado). 2006. 49p. Programa de pós-graduação interunidades em Biotecnologia USP/Instituto Butantan/IPT. 2006

\footnotetext{
*De acordo com:

ESCOLA POLITÉCNICA DA UNIVERSIDADE DE SÃO PAULO. Divisão de Biblioteca. Diretrizes para apresentação de dissertação e teses. $3^{a}$ ed. São Paulo: 2006. 103p. Disponível em: <http://www.poli.usp.br/Bibliotecas/PublicacoesOnLine/Diretrizes3.pdf>. Acesso em: 28 mai. 2007
} 
BRIGHTY, D.W.; ROSENBERG, M.; CHEN, I.S.Y.; IVEY-HOYLE, M. Envelope proteins from isolates of human immunodeficiency virus type-I that are refractory to neutralizations by soluble CD4 receptor. In: National academy of sciences. 1991. USA. Proc. natl. academy science USA. v.88, p.7802-7805, 1991.

BUCKINGHAM, S.D.; MATSUDA K.; HOISE, A.M.; BAYLIS, H.A.; SQUIRE, M.D.; LANSDELL, S.J.; MILLAR, N.S.; SATELLE, D.B. Wild-type and insecticide resistant homo-oligomeric GABA receptors of Drosophila melanogaster stably expressed in a Drosophila cell line. Neuropharmacology. v.35, p.1393-1401,1996.

CARON, A.W.; TOM, R.L.; KAMEN, A.A.; MASSIE, B. Baculovirus expression system scaleup by perfusion of high-density Sf9 cell cultures. Biotechnology Bioengineering. v.43, p.881-891, 1994.

CASTRO, M. E., SOUZA, M. L., BILIMORIA, S. L. Host-specific transcription of nucleopolyhedrovirus gene homologues in productive and abortive Anticarsia gemmatalis MNPV infections. Arch. virol. v.144 p.1111-1121, 1999.

CCAUFES - Centro de ciência agrária da universidade federal do Espírito Santo. Disponível em: <http:// www.cca.ufes.br>. Acesso em: 28 mai. 2007.

CESTARI, A.N.; SIMÕES, L.C.G. Cultura de tecidos de insetos. Simpósio sobre cultura de células. São Pualo. Anais .... São Paulo, ACIESP. n.10, p.143-191, 1978.

CHEN T; SUN H.; ZHAO Y.; TAO D.; LI X.; HUANG B. Histone acetylation is involved in hsp 70 gene transcription regulation in Drosophila melanogaster. Arch. bioch. biophys, v.408, p.171-176, 2002.

CHERBAS, L.; MOSS, R.; CHERBAS, P. Transformation techniques for Drosophila cell lines. Methods in cell biology. v.44, p.161-179, 1994.

CHISTI, Y. Animal-cell damage in sparged bioreactors. Trends in biotechnology. v.18, p.420-432, 2000.

CHUNG, I.S.; TATICEK, R.A.; SHULER, M.L. Production of human alkaline phosphatase, a secretal, glycosylated protein, from a baculovírus expression system and the attachment-dependent cell line Trichoplusia ni BTI-Tn 5B1-4 using a splitflow, air-lift by bioreactor. Biotechnology progress. v.9, p.675-678, 1993. 
CHUPPA S., TAI Y-S.; YOON S.; SHACKLEFORD S.; ROZALES C.; BHAT R.; TSAY G.; MATANGUIHAN C.; KONSTANTINOV K.; NAVEH D. Fermentor temperature as a tool of control of high-density perfusion culture mammalian cells. Biotech and Bioeng. v. 55, p.328-338, 1997.

COELHO, S. Método permite encontrar seqüências ocultas do genoma. In: Ciência hoje. São Paulo: 19.02.2002.

DELM, L.; WOLF, H.; WAGNER, R.. Hight level expression of hepatitis B virus superface antigen in stably transfected Drosophila Schneider 2 cells. Journal virology methods. v.79, p.191-203, 1999.

DEUTSCHMANN, S.M,; JÄGER, V. Optimization of growth conditions of Sf21 insect cells for high-density perfusion culture in stirred-tank bioreactors. Enzyme and microbiology technology. v.16, p.506-512, 1994.

DREWS, M.; PAALME, T.; VILU, R. The growth and nutrient utilization of the insect cell line Spodoptera frugiperda Sf9 in batch and continuous culture. Journal of biotechnology. v.40, p.187-198, 1995.

DUTRA, W.O. Membrana Plasmática. Material de apoio do curso de biologia celular do instituto de ciências biológicas da universidade federal de Minas Gerais. Minas Gerais: UFMG, 2006. Disponível em: <http://www.icb.ufmg.br/mor/biocelch Imembrana /membrana.html> Acesso em: 28 mai. 2007.

FERRANCE J.P.; GOEL A.; ATAAI M.M. Utilization of glucose and amino acids in insect cell cultures: quantifying the metabolic flows within the primary pathways and medium development. Biotechnology Progress. v. 42, p.697-707, 1993.

FLEISCHAKER, R. J.; WEAVER, J. C.; SINSKEY, A. J. Instrumentation for process control in cell culture. Advances in applied microbiology. v.27, p.137-167, 1981.

FRAGA, L. Citologia, histologia e introdução à biologia molecular. Material de apoio do curso de especialização em fisiologia do exercício. Minas Gerais: Instituto Aleixo, 2002. Disponível em: <http://www.aleixomkt.com.br/fisio/65.pdf> Acesso em: 28 mai. 2007.

FRESHNEY, R.I. Culture of animal cells: A Manual of Basic Technique. Wiley-Liss. $3^{\text {rd }}$ Ed. p.25-42, 1994. 
GEMANO, P.M.L. Avanços na pesquisa da raiva. Revista de saúde pública, v.28, p.38-48, 1994.

GOMBERT, A.K. Apêndice de cinética de processos fermentativos In: SCHMIDELL, W.; LIMA, U.A.; AQUARONE, E.; BORNAZI, W. Biotecnologia industrial. São Paulo: Edgard Blücher, 2001. v.3, cap.6, p.114-120.

GOOSEN, M. Insect cell culture engineering: an overview. In: GOOSEN, F.A.M.; DAUGULIS J.A.; FAULKNER, P., Insect cell culture engineering, New York: Marcel Dekker, 1993. cap.1, p.1-16.

GRACE, T.D.C. Analysis of the aminoacids and sugar in an insect cell medium during cell growth. Journal insect physiology. v.12, p.625-633, 1966.

Prolonged survival and growth of insect ovarian tissue in vitro conditions. Annals of New York academy of sciences. v.77, p.275-282, 1959.

GUY, E. Drosophila cell in culture. San Diego, Academy press. p.702, 1997.

HEPCENTRO. Hepatite B. Disponível em: <www.hepcentro.com.br/hepatite b.htm> Acesso em: 28 mai. 2007.

IKONOMOU, L.; SCHNEIDER, Y-J; AGATHOS, S.N. Insect cell culture for industrial production of recombinant proteins. Applied microbiology and biotechnology. v.62, p.1-20, 2003.

INSTITUTO FLEURY. Manual Fleury de diagnósticos em hematologia. Disponível em: <http://www.institutoifleury.org.br/educacao/manuais/manual hemato/capitulo2. htm>. Acesso em: 28 mai. 2007.

IVEY-HOYLE, M. Recombinant gene expression in cultured Drosophila melanogaster cells. Current opinion in biotechnology. v.2, p.704-707, 1991.

JUNQUEIRA, L.C.; CARNEIRO, J. Biologia celular e molecular. $6^{\text {a }}$ ed. Rio de Janeiro: Guanabara Coogan, 1997. 299p.

KAMEN A.A.; BERDAD C.; TOM R.; PERRET S.; JARDIN B. On-line monitoring of respiration in recombinant-baculovirus infected and uninfected insect cell bioreactor cultures. Biotechnology and Bioengineering. v.50, p.36-48, 1996. 
KIOUKIA, N.; NIENOW, A. W.; EMERY, A. N.; ALBUREAI, M. Physiological and environmental-factors affecting the growth of insect cells and infection with baculovirus. Journal of biotechnology. v.38, p.243-251, 1995.

LE DUY, A.; ZAJIC, J.E. A geometrical approach for differentiation of an experimental function at a point: applied to growth and product formation. Biotechnology and Bioengineering. vol.15, n.4, p.805-810, 1973.

LEE, E.K.; HUANG, L.; LEE, Y. H. Effect of liquid properties and flow on liquid film mass transfer coefficient in silicone membrane oxygenation. Biotechnology and Bioengineer, v.36, p.530-533, 1990.

LEE, J.M., PARK, J.H.; PARK, J. O.; CHANG, K. H.; CHUNG, I. S. Expression of recombinant erythroprotein in stably transformed Drosophila melanogaster S2 cell. In vitro cell dev. biology. v.3, p.348-350, 2000.

LI, B.; TSING, S.; KOSAKA, A.H.; NGUYEN, B.; OSEN, E.G.; BACH, C.; CHAN, H.; BARNETT, J. Expression of human dopamine $\beta$ hydroxylase in drosophila Schneider 2 cells. Biochemical journal. v.313, p.57-64, 1996.

MARQUES, F.H. Influência do oxigênio dissolvido na produção de poliedros de baculovírus por células de inseto em biorreator. Dissertação (Mestrado). 2005. 102p. Programa de Pós-Graduação Interunidades em Biotecnologia USP/Instituto Butantan/IPT. 2005.

MCCARROLL, L.; KING, L. Stable insect cell cultures for recombinant protein production. Current opinion in biotechnology. v.8, p.590-594, 1997.

MENDONÇA, R.Z.; PALOMARES, L.A.; RAMÍREZ, O.T. An Insight into Insect Cell Metabolism Through Selective Nutrient Manipulation. Journal of biotechnology. v.72, p.61-75, 1999.

MITSUHASHI, J. Invertebrate cell system application. Boca Raton, CRC, v.2, p.3-20, 1989.

MOSCARDI, F., SOUZA, M. L. Baculovírus para o controle de pragas. Panacéia ou realidade? Biotecnologia, Ciência \& Desenvolvimento, v.24, p.22-29, 2002.

ÖHMAN, L.; ALARCON, M.; LJUNGGREN, J.; RAMQVIST, A.K; HAGGSTROM, L. Glutamine is not an essential amino acid for Sf9 Insect Cell. Biotechnology letters. v.18, p.756-770, 1996. 
ÖHMAN, L; LJUNGGREN, J.; HAGGSTROM, L. Induction of a metabolic switch in insect cell by substrate-limited fed batch cultures. Applied microbiology and biotechnology. v.43, p.1006-1013, 1995.

PATERSON, G. H.; KNOBEL, S. M.; SHARIF, W. D.; KAIN S. R.; PISTON, D. W. Use of the green fluorescent protein and its mutants in quantitative fluorescent microscopy. Biophys journal. v.73, p.2782-2790, 1997.

PÉREZ, O.; PAOLAZZI, C.C. Production methods for rabies vaccine. Journal of industrial microbiology and biotechnology. v.18, p.340-347, 1997.

PERKINS J. A. Medical and scientific illustrations infectious disease. Disponível em: <http://www.rti.edu/ japfaa/index.html> Acesso em: 28 mai. 2007.

PFEIFER, T.A.; HEGEDUS, D.D.; GRIGLIATTI, T.A.; THEILMANN, D.A. Baculovirus immediate-early promoter-mediated expression of the Zeocin resistance gene for use as a dominant selectable marker in dipteran and lepidopteran insect cell lines. Gene. v.188, p.183-190, 1997.

PRASHER, D. C.; ECKENRODE, V.K.; WARD, W. W.; PRENDERGAST, F.G.; COMIER, M. J. Primary structure of Aqueorea victoria green fluorescent protein. Gene. v.111, p.229-233, 1997.

QI, H.N.; GOUDAR, C.T.; MICHAELS, J.D.; HENZLER, H-J; JOVANOVIC, G.N.; KONSTANTINOV, K.B. Experimental and theoretical analysis of tubular membrane aerations for mammalian cell bioreactors. Biotechnology progress. v.19, p.11831189, 2003.

RICE, J.W; RANKI, N.B.; GURGAMES, T.M.; MARR, C.M.; BARNA, J.B.; WALTERS, M.M.; BURNS, D.J. A comparison of largscale Sf9 insect cell growth and protein production - stirred vessels vs. airlift. Biotechniques. v.15, p.1052-1061, 1993.

SANTOS, M. G. Expressão do gene da proteína verde fluorescente (EGFP) em células de Drosophila melanogaster como instrumento de otimização de bioprocesso para a produção de proteínas heterólogas. 2006. 59p. Dissertação (Mestrado). Programa de pós-graduação interunidades em Biotecnologia USP/Instituto Butantan/IPT. 2006.

SCHATZMAYR, H. G. Emerging and reemerging viral diseases. Cad. saúde pública. v.17, p.209-213, 2001. 
SCHMIDELL, W. Agitação e aeração em biorreatores. In: SCHMIDELL, W.; LIMA, U.A.; AQUARONE, E.; BORNAZI, W. Biotecnologia industrial. São Paulo: Edgard Blücher, 2001. v.2, cap.14, p.277-331.

SCHNEIDER, I. Cell lines derived from late embryonic stages of Drosophila melanogaster. Journal embryologic exp. morphologic, v.27, p.363-365, 1972.

SCHUMPE, A. Gás Solubilities in Biomedia. In: REHN, H.J.; REED, G., Biotechnology: a comprehensive treatise in 8 volumes. Germany: $H$. Brauer, 1986. vol.2, cap.10, p. 159-170, 1985.

SINGH, V. Disposable bioreactor for cell culture using wave-induced agitation. Cytotechnology. v.30, p.149-158, 1999.

SUMMERS, M.D.; SMITH, G. E. A manual of methods for baculovírus vectors and insect cell culture procedure. Texas agric. experiment station. v.9, p.1-56, 1987.

THOMPSON S.N.; BORCHARDT D. B.; WANG L.W. Dietary nutrient levels regulate protein and carbohydrate intake, gluconeogenic/glycolytic flux and blood trehalose level in the insect Manduca sexta L. Journal comp. pysiology [B], v.173(2), p.149163, 2003.

TONSO, A. Monitoramento e Operação de cultivos de células animais em sistema de perfusão. 2000. 136p. Tese (Doutorado). Escola Politécnica da Universidade São Paulo, Engenharia Química. 2000.

TRAMPER, J.; VLAK, J.M.; GOOIJER, C.D. Scale up aspects of sparged insect cell bioreactors. Cytotechnology. v.20, p.221-229, 1996.

U.S. GEOLOGICAL SURVEY. Solubility of oxygen in water at various temperatures and pressures - Table 6.2-6, - Disponível em: <http://water.usgs.gov/owq /FieldManual/Chapter6/table6.2 6.pdf> Acesso em 28 mai. 2007.

VAN DER POL, L.; TRAMPER, J. Shear sensitivity of animal cells from a culture medium perspective. Trends in biotechnology. v.16, p.323-328, 1998.

VAN LIER, F.L.J.; VAN DEN HOMBERGH J.P.T.W.; DE GOOIJER C.D.; DEN BOER M.M.; VLAK J.M.; TRAMPER J. Long-term semi-continuous production of recombinant baculovirus protein in a repeated (fed-)batch two-stage reactor system. Enzyme microbial technology. v.18, p.460-466, 1996. 
VAUGHN, J.L.; FAN, F. Differential requirements of two insect cell lines for growth in serum-free medium, in vitro. Cellular and developmental biology, v.33, p.479-482, 1997.

VERMA, R., BOLETI, E., GEORGE, A.J.T. Antibody engineering: comparison of bacterial, yeast, insect and mammalian expression system. Journal of immunological methods. v.216, p.165-181, 1998.

WANG, M-Y.; KWONG, S.; BENTLEY, W.E., Effects oxygen/glucose/glutamine feeding on insect cell baculovírus protein expression: a study on epoxide hydrolase production. Biotechnology program, v.9, p.355-361, 1993.

WARD, W. W.; PRENTICE, H. J.; ROTH, A. F.; CODY, C.W.; REEVES, S. C. Spectral pertubations of the Aqueorea green fluorescent protein. Photochem. photobiol. v.35, p.803-808, 1982.

WILKIE, G.E.I.; STOCKDALE, H.; PIRT, S.V. Chemical defined media for production of insect cells and viruses in vitro. Developments in biological standardization. v.46, p.29-37, 1980.

YOKOMIZO A.Y. Expressão do gene da glicoproteína do vírus da raiva (GPV) em células de Drosophila melanogaster (S2). 2006. 124p. Tese (Doutorado). Programa de pós-graduação interunidades em Biotecnologia USP/Instituto Butantan/IPT. 2006.

YOKOMIZO A.Y.; JORGE S.A.C.; ASTRAY R.M.; FERNANDES I.; RIBEIRO O.G.; HORTON D.S.P.; TONSO A.; TORDO N.; PEREIRA C.A. Rabies virus glycoprotein expression in Drosophila S2 cells I. Functional recombinant protein in stable cotransfected cell line. Biotechnol. J. v.2, p.102-109, 2007. 


\section{APÊNDICE A - Cálculo da pressão média no interior da membrana de silicone}

\section{- Ensaio 1:}

P é a pressão no interior da membrana: média logarítmica para efeito de transferência de oxigênio.

$P_{E}$ é a pressão absoluta na entrada do tubo de silicone.

$P_{S}$ é a pressão absoluta na saída do tubo de silicone.

○ Sobrepressão de 0,4 bar (até o $7^{\circ}$ dia de cultivo)

$\mathrm{P}_{\mathrm{E}}$ é a sobrepressão na entrada do tubo de silicone (medida com manômetro) $=0,45$ bar.

P's é a sobrepressão na saída do tubo de silicone (medida com manômetro) $=0,40$ bar.

$P_{\text {atm }}$ é a pressão atmosférica média em São Paulo $=0,921$ bar

Portanto: $\left\{\begin{array}{l}P_{E}=P_{a t m}+P_{E}^{\prime}=0,921+0,45=1,371 \text { bar } \\ P_{S}=P_{a t m}+P_{S}^{\prime}=0,921+0,40=1,321 \text { bar }\end{array}\right.$

Fazendo a média logarítmica:

$$
P=\frac{P_{E}-P_{S}}{\ln \frac{P_{E}}{P_{S}}}=\frac{1,371-1,321}{\ln \frac{1,371}{1,321}} \Rightarrow P=1,346 \text { bar }
$$

\section{Assim, $\mathbf{P}=1,35$ bar}

- Sobrepressão de 1 bar (a partir do $7^{\circ}$ dia de cultivo)

P'E é a sobrepressão na entrada do tubo de silicone (medida com manômetro) $=1,05$ bar.

P's é a sobrepressão na saída do tubo de silicone (medida com manômetro) $=1,00$ bar.

$P_{\text {atm }}$ é a pressão atmosférica média em São Paulo $=0,921$ bar 
Portanto: $\left\{\begin{array}{l}P_{E}=P_{a t m}+P^{\prime}{ }_{E}=0,921+1,05=1,971 \text { bar } \\ P_{S}=P_{a t m}+P^{\prime}=0,921+1,00=1,921 \text { bar }\end{array}\right.$

Fazendo a média logarítmica:

$$
P=\frac{P_{E}-P_{S}}{\ln \frac{P_{E}}{P_{S}}}=\frac{1,971-1,921}{\ln \frac{1,971}{1,921}} \Rightarrow P=1,946 \quad \text { bar }
$$

\section{Assim, $\mathbf{P}=1,95$ bar}

\section{- Ensaio 2 até o Ensaio 6:}

$P^{\prime}$ é a sobrepressão na entrada do tubo de silicone (medida com manômetro) $=$ 0,55 bar.

P's é a sobrepressão na saída do tubo de silicone (medida com manômetro) $=$ 0,50 bar.

$P_{\mathrm{atm}}$ é a pressão atmosférica média em São Paulo $=0,921$ bar

Portanto: $\left\{\begin{array}{l}P_{E}=P_{a t m}+P^{\prime}=0,921+0,55=1,471 \mathrm{bar} \\ P_{S}=P_{a t m}+P^{\prime}{ }_{S}=0,921+0,50=1,421 \mathrm{bar}\end{array}\right.$

Fazendo a média logarítmica:

$$
P=\frac{P_{E}-P_{S}}{\ln \frac{P_{E}}{P_{S}}}=\frac{1,471-1,421}{\ln \frac{1,471}{1,421}} \Rightarrow P=1,446 \quad \text { bar }
$$

Assim, $P=1,45$ bar 


\section{APÊNDICE B - Cálculo da Constante de Henry para meio de cultura SF900 II}

$\begin{array}{ll}\text { Segundo Schumpe (1986): } & H=H_{\text {igua }}-\sum_{i=1}^{n} H_{i} \\ & \text { onde }: H_{i}=\left(\operatorname{conc}_{i} \times \operatorname{coef}_{i}\right)\end{array}$

Onde: $\mathrm{i}$ = cada soluto; conc $_{\mathrm{i}}=$ concentração de soluto; coef $_{\mathrm{i}}=$ coeficiente do soluto (tabelado em Schumpe, 1986).

A Constante de Henry $(\mathrm{H})$ depende dos solutos existentes no meio e da temperatura. $\mathrm{H}_{\text {água }}$ a $28^{\circ} \mathrm{C}$ a $700 \mathrm{mmHg}$, segundo U.S. Geological Survey (2007):

Portanto: $\quad \mathrm{H}_{\text {água }}=7,2 \mathrm{mg} \mathrm{O}_{2} /(\mathrm{L} . \mathrm{mmHg})$ ou $\mathrm{H}_{\text {água }}=\mathbf{3 7 , 2 2} \mathrm{mg} \mathrm{O}_{2} /($ L.atm $)$

Como não se tem a composição do Sf900 II isento de soro fetal bovino (formulação desconhecida), foi feita uma análise com o meio TC-100 de formulação conhecida, acrescida de glicose para $9 \mathrm{~g} / \mathrm{L}$ a $28^{\circ} \mathrm{C}$.

Cálculo dos $\mathrm{H}_{\mathrm{i}}$ :

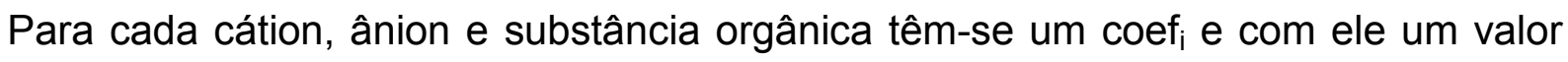
de $\mathrm{H}$ relacionado que deve ser contabilizado para cada molécula das substâncias formando um valor de $\mathrm{H}_{\mathrm{i}}$ conforme abaixo:

- Cloreto de Cálcio $\left(\mathrm{CaCl}_{2}\right)$ - concentração no meio TC-100 = 0,9966 g/L

$$
\begin{aligned}
& \mathrm{Ca}^{+}+2 \mathrm{Cl}^{-}=-0,3113+2(0,853)=1,3949 \mathrm{~L} / \mathrm{mol} \\
& \mathrm{Mol}=40+2(35,5)=111 \mathrm{~g} / \mathrm{mol} \\
& \mathrm{H}_{\mathrm{i}}=(0,9966: 111) 1,4010=0,0125
\end{aligned}
$$

- Cloreto de Magnésio $\left(\mathrm{MgCl}_{2}\right)$ - concentração no meio TC-100 = 1,0682 g/L

$\mathrm{Mg}^{+}+2 \mathrm{Cl}^{-}=-0,3050+2(0,853)=1,4010 \mathrm{~L} / \mathrm{mol}$

$\mathrm{Mol}=24+2(35,5)=95 \mathrm{~g} / \mathrm{mol}$

$H_{i}=(1,0682: 95) 1,4010=0,0158$

- Sulfato de Magnésio $\left(\mathrm{MgSO}_{4}\right)$ - concentração no meio TC-100 = 1,3579 g/L $\mathrm{Mg}^{+}+\mathrm{SO}_{4}{ }^{-}=-0,3050+0,4560=0,1510 \mathrm{~L} / \mathrm{mol}$

$\mathrm{Mol}=24+32+4(16)=120 \mathrm{~g} / \mathrm{mol}$ 
$H_{i}=(1,3579: 120) 0,1510=0,0017$

- Cloreto de Potássio $(\mathrm{KCl})$ - concentração no meio TC-100 = 2,87 g/L

$\mathrm{K}^{+}+\mathrm{Cl}^{-}=-0,5840+0,853=0,2690 \mathrm{~L} / \mathrm{mol}$

$\mathrm{Mol}=39+35,5=74,5 \mathrm{~g} / \mathrm{L}$

$H_{i}=(2,87: 74,5) 0,2690=0,0104$

- Bicarbonato de Sódio $\left(\mathrm{NaHCO}_{3}\right)$ - concentração no meio TC-100 = 0,35 g/L

$\mathrm{Na}^{+}+\mathrm{HCO}_{3}^{-}=-0,598+1,0043=04063 \mathrm{~L} / \mathrm{mol}$

$\mathrm{Mol}=23+1+12+3(16)=84 \mathrm{~g} / \mathrm{L}$

$H_{i}=(0,35: 84) 0,4063=0,0017$

- Fosfato de Sódio $\left(\mathrm{Na}_{3} \mathrm{PO}_{4}\right)$ - concentração no meio TC-100 = 0,8769 g/L

$3 \mathrm{Na}^{+}+\mathrm{PO}_{4}^{-3}=3(-0,598)+0,398=1,3960 \mathrm{~L} / \mathrm{mol}$

$\mathrm{Mol}=3(23)+31+4(16)=164 \mathrm{~g} / \mathrm{L}$

$H_{i}=(0,8769: 164) 1,3960=0,0075$

- Cisteína - concentração no meio TC-100 = 2,85 g/L

$H_{i}=\left(22,82 \cdot 10^{-4}\right) 2,85=0,0065$

- Glicina - concentração no meio TC-100 = 3,275 g/L

$H_{i}=\left(12,46.10^{-4}\right) 3,275=0,0041$

- Lisina - concentração no meio TC-100 = 2,172 g/L

$H_{i}=\left(13,45.10^{-4}\right) 2,172=0,0029$

- Glicose - concentração no meio TC-100 = 9 g/L

$H_{i}=\left(11,87.10^{-4}\right) 9=0,0107$

Assim, na Tabela 10 tem-se os solutos contabilizados (cátions, ânions e compostos orgânicos) para o cálculo da constante de Henry, segundo Schumpe (1986): 
Tabela 10 - Coeficientes para cálculo da Constante de Henry

\begin{tabular}{ccc} 
Soluto & Concentração em TC-100 & $\mathrm{H}_{\mathrm{i}}\left(\mathbf{m g}^{\mathrm{L}} \mathrm{L}^{-1} \cdot \mathbf{a t m}^{-1}\right)$ \\
\hline Cloreto de Cálcio & $0,9966 \mathrm{~g} / \mathrm{L}$ & 0,0125 \\
Cloreto de Magnésio & $1,0682 \mathrm{~g} / \mathrm{L}$ & 0,0158 \\
Sulfato de Magnésio & $1,3579 \mathrm{~g} / \mathrm{L}$ & 0,0017 \\
Cloreto de Potássio & $2,8702 \mathrm{~g} / \mathrm{L}$ & 0,0104 \\
Bicarbonato de Sódio & $0,3501 \mathrm{~g} / \mathrm{L}$ & 0,0017 \\
Fosfato de Sódio & $0,8769 \mathrm{~g} / \mathrm{L}$ & 0,0075 \\
Cisteína & $2,8500 \mathrm{~g} / \mathrm{L}$ & 0,0065 \\
Glicina & $3,2750 \mathrm{~g} / \mathrm{L}$ & 0,0041 \\
Lisina & $2,1720 \mathrm{~g} / \mathrm{L}$ & 0,0029 \\
Glicose & $9 \mathrm{~g} / \mathrm{L}$ & 0,0107 \\
& & 0,0738
\end{tabular}

Portanto: $\quad \begin{aligned} & H=H_{\text {agua }}-\sum_{i=1}^{n} H_{i} \\ & H=37,22-0,0738\end{aligned}$

Assim: $\mathbf{H}=37,15 \mathrm{mg} \mathrm{O} /($ L.atm) 


\section{APÊNDICE C - Cálculo do oxigênio dissolvido em meio de cultura SF900 II}

Oxigênio dissolvido (OD) é a porcentagem de oxigênio dissolvido na cultura, lido através do eletrodo de oxigênio calibrado na saturação com ar.

Assim, quando se fala em $100 \%$ de OD, isso significa que se tem o máximo de OD no meio, porém a fração de oxigênio no ar é de $21 \%$.

Sabendo-se a Constante de Henry (aproximada para o meio), a fração de $\mathrm{O}_{2}$ no ar e a pressão atmosférica a que se está trabalhando, tem-se que a concentração de oxigênio dissolvido na cultura é:

$$
\begin{aligned}
& C=H_{\text {meio }} \times P_{a t m} \times x_{O_{2}} \\
& C=37,15 \times \frac{700}{760} \times 0,21 \\
& C=7,19 \frac{m g O_{2}}{L}
\end{aligned}
$$

Assim, a cada $1 \mathrm{~L}$ de meio de cultura SF900II isento de soro fetal bovino a $28^{\circ} \mathrm{C}$ e $700 \mathrm{mmHg}$, o máximo que se consegue dissolver de oxigênio é $7,19 \mathrm{mg}$, o que corresponde aos $100 \%$ de OD. 


\section{APÊNDICE D - Medida de OUR, $k_{\mathrm{L}}$ a e Qo2 do Ensaio 1 (Sf9)}

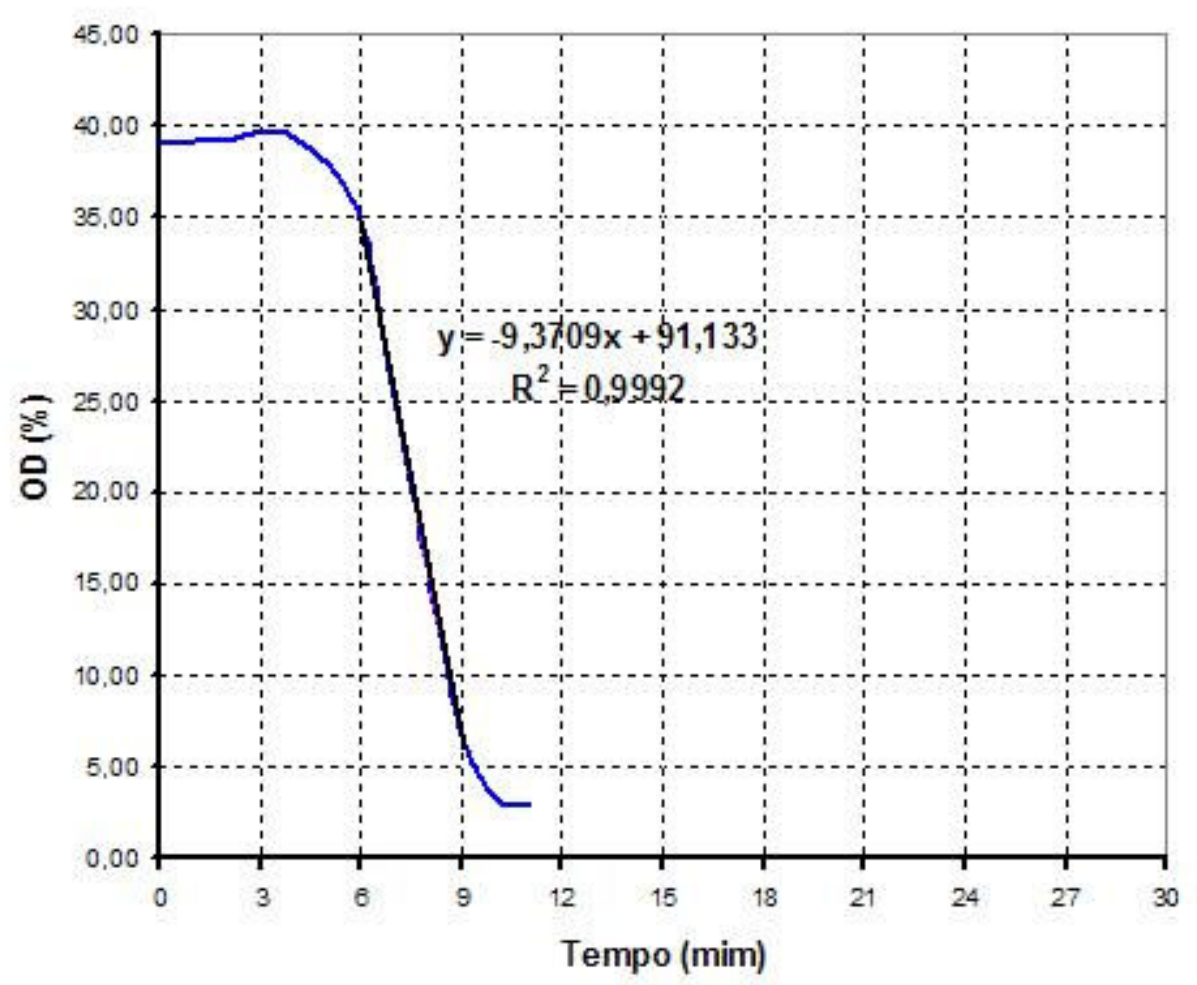

Gráfico A1 - Medida da OUR no Ensaio 1 (Sf9) no instante 6,3 dias.

Os dados são obtidos de minuto em minuto, porém para não causar uma poluição visual e poder-se enxergar melhor a curva, retirou-se os pontos em todos os gráficos de medida de OUR deste trabalho.

Este Método Dinâmico foi medido através do método tradicional, ou seja, foi desligada a aeração (válvula de $\mathrm{O}_{2}$ ) em $\mathrm{t}=2 \mathrm{~min}$. No $\mathrm{t}=3 \mathrm{~min}$., foi desligada a válvula de $\mathrm{N}_{2}$ e a agitação. Em $\mathrm{t}=10 \mathrm{~min}$ foi religada a agitação e retomada a aeração para voltar o controle de OD a $40 \%$.

Como visto na seção 3.2.1 e no Apêndice $C$, a quantidade máxima que se consegue dissolver de oxigênio em 1 litro de meio de cultura Sf900 II isento de soro fetal bovino é de 7,19 mg. Assim, 100\% de OD correspondem a 7,19 $\mathrm{mg} \mathrm{O}_{2}$ dissolvidos por cada litro de cultura. Conforme visto na seção 2.11, a OUR é igual ao coeficiente angular do trecho descendente do gráfico. Portanto, o coeficiente angular do gráfico A1 é de 9,371\%OD/min.

$$
\text { OUR }=\frac{(\text { Coef } \cdot \text { ang. }) \% O D}{100 \cdot \min } \times \frac{7,19 m g O_{2}}{L} \times \frac{1 \mathrm{mmol}}{32 m g} \times \frac{60 \mathrm{~min}}{1 \mathrm{~h}}
$$




\section{Assim, OUR = 1,26 $\mathrm{mmol} \mathrm{O}_{2} /($ L.h $)$}

Para o cálculo do kıa, utiliza-se a equação (6) vista na seção 2.11:

$$
k_{L} a=\frac{Q_{O_{2}} X}{\left(C_{S}-C_{0}\right)}=\frac{O U R}{\left(C_{S}-C_{0}\right)}
$$

Em $\left(C_{s}-C_{0}\right), C_{0}$ é a concentração de oxigênio no líquido e $C_{s}$ a concentração de oxigênio no líquido que está em equilíbrio com o gás de aeração, que na hora da medição da OUR foram de: $\mathrm{C}_{\mathrm{s}}=30,992 \mathrm{mgO}_{2} / \mathrm{L} \mathrm{e} \mathrm{C}_{0}=2,831 \mathrm{mgO}_{2} / \mathrm{L}$.

$$
k_{L} a=\frac{O U R}{\left(C_{S}-C_{0}\right)}=\frac{(\text { coef.ang. }) \% O D}{100 \cdot \min } \times \frac{60 \mathrm{~min}}{1 h} \times \frac{7,19 m g O 2}{L} \times \frac{L}{\left(C_{S}-C_{0}\right) m g O_{2}}
$$

Portanto, $k_{L} a=1,44 h^{-1}$

Lembrando-se que o $\mathrm{k}_{\mathrm{L}}$ a fixo deste sistema no Ensaio 1 foi considerado como sendo $1,40 \mathrm{~h}^{-1}$, conforme seção 3.5.1.

O Qo2 foi medido através da equação (2) vista na seção 2.11 e na concentração celular de $4,70.10^{6} \mathrm{cel} / \mathrm{mL}$.

$$
Q_{O_{2}}=\frac{(\text { coef.ang. }) \% O D}{100 . \min } \times \frac{7,19 m g}{L} \times \frac{1 m^{2} O_{2}}{32 g} \times \frac{1 g}{1000 m g} \times \frac{1 \mathrm{~min}}{60 s} \times \frac{1 L}{1000 m L} \times \frac{m L}{\text { Xcel }}
$$

Assim, $Q_{02}=7,47 \cdot 10^{-17}=74,7 \cdot 10^{-18} \mathrm{~mol} \mathrm{O}_{2} /($ cel.s $)$ 


\section{APÊNDICE E - Medida de OUR, $k_{L} a$ e Qo2 do Ensaio 2 (S2a)}

Utilizando as equações (A7), (A9) e (A10), temos para cada Método Dinâmico efetuado:

- $1^{\circ}$ Método Dinâmico (Método Tradicional - fechou-se a aeração (válvula de $\mathrm{O}_{2}$ ) em $\mathrm{t}=2$ min., manteve-se a linha pressurizada, desligou-se a válvula de $\mathrm{N}_{2}$ e a agitação após 1 minuto ( $\mathrm{t}=3$ min.). Religou-se, em $\mathrm{t}=9$ min., a aeração e a agitação).

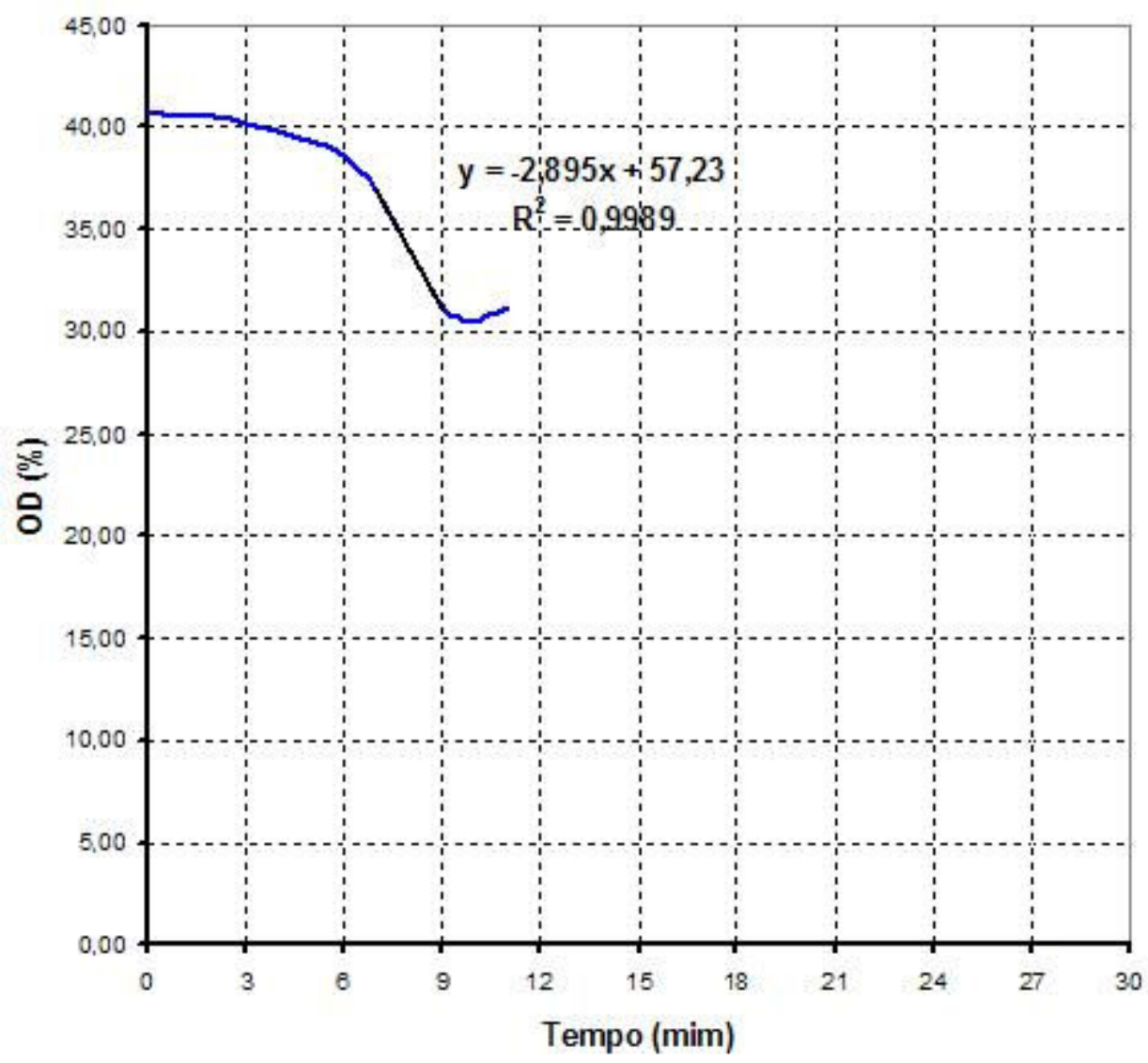

Gráfico A2 $-1^{\mathrm{a}}$ medida da OUR no Ensaio 2 (S2a) no instante 2,85 dias.

O coeficiente angular do gráfico A2 é de 2,895 OD (\%)/min.

Assim, OUR $=0,39 \mathrm{mmol} \mathrm{O}_{2} /($ L.h $)$

Nesta OUR tem-se: $\mathrm{C}_{\mathrm{s}}=21,952 \mathrm{mgO}_{2} / \mathrm{L}$ e $\mathrm{C}_{0}=2,893 \mathrm{mgO}_{2} / \mathrm{L}$.

Portanto, $k_{L} \mathbf{a}=0,66 h^{-1}$ 
Lembrando-se que o $\mathrm{k}$ a fixo deste sistema a partir do Ensaio 2 foi considerado como sendo $1,18 \pm 0,06 \mathrm{~h}^{-1}$, conforme seção 3.5.1.

Com uma concentração celular de $16,8.10^{6} \mathrm{cel} / \mathrm{mL}$

Assim, $Q_{02}=6,45.10^{-18} \mathrm{~mol} \mathrm{O}_{2} /$ (cel.s)

- $2^{\circ}$ Método Dinâmico (Método Tradicional - fechou-se a aeração (válvula de $\mathrm{O}_{2}$ ) em $\mathrm{t}=0$ min., manteve-se a linha pressurizada, desligou-se a válvula de $\mathrm{N}_{2}$ e a agitação após 1 minuto ( $\mathrm{t}=1 \mathrm{~min}$.). Religou-se, em $\mathrm{t}=7 \mathrm{~min}$., a aeração e a agitação).

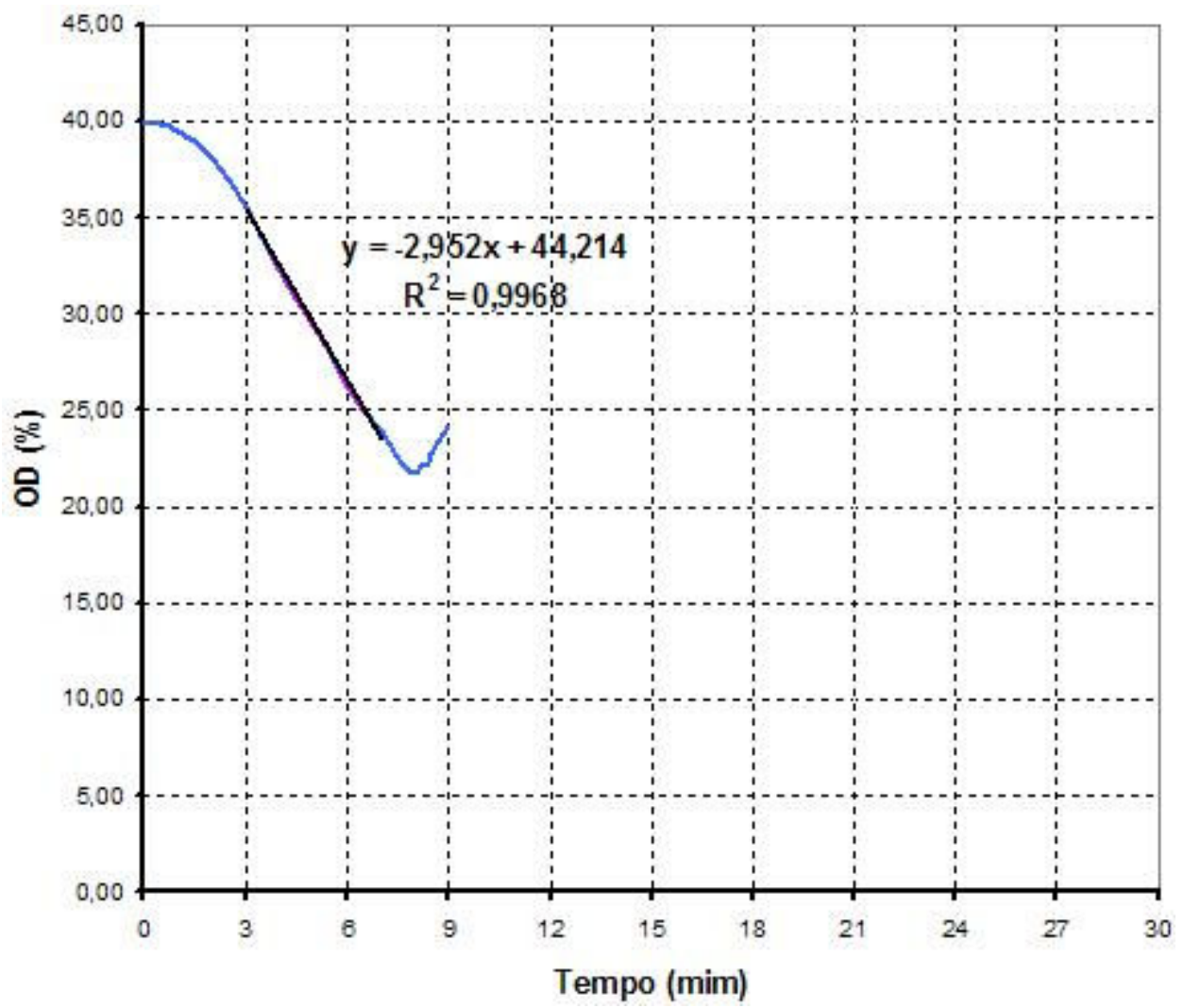

Gráfico A3 - $2^{\mathrm{a}}$ medida da OUR no Ensaio 2 (S2a) no instante 3,58 dias.

O coeficiente angular do gráfico A3 é de 2,952 OD (\%)/min.

Assim, OUR $=0,40 \mathrm{mmol} \mathrm{O}_{2} /($ L.h $)$

Nesta OUR tem-se: $\mathrm{C}_{\mathrm{s}}=21,952 \mathrm{mgO}_{2} / \mathrm{L} \mathrm{e} \mathrm{C}_{0}=2,877 \mathrm{mgO}_{2} / \mathrm{L}$.

Portanto, $\mathbf{k}_{\mathrm{L}} \mathbf{a}=\mathbf{0 , 6 7} \mathrm{h}^{-1}$ 
Com uma concentração celular de $20,0.10^{6} \mathrm{cel} / \mathrm{mL}$

Assim, $Q_{02}=5,53.10^{-18} \mathrm{~mol} \mathrm{O}_{2} /($ cel.s $)$

- $3^{\circ}$ Método Dinâmico (Método Tradicional - fechou-se a aeração (válvula de $\mathrm{O}_{2}$ ) em $\mathrm{t}=2$ min., manteve-se a linha pressurizada, desligou-se a válvula de $\mathrm{N}_{2}$ e a agitação após 1 minuto ( $\mathrm{t}=3 \mathrm{~min}$.). Religou-se, em $\mathrm{t}=9 \mathrm{~min}$., $a$ aeração e a agitação. Porém, desta vez, foi desligada, junto com a válvula de $\mathrm{O}_{2}$, a ação e retomada quando religada a aeração).

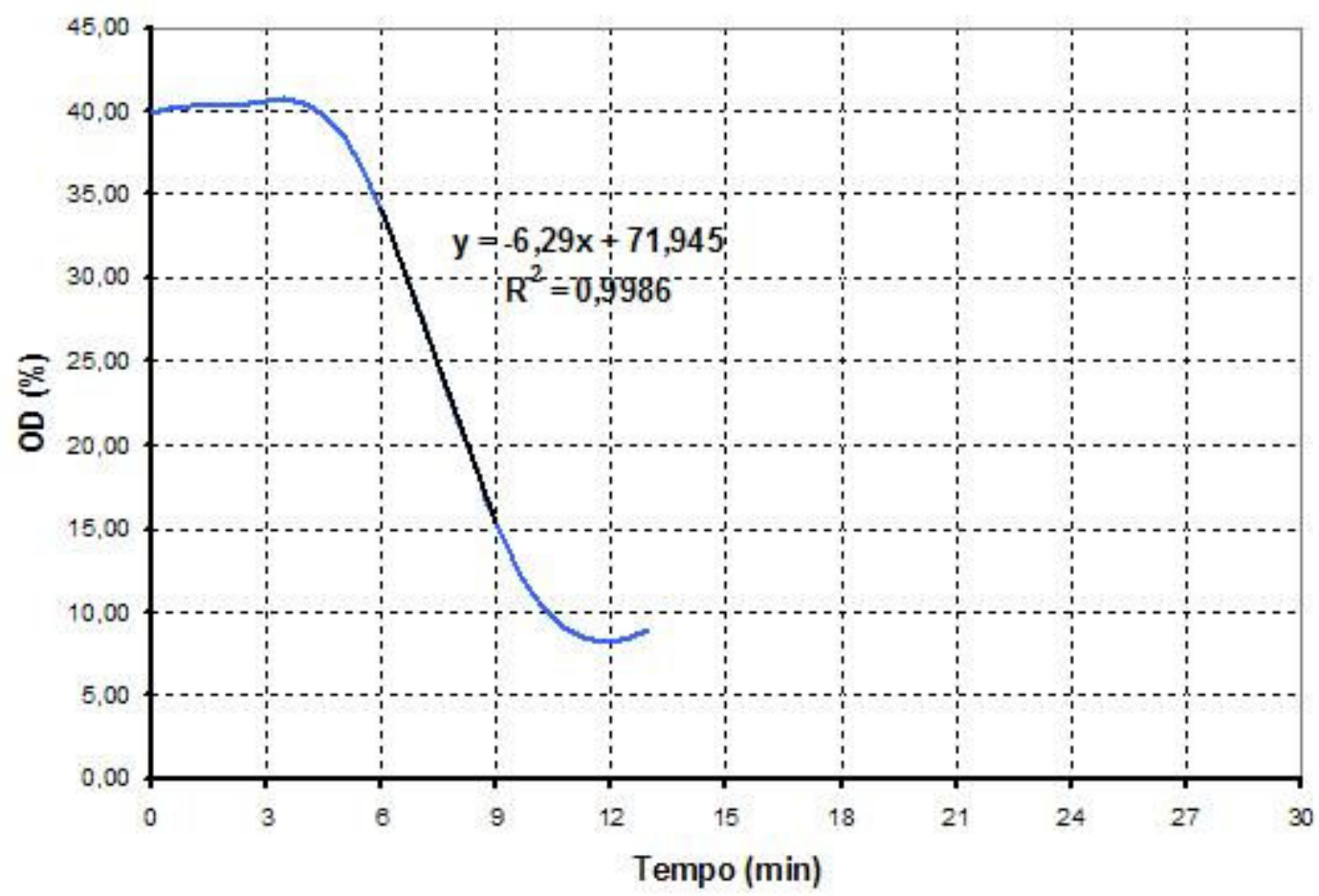

Gráfico A4 - $3^{\mathrm{a}}$ medida da OUR no Ensaio 2 (S2a) no instante 7,91 dias.

O coeficiente angular do gráfico A4 é de 6,290 OD (\%)/min.

Assim, OUR = 0,85 $\mathrm{mmol} \mathrm{O}_{2} /($ L.h $)$

Nesta OUR tem-se: $\mathrm{C}_{\mathrm{s}}=19,370 \mathrm{mgO}_{2} / \mathrm{L}$ e $\mathrm{C}_{0}=2,847 \mathrm{mgO}_{2} / \mathrm{L}$.

Portanto, $k_{L} \mathbf{a}=1,64 h^{-1}$

Com uma concentração celular de $44,8.10^{6} \mathrm{cel} / \mathrm{mL}$

Assim, $Q_{02}=5,26.10^{-18} \mathrm{~mol} \mathrm{O}_{2} /$ (cel.s) 


\section{APÊNDICE F - Medida de OUR, $k_{\mathrm{L}} a$ e Qo2 do Ensaio 3 (S2b)}

Utilizando as equações (A7), (A9) e (A10), temos para cada Método Dinâmico efetuado:

- $1^{\circ}$ Método Dinâmico (Método Tradicional - fecha a aeração (válvula de $\mathrm{O}_{2}$ ) e a ação em $t=2$ min., manteve-se a linha pressurizada, desligou-se a válvula de $\mathrm{N}_{2}$ e a agitação após 1 minuto ( $\mathrm{t}=3 \mathrm{~min}$.). Religou-se, em $\mathrm{t}=25 \mathrm{~min}$., a ação, aeração e a agitação). O $\mathrm{C}_{\text {crit }}$ está indicado no Gráfico A5.

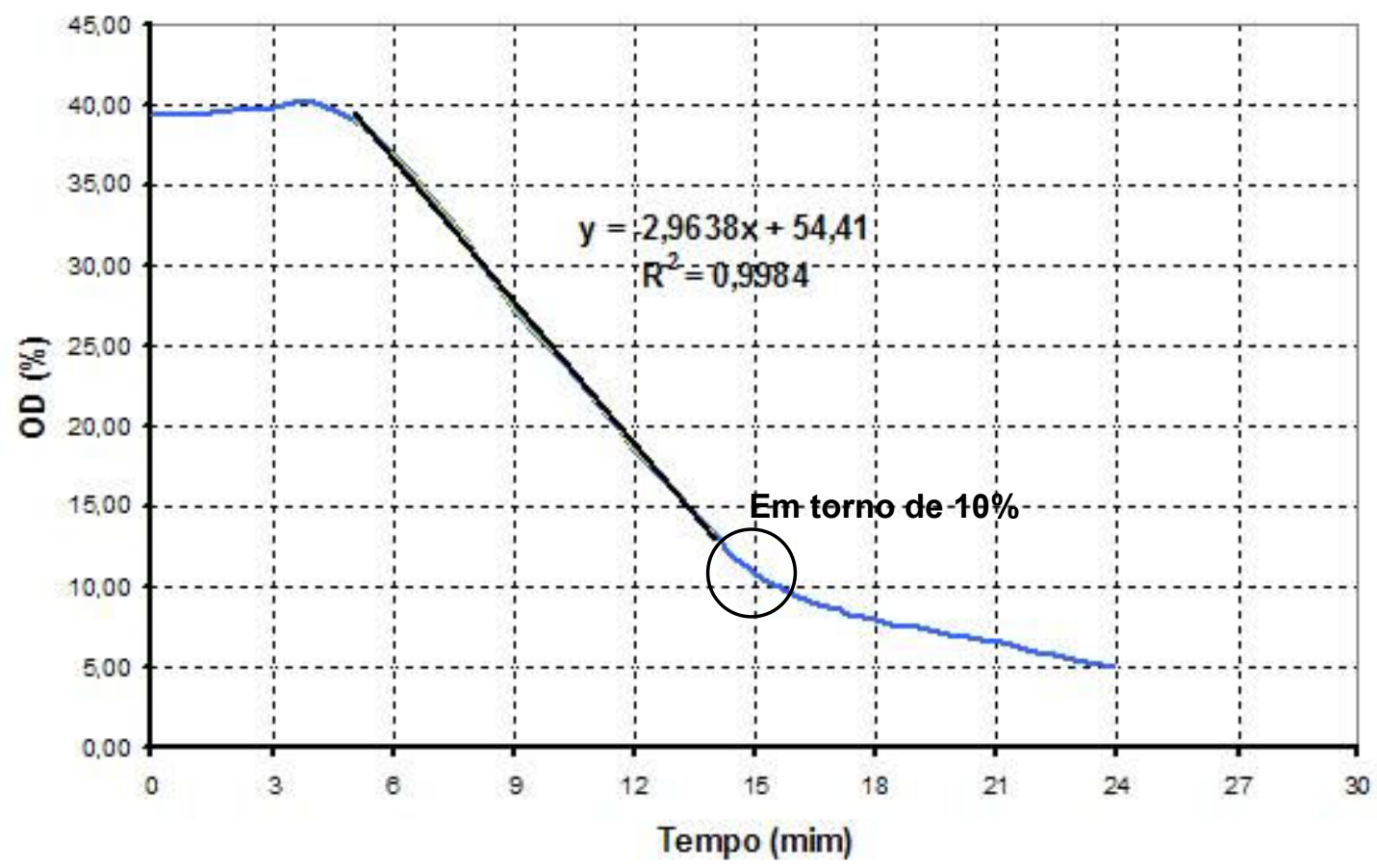

Gráfico A5 - $1^{\text {a }}$ medida da OUR no Ensaio $3(\mathrm{~S} 2 \mathrm{~b})$ no instante 3,26 dias.

O coeficiente angular do gráfico A5 é de 2,964 OD (\%)/min.

Assim, OUR $=0,40 \mathrm{mmol} \mathrm{O}_{2} /($ L.h $)$

Nesta OUR tem-se: $\mathrm{C}_{\mathrm{s}}=23,857 \mathrm{mgO}_{2} / \mathrm{L} \mathrm{e} \mathrm{C}_{0}=2,813 \mathrm{mgO}_{2} / \mathrm{L}$.

Portanto, $\mathbf{k}_{\mathrm{L}} \mathbf{a}=\mathbf{0 , 6 1} \mathrm{h}^{-1}$

Com uma concentração celular de $33,0.10^{6} \mathrm{cel} / \mathrm{mL}$

Assim, $Q_{02}=3,36.10^{-18} \mathrm{~mol} \mathrm{O}_{2} /($ cel.s $)$ 
- $2^{\circ}$ Método Dinâmico (Método Tradicional - fecha a aeração (válvula de $\mathrm{O}_{2}$ ) e a ação em t = 2 min., despressurizou-se a linha, desligou-se a válvula de $\mathrm{N}_{2} \mathrm{e}$ a agitação após 1 minuto ( $\mathrm{t}=3 \mathrm{~min}$.). Religou-se, em $\mathrm{t}=23 \mathrm{~min}$., a ação, aeração e a agitação e pressurizou-se a linha). $O \mathrm{C}_{\text {crit }}$ está indicado no Gráfico A6.

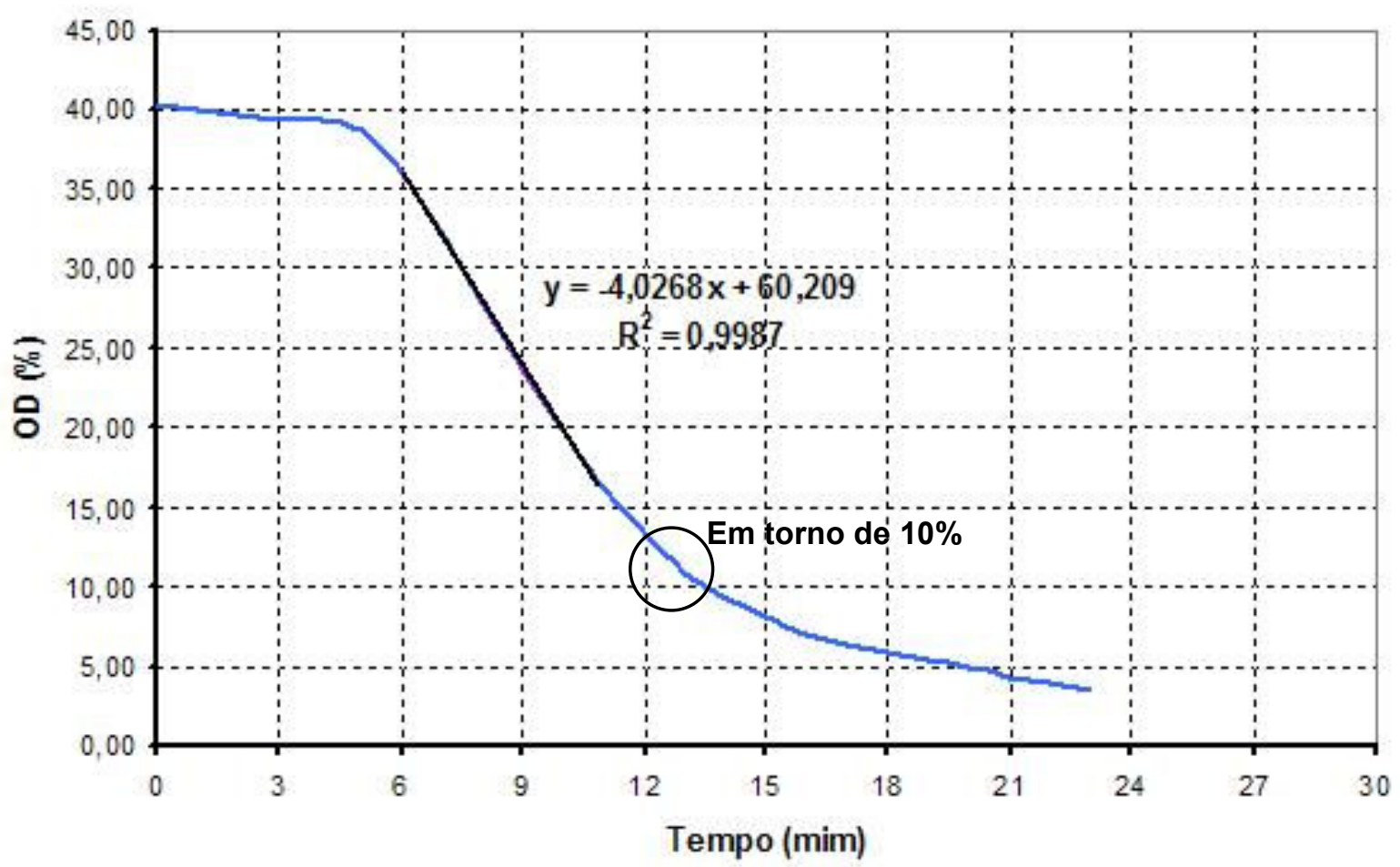

Gráfico A6 - 2a medida da OUR no Ensaio 3 (S2b) no instante 4,32 dias.

O coeficiente angular do gráfico A6 é de 4,027 OD (\%)/min.

Assim, OUR = 0,54 $\mathrm{mmol} \mathrm{O}_{2} /($ L.h $)$

Nesta OUR tem-se: $\mathrm{C}_{\mathrm{s}}=27,624 \mathrm{mgO}_{2} / \mathrm{L} \mathrm{e} \mathrm{C}_{0}=2,820 \mathrm{mgO}_{2} / \mathrm{L}$.

Portanto, $\mathbf{k}_{\mathrm{L}} \mathbf{a}=\mathbf{0 , 7 0} \mathbf{h}^{-1}$

Com uma concentração celular de $45,8 \cdot 10^{6} \mathrm{cel} / \mathrm{mL}$

Assim, $Q_{02}=3,29.10^{-18} \mathrm{~mol} \mathrm{O}_{2} /$ (cel.s) 
- $3^{\circ}$ Método Dinâmico (Método Tradicional - fecha a aeração (válvula de $\mathrm{O}_{2}$ ) e a ação em $\mathrm{t}=2$ min., manteve-se a linha pressurizada, desligou-se a válvula de $\mathrm{N}_{2}$ e a agitação após 1 minuto ( $\mathrm{t}=3 \mathrm{~min}$.). Religou-se, em $\mathrm{t}=29 \mathrm{~min}$., a ação, aeração e a agitação). $O \mathrm{C}_{\text {crit }}$ está indicado no Gráfico A7.

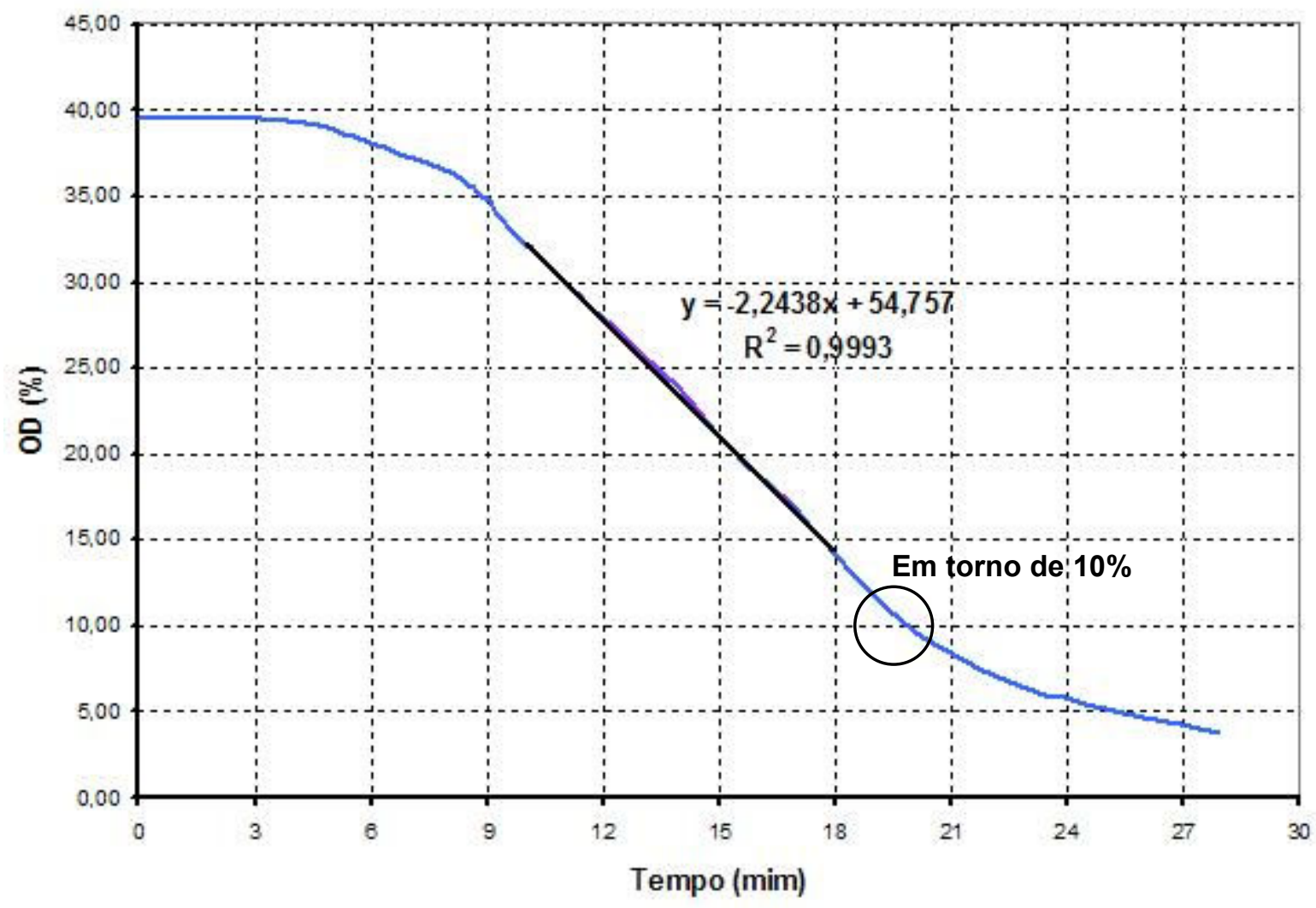

Gráfico A7 - $3^{\mathrm{a}}$ medida da OUR no Ensaio 3 (S2b) no instante 6,06 dias.

O coeficiente angular do gráfico A7 é de 2,244 OD (\%)/min.

Assim, OUR $=\mathbf{0 , 3 0 ~} \mathrm{mmol}_{2} /($ L.h $)$

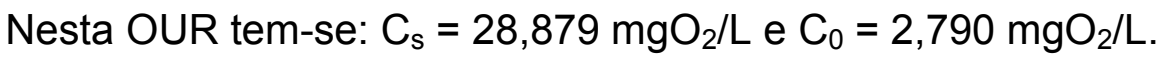

Portanto, $\mathbf{k}_{\mathrm{L}} \mathbf{a}=\mathbf{0} \mathbf{0} \mathbf{3 7} \mathrm{h}^{-1}$

Com uma concentração celular de $29,0.10^{6} \mathrm{cel} / \mathrm{mL}$

Assim, $Q_{02}=2,90.10^{-18} \mathrm{~mol} \mathrm{O}_{2} /($ cel.s) 


\section{APÊNDICE G - Medida de OUR, $k_{L} a$ e Qo2 do Ensaio 4 (S2AcGPV)}

Utilizando as equações (A7), (A9) e (A10), temos para cada Método Dinâmico efetuado:

- $1^{\circ}$ Método Dinâmico (Método Tradicional - fecha a aeração (válvula de $\mathrm{O}_{2}$ ) e a ação em $t=2$ min., manteve-se a linha pressurizada, desligou-se a válvula de $\mathrm{N}_{2}$ e a agitação após 1 minuto ( $\mathrm{t}=3 \mathrm{~min}$.). Religou-se, em $\mathrm{t}=15 \mathrm{~min}$., a ação, aeração e a agitação).

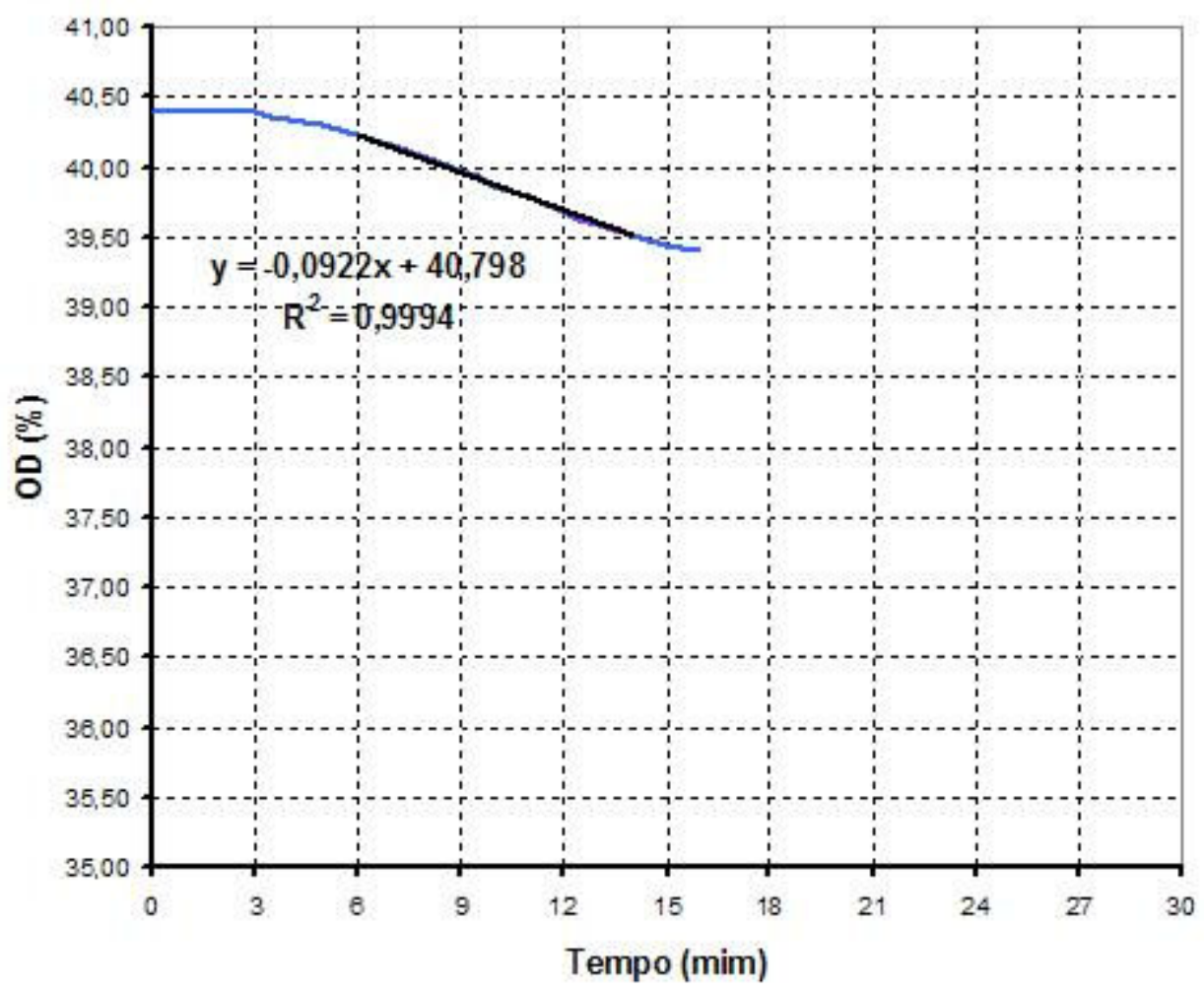

Gráfico A8 $-1^{\text {a }}$ medida da OUR no Ensaio 4 (GPV) no instante 2,87 dias. Este gráfico está em escala diferente dos demais para ter-se a possibilidade de melhor visualização.

O coeficiente angular do gráfico A8 é de 0,092 OD (\%)/min.

Assim, OUR = 0,01 $\mathrm{mmol} \mathrm{O}_{2} /($ L.h $)$

Nesta OUR tem-se: $\mathrm{C}_{\mathrm{s}}=6,278 \mathrm{mgO}_{2} / \mathrm{L} \mathrm{e} \mathrm{C}_{0}=2,829 \mathrm{mgO}_{2} / \mathrm{L}$.

Portanto, $\mathbf{k}_{\mathrm{L}} \mathbf{a}=\mathbf{0 , 1 2} \mathrm{h}^{-1}$

Com uma concentração celular de $0,94 \cdot 10^{6} \mathrm{cel} / \mathrm{mL}$

Assim, $Q_{02}=3,67.10^{-18} \mathrm{~mol} \mathrm{O}_{2} /$ (cel.s) 
- $\quad 2^{\circ}$ Método Dinâmico (Novo Método Proposto - desligada a agitação e a ação em $t$ = 4 min., e, partir daí, conforme o OD foi decaindo no meio de cultura, foi ajustado, para a mesma fração, o gás na cabeça do reator e na membrana de silicone, mantendo tudo em equilíbrio, sem transferência. Por exemplo, se o eletrodo de oxigênio que está no cultivo lê 39\% OD, então se faz passar $39 \%$ de ar na mistura gasosa que vai para a cabeça do reator e também na mistura gasosa que vai para a membrana de silicone, mantendo assim, o equilíbrio gasoso. Foi religada a agitação e a ação em $t=22 \min$. e retomada a aeração para controle a $40 \%$ OD).

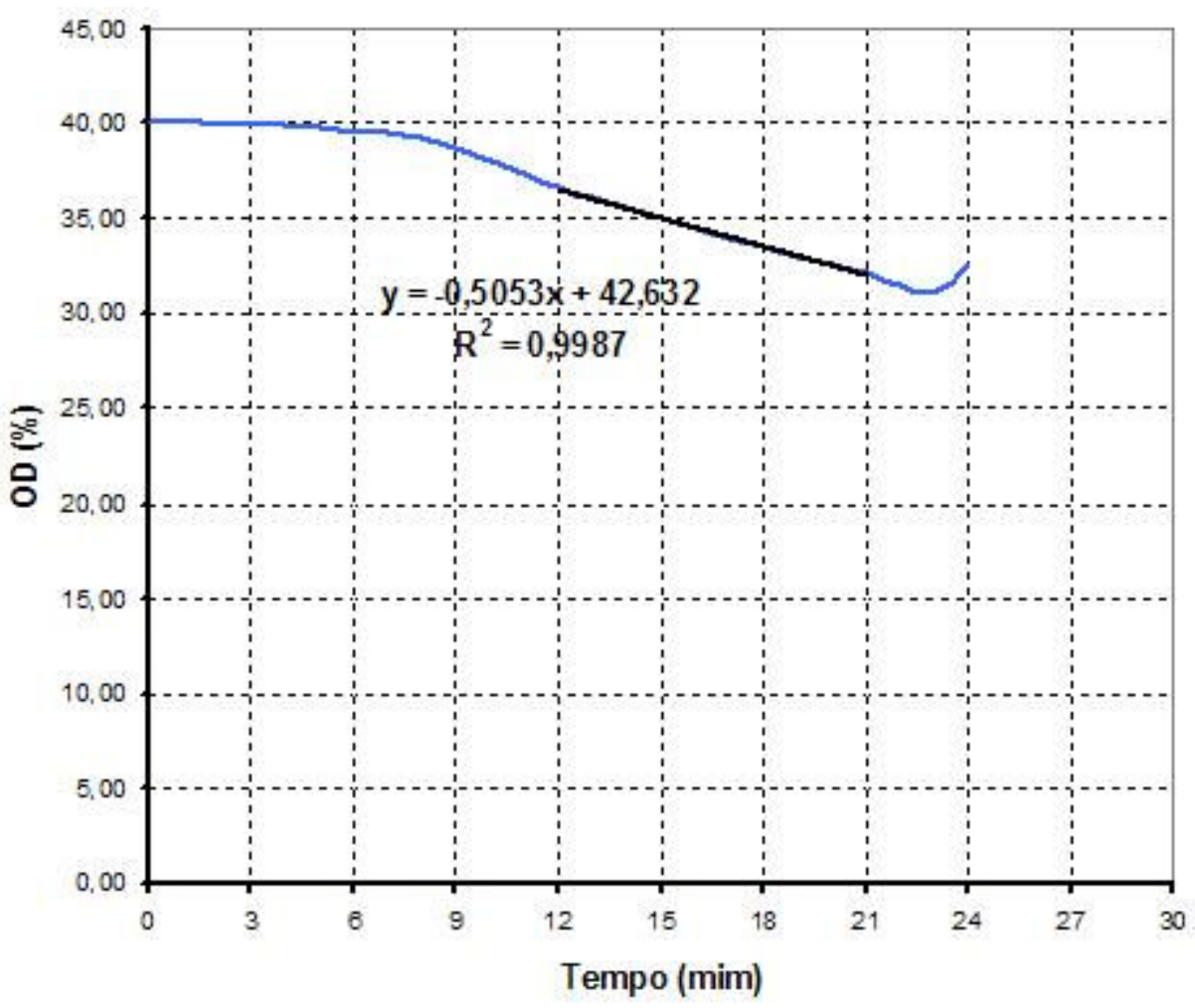

Gráfico A9 - $2^{\mathrm{a}}$ medida da OUR no Ensaio 4 (GPV) no instante 3,79 dias

O coeficiente angular do gráfico A9 é de 0,505 OD (\%)/min.

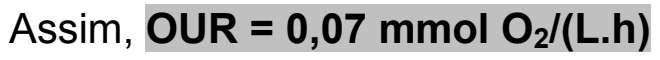

Nesta OUR tem-se: $\mathrm{C}_{\mathrm{s}}=10,045 \mathrm{mgO}_{2} / \mathrm{L}$ e $\mathrm{C}_{0}=2,792 \mathrm{mgO}_{2} / \mathrm{L}$.

Portanto, $\mathbf{k}_{\mathrm{L}} \mathbf{a}=\mathbf{0 , 3 0} \mathrm{h}^{-1}$

Com uma concentração celular de $2,41.10^{6} \mathrm{cel} / \mathrm{mL}$

Assim, $Q_{02}=7,85.10^{-18} \mathrm{~mol} \mathrm{O}_{2} /$ (cel.s) 
- $3^{\circ}$ Método Dinâmico (Método Tradicional - fecha a aeração (válvula de $\mathrm{O}_{2}$ ) e a ação em t = 1 min., despressurizou-se a linha, desligou-se a válvula de $\mathrm{N}_{2} \mathrm{e}$ a agitação após 1 minuto ( $t=2$ min.). Religou-se, em $t=27$ min., a ação, aeração e a agitação).

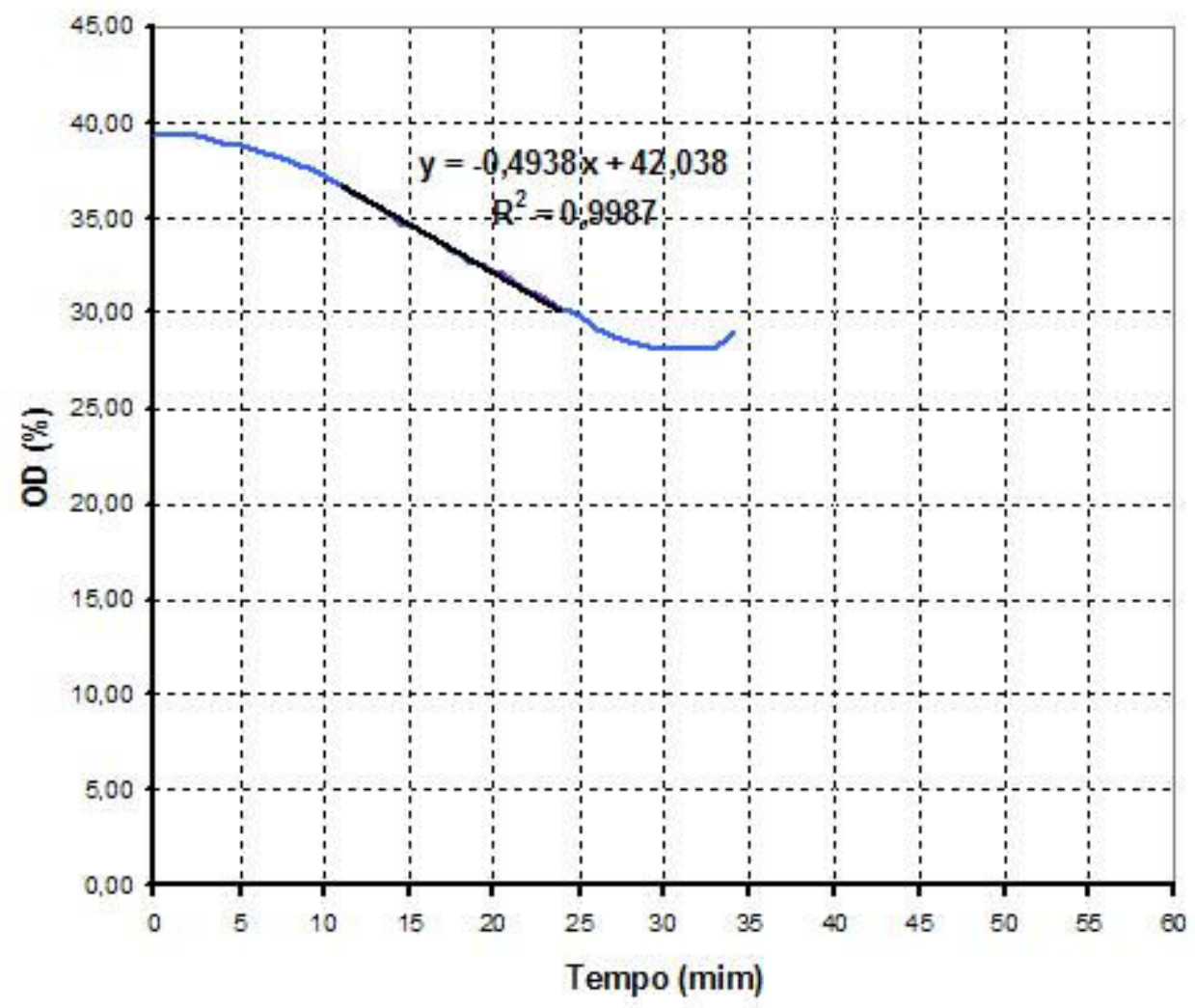

Gráfico A10 - 3a medida da OUR no Ensaio 4 (GPV) no instante 4,19 dias.

O coeficiente angular do gráfico A10 é de 0,494 OD (\%)/min.

Assim, OUR = 0,07 $\mathrm{mmol} \mathrm{O}_{2} /($ L.h $)$

Nesta OUR tem-se: $\mathrm{C}_{\mathrm{s}}=12,556 \mathrm{mgO}_{2} / \mathrm{L}$ e $\mathrm{C}_{0}=2,789 \mathrm{mgO}_{2} / \mathrm{L}$.

Portanto, $\mathbf{k}_{\mathrm{L}} \mathbf{a}=\mathbf{0 , 2 2} \mathbf{h}^{-1}$

Com uma concentração celular de $4,16.10^{6} \mathrm{cel} / \mathrm{mL}$

Assim, $Q_{02}=4,45.10^{-18} \mathrm{~mol} \mathrm{O}_{2} /$ (cel.s) 
- $4^{0}$ Método Dinâmico (Novo Método Proposto - desligada a agitação e a ação em $t$ = 1 min., e, partir daí, conforme o OD foi decaindo no meio de cultura, foi ajustado, para a mesma fração, o gás na cabeça do reator e na membrana de silicone, mantendo tudo em equilíbrio, sem transferência. Foi religada a agitação e a ação em $t=26$ min. e retomada a aeração para controle a $40 \%$ OD). O $\mathrm{C}_{\text {crit }}$ está indicado no Gráfico A11.

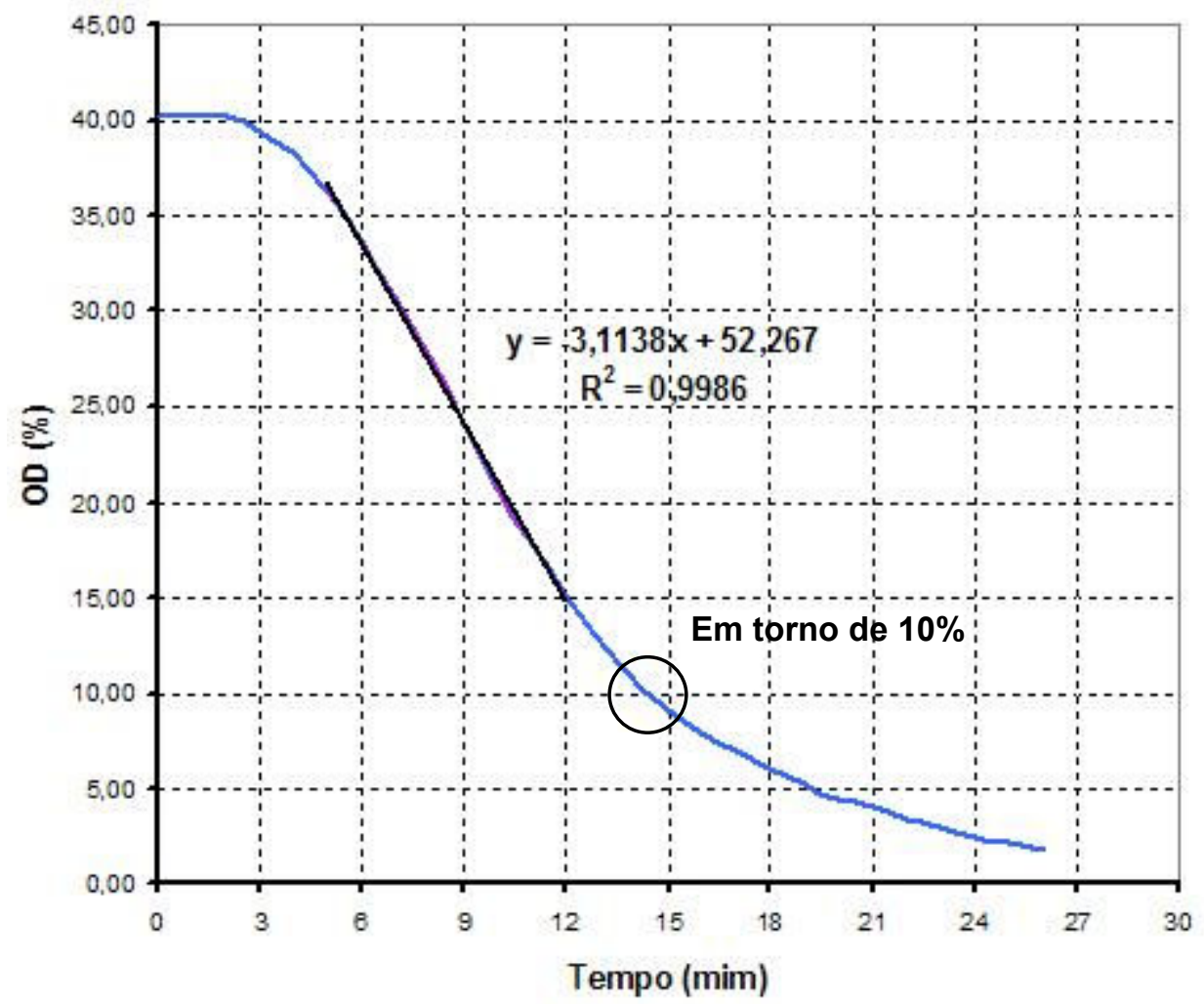

Gráfico A11 - 4ª medida da OUR no Ensaio 4 (GPV) no instante 4,79 dias.

O coeficiente angular do gráfico A11 é de 3,114 OD (\%)/min.

Assim, OUR = 0,43 $\mathrm{mmol} \mathrm{O}_{2} /($ L.h $)$

Nesta OUR tem-se: $\mathrm{C}_{\mathrm{s}}=17,579 \mathrm{mgO}_{2} / \mathrm{L} \mathrm{e} \mathrm{C}_{0}=2,782 \mathrm{mgO}_{2} / \mathrm{L}$.

Portanto, $\mathbf{k}_{\mathrm{L}} \mathbf{a}=\mathbf{0 , 9 1} \mathbf{h}^{-1}$

Com uma concentração celular de $7,68.10^{6} \mathrm{cel} / \mathrm{mL}$

Assim, $Q_{02}=15,18.10^{-18} \mathrm{~mol} \mathrm{O}_{2} /($ cel.s $)$ 
- $5^{\circ}$ Método Dinâmico (Método Tradicional - fecha a aeração (válvula de $\mathrm{O}_{2}$ ) e a ação em $\mathrm{t}=1$ min., manteve-se a linha pressurizada, desligou-se a válvula de $\mathrm{N}_{2}$ e a agitação após 1 minuto ( $\mathrm{t}=2 \mathrm{~min}$.). Religou-se, em $\mathrm{t}=15 \mathrm{~min}$., a ação, aeração e a agitação).

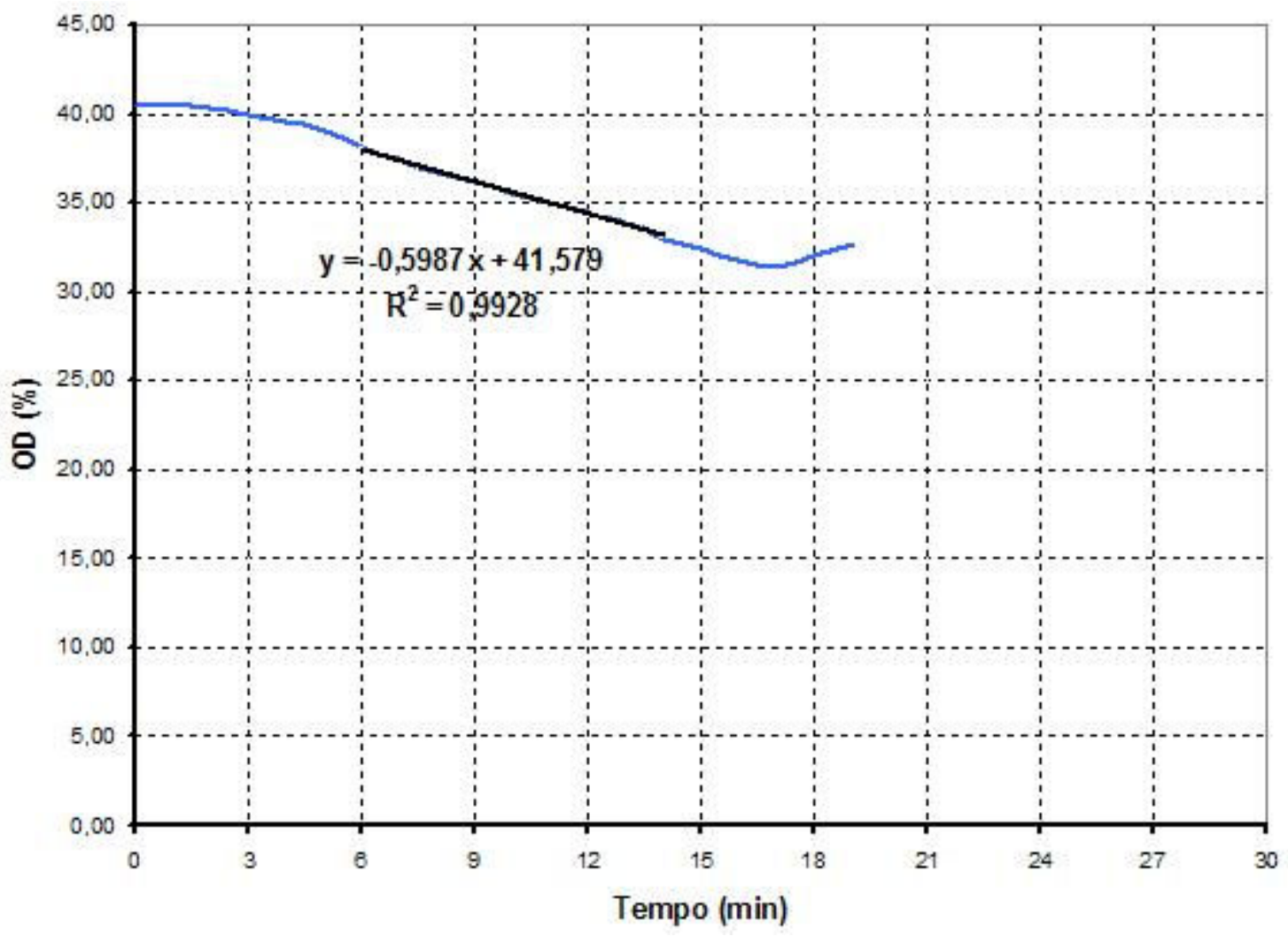

Gráfico A12 - 5a medida da OUR no Ensaio 4 (GPV) no instante 5,20 dias.

O coeficiente angular do gráfico A12 é de 0,599 OD (\%)/min.

Assim, OUR $=0,08 \mathrm{mmol} \mathrm{O}_{2} /($ L.h $)$

Nesta OUR tem-se: $\mathrm{C}_{\mathrm{s}}=21,346 \mathrm{mgO}_{2} / \mathrm{L}$ e $\mathrm{C}_{0}=2,839 \mathrm{mgO}_{2} / \mathrm{L}$.

Portanto, $\mathbf{k}_{\mathrm{L}} \mathbf{a}=\mathbf{0 , 1 4} \mathbf{h}^{-1}$

Com uma concentração celular de $10,68 \cdot 10^{6} \mathrm{cel} / \mathrm{mL}$

Assim, $Q_{02}=2,10.10^{-18} \mathrm{~mol} \mathrm{O}_{2} /$ (cel.s) 
- $6^{\circ}$ Método Dinâmico (Novo Método Proposto - desligada a agitação e a ação em $t$ = 1 min., e, partir daí, conforme o OD foi decaindo no meio de cultura, foi ajustado, para a mesma fração, o gás na cabeça do reator e na membrana de silicone, mantendo tudo em equilíbrio, sem transferência. Foi religada a agitação e a ação em $t=20$ min. e retomada a aeração para controle a $40 \%$ OD). O $\mathrm{C}_{\text {crit }}$ está indicado no Gráfico A13.

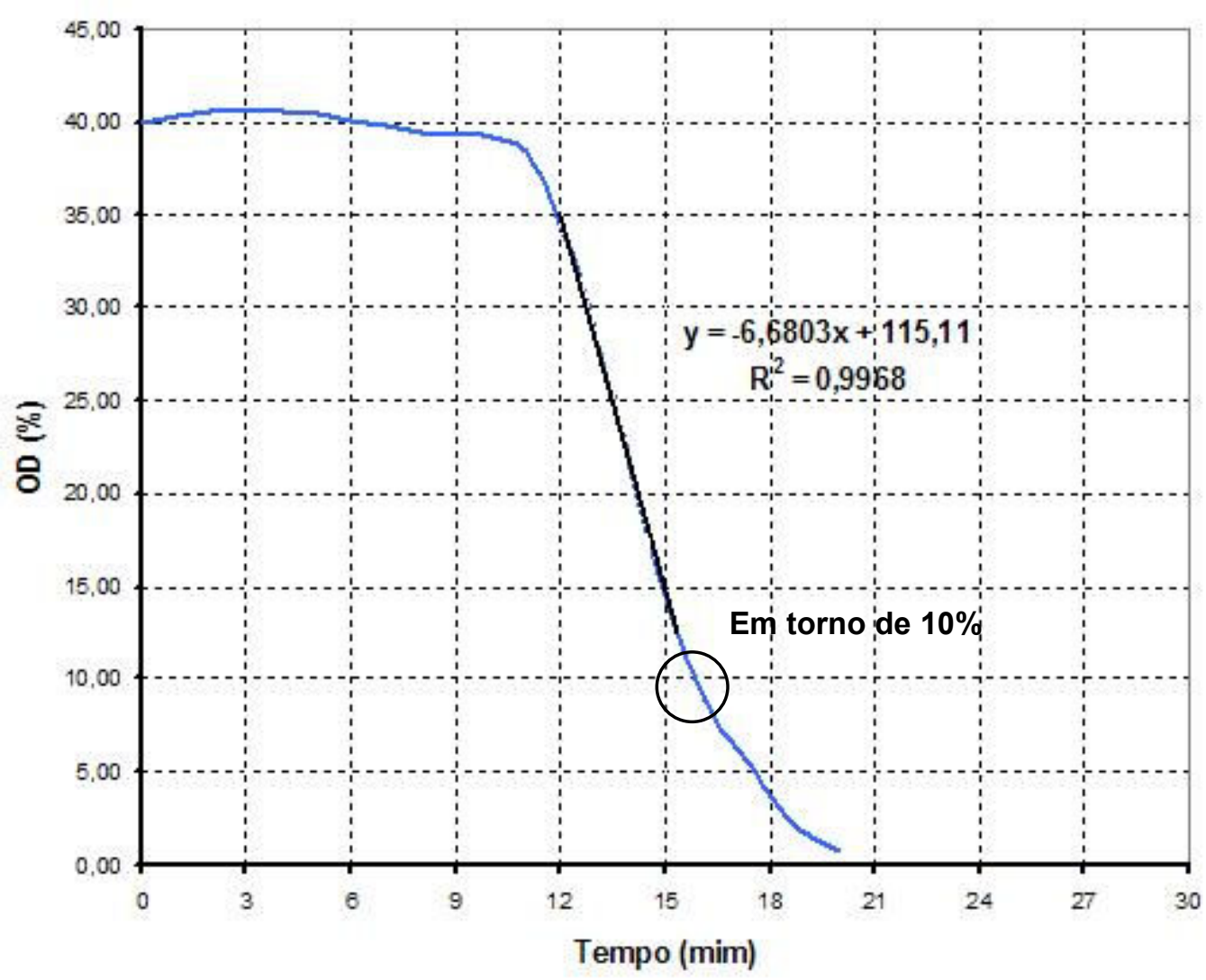

Gráfico A13 - 6a medida da OUR no Ensaio 4 (GPV) no instante 5,95 dias.

O coeficiente angular do gráfico A13 é de 6,680 OD (\%)/min.

Assim, OUR $=0,90 \mathrm{mmol} \mathrm{O}_{2} /($ L.h $)$

Nesta OUR tem-se: $\mathrm{C}_{\mathrm{s}}=23,857 \mathrm{mgO}_{2} / \mathrm{L} \mathrm{e} \mathrm{C}_{0}=2,842 \mathrm{mgO}_{2} / \mathrm{L}$.

Portanto, $k_{L} \mathbf{a}=1,37 h^{-1}$

Com uma concentração celular de $15,60.10^{6} \mathrm{cel} / \mathrm{mL}$

Assim, $Q_{02}=16,04 \cdot 10^{-18} \mathrm{~mol} \mathrm{O}_{2} /($ cel.s $)$ 
- $7^{\circ}$ Método Dinâmico (Método Tradicional - fecha a aeração (válvula de $\mathrm{O}_{2}$ ) e a ação em $t=4$ min., despressurizou-se a linha, desligou-se a válvula de $\mathrm{N}_{2} \mathrm{e}$ a agitação após 1 minuto ( $t=5$ min.). Religou-se, em $t=17$ min., a ação, aeração e a agitação. Mantido a 20\% OD desde a amostra anterior).

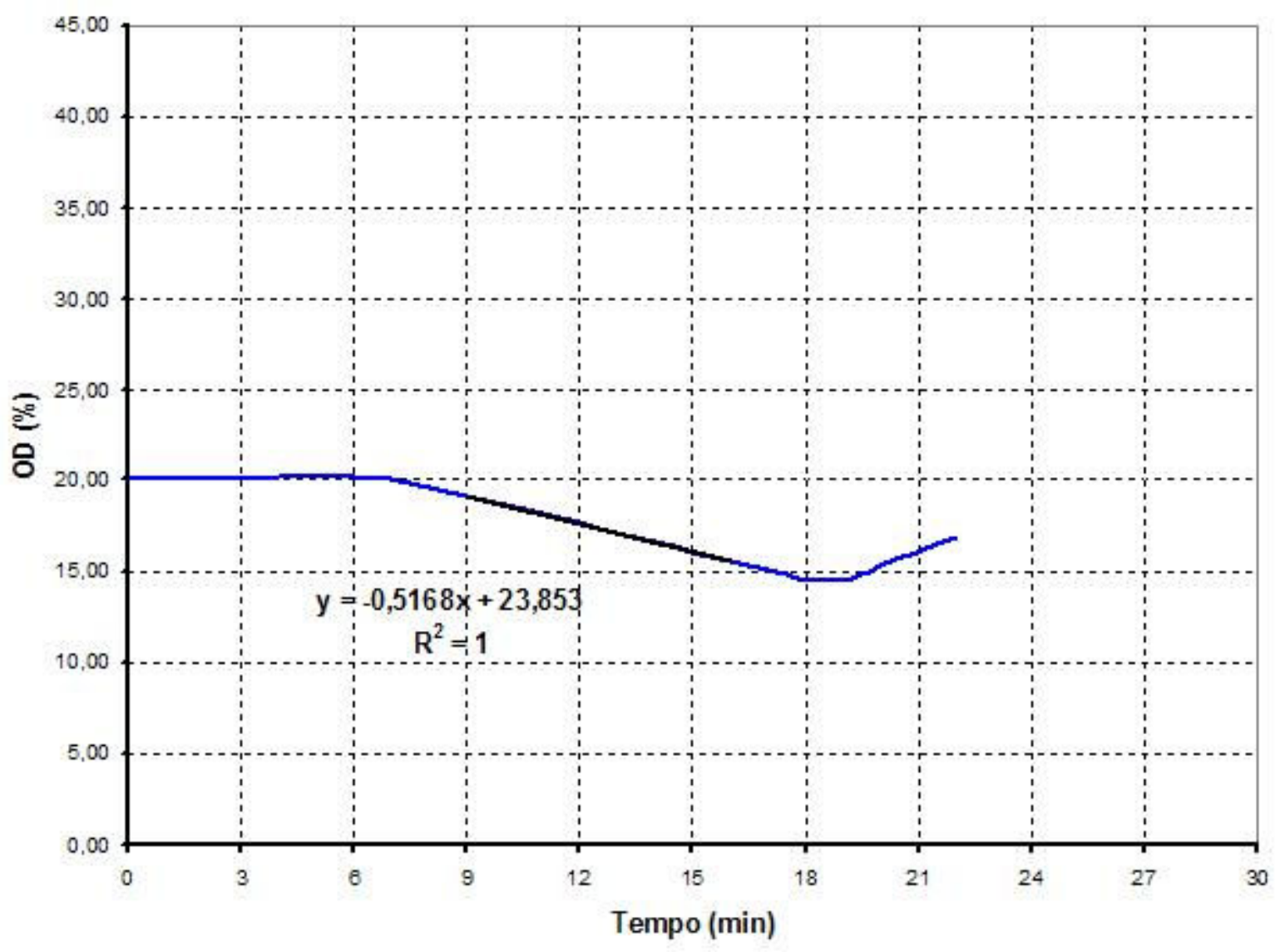

Gráfico A14 - $7^{\text {a }}$ medida da OUR no Ensaio 4 (GPV) no instante 6,29 dias.

O coeficiente angular do gráfico A14 é de 0,517 OD (\%)/min.

Assim, OUR = 0,07 $\mathrm{mmol} \mathrm{O}_{2} /($ L.h $)$

Nesta OUR tem-se: $\mathrm{C}_{\mathrm{s}}=25,113 \mathrm{mgO}_{2} / \mathrm{L}$ e $\mathrm{C}_{0}=1,398 \mathrm{mgO}_{2} / \mathrm{L}$.

Portanto, $\mathbf{k}_{\mathrm{L}} \mathbf{a}=0,09 \mathbf{h}^{-1}$

Com uma concentração celular de $19,60.10^{6} \mathrm{cel} / \mathrm{mL}$

Assim, $Q_{02}=0,99.10^{-18} \mathrm{~mol} \mathrm{O}_{2} /$ (cel.s) 
- $8^{\circ}$ Método Dinâmico (Novo Método Proposto - desligada a agitação e a ação em $t$ = 1 min., e, partir daí, conforme o OD foi decaindo no meio de cultura, foi ajustado, para a mesma fração, o gás na cabeça do reator e na membrana de silicone, mantendo tudo em equilíbrio, sem transferência. Foi religada a agitação e a ação em $t=17$ min. e retomada a aeração para controle a $40 \%$ OD). O $\mathrm{C}_{\text {crit }}$ está indicado no Gráfico A15.

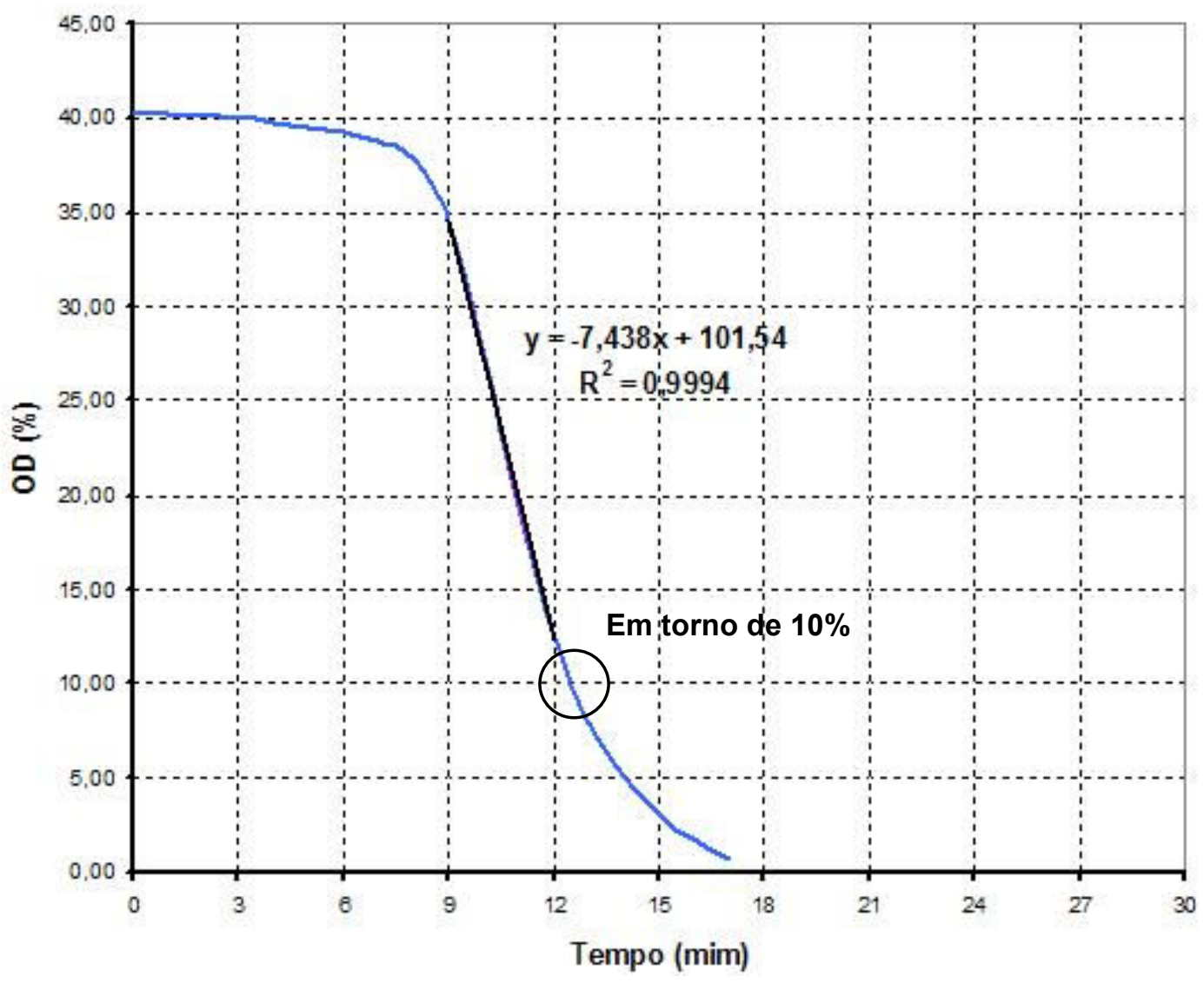

Gráfico A15 - 8a medida da OUR no Ensaio 4 (GPV) no instante 6,77 dias.

O coeficiente angular do gráfico A15 é de 7,438 OD (\%)/min.

Assim, OUR = 1,03 $\mathrm{mmol} \mathrm{O}_{2} /($ L.h $)$

Nesta OUR tem-se: $\mathrm{C}_{\mathrm{s}}=26,368 \mathrm{mgO}_{2} / \mathrm{L}$ e $\mathrm{C}_{0}=2,799 \mathrm{mgO}_{2} / \mathrm{L}$.

Portanto, $k_{\mathrm{L}} \mathbf{a}=1,36 \mathrm{~h}^{-1}$

Com uma concentração celular de $22,35 \cdot 10^{6} \mathrm{cel} / \mathrm{mL}$

Assim, $Q_{02}=12,46.10^{-18} \mathrm{~mol} \mathrm{O}_{2} /(\mathrm{cel} . \mathrm{s})$ 
- $9^{\circ}$ Método Dinâmico (Novo Método Proposto - desligada a agitação e a ação em $t$ = 1 min., e, partir daí, conforme o OD foi decaindo no meio de cultura, foi ajustado, para a mesma fração, o gás na cabeça do reator e na membrana de silicone, mantendo tudo em equilíbrio, sem transferência. Foi religada a agitação e a ação em $t=24$ min. e retomada a aeração para controle a $40 \%$ OD). O $\mathrm{C}_{\text {crit }}$ está indicado no Gráfico A16.

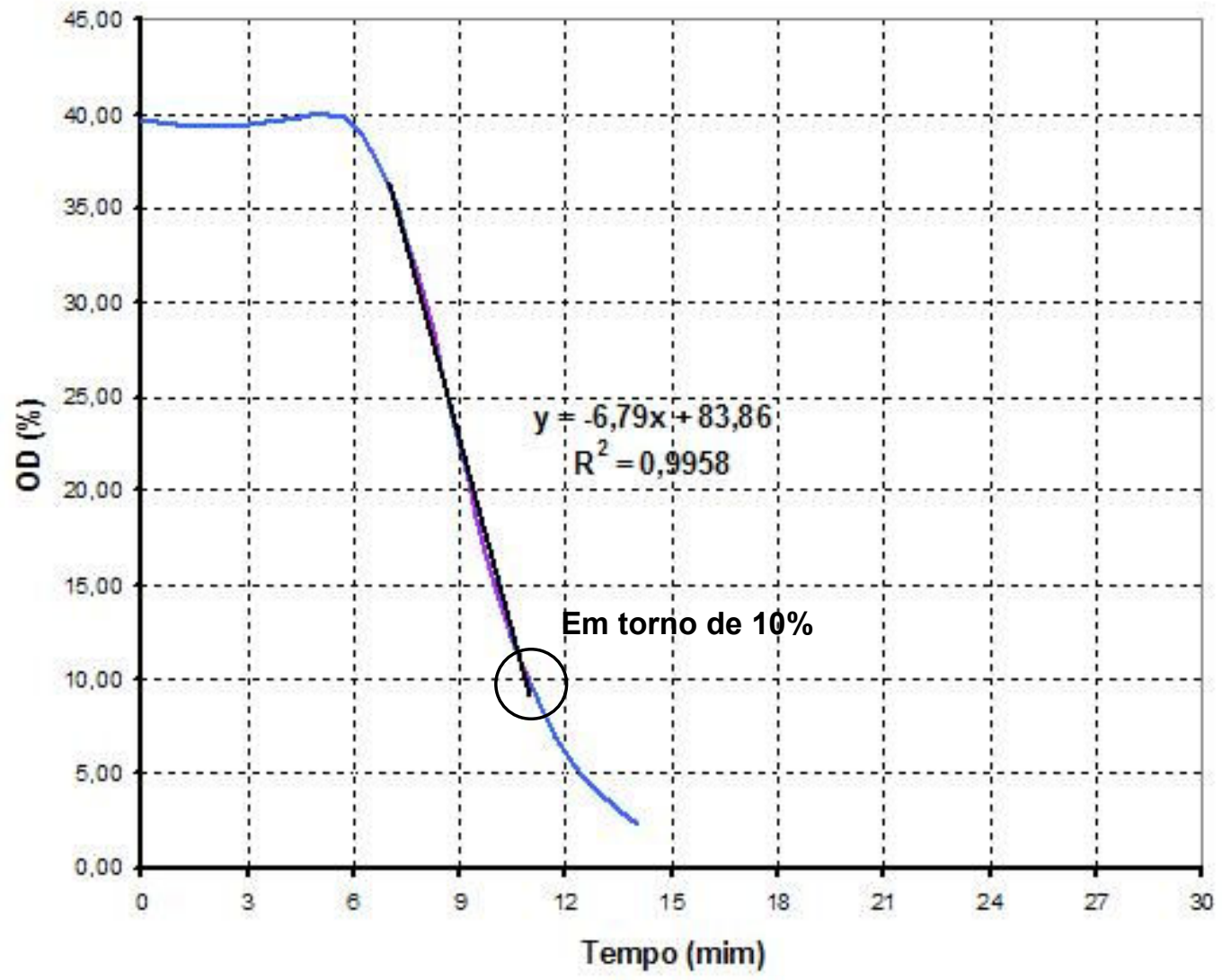

Gráfico A16 - 9a medida da OUR no Ensaio 4 (GPV) no instante 7,23 dias.

O coeficiente angular do gráfico A16 é de 6,790 OD (\%)/min.

Assim, OUR = 0,92 $\mathrm{mmol} \mathrm{O}_{2} /($ L.h $)$

Nesta OUR tem-se: $\mathrm{C}_{\mathrm{s}}=26,368 \mathrm{mgO}_{2} / \mathrm{L}$ e $\mathrm{C}_{0}=2,751 \mathrm{mgO}_{2} / \mathrm{L}$.

Portanto, $\mathbf{k}_{\mathrm{L}} \mathbf{a}=1,24 \mathrm{~h}^{-1}$

Com uma concentração celular de $24,86 \cdot 10^{6} \mathrm{cel} / \mathrm{mL}$

Assim, $Q_{02}=10,23 \cdot 10^{-18} \mathrm{~mol} \mathrm{O}_{2} /($ cel.s $)$ 
- $10^{\circ}$ Método Dinâmico (Método Tradicional - fecha a aeração (válvula de $\mathrm{O}_{2}$ ) e a ação em $\mathrm{t}=3$ min., despressurizou-se a linha, desligou-se a válvula de $\mathrm{N}_{2}$ e a agitação após 1 minuto ( $t=4$ min.). Religou-se, em $t=24$ min., a ação, aeração e a agitação).

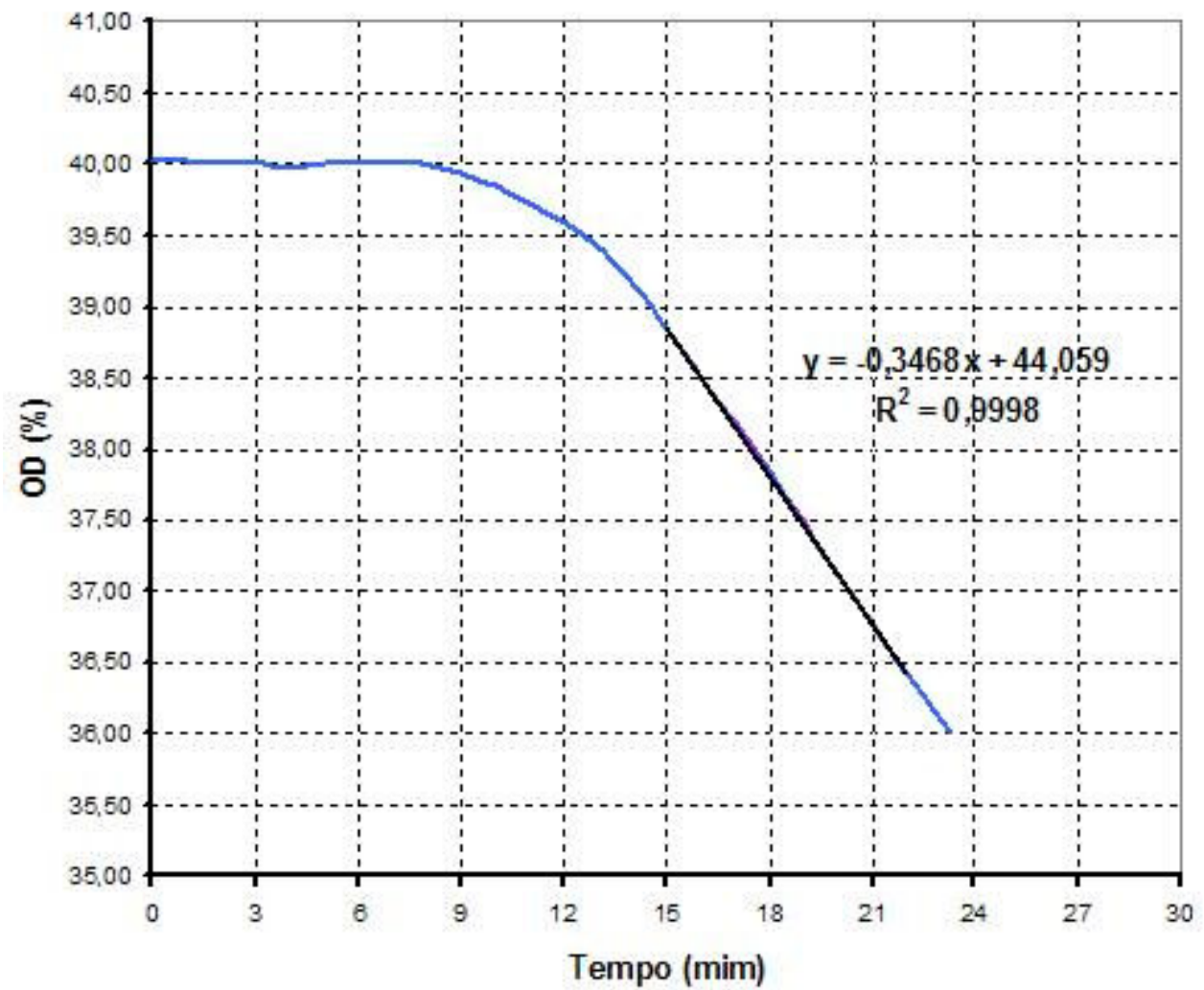

Gráfico A17 - 10ª medida da OUR no Ensaio 4 (GPV) no instante 7,79 dias. Este gráfico está em escala diferente dos demais para ter-se a possibilidade de melhor visualização.

O coeficiente angular do gráfico A17 é de 0,347 OD (\%)/min.

\section{Assim, OUR = 0,05 $\mathrm{mmol} \mathrm{O}_{2} /($ L.h $)$}

Nesta OUR tem-se: $\mathrm{C}_{\mathrm{s}}=26,368 \mathrm{mgO}_{2} / \mathrm{L} \mathrm{e} \mathrm{C}_{0}=2,758 \mathrm{mgO}_{2} / \mathrm{L}$.

Portanto, $\mathbf{k}_{\mathrm{L}} \mathbf{a}=\mathbf{0 , 0 6} \mathbf{h}^{-1}$

Com uma concentração celular de $26,60.10^{6} \mathrm{cel} / \mathrm{mL}$

Assim, $Q_{02}=4,88.10^{-19}=0,49.10^{-18} \mathrm{~mol} \mathrm{O}_{2} /($ cel.s $)$ 
- $11^{\circ}$ Método Dinâmico (Novo Método Proposto - desligada a agitação e a ação em $t$ = 2 min., e, partir daí, conforme o OD foi decaindo no meio de cultura, foi ajustado, para a mesma fração, o gás na cabeça do reator e na membrana de silicone, mantendo tudo em equilíbrio, sem transferência. Foi religada a agitação e a ação em $t=17$ min. e retomada a aeração para controle a 40\% OD). O C crit está indicado no Gráfico A18.

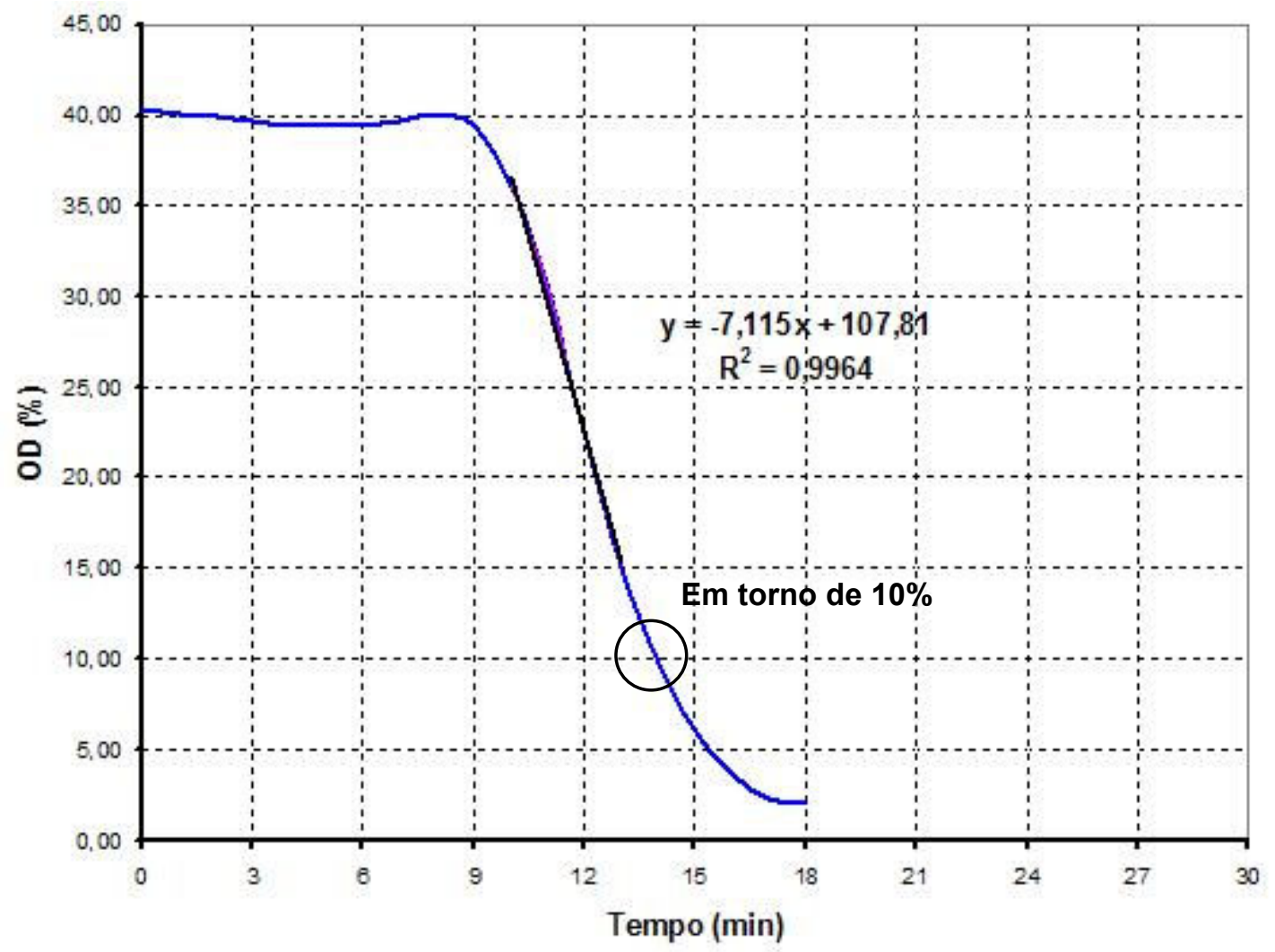

Gráfico A18 - 11ª medida da OUR no Ensaio 4 (GPV) no instante 8,25 dias.

O coeficiente angular do gráfico A18 é de 7,115 OD (\%)/min.

Assim, OUR = 0,96 $\mathrm{mmol} \mathrm{O}_{2} /($ L.h $)$

Nesta OUR tem-se: $\mathrm{C}_{\mathrm{s}}=23,857 \mathrm{mgO}_{2} / \mathrm{L}$ e $\mathrm{C}_{0}=2,813 \mathrm{mgO}_{2} / \mathrm{L}$.

Portanto, $k_{L} a=1,46 h^{-1}$

Com uma concentração celular de $24,72.10^{6} \mathrm{cel} / \mathrm{mL}$

Assim, $Q_{02}=10,78 \cdot 10^{-18} \mathrm{~mol} \mathrm{O}_{2} /($ cel.s $)$ 
- $12^{\circ}$ Método Dinâmico (Método Tradicional - fecha a aeração (válvula de $\mathrm{O}_{2}$ ) e a ação em $\mathrm{t}=2$ min., despressurizou-se a linha, desligou-se a válvula de $\mathrm{N}_{2}$ e a agitação após 1 minuto ( $t=3$ min.). Religou-se, em $t=90$ min., a ação, aeração e a agitação). Porém, este método foi medido após controle em $80 \%$ OD. O $\mathrm{C}_{\text {crit }}$ está indicado no Gráfico A19.

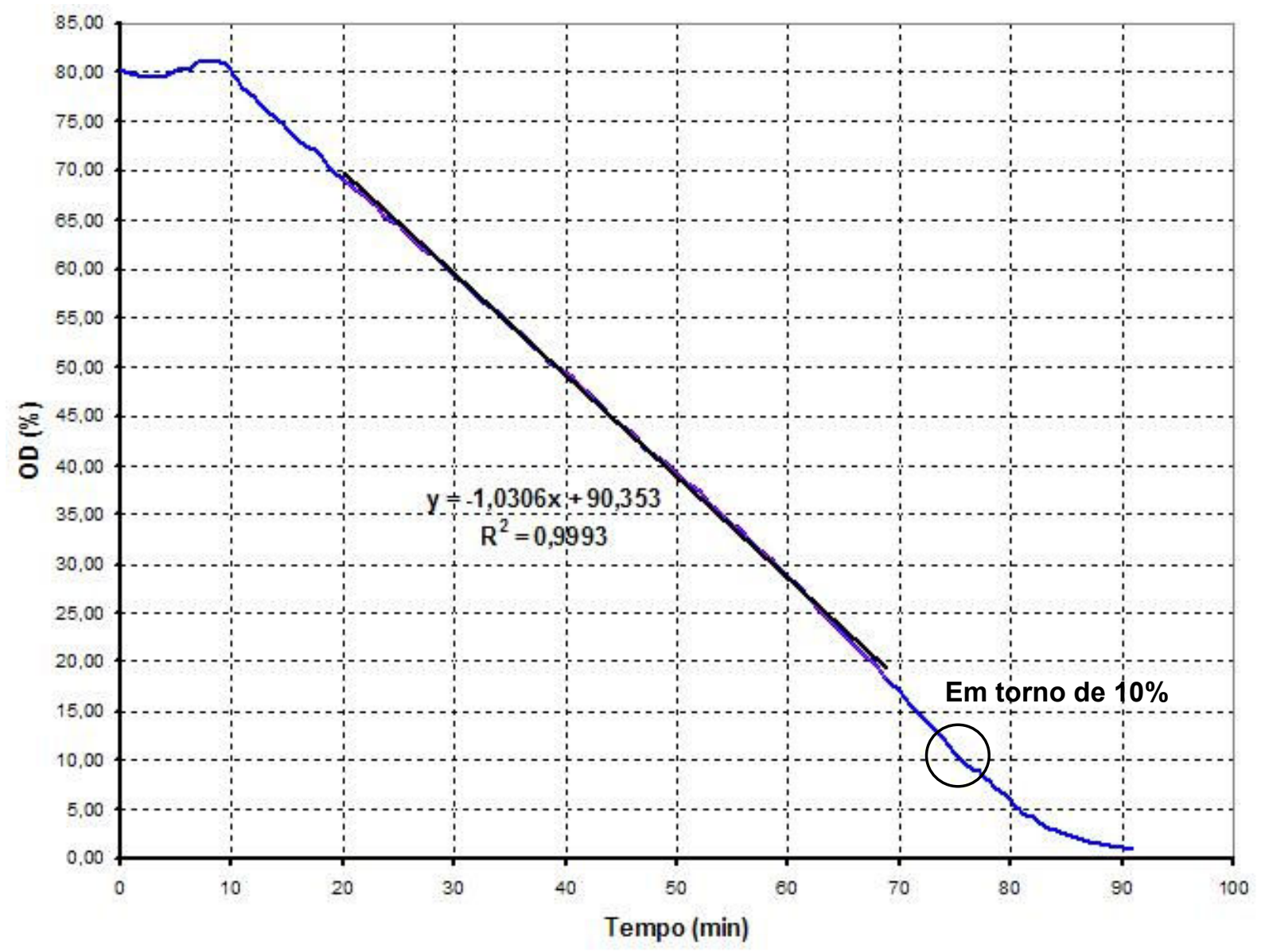

Gráfico A19 - 12 $2^{\mathrm{a}}$ medida da OUR no Ensaio 4 (GPV) no instante 8,91 dias.

O coeficiente angular do gráfico A19 é de 1,031 OD (\%)/min.

Assim, OUR $=0,14 \mathrm{mmol}_{2} /($ L.h $)$

Nesta OUR tem-se: $\mathrm{C}_{\mathrm{s}}=28,879 \mathrm{mgO}_{2} / \mathrm{L} \mathrm{e} \mathrm{C}_{0}=5,658 \mathrm{mgO}_{2} / \mathrm{L}$.

Portanto, $\mathbf{k}_{\mathrm{L}} \mathbf{a}=\mathbf{0 , 1 9} \mathrm{h}^{-1}$

Com uma concentração celular de $22,40.10^{6} \mathrm{cel} / \mathrm{mL}$

Assim, $Q_{02}=1,72 \cdot 10^{-18} \mathrm{~mol} \mathrm{O}_{2} /$ (cel.s) 
- $13^{\circ}$ Método Dinâmico (Novo Método Proposto - desligada a agitação e a ação em $t$ = 1 min., e, partir daí, conforme o OD foi decaindo no meio de cultura, foi ajustado, para a mesma fração, o gás na cabeça do reator e na membrana de silicone, mantendo tudo em equilíbrio, sem transferência. Foi religada a agitação e a ação em $t=23$ min. e retomada a aeração para controle a 40\% OD). O C crit está indicado no Gráfico A20.

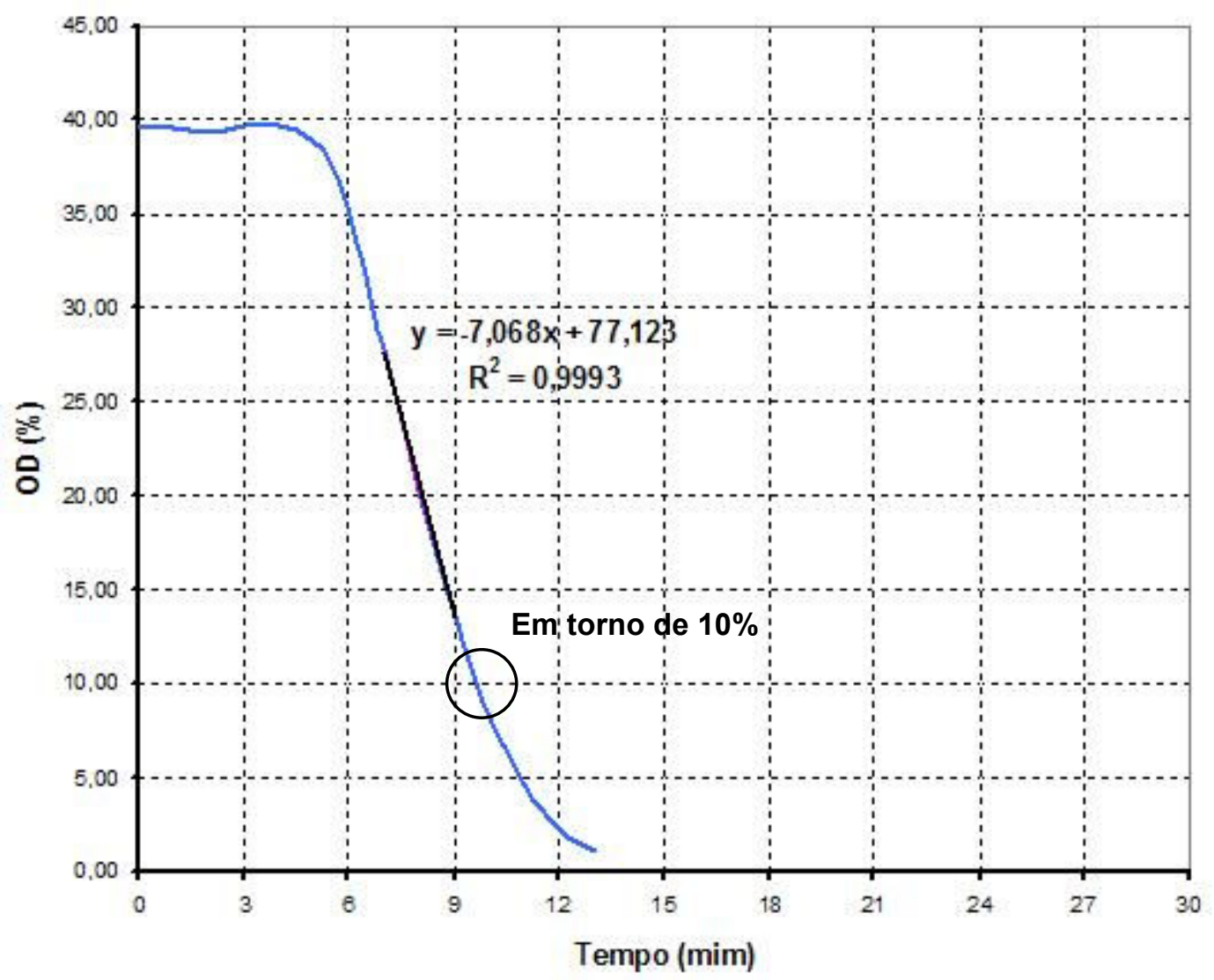

Gráfico A20 - 13a medida da OUR no Ensaio 4 (GPV) no instante 9,20 dias.

O coeficiente angular do gráfico A20 é de 7,068 OD (\%)/min.

Assim, OUR = 0,95 $\mathrm{mmol} \mathrm{O}_{2} /($ L.h $)$

Nesta OUR tem-se: $\mathrm{C}_{\mathrm{s}}=25,113 \mathrm{mgO}_{2} / \mathrm{L}$ e $\mathrm{C}_{0}=2,775 \mathrm{mgO}_{2} / \mathrm{L}$.

Portanto, $k_{L} a=1,37 h^{-1}$

Com uma concentração celular de $19,30.10^{6} \mathrm{cel} / \mathrm{mL}$

Assim, $Q_{02}=13,71 \cdot 10^{-18} \mathrm{~mol} \mathrm{O}_{2} /($ cel.s $)$ 
- $14^{\circ}$ Método Dinâmico (Novo Método Proposto - desligada a agitação e a ação em $t=2$ min., e, partir daí, conforme o OD foi decaindo no meio de cultura, foi ajustado, para a mesma fração, o gás na cabeça do reator e na membrana de silicone, mantendo tudo em equilíbrio, sem transferência. Foi religada a agitação e a ação em $t=31 \mathrm{~min}$. e retomada a aeração para controle a $40 \%$ OD). Porém, este método foi medido após controle em $80 \%$ OD. O $\mathrm{C}_{\text {crít }}$ está indicado no Gráfico A21.

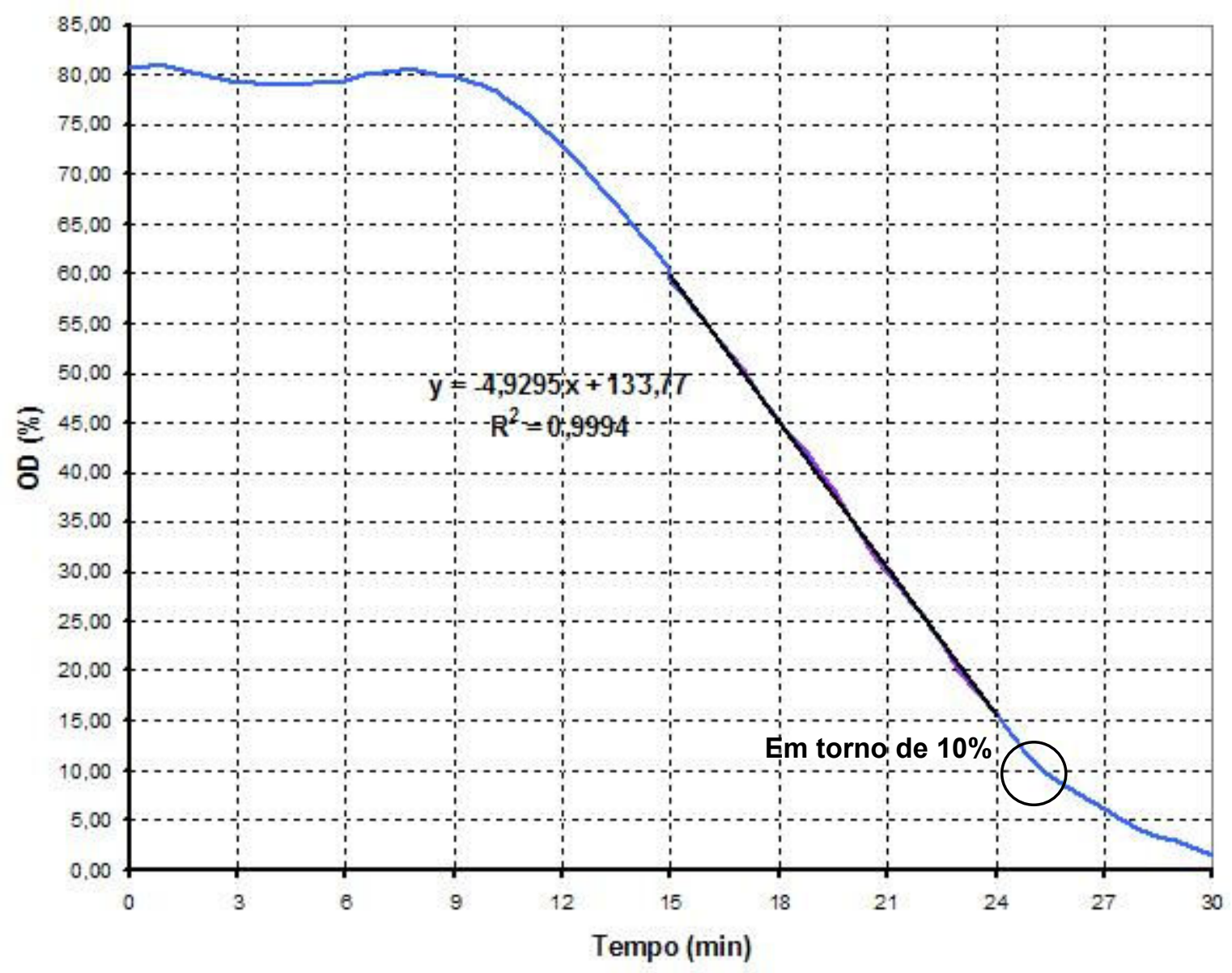

Gráfico A21 - 14ª medida da OUR no Ensaio 4 (GPV) no instante 10,02 dias.

O coeficiente angular do gráfico A21 é de 4,930 OD (\%)/min.

Assim, OUR = 0,67 $\mathrm{mmol} \mathrm{O}_{2} /($ L.h $)$

Nesta OUR tem-se: $\mathrm{C}_{\mathrm{s}}=25,113 \mathrm{mgO}_{2} / \mathrm{L}$ e $\mathrm{C}_{0}=5,609 \mathrm{mgO}_{2} / \mathrm{L}$.

Portanto, $k_{L} \mathbf{a}=1,09 \mathbf{h}^{-1}$

Com uma concentração celular de $14,50.10^{6} \mathrm{cel} / \mathrm{mL}$

Assim, $Q_{02}=12,73.10^{-18} \mathrm{~mol} \mathrm{O}_{2} /$ (cel.s) 


\section{APÊNDICE H - Medida de OUR, $k_{\mathrm{L}}$ a e Qo2 do Ensaio 5 (S2MtEGFP)}

Utilizando as equações (A7), (A9) e (A10), temos para cada Método Dinâmico efetuado:

- $1^{\circ}$ Método Dinâmico (Novo Método Proposto - desligada a agitação e a ação em t = 2 min., e, partir daí, conforme o OD foi decaindo no meio de cultura, foi ajustado, para a mesma fração, o gás na cabeça do reator e na membrana de silicone, mantendo tudo em equilíbrio, sem transferência. Foi religada a agitação e a ação em $t=19$ min. e retomada a aeração para controle a $40 \%$ OD).

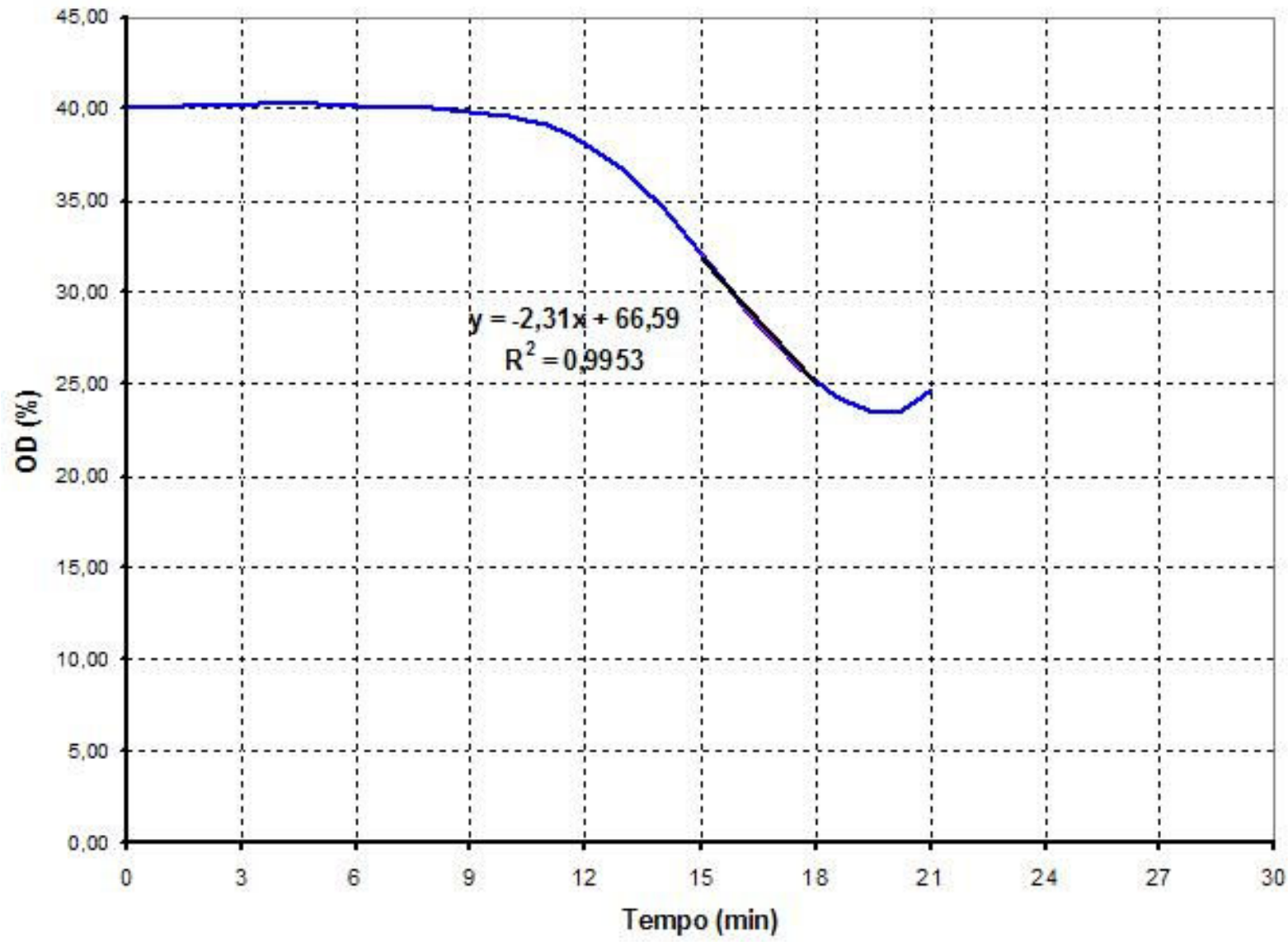

Gráfico A22 - $1^{\text {a }}$ medida da OUR no Ensaio 5 (EGFP) no instante 2,00 dias.

O coeficiente angular do gráfico A22 é de 2,310 OD (\%)/min.

Assim, OUR $=0,31 \mathrm{mmol} \mathrm{O}_{2} /($ L.h $)$

Nesta OUR tem-se: $\mathrm{C}_{\mathrm{s}}=11,301 \mathrm{mgO}_{2} / \mathrm{L} \mathrm{e} \mathrm{C}_{0}=2,802 \mathrm{mgO}_{2} / \mathrm{L}$. 
Portanto, $\mathbf{k}_{\mathrm{L}} \mathbf{a}=1,17 \mathrm{~h}^{-1}$

Com uma concentração celular de $3,36.10^{6} \mathrm{cel} / \mathrm{mL}$

Assim, $\mathbf{Q}_{02}=25,75.10^{-18} \mathrm{~mol} \mathrm{O}_{2} /($ cel.s $)$

- $2^{\circ}$ Método Dinâmico (Novo Método Proposto - desligada a agitação e a ação em $t=3$ min., e, partir daí, conforme o OD foi decaindo no meio de cultura, foi ajustado, para a mesma fração, o gás na cabeça do reator e na membrana de silicone, mantendo tudo em equilíbrio, sem transferência. Foi religada a agitação e a ação em $t=28$ min. e retomada a aeração para controle a $40 \%$ OD).

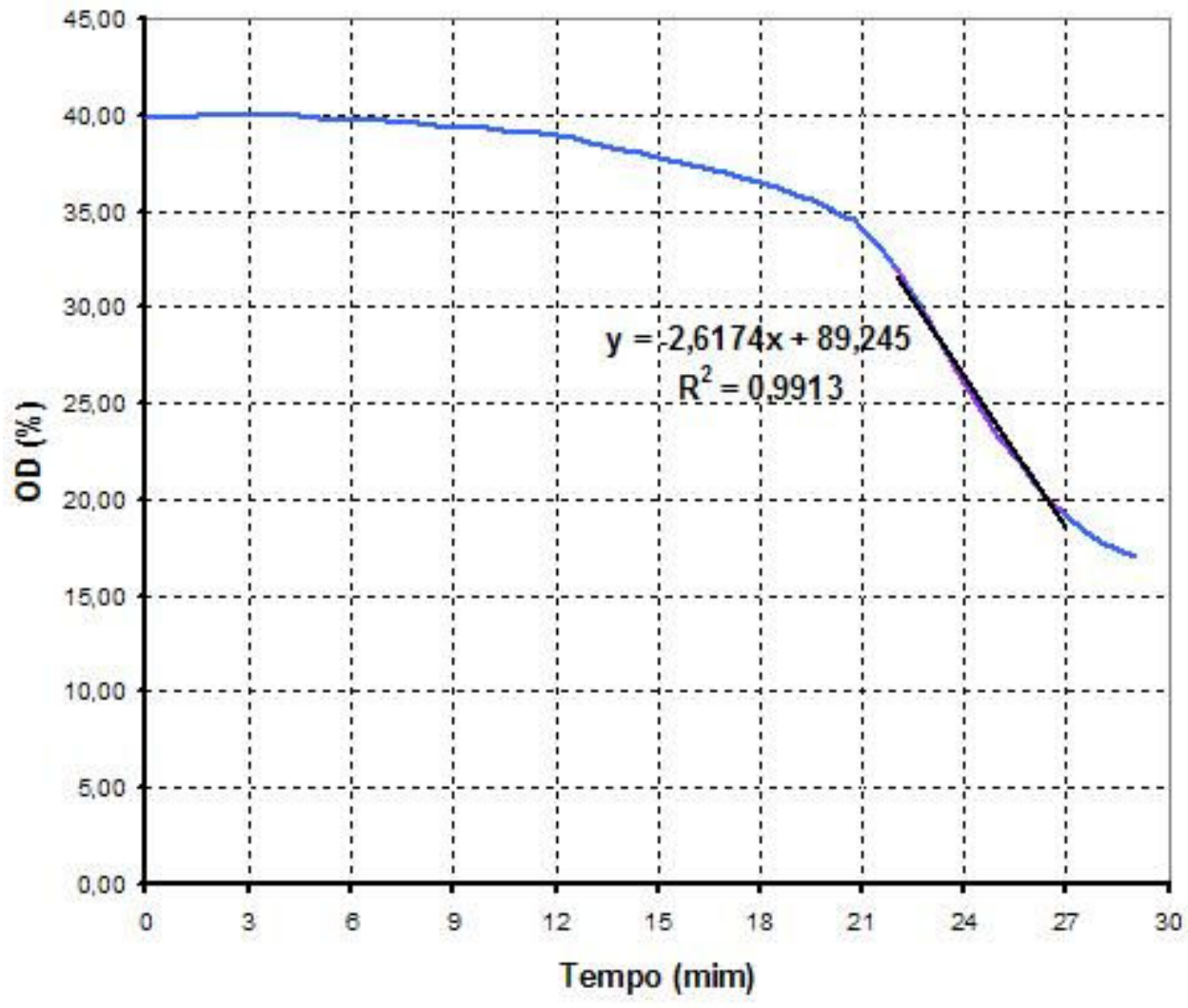

Gráfico A23 - 2 ${ }^{\mathrm{a}}$ medida da OUR no Ensaio 5 (EGFP) no instante 2,87 dias.

O coeficiente angular do gráfico A23 é de 2,617 OD (\%)/min.

Assim, OUR = 0,35 $\mathrm{mmol} \mathbf{O}_{2} /($ L.h $)$

Nesta OUR tem-se: $\mathrm{C}_{\mathrm{s}}=13,812 \mathrm{mgO}_{2} / \mathrm{L}$ e $\mathrm{C}_{0}=2,790 \mathrm{mgO}_{2} / \mathrm{L}$.

Portanto, $k_{L} a=1,02 h^{-1}$ 
Com uma concentração celular de $4,90.10^{6} \mathrm{cel} / \mathrm{mL}$

Assim, $Q_{02}=20,00 \cdot 10^{-18} \mathrm{~mol} \mathrm{O}_{2} /$ (cel.s)

- $3^{\circ}$ Método Dinâmico (Novo Método Proposto - desligada a agitação e a ação em $t=2$ min., e, partir daí, conforme o OD foi decaindo no meio de cultura, foi ajustado, para a mesma fração, o gás na cabeça do reator e na membrana de silicone, mantendo tudo em equilíbrio, sem transferência. Foi religada a agitação e a ação em $t=29$ min. e retomada a aeração para controle a $40 \%$ OD). O $\mathrm{C}_{\text {crít }}$ está indicado no Gráfico A24.

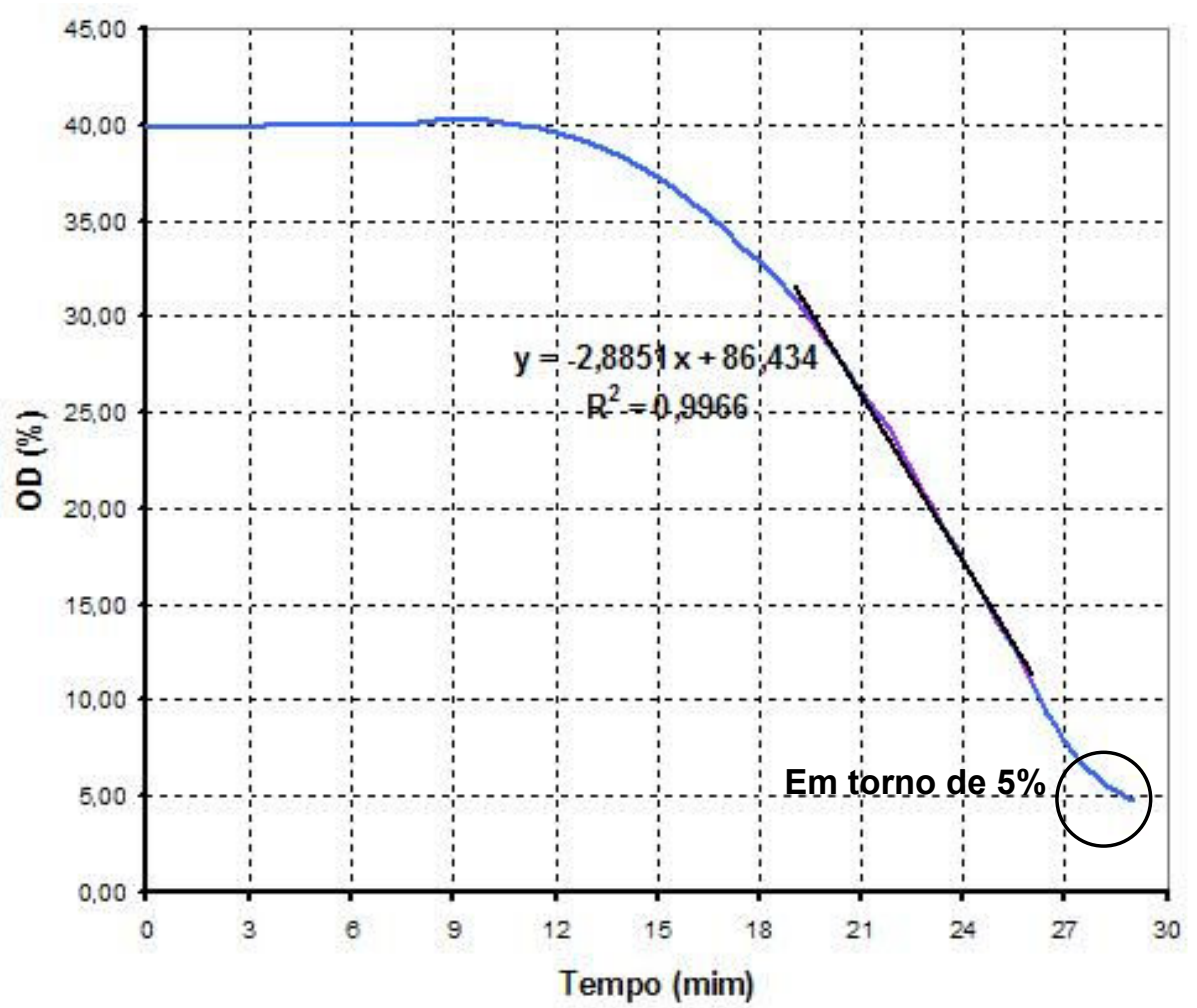

Gráfico A24 - 3a medida da OUR no Ensaio 5 (EGFP) no instante 3,25 dias.

O coeficiente angular do gráfico A24 é de 2,885 OD (\%)/min.

Assim, OUR = 0,39 $\mathrm{mmol} \mathbf{O}_{2} /($ L.h $)$

Nesta OUR tem-se: $\mathrm{C}_{\mathrm{s}}=15,068 \mathrm{mgO}_{2} / \mathrm{L} \mathrm{e} \mathrm{C}_{0}=2,796 \mathrm{mgO}_{2} / \mathrm{L}$.

Portanto, $\mathbf{k}_{\mathrm{L}} \mathbf{a}=\mathbf{1 , 0 1} \mathrm{h}^{-1}$

Com uma concentração celular de $6,00.10^{6} \mathrm{cel} / \mathrm{mL}$

Assim, $Q_{02}=18,01 \cdot 10^{-18} \mathrm{~mol} \mathrm{O}_{2} /($ cel.s $)$ 
- $4^{\circ}$ Método Dinâmico (Método Tradicional - fecha a aeração (válvula de $\mathrm{O}_{2}$ ) e a ação em $t=2$ min., despressurizou-se a linha, desligou-se a válvula de $\mathrm{N}_{2} \mathrm{e}$ a agitação após 1 minuto ( $t=3$ min.). Religou-se, em $t=20$ min., a ação, aeração e a agitação).

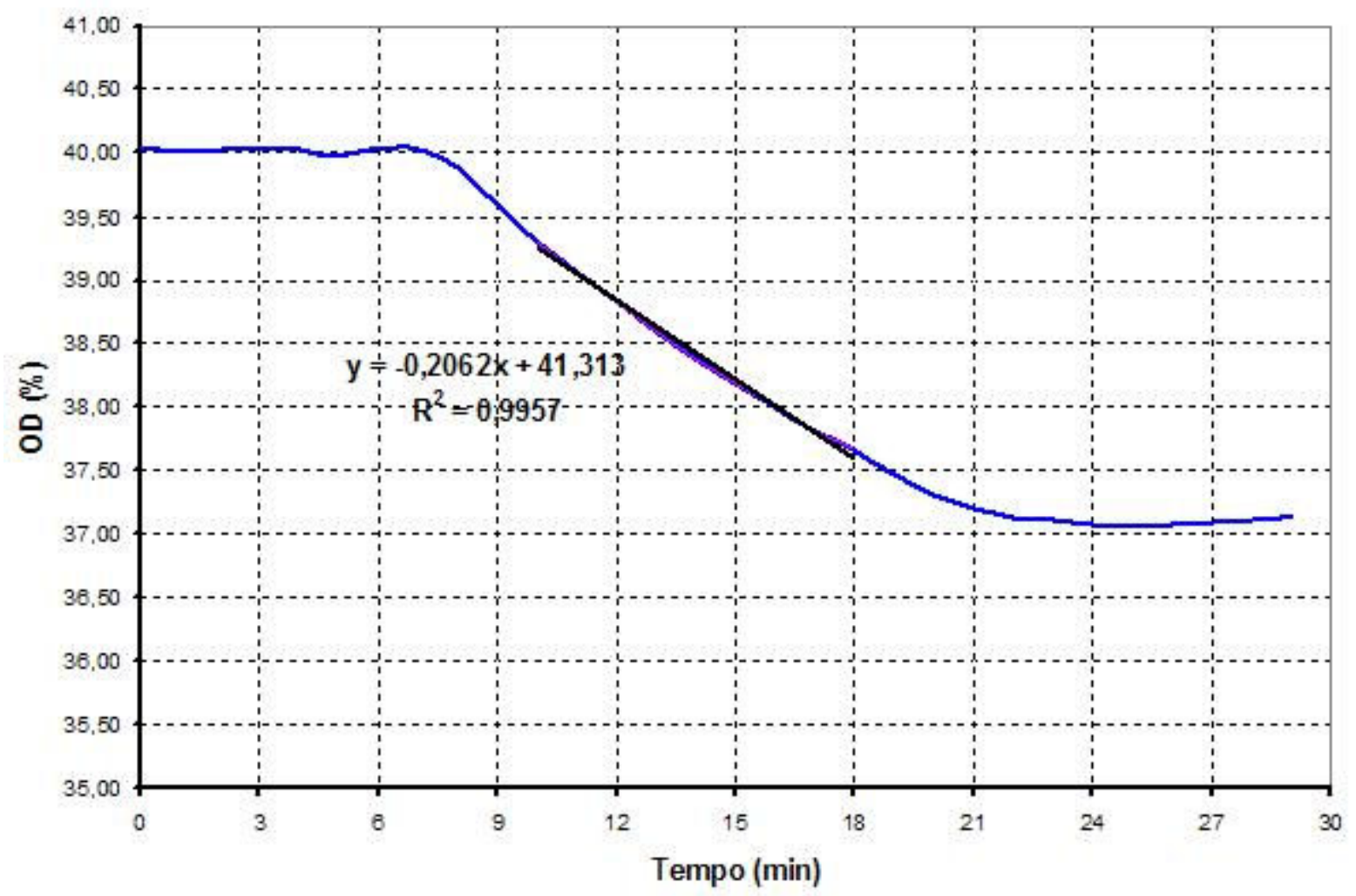

Gráfico A25 - $4^{\text {a }}$ medida da OUR no Ensaio 5 (EGFP) no instante 4,13 dias. Este gráfico está em escala diferente dos demais para ter-se a possibilidade de melhor visualização.

O coeficiente angular do gráfico A25 é de 0,206 OD (\%)/min.

Assim, OUR = 0,03 $\mathrm{mmol} \mathrm{O}_{2} /($ L.h $)$

Nesta OUR tem-se: $\mathrm{C}_{\mathrm{s}}=13,812 \mathrm{mgO}_{2} / \mathrm{L}$ e $\mathrm{C}_{0}=2,714 \mathrm{mgO}_{2} / \mathrm{L}$.

Portanto, $\mathbf{k}_{\mathrm{L}} \mathbf{a}=\mathbf{0 , 0 8} \mathbf{h}^{-1}$

Com uma concentração celular de $8,40.10^{6} \mathrm{cel} / \mathrm{mL}$

Assim, $Q_{02}=0,92.10^{-18} \mathrm{~mol} \mathrm{O}_{2} /$ (cel.s) 
- $5^{\circ}$ Método Dinâmico (Novo Método Proposto - desligada a agitação e a ação em $t$ = 2 min., e, partir daí, conforme o OD foi decaindo no meio de cultura, foi ajustado, para a mesma fração, o gás na cabeça do reator e na membrana de silicone, mantendo tudo em equilíbrio, sem transferência. Foi religada a agitação e a ação em $t=27$ min. e retomada a aeração para controle a $40 \%$ OD). O $\mathrm{C}_{\text {crit }}$ está indicado no Gráfico A26.

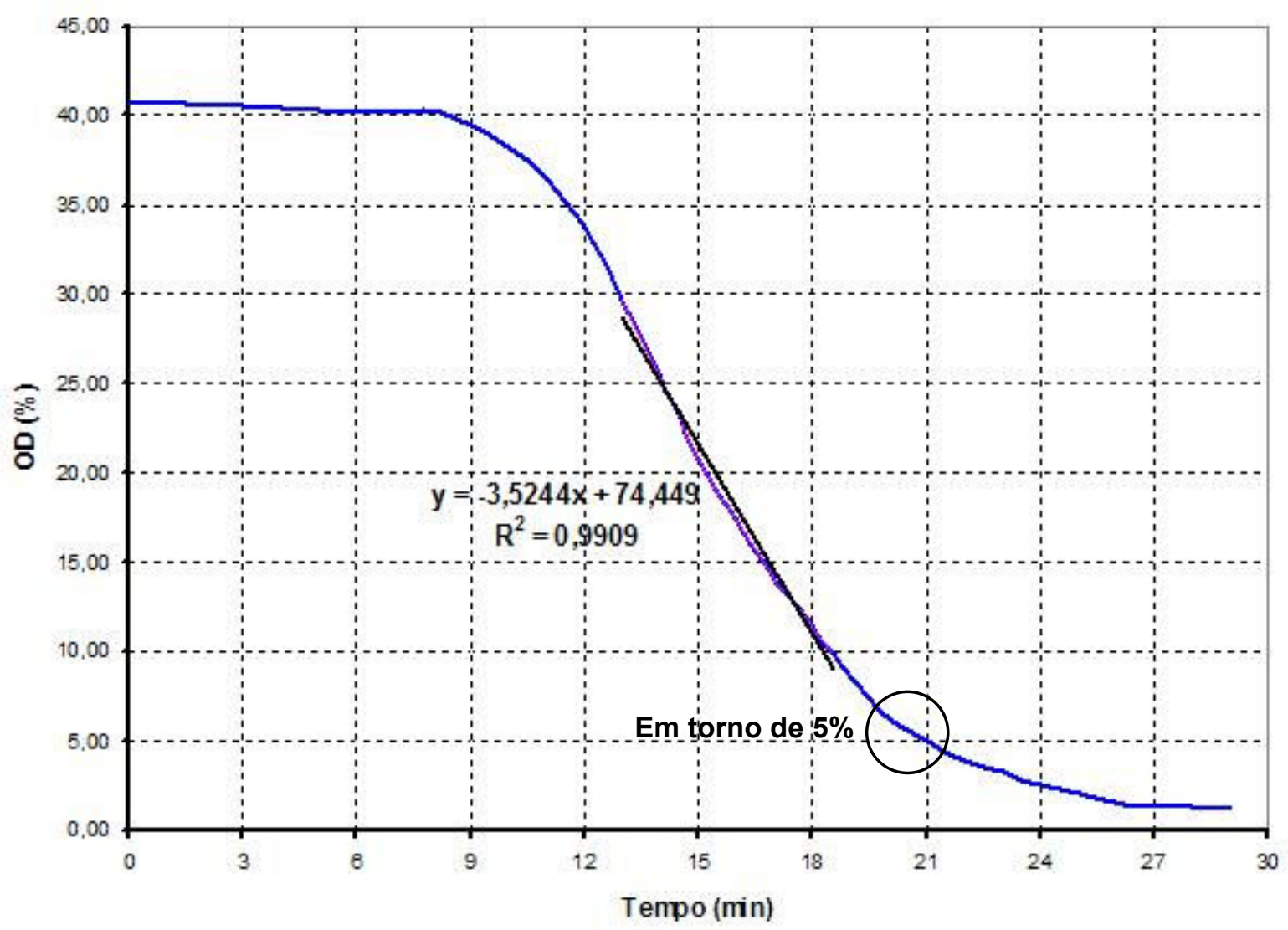

Gráfico A26 - $5^{\mathrm{a}}$ medida da OUR no Ensaio 5 (EGFP) no instante 4,68 dias.

O coeficiente angular do gráfico A26 é de 3,524 OD (\%)/min.

Assim, OUR = 0,48 $\mathrm{mmol} \mathrm{O}_{2} /($ L.h $)$

Nesta OUR tem-se: $\mathrm{C}_{\mathrm{s}}=21,346 \mathrm{mgO}_{2} / \mathrm{L}$ e $\mathrm{C}_{0}=2,818 \mathrm{mgO}_{2} / \mathrm{L}$.

Portanto, $\mathbf{k}_{\mathbf{L}} \mathbf{a}=\mathbf{0 , 8 2} \mathbf{h}^{-1}$

Com uma concentração celular de $10,15.10^{6} \mathrm{cel} / \mathrm{mL}$

Assim, $Q_{02}=13,00.10^{-18} \mathrm{~mol} \mathrm{O}_{2} /$ (cel.s) 
- $6^{\circ}$ Método Dinâmico (Novo Método Proposto - desligada a agitação e a ação em $t$ = 3 min., e, partir daí, conforme o OD foi decaindo no meio de cultura, foi ajustado, para a mesma fração, o gás na cabeça do reator e na membrana de silicone, mantendo tudo em equilíbrio, sem transferência. Foi religada a agitação e a ação em $t=50$ min. e retomada a aeração para controle a $40 \%$ OD). O $\mathrm{C}_{\text {crit }}$ está indicado no Gráfico A27.

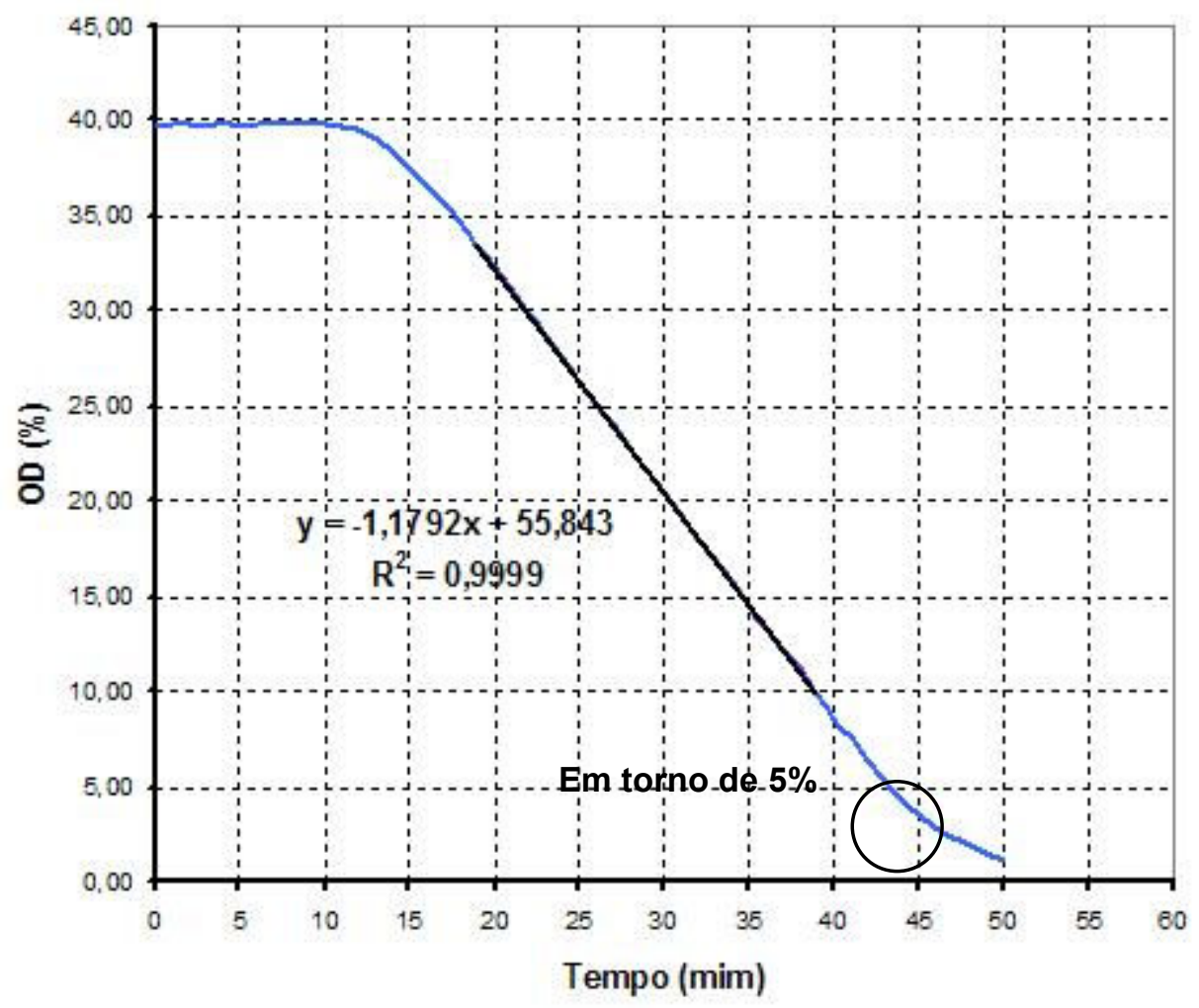

Gráfico A27 - 6a medida da OUR no Ensaio 5 (EGFP) no instante 5,34 dias.

O coeficiente angular do gráfico A27 é de 1,179 OD (\%)/min.

\section{Assim, OUR = 0,16 $\mathrm{mmol}^{\mathrm{O}_{2}} /($ L.h $)$}

Nesta OUR tem-se: $\mathrm{C}_{\mathrm{s}}=10,045 \mathrm{mgO}_{2} / \mathrm{L}$ e $\mathrm{C}_{0}=2,7833 \mathrm{mgO}_{2} / \mathrm{L}$.

Portanto, $k_{\mathrm{L}} \mathbf{a}=\mathbf{0 , 7 0} \mathbf{h}^{-1}$

Com uma concentração celular de $13,80.10^{6} \mathrm{cel} / \mathrm{mL}$

Assim, $Q_{02}=3,20.10^{-18} \mathrm{~mol} \mathrm{O}_{2} /$ (cel.s) 
- $7^{\circ}$ Método Dinâmico (Método Tradicional - fecha a aeração (válvula de $\mathrm{O}_{2}$ ) e a ação em t = 2 min., despressurizou-se a linha, desligou-se a válvula de $\mathrm{N}_{2} \mathrm{e}$ a agitação após 1 minuto ( $t=3$ min.). Religou-se, em $t=42$ min., a ação, aeração e a agitação).

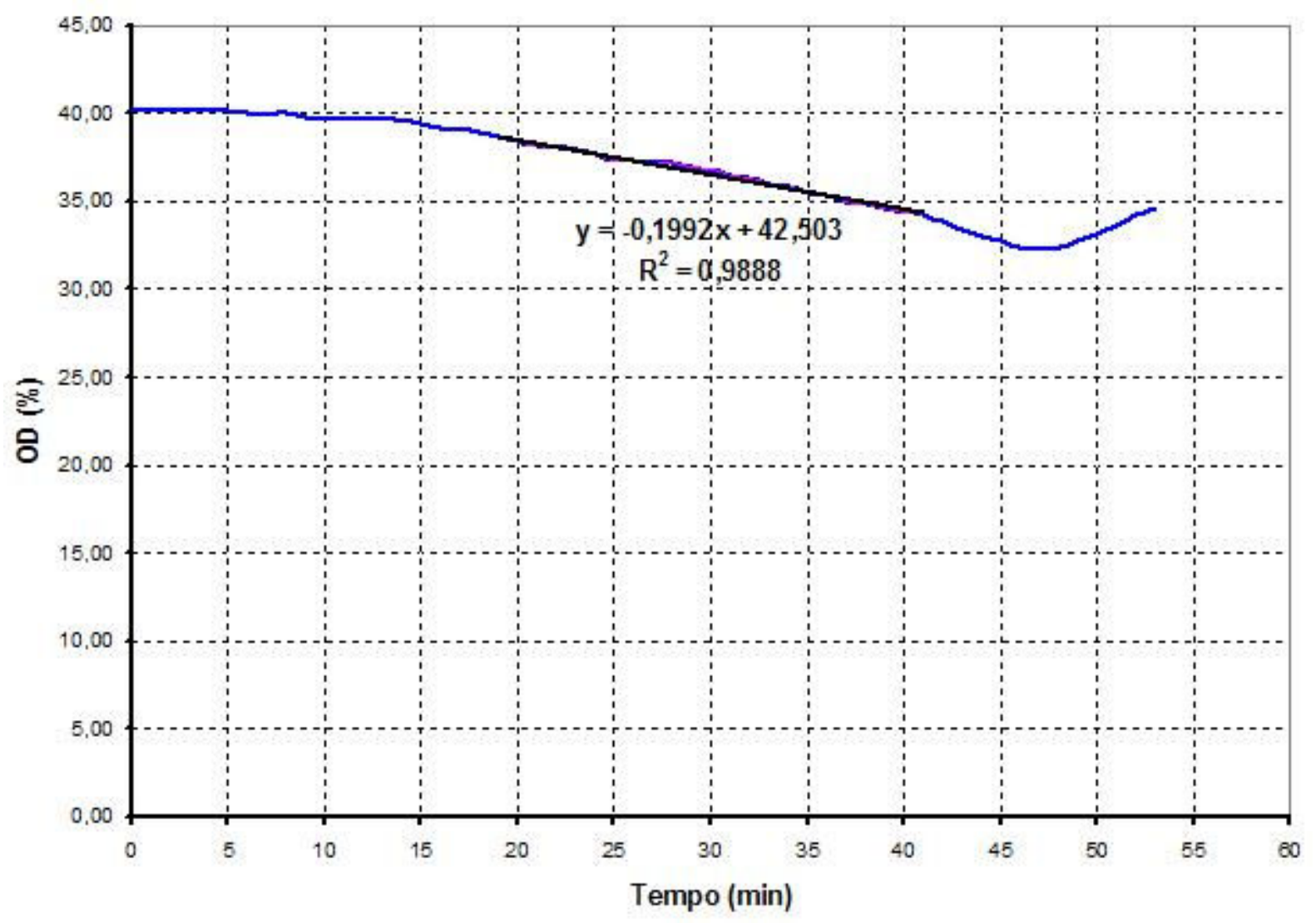

Gráfico A28 - $7^{\text {a }}$ medida da OUR no Ensaio 5 (EGFP) no instante 5,89 dias. Este gráfico está em escala diferente dos demais para ter-se a possibilidade de melhor visualização.

O coeficiente angular do gráfico A28 é de 0,199 OD (\%)/min.

Assim, OUR = 0,03 $\mathrm{mmol} \mathrm{O}_{2} /($ L.h $)$

Nesta OUR tem-se: $\mathrm{C}_{\mathrm{s}}=11,301 \mathrm{mgO}_{2} / \mathrm{L}$ e $\mathrm{C}_{0}=0,629 \mathrm{mgO}_{2} / \mathrm{L}$.

Portanto, $\mathbf{k}_{\mathrm{L}} \mathbf{a}=\mathbf{0 , 0 7} \mathbf{h}^{-1}$

Com uma concentração celular de $17,80.10^{6} \mathrm{cel} / \mathrm{mL}$

Assim, $Q_{02}=0,42.10^{-18} \mathrm{~mol} \mathrm{O}_{2} /$ (cel.s) 
- $8^{\circ}$ Método Dinâmico (Novo Método Proposto - desligada a agitação e a ação em t = 3 min., e, partir daí, conforme o OD foi decaindo no meio de cultura, foi ajustado, para a mesma fração, o gás na cabeça do reator e na membrana de silicone, mantendo tudo em equilíbrio, sem transferência. Foi religada a agitação e a ação em $t=49$ min. e retomada a aeração para controle a $40 \%$ OD). O $\mathrm{C}_{\text {crit }}$ está indicado no Gráfico A29.

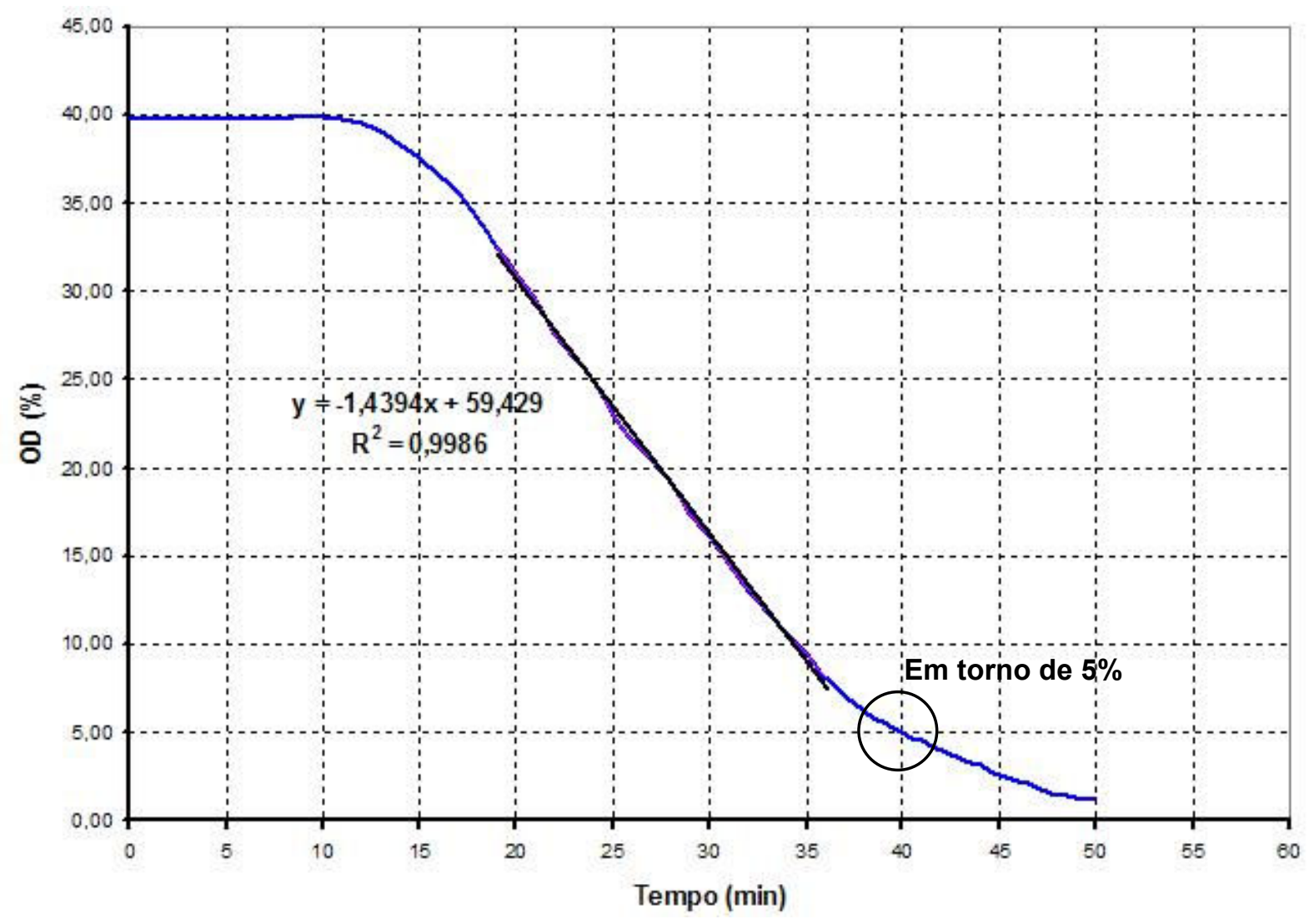

Gráfico A29 - $8^{\mathrm{a}}$ medida da OUR no Ensaio 5 (EGFP) no instante 6,73 dias.

O coeficiente angular do gráfico A29 é de 1,439 OD (\%)/min.

Assim, OUR $=0,19 \mathrm{mmol} \mathrm{O} /($ L.h $)$

Nesta OUR tem-se: $\mathrm{C}_{\mathrm{s}}=13,812 \mathrm{mgO}_{2} / \mathrm{L}$ e $\mathrm{C}_{0}=2,782 \mathrm{mgO}_{2} / \mathrm{L}$.

Portanto, $\mathbf{k}_{\mathrm{L}} \mathbf{a}=\mathbf{0 , 5 6} \mathbf{h}^{-1}$

Com uma concentração celular de $12,78.10^{6} \mathrm{cel} / \mathrm{mL}$

Assim, $Q_{02}=4,22.10^{-18} \mathrm{~mol} \mathrm{O}_{2} /($ cel.s $)$ 


\section{APÊNDICE I - Medida de OUR, kLa e Qo2 do Ensaio 6 (S2AcHBsAgHy)}

Utilizando as equações (A7), (A9) e (A10), temos para cada Método Dinâmico efetuado:

- $1^{\circ}$ Método Dinâmico (Método Tradicional - fecha a aeração (válvula de $\mathrm{O}_{2}$ ) e a ação em t = 2 min., despressurizou-se a linha, desligou-se a válvula de $\mathrm{N}_{2} \mathrm{e}$ a agitação após 1 minuto ( $t=3$ min.). Religou-se, em $t=22$ min., a ação, aeração e a agitação).

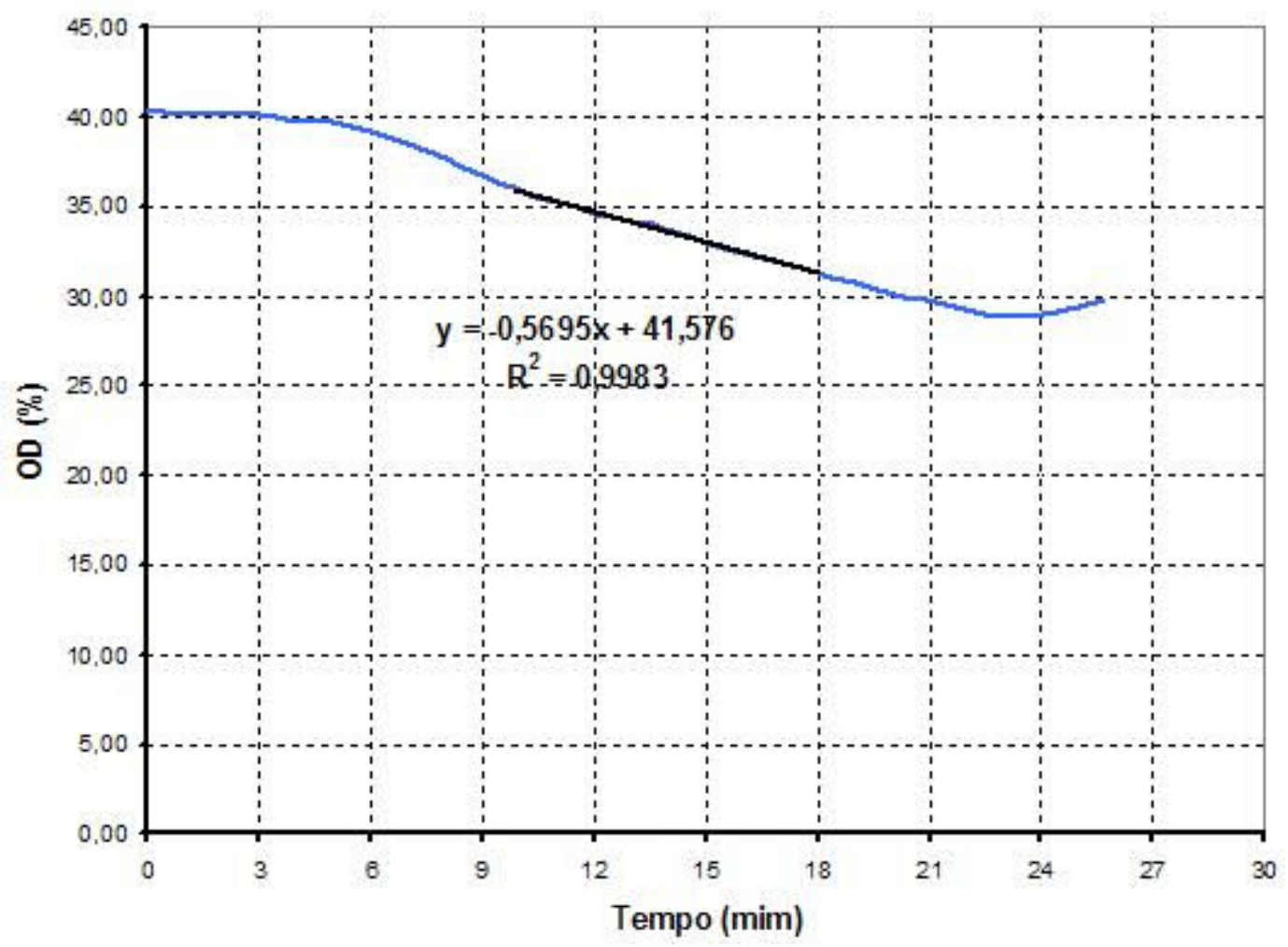

Gráfico A30 - 1ª medida da OUR no Ensaio 6 (HBsAg) no instante 4,95 dias.

O coeficiente angular do gráfico A30 é de 0,570 OD (\%)/min.

Assim, OUR = 0,08 $\mathrm{mmol}^{\mathrm{O}_{2} /(\text { L.h })}$

Nesta OUR tem-se: $\mathrm{C}_{\mathrm{s}}=8,789 \mathrm{mgO}_{2} / \mathrm{L}$ e $\mathrm{C}_{0}=2,802 \mathrm{mgO}_{2} / \mathrm{L}$.

Portanto, $k_{L} \mathbf{a}=0,41 h^{-1}$

Com uma concentração celular de $1,20.10^{6} \mathrm{cel} / \mathrm{mL}$

Assim, $Q_{02}=17,77.10^{-18} \mathrm{~mol} \mathrm{O}_{2} /($ cel.s $)$ 
- $2^{\circ}$ Método Dinâmico (Método Tradicional - fecha a aeração (válvula de $\mathrm{O}_{2}$ ) e a ação em $t$ = 6 min., despressurizou-se a linha, desligou-se a válvula de $\mathrm{N}_{2} \mathrm{e}$ a agitação após 1 minuto ( $t=7$ min.). Religou-se, em $t=25$ min., a ação, aeração e a agitação).

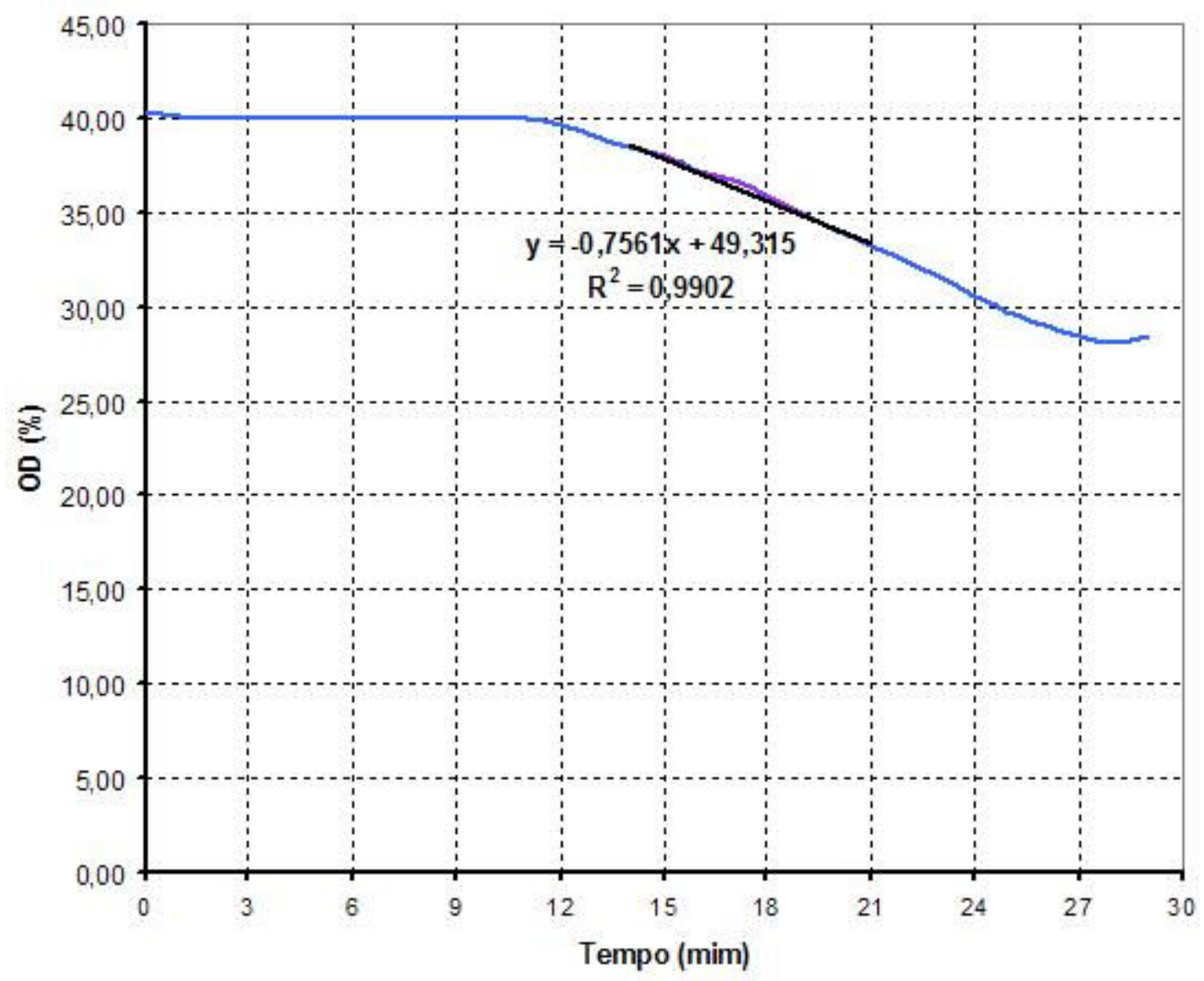

Gráfico A31 - $2^{\mathrm{a}}$ medida da OUR no Ensaio $6(\mathrm{HBsAg})$ no instante 6,03 dias.

O coeficiente angular do gráfico A31 é de 0,756 OD (\%)/min.

Assim, OUR = 0,10 $\mathrm{mmol} \mathrm{O}_{2} /($ L.h $)$

Nesta OUR tem-se: $\mathrm{C}_{\mathrm{s}}=11,301 \mathrm{mgO}_{2} / \mathrm{L}$ e $\mathrm{C}_{0}=2,762 \mathrm{mgO}_{2} / \mathrm{L}$.

Portanto, $\mathbf{k}_{\mathrm{L}} \mathbf{a}=\mathbf{0 , 3 8} \mathrm{h}^{-1}$

Com uma concentração celular de $2,60.10^{6} \mathrm{cel} / \mathrm{mL}$

Assim, $Q_{02}=10,89 \cdot 10^{-18} \mathrm{~mol} \mathrm{O}_{2} /($ cel.s $)$ 
- $3^{\circ}$ Método Dinâmico (Novo Método Proposto - desligada a agitação e a ação em $t$ = 1 min., e, partir daí, conforme o OD foi decaindo no meio de cultura, foi ajustado, para a mesma fração, o gás na cabeça do reator e na membrana de silicone, mantendo tudo em equilíbrio, sem transferência. Foi religada a agitação e a ação em $t=24$ min. e retomada a aeração para controle a $40 \%$ OD). O $\mathrm{C}_{\text {crit }}$ está indicado no Gráfico A32.

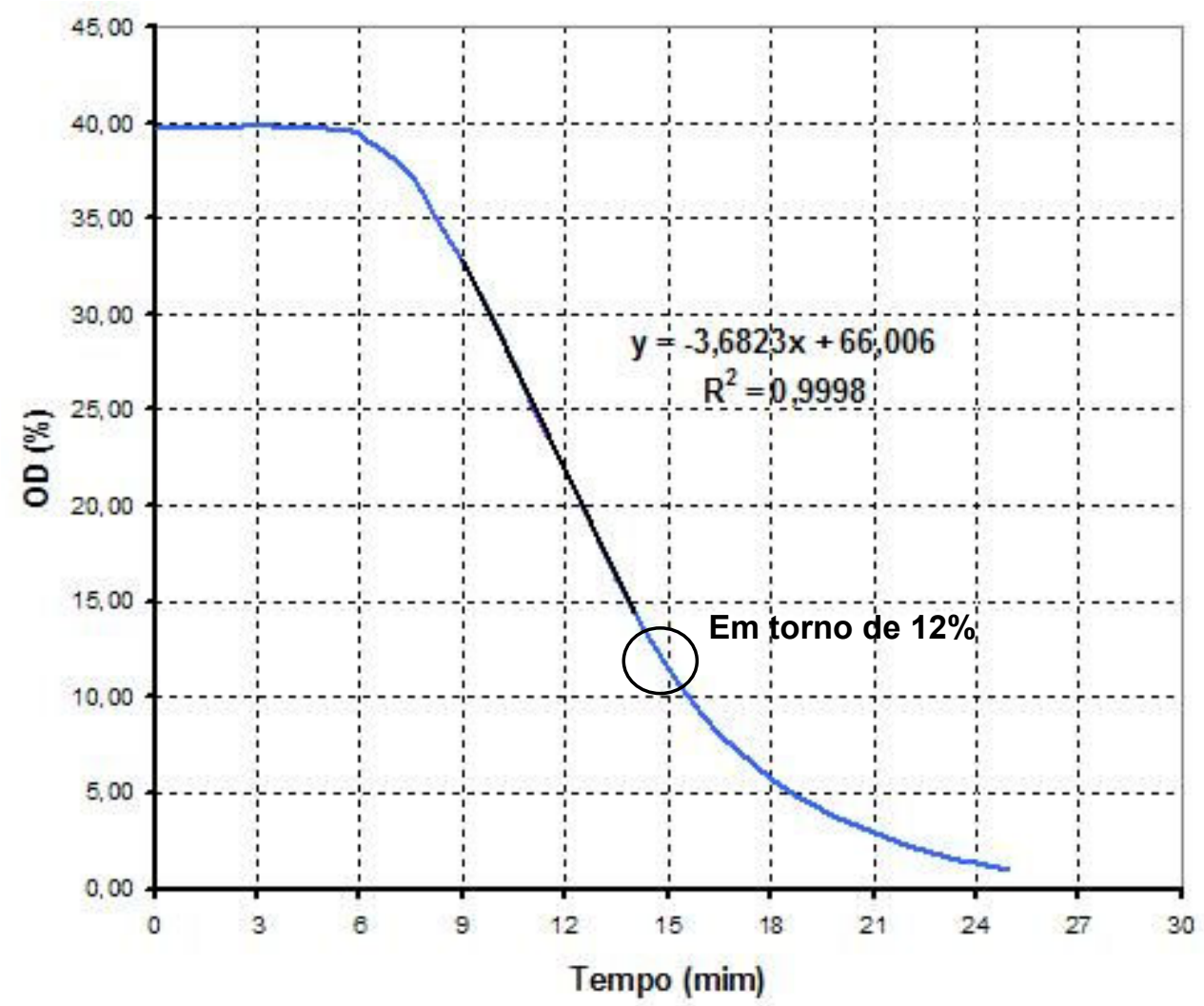

Gráfico A32 - 3a medida da OUR no Ensaio 6 (HBsAg) no instante 7,03 dias.

O coeficiente angular do gráfico A32 é de 3,682 OD (\%)/min.

\section{Assim, OUR $=0,50 \mathrm{mmol} \mathrm{O}_{2} /($ L.h $)$}

Nesta OUR tem-se: $\mathrm{C}_{\mathrm{s}}=11,301 \mathrm{mgO}_{2} / \mathrm{L} \mathrm{e} \mathrm{C}_{0}=2,766 \mathrm{mgO}_{2} / \mathrm{L}$.

Portanto, $k_{L} a=1,86 h^{-1}$

Com uma concentração celular de $4,10.10^{6} \mathrm{cel} / \mathrm{mL}$

Assim, $Q_{02}=33,63.10^{-18} \mathrm{~mol} \mathrm{O}_{2} /($ cel.s $)$ 
- $4^{\circ}$ Método Dinâmico (Método Tradicional - fecha a aeração (válvula de $\mathrm{O}_{2}$ ) e a ação em t = 2 min., despressurizou-se a linha, desligou-se a válvula de $\mathrm{N}_{2} \mathrm{e}$ a agitação após 1 minuto ( $t=3$ min.). Religou-se, em $t=53$ min., a ação, aeração e a agitação). O C crit está indicado no Gráfico A33.

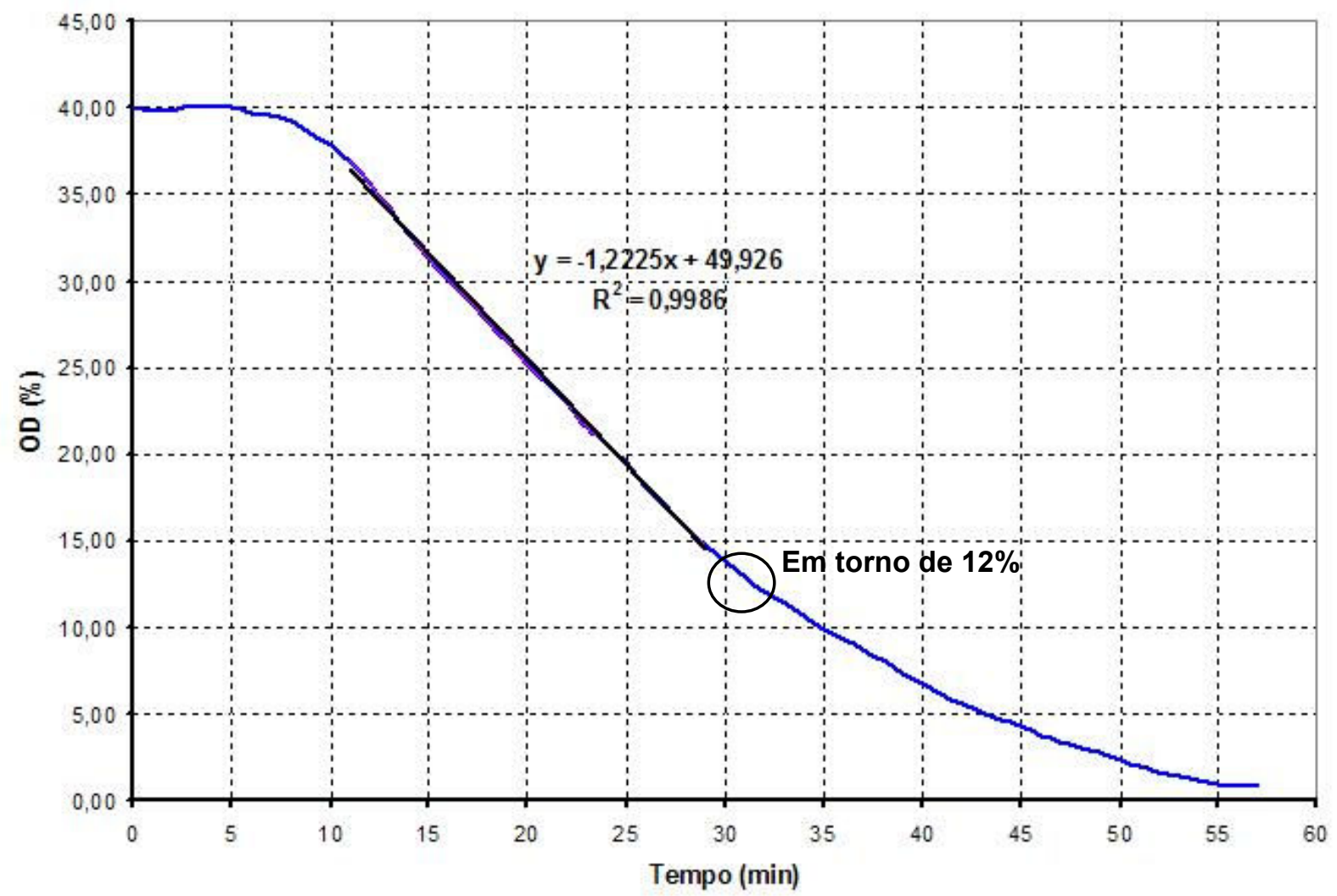

Gráfico A33 - 4a medida da OUR no Ensaio 6 (HBsAg) no instante 7,97 dias.

O coeficiente angular do gráfico A33 é de 1,223 OD (\%)/min.

Assim, OUR = 0,17 $\mathrm{mmol} \mathrm{O}_{2} /($ L.h $)$

Nesta OUR tem-se: $\mathrm{C}_{\mathrm{s}}=13,812 \mathrm{mgO}_{2} / \mathrm{L}$ e $\mathrm{C}_{0}=2,744 \mathrm{mgO}_{2} / \mathrm{L}$.

Portanto, $k_{\mathrm{L}} \mathbf{a}=\mathbf{0 , 4 8} \mathrm{h}^{-1}$

Com uma concentração celular de $6,60.10^{6} \mathrm{cel} / \mathrm{mL}$

Assim, $Q_{02}=6,94.10^{-18} \mathrm{~mol} \mathrm{O}_{2} /$ (cel.s) 
- $5^{\circ}$ Método Dinâmico (Novo Método Proposto - desligada a agitação e a ação em $t$ = 2 min., e, partir daí, conforme o OD foi decaindo no meio de cultura, foi ajustado, para a mesma fração, o gás na cabeça do reator e na membrana de silicone, mantendo tudo em equilíbrio, sem transferência. Foi religada a agitação e a ação em $t=22$ min. e retomada a aeração para controle a $40 \%$ OD). O $\mathrm{C}_{\text {crit }}$ está indicado no Gráfico A34.

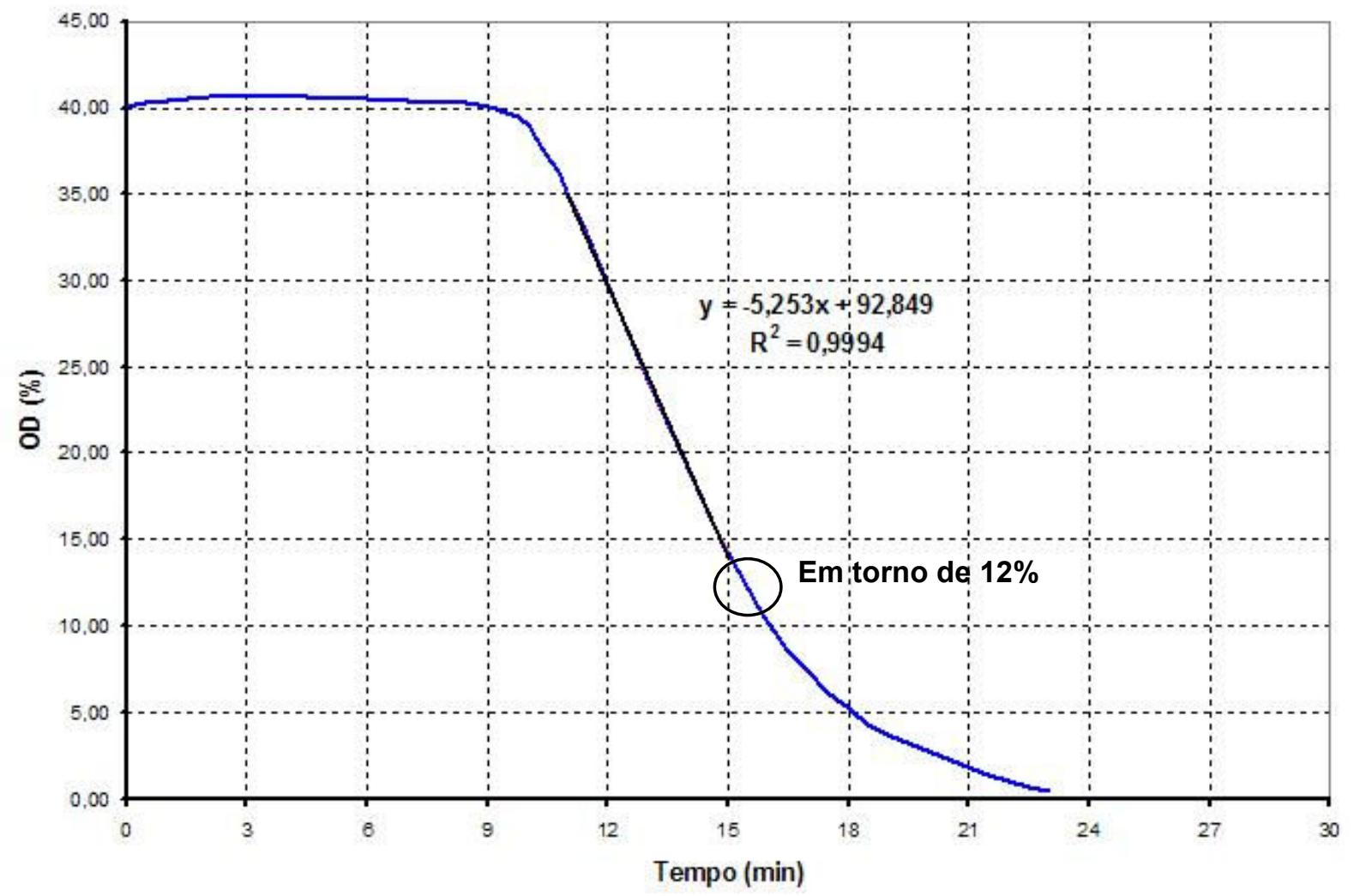

Gráfico A34 - 5a medida da OUR no Ensaio 6 (HBsAg) no instante 8,87 dias.

O coeficiente angular do gráfico A34 é de 5,253 OD (\%)/min.

Assim, OUR = 0,71 $\mathrm{mmol} \mathrm{O}_{2} /($ L.h $)$

Nesta OUR tem-se: $\mathrm{C}_{\mathrm{s}}=16,323 \mathrm{mgO}_{2} / \mathrm{L}$ e $\mathrm{C}_{0}=2,827 \mathrm{mgO}_{2} / \mathrm{L}$.

Portanto, $k_{\mathrm{L}} \mathbf{a}=1,68 \mathrm{~h}^{-1}$

Com uma concentração celular de $10,40.10^{6} \mathrm{cel} / \mathrm{mL}$

Assim, $Q_{02}=18,91 \cdot 10^{-18} \mathrm{~mol} \mathrm{O}_{2} /($ cel.s $)$ 
- $6^{\circ}$ Método Dinâmico (Método Tradicional - fecha a aeração (válvula de $\mathrm{O}_{2}$ ) e a ação em $t$ = 3 min., despressurizou-se a linha, desligou-se a válvula de $\mathrm{N}_{2} \mathrm{e}$ a agitação após 1 minuto ( $\mathrm{t}=4 \mathrm{~min}$.). Religou-se, em $\mathrm{t}=37 \mathrm{~min}$., a ação, aeração e a agitação). O $\mathrm{C}_{\text {crit }}$ está indicado no Gráfico A35.

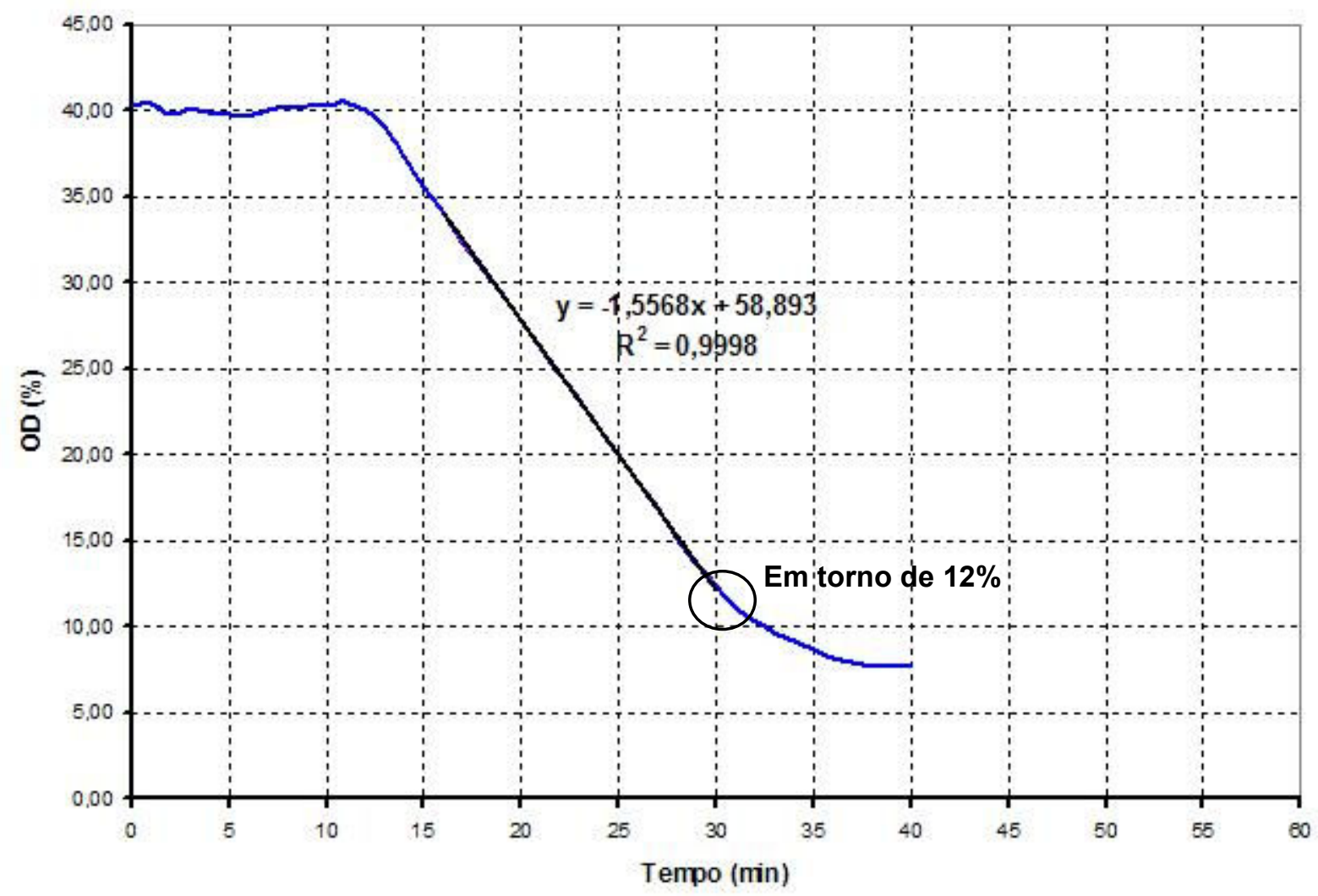

Gráfico A35 - 6 ${ }^{\mathrm{a}}$ medida da OUR no Ensaio 6 (HBsAg) no instante 9,91 dias.

O coeficiente angular do gráfico A35 é de 1,557 OD (\%)/min.

Assim, OUR = 0,21 $\mathrm{mmol} \mathrm{O}_{2} /($ L.h $)$

Nesta OUR tem-se: $\mathrm{C}_{\mathrm{s}}=18,834 \mathrm{mgO}_{2} / \mathrm{L}$ e $\mathrm{C}_{0}=2,776 \mathrm{mgO}_{2} / \mathrm{L}$.

Portanto, $\mathbf{k}_{\mathrm{L}} \mathbf{a}=\mathbf{0 , 4 2} \mathbf{h}^{-1}$

Com uma concentração celular de $14,20.10^{6} \mathrm{cel} / \mathrm{mL}$

Assim, $Q_{02}=4,12.10^{-18} \mathrm{~mol} \mathrm{O}_{2} /$ (cel.s) 
- $7^{\circ}$ Método Dinâmico (Novo Método Proposto - desligada a agitação e a ação em $t$ = 1 min., e, partir daí, conforme o OD foi decaindo no meio de cultura, foi ajustado, para a mesma fração, o gás na cabeça do reator e na membrana de silicone, mantendo tudo em equilíbrio, sem transferência. Foi religada a agitação e a ação em $t=18$ min. e retomada a aeração para controle a $40 \%$ OD). O $\mathrm{C}_{\text {crit }}$ está indicado no Gráfico A36.

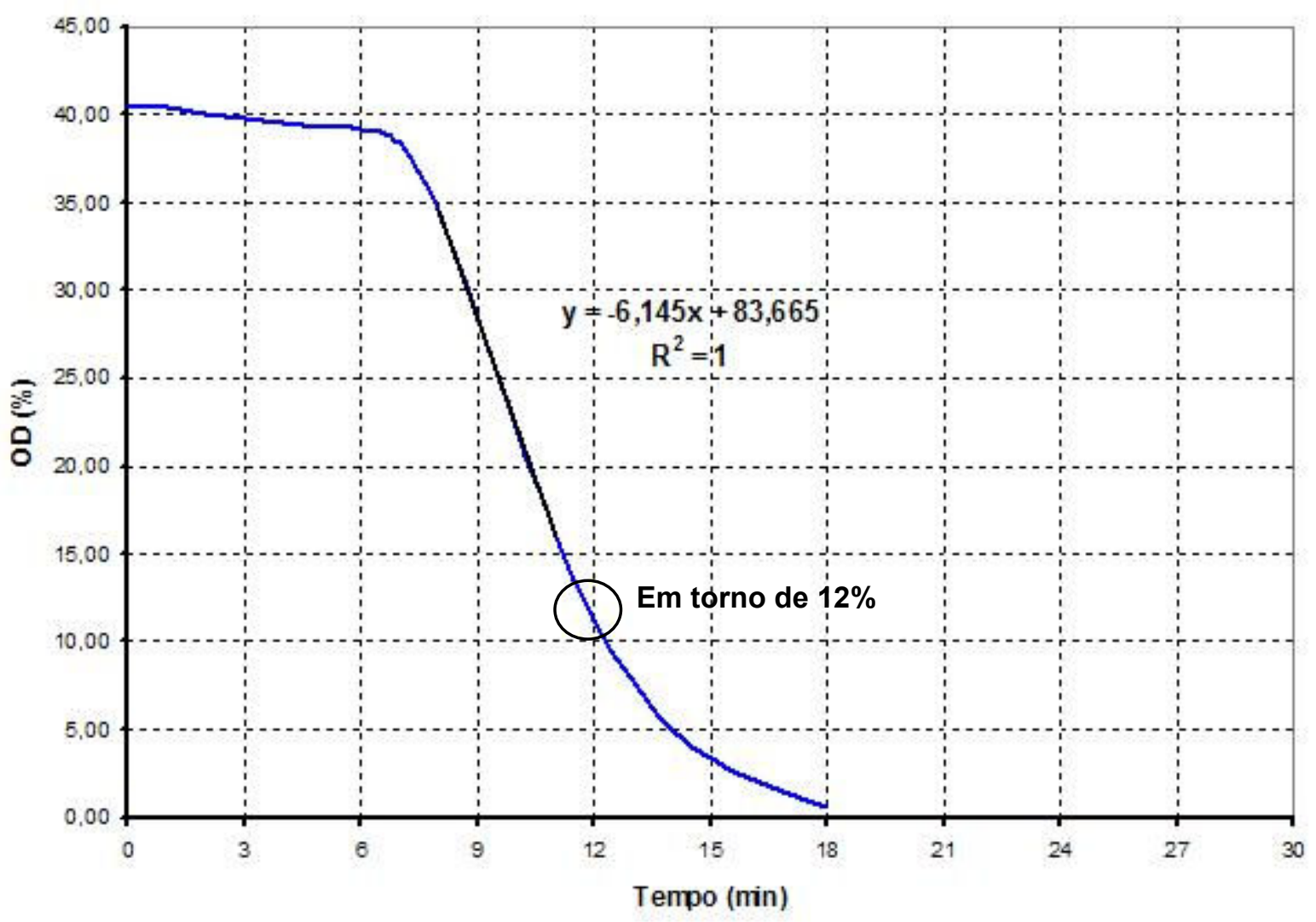

Gráfico A36 - $7^{\mathrm{a}}$ medida da OUR no Ensaio 6 (HBsAg) no instante 10,89 dias.

O coeficiente angular do gráfico A36 é de 6,145 OD (\%)/min.

Assim, OUR = 0,83 $\mathrm{mmol} \mathbf{O}_{2} /($ L.h $)$

Nesta OUR tem-se: $\mathrm{C}_{\mathrm{s}}=20,090 \mathrm{mgO}_{2} / \mathrm{L}$ e $\mathrm{C}_{0}=2,820 \mathrm{mgO}_{2} / \mathrm{L}$.

Portanto, $k_{\mathrm{L}} \mathbf{a}=1,55 \mathrm{~h}^{-1}$

Com uma concentração celular de $16,60.10^{6} \mathrm{cel} / \mathrm{mL}$

Assim, $Q_{02}=13,86.10^{-18} \mathrm{~mol} \mathrm{O}_{2} /$ (cel.s) 